Journal of the Scientific Agricultural Society of Finland

Vol. 55: 183-301, 1983

Maataloustieteellinen Aikakauskirja

\title{
POTATO VIRUSES IN FINLAND AND THEIR IDENTIFICATION
}

Selostus: Suomessa esiintyvät perunavirukset ja niiden märittäminen

\author{
AARNE KURPPA \\ Department of Plant Pathology \\ University of Helsinki \\ SF-00710 Helsinki 71, Finland
}

ACADEMIC DISSERTATION

TO BE PRESENTED, WITH THE PERMISSION OF THE

FACULTY OF AGRICULTURE AND FORESTRY OF THE

UNIVERSITY OF HELSINKI, FOR PUBLIC CRITICISM IN

AUditorium VIIKKI B 2 ON NOVEMber 4, 1983 AT 12

O'CLOCK.

\section{Maatalouden tutkimuskeskus \\ Kirjasto.}





\section{Preface}

This study was carried out at the Department of Plant Pathology of the University of Helsinki. I wish to express my sincere gratitude to my teacher, Professor Eeva Tapio, the Head of the Department, for the support she has given me in my work over a long period of time and for her constructive criticism of the manuscript.

Special thanks are due to the personnel of the Department of Plant Pathology, especially to Mr. Pentti Heinänen, Mr. Tauno Koivunen and Mrs. Pirkko Korhonen and to my excellent student assistants Mrs. Marianne Heinonen M.Sc. and Mrs. Pirkko Martikainen M.Sc. for their invaluable technical help throughout this study.

I also wish to thank Miss Heather MacKenzie B.Sc. for linguistic revision of the English text. Special thanks are also due to Mrs. Airi Visuri for typing the manuscript and Mrs. Kerttu Lehtinen for drawing the numerous figures.

The Seed Potato Center, the State Seed Testing Station and the Finnish plant breeding stations and potato processing companies are thanked for providing research material.

This study was supported by grants from the Finnish Cultural Foundation and the Society of Agronomists.

I am grateful to the Scientific Agricultural Society of Finland for including this study in their series of publications.

Finally, I wish to express my sincere thanks and gratitude to my wife for her great interest and patience during my work.

Helsinki, May 1983

Aarne Kurppa 



\section{CONTENTS}

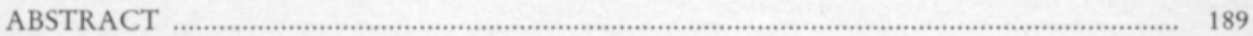

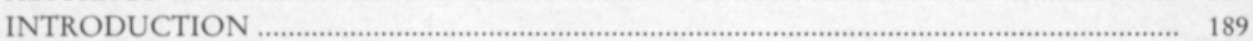

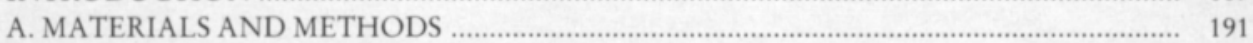

1. Isolation of the viruses and their biological properties .................................................. 191

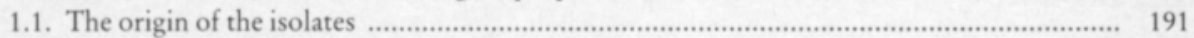

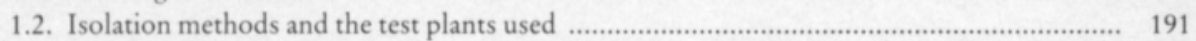

1.3. Thermal inactivation point and dilution end point determination ..................................... 194

1.4. Virus preservation and their propagation for purification .................................................. 194

2. Electron microscopy ................................................................................................. 195

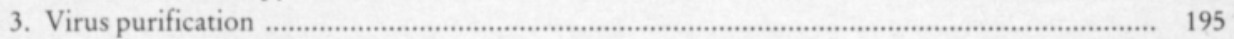

4. Antiserum production and the properties of the antisera …................................................... 196

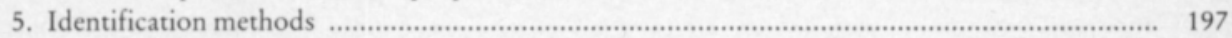

5.1. Chloroplast agglutination, microprecipitin and cut leaf tests .......................................... 197

5.2. Gel diffusion tests ................................................................................................. 197

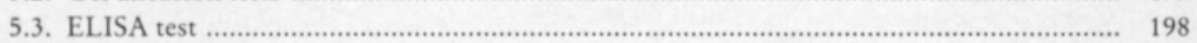

6. Field experiments and statistical analysis of the results ...................................................... 199

B. THE VIRUSES AND THE VIRUS STRAINS FOUND IN FINLAND AND THEIR

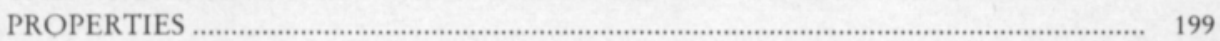

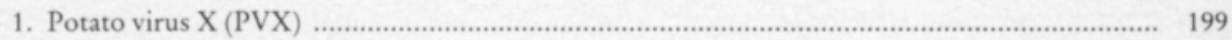

1.1. Symptoms in potatoes and test plants and virus strain classification .................................. 200

1.2. Sap properties and virus purification ....................................................................... 202

1.2.1. Thermal inactivation point and dilution end point .............................................. 202

1.2.2. Virus purification ........................................................................................ 203

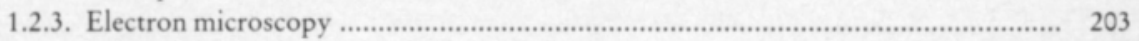

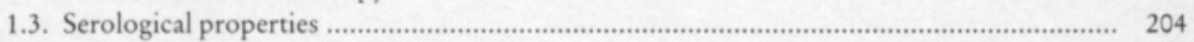

1.3.1. Homologous titers of the antisera ................................................................ 204

1.3.2. Heterologous titers of the antisera ............................................................... 205

1.3.3. Immunogenesis of the degraded antigen ............................................................ 205

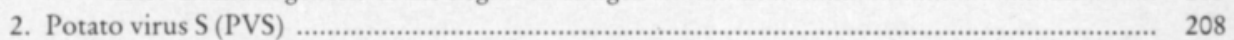

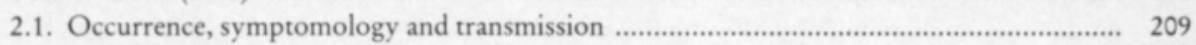

2.2. Symptoms in test plants and isolate classification ......................................................... 210

2.3. Sap properties and virus purification ...................................................................... $\quad 212$

2.3.1. Thermal inactivation point and dilution end point ............................................ 212

2.3.2. Electron microscopy and purification ............................................................ 213

2.4. Serolocical properties ............................................................................................ 213

2.4.1. Homologous titers of the antisera .................................................................. 213

2.4.2. Heterologous titers of the antisera ................................................................... 213

2.4.3. Immunogenesis of the degraded antigen .......................................................... 215

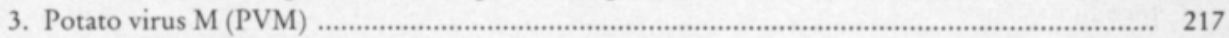

3.1. Occurrence and symptomology in potatoes ……...................................................... 218

3.2. Symptoms in test plants and isolate classification ....................................................... 218

3.3. Sap properties and virus purification ...................................................................... 219 
3.4. Serological properties

3.4.1. Homologous titers of the antisera ........................................................................ 220

3.4.2. Heterologous titers of the antisera ........................................................................... 220

3.4.3. Immunogenesis of the degraded antigen ................................................................ 221

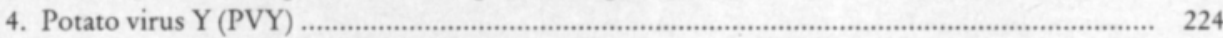

4.1. Potato symptomology and virus transmission ............................................................ 225

4.2. Symptoms in test plants and strain classification ........................................................ 226

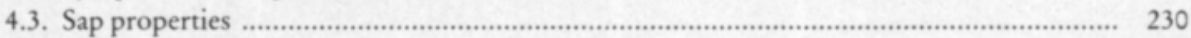

4.4. Virus purification ........................................................................................................... 231

4.5. Serological properties ................................................................................................. 232

4.5.1. Homologous titers of the antisera ................................................................... 232

4.5.2. Heterologous titers of the antisera ....................................................................... 232

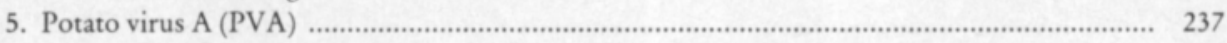

5.1. Properties of the virus isolates that occur in Finland ..................................................... 237

5.1.1. Occurrence and symptomology in potatoes and test plants ................................ 237

5.1.2. Sap properties .................................................................................................. 238

5.1.3. Virus purification and serological identification ............................................... 238

6. Potato leaf roll virus (PLRV) ............................................................................................. 240

6.1. Occurrence in Finland ............................................................................................... 240

6.2. Properties of the virus isolates ......................................................................................... 241

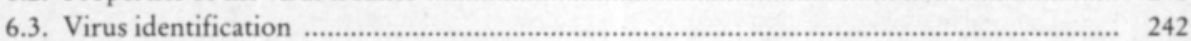

6.4. Virus purification and particle properties ........................................................................ 243

7. Tobacco rattle virus (TRV) ................................................................................................... 246

7.1. Symptoms caused by the isolates occurring in Finland ................................................ 248

7.2. Sap properties and virus purification ......................................................................... 248

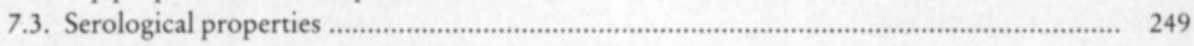

C. DIFFERENT METHODS OF IDENTIFYING POTATO VIRUSES …....................................253

1. Methodological developments in virus identification .......................................................... 253

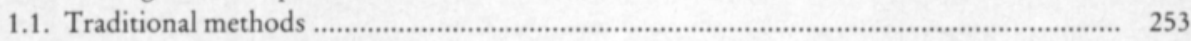

1.2. Labelled antibody techniques ..................................................................................... 254

2. The suitability of these methods for potato virus identification as tested in Finland .................. 255

2.1. Chloroplast agglutination methods and the cut leaf method ........................................... 255

2.2. Agar gel diffusion methods ......................................................................................... 256

2.2.1. Double diffusion test ............................................................................................ 256

2.2.2. Single diffusion test ............................................................................................. 257

2.2.3. Comparisons between the gel diffusion and the agglutination methods .................. 258

2.3. ELISA method ........................................................................................................ 260

2.3.1. Reaction specificity of different antibody preparates ............................................ 260

2.3.2. Test sensitivity .................................................................................................... 264

2.3.3. Relationships between the viruses and the virus isolates as determined with the ELISA test ................................................................................................. 265

2.3.4. Virus identification in potato samples at different developmental stages ................. 269

2.3.4.1. Identification of known isolates of PVX, PVM, PVS and PVY with indigenous test reagents

2.3.4.2. Identification of known isolates of PVY, PVA and PLRV with foreign test reagents

2.3.4.3. Identification of unknown viruses in naturally infected potatoes ................ 277

2.3.5. Comparisons between the ELISA test, the chloroplast agglutination test and the A6 cut leaf test .......................................................................................... 278

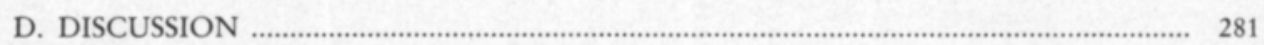

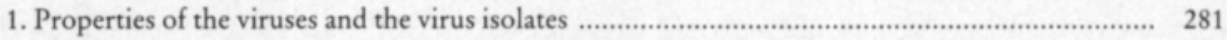

2. Identification methods …................................................................................................... 285

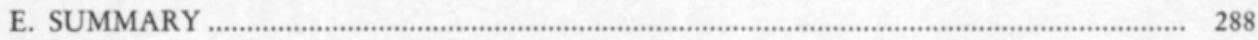

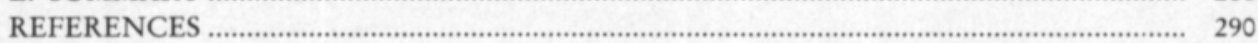

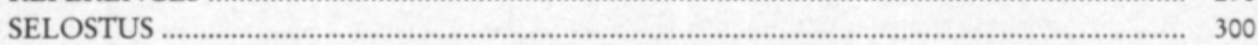


Abstract. The occurrence of potato viruses in Finland and alternative methods for their identification are reported in this study.

The following seven viruses were found to occur: potato viruses $\mathrm{X}, \mathrm{S}, \mathrm{M}, \mathrm{Y}, \mathrm{A}$, potato leaf roll virus (PLRV) and tobacco rattle virus (TRV). The isolates of potato viruses $\mathrm{X}$ and $\mathrm{Y}$ included two clearly distinct strains. The other viruses had only minor variants.

The most severe and important of the viruses was PVY, particularly its $\mathrm{Y}^{\circ}$ strain. Other important viruses were PVM and PVA and potentially PLRV. PVY was found to be the most easily transmitted in the field.

For serological identification of the viruses, indigenous antisera produced for selected isolates were mostly used. Significant serological variation was only found among the PVY isolates.

The lowest concentration of PVX D-protein detected with the agar gel double diffusion test was 10 $\mu \mathrm{g} / \mathrm{ml}$ and $1 \mu \mathrm{g} / \mathrm{ml}$ with the single diffusion test. With the ELISA test $0.1 \mathrm{ng}$ of virus $/ \mathrm{ml}$ could be detected. For PVX the lowest relative value detected in potato leaf sap was a dilution of between $10^{-6}$ and $10^{-7}$.

The chloroplast agglutination test was too unreliable for detecting PVY in potato samples. Also the agar gel double diffusion test was found to be too insensitive for the identification of potato viruses but the single diffusion test could be used in certain cases.

With the ELISA test potato viruses $\mathrm{X}, \mathrm{S}, \mathrm{M}$ and $\mathrm{Y}$ could be reliably detected in potato leaf sap and with almost the same accuracy in sap from sprouting tubers. The ELISA test was also found to give satisfactory results during routine testing for the identification of PVA and PLRV in potato leaves or non-dormant tubers.

\section{Introduction}

Virus diseases in potatoes in Finland have been known to be important since 1924. At this time cultivars were imported from England and Germany for experimental purposes to the Department of Plant Pathology of the Central Agricultural Experiment Station in Tikkurila and it was noticed that they displayed severe viral symptoms (JAMALAINEN 1946). In particular, many of the varieties were greatly affected by leaf roll. When experiments were continued with the same potatoes in subsequent growing seasons, more and more potato plants became affected with leaf roll and the tuber yields remained poor.

In the 1930's and the early 1940's virus diseases were commonly found in domestic potato breeding lines being grown at Tammisto near Helsinki (BRUMMER 1946). Even at this time certain diseases were known to be important. For example, severe secondary crinkle decreased the tuber yields of individual plants by $64 \%$ on average and secondary streak decreased yields similarily by up to $93 \%$. Later studies, carried out in the 1950 's by POHJAKALLIO et al. (1961), had similar findings. 
POHJAKALLIO et al. (1961) demonstrated that the same virus isolate could induce variable symptoms in different potato cultivars. POHJANHEIMO (1961) found that the cv. Tammisto Early remained latent after infection with PVY and was a dangerous carrier of the virus. The cultivar Jaakko was found by POHJANHEIMO (1962) to be an extremely sensitive indicator plant in determining PVY occurrence and transmission in the field. POHJANHEIMO (1962) also found that a higher percentage of infected potato plants occurred in the fields in the Southern parts of the country than in the other parts. Similar phenomena were found to occur in Sweden by ESBO (1946), who also demonstrated that high infection rates depend on a large aphid population being present in the crop.

The first attempts at serological identification of potato viruses in Finland were carried out by AURA (1957). All domestic seed potato lots tested were found to contain high percentages of tubers infected with PVX and PVS. Only two lots, originating from imported English and Dutch seed potatoes, of 26 tested, were virus-free. No significant differences in the rate of tuber infection from potatoes grown in different parts of the country were found.

Further studies on potato viruses were carried out in 1964-1966 by SEPPÄNEN (1972) who also studied the occurrence of PVY and PVA in Finland. The percent of PVX and PVS infected tubers in "merchant seed" was about $50 \%$ and also the proportion on PVS in quality seed had reached $70 \%$ on average. The percent occurrence of PVY was low in all tuber lots and PVA was not found at all.

The importance of virus-free seed potatoes as a factor in attaining high yields was often emphasized in the 1960's by HUOKUNA (1962), SEPPÄNEN (1963) and YLLÖ (1966), but it took several years before domestic virus-free seed potato production was initiated. The first indigenous cultivars, which were purified from viruses via heat treatment following tissue culture, were Pito and Tammisto Early and this was accomplished by TAPIO in 1972a. The growing seasons of 1973 and 1975, when there was a high rate of virus infection in potatoes, combined with this country's dependence on foreign seed potatoes to make the need for wide scale domestic seed potato production commonly understood. A year later the Seed Potato Center was founded at Liminka near Oulu, and it was assigned the responsibility of producing healthy seed potatoes for Finland.

For the production of healthy basic stocks of potatoes and the control of virus diseases during the course of large scale potato cultivation, reliable virus test methods are needed.

The purpose of this study was to improve the test methods for potato virus identification. In order to apply new technological achievements in virus testing, basic research about the viruses and their isolates had to be carried out. Thus this study emphasizes the main properties of the important viruses that occur in potatoes in Finland as this knowledge is crucial for the application of modern serological methods such as the ELISA test. 


\section{A. Materials and methods}

\section{Isolation of the viruses and their biological properties}

\subsection{The origin of the isolates}

All viruses examined were isolated in Viikki at the Department of Plant Pathology of the University of Helsinki between 1975-1982. Some of the isolates were of foreign origin, these being obtained via imported seed potatoes. During the spring of 1975 hundreds of tons of seed potatoes were imported into Finland (SEPPÄNEN \& HYTÖNEN 1977) and some of these were moderately infected with different viruses. Thus several isolates studied originated from this seed material. Also, many isolations made in the years after 1975 may be traced back to this imported material; particularly isolates from the cultivars Kaptah, Posmo, Prevalent, Prumex, Record and Saturna.

Other virus isolates originated from material sent from field inspections to the State Seed Testing Station or came from seed potatoes sent for statutory winter testing to this institute between 1975-1982. Most of this seed material was produced by seed potato growers in the vicinity of the Seed Potato Center at Tyrnävä.

Viruses were also isolated from potato cultivars and clones grown at the Hankkija Plant Breeding Institute at Tuusula and the Plant Breeding Institute, Agricultural Research Centre (A.R.C.) at Jokioinen. As well, several isolations were made from potatoes grown at experimental stations in Central Finland at Laukaa and Maaninka and from potatoes produced for the starch industry by Hämeen Peruna Ltd in Hämeenlinna and Prestoperuna Ltd in Kotka. Moreover, viruses were also isolated every year from field experiments at the University Farm in Viikki.

Random samples from virus-infected material were an important source of isolates. This material was collected from all over the country during the growing seasons and from tubers sent to the department during the wintertime.

If isolates of certain viruses from the same source proved to have the same properties only one isolate was selected and maintained for further studies. The number of these isolates that were studied further is as follows: Potato virus X (PVX) 21, potato virus S (PVS) 18, potato virus M (PVM) 15, potato virus $\mathrm{Y}$ (PVY) 48, potato virus A (PVA) 4, potato leaf roll virus (PLRV) 11 and tobacco rattle virus (TRV) 3.

\subsection{Isolation methods and the test plants used}

Most viruses were isolated from seedlings grown from virus infected tubers as part of a winter-testing program. Viruses were also isolated from infected leaf samples and tubers of different developmental stages that were collected in the field. Isolates of PVX, PVA and PVY were even taken from lesions initiated by the viruses in A6 cut leaf tests. 
For mechanical inoculations virus infected samples were ground with a mortar and pestle in $0.06 \mathrm{M}$ or $0.1 \mathrm{M}$ phosphate buffer at $\mathrm{pH} 7$ (one part sample/5-10 parts buffer). Carborundum dusted leaves of test plants were inoculated using one's forefinger and a cotton-tipped match or a muslin pad (for infectivity tests). Inoculated leaves were rinsed with tap water within 1-2 minutes.

Aphid transmission was used for the isolation of all viruses excluding PVX and TRV. This method was also used for further studies of the virus isolates. The aphid species normally used was Myzus persicae Sulz. For PLRV transmission experiments the species Aulacorthum solani Kltb. and Aphis nasturtii-frangulae Kltb. were used. For PVY transmission the use of Rhopalosiphum padi L. was studied. $R$. padi was raised on oats and the other aphid species were raised on potatoes. In aphid transmission experiments $3 \times$ 10 test plants were used but for isolation purposes the number of test plants used was 10 of each species needed. Three aphids were moved with a brush onto each test plant. The acquisition feeding time for nonpersistent viruses was $1-2 \mathrm{~min}$ and for the persistent (PLRV) virus $48-72 \mathrm{~h}$. The inoculation feeding times were $18-24 \mathrm{~h}$ and $48-72 \mathrm{~h}$ respectively. The aphids were killed by nicotine fumigation at the end of the inoculation feeding period. The test plants were then grown under normal greenhouse conditions for 3-8 weeks, depending on the virus and the host. The artificial illumination used in the greenhouses during the wintertime supplied $4000-5000$ lux for $16 \mathrm{~h}$ per day. The temperature in the greenhouses was $20 \mathrm{C}$ in the wintertime but varied between $20 \mathrm{C}$ and $40 \mathrm{C}$ in the summertime. All host range, symptomology and aphid transmission experiments and most of the virus isolations were carried out during the wintertime under good conditions. The test plants used in all experiments were young, healthy plants of equal size.

The following test plant species were used:

\section{Chenopodium amaranticolor Coste \& Reyn.}

Chenopodium quinoa Willd.

Datura metel L.

Datura stramonium L.

Gomphrena globosa L.

Lycopersicon chilense Dun.

Lycopersicon esculentum Mill. cvs. Kotitomaatti and Nevskij

Lycopersicon pimpinellifolium (Jusl.) Mill.

Nicandra physaloides L.

Nicotiana clevelandii Gray

Nicotiana debneyi Domin

Nicotiana glutinosa L.

Nicotiana tabacum L. cv. Samsun

Phaseolus vulgaris L. cvs. Red Kidney and Stella

Physalis floridana Rydb.

Pisum sativum L. cv. English sword

Solanum chacoense Bitt.

Solanum demissum A Lindl. (SdA) 
Solanum demissum Y Cock. (SdY)

Solanum demissum Y x Solanum tuberosum cv. Aquila (A6)

Solanum tuberosum $\mathrm{L}$. several cultivars

Solanum rostratum Dun.

Vicia faba L. cvs. Hankkija's Mikko and Pirhonen

For virus isolation a wide host range was used because some test plants were chosen in order to show the symptoms caused by possible unwanted contamination. For isolation potato virus $\mathrm{X}$ was inoculated mechanically onto the following plant species: G. globosa, N. glutinosa and N. tabacum cv. Samsun. From local lesions that developed on G. globosa leaves the virus was transmitted to $N$. glutinosa, in which it could be maintained for several months.

Potato virus $\mathrm{S}$ was mechanically inoculated onto the following species: $C$. quinoa, $N$. debneyi, $N$. glutinosa, $N$. tabacum cv. Samsun and S. rostratum. From local lesions on C. quinoa leaves the virus was transmitted again to $N$. debneyi and L. esculentum cv. Nevskij, in which it could be maintained for 1-4 months. The test plants used for aphid transmission were L. esculentum cv. Nevskij and $N$. debneyi.

Potato virus $\mathrm{M}$ was mechanically inoculated onto the following species: $L$. esculentum cv. Kotitomaatti, L. chilense, $N$. debneyi and $N$. tabacum cv. Samsun. The host used for aphid transmission was $L$. esculentum cv. Kotitomaatti in which the virus could be maintained for 2-4 months.

Potato virus $Y$ was mechanically inoculated onto the following species: $S$. demissum A, S. demissum Y, N. glutinosa, N. tabacum cv. Samsun, N. physaloides and $P$. floridana. The virus was re-inoculated from the top leaves of $S$. demissum $\mathrm{Y}$ that exhibited systemic vein necrosis to $N$. glutinosa, in which the virus could be maintained for 2-4 months. The hosts used for aphid transmission were $N$. glutinosa and S. demissum Y.

The test plant species used for potato virus A were $N$. glutinosa, $N$. tabacum cv. Samsun, N. physaloides, $P$. floridana and S. demissum A. No aphid transmission experiments were carried out. The virus was maintained in N. tabacum cv. Samsun for 1-3 months.

Potato leaf roll virus was transmitted via aphids to $D$. stramonium, $P$. floridana, S. demissum $\mathrm{Y}$ and also to potato cv. Sieglinde. Virus isolates were maintained in $P$. floridana for 3-6 months or in potato tubers for up to 24 months.

Tobacco rattle virus was isolated mechanically from potato tubers, roots and stocks. The test plant species used for isolation were C. amaranticolor, C. quinoa, $N$. clevelandii, $N$. debneyi, $N$. glutinosa and $N$. tabacum cv. Samsun. The virus was re-inoculated from local lesions in Chenopodium leaves to $N$. clevelandii, in which it could be maintained for 2-4 months. 


\subsection{Thermal inactivation point and dilution end point determination}

The thermal inactivation point (TIP) and the dilution end point (DEP) were determined for some of the isolates of each virus; the isolates being selected according to their symptomology in test plants. TIP was determined by heating $1 \mathrm{ml}$ of sap for $10 \mathrm{~min}$ in thin-walled tubes in a water bath followed by rapid cooling. Virus infected sap was diluted in cold distilled water for DEP determination. The virus sources and the indicator plants used were as follows:

PVX N. glutinosa $\rightarrow$ G. globosa

PVS $N$. debneyi $\rightarrow$ C. quinoa

PVM L. esculentum $\rightarrow$ L. esculentum

PVY N. glutinosa $\rightarrow$ S. demissum Y

PVA N. tabacum $\rightarrow$ S. demissum A

TRV N. clevelandii $\rightarrow$ C. amaranticolor

The lesions were counted and the other symptoms were observed within 6-21 days after inoculation. Potato virus $M$ was tested serologically in the sap of test plants 3 weeks after inoculation. TIP and DEP values were not determined for potato leaf roll virus.

\subsection{Virus preservation and their propagation for purification}

The virus isolates selected for further studies were maintained in test plants. Viruses were also preserved as dried material with calcium chloride or they were deep-frozen at $-20 \mathrm{C}$. By using all these methods most of the virus isolates kept their infectivity throughout the course of the research program. Potato leaf roll virus isolates and isolates of PVA and PVY were also preserved in potato tubers.

For virus purification, biologically pure virus isolates were propagated in the following hosts:

PVX N. glutinosa and N. tabacum cv. Samsun

PVS N. debneyi, L. esculentum cv. Nevskij and S. tuberosum cv. Pito

PVM L. esculentum cv. Kotitomaatti and L. chilense

PVY N. glutinosa and N. tabacum cv. Samsun

PVA N. tabacum cv. Samsun

PLRV P. floridana and S. tuberosum cv. Sieglinde

For virus propagation $30-100$ test plants were used simultaneously. Systemically infected leaves were collected every 10-20 days for Nicotiana spp. and $L$. esculentum plants or every 4-6 weeks for $N$. debneyi, $P$. floridana and S. tuberosum plants. The leaves were then deep-frozen at -20 $\mathrm{C}$ for later use or were used fresh (PVY, PVA, PLRV). The leaves infected with TRV were homogenised with a blender and the sap was deep-frozen to be further purified later (see KURPPA et al. 1981). 


\section{Electron microscopy}

For electron microscopy virus particles were negatively stained in preparations of plant sap or purified sap suspensions. The preparations were examined on carbon-coated grids and stained with either $1.5 \%$ phosphotungstate at $\mathrm{pH} 6.5$ or $2 \%$ ammonium molybdate at $\mathrm{pH} 6.5$. For PLRV studies thin sections of fixed plant material coated with epon were also examined. For these studies JEOL $100 \mathrm{~S}$ and JEOL 100B transmission electron microscopes were used. The electron micrographs were taken at fixed magnifications of $10000 \mathrm{x}, 20000 \mathrm{x}, 30000 \mathrm{x}$ or $50000 \mathrm{x}$ and then enlarged to the final magnification.

For electron microscope serology, antigen solutions of $10 \mu \mathrm{g} / \mathrm{ml}$ were used and the reaction end-point of an antiserum was taken as the greatest dilution of which antibody molecules could be seen attached to all virus particles (ROBERTS et al. 1979). This method was used to separate isolates of potato virus $\mathrm{Y}$ and isolates of tobacco rattle virus.

\section{Virus purification}

Virus isolates were purified from leaves that were systemically infected. For the purification of viruses $\mathrm{X}, \mathrm{S}$ and $\mathrm{M}$ the method described by SHEPARD (1972) was followed. Thus $0.5 \mathrm{M}$ borate buffer at $\mathrm{pH} 8.2$ was used for homogenise leaf material and polyethylen glycol was used as a solvent for virus concentration.

For the purification of PVY a method described by STACE-SMITH \& TREMAINE (1970), based on ether clarification and differential centrifugation, was used initially. As well, modifications of this based on chloroform (1:1) and chloroform/buthanol 1/1:1 clarification were tried for the first steps in the purification procedures. A third procedure used for PVY purification was a slightly modified version of the method described by LEISER \& RICHTER (1978). This method was also used for PVA purifications. For virus concentration high speed centrifugation was used.

For PLRV purification two different methods were used. One was based on enzyme-assisted plant material dispersal as described by TAKANAMI \& KUBO (1979) and the other was modified from the method described by CLARKE (1981). For better results with this modification the ELISA method was used to control all the steps in the purification procedure. TRV particles were purified as described by KURPPA et al. (1981).

Since the autumn of 1979 density gradient centrifugation has been used as the final step in separating impurities from virus particles. To prepare the gradient solutions of $20 \%$ (for filamentous viruses) or $25 \%$ (for other viruses) sucrose in buffer were first frozen in Beckman SW 27 tubes. The buffers used to make the gradients were the same ones which were used to resuspend the virus pellets during previous high speed centrifugation in all cases. The gradients were produced immediately before centrifugation by 
bringing the tubes to room temperature a few hours before use, thus allowing the solutions to thaw slowly.

The centrifugation times for each of the viruses were as follows: TRV 2.5 h, PVX, PVS, PVM, PVY and PVA about $3 \mathrm{~h}$ and PLRV $4 \mathrm{~h}$ at $24000 \mathrm{rpm}$. After centrifugation in a Beckman L-50 ultracentrifuge with a Beckman SW27 rotor the gradients were fractionated by upward displacement, using an ISCO Model 640 density gradient fractionator.

The highly purified virus particles in fractions were recovered from the sucrose solution by dilution and sedimentation for $70-100$ minutes at 45000 $\mathrm{rpm}$ in a Beckman 50-Ti rotor. The final sediments were resuspended in a low molar buffer with or without sodium azide depending on their purpose of use.

\section{Antiserum production and the properties of the antisera}

A blood sample (normal serum) of about $5 \mathrm{ml}$ was taken from each rabbit before the first injection. Antisera for potato viruses $\mathrm{X}, \mathrm{S}, \mathrm{M}$ and $\mathrm{Y}$ were produced by injecting $1 \mathrm{mg}$ of antigen in $1 \mathrm{ml}$ of buffer mixed 1:1 with Freunds adjuvant (complete adjuvant was used in the first injection and incomplete in the following injections) intramusculary. In each immunization program several injections were used, for details see tables 3,10,14 and 19. Antiserum collection was started 4-6 weeks after the first injection and after that the rabbits were bled over a period of several months at about two week intervals. Blood was taken from the marginal vein in the ear and 20-30 $\mathrm{ml}$ was taken at each bleeding.

For antiserum separation blood samples were left for 1-2 hours at room temperature to allow coagulation to occur and then were moved into a cold room overnight. The next day the clear serum solution was decanted out of the tubes and was centrifugated in a low speed centrifuge at $2000 \mathrm{~g} / 15 \mathrm{~min}$. The antiserum was stored in soft plastic tubes (NUNC) at $-20 \mathrm{C}$ or at $4 \mathrm{C}$ in $1: 1$ glycerol.

The antisera needed for the agar gel diffusion tests were produced by using degraded virus protein (D-protein) in the injections. To prepare the protein, purified virus suspensions of $1-2 \mathrm{mg} / \mathrm{ml}$ were mixed rapidly with equal volumes of $5 \%$ pyrrolidine. The mixtures were dialysed immediately in 3 changes of buffer solution. The immunization and blood collection programs are outlined in figs. 2, 11 and 18.

To determine the titers of the antisera the microprecipitin test of van SLOGTEREN (1955) was used in cases where the antisera were produced using whole virus particles as the immunogens. For titration $0.02 \mathrm{ml}$ of diluted antigen and antiserum solutions were mixed in a drop on a new plastic petri plate or on a Formwar coated petri plate made of glass. Evaporation from the drops was prevented by fixing a wet filter paper inside the cover of the petri plates. The antisera were diluted in 2 steps and the antigens in 4 steps starting from $0.5 \mathrm{mg} / \mathrm{ml}$. A saline solution was used as the control in all tests. The test 
results were read both after 4 hours and 20 hours of incubation.

The titers of the antisera produced with degraded virus protein were determined via a double diffusion test (van SLOGTEREN 1955). The $1 \%$ agar gels were $3 \mathrm{~mm}$ thick and holes were cut into them with a cork borer $4.5 \mathrm{~mm}$ in diameter. The distance between the central hole and the surrounding holes was $4 \mathrm{~mm}$. For titer determination antigen dilutions of $0.5 \mathrm{mg} / \mathrm{ml}, 0.125 \mathrm{mg} /$ $\mathrm{ml}$ and $0.031 \mathrm{mg} / \mathrm{ml}$ were used. The gels were incubated at $4 \mathrm{C}$ and were examined 1, 2 and 4 days later.

To determine heterologous titers and the relationships between the viruses and virus isolates, the microprecipitin and gel diffusion tests were used with the antigen concentrations mentioned above. For comparison with foreign antisera, serum preparates of the following origin were tested: Danish antisera, Statens Førsøgsvirksomhed i Plantekultur, Lyngby; Estonian antisera, Jogeva Plant Breeding Station; Polish antisera, Institut Ziemniaka, Bonin; Hungarian antisera, Agrártudomànyi Egyetem Burgonyanemesitö Osoport, Keszthely.

To determine the serological relationships between Finnish virus isolates the EM-serological AVM (antibody-virus mixture) method (ROBERTS et al. 1979) and the ELISA test were used.

\section{Identification methods}

\subsection{Chloroplast agglutination, microprecipitin and cut leaf tests}

Antisera produced for virus isolates in this study were compared with the antisera earlier produced at the Department of Plant Pathology and with the antisera of foreign origin in microprecipitin tests using purified virus and clarified virus-containing sap as antigens. Similar comparisons were also made with chloroplast agglutination tests using potato leaf sap (see van SLOGTEREN 1955, BALL 1961). The results obtained from the serological identification of PVY were compared with biological A6- and $\mathrm{TE}_{1}$-cut leaf tests (KÖHLER 1953, de BOKX 1974). An attempt was made to try to improve the reaction specificity and the reliability of the chloroplast agglutination test by adding $0.4 \%$ sodium sulphite (STASZEWICZ 1977) or $1 \%$ bentonite to the diluted antisera. Otherwise the tests were carried out as originally described. The results of the agglutination tests were read under the microscope after 2 hours of incubation at room temperature and the results of the cut leaf tests were read 7 days after incubation at 20-22 C with 2000 lux of continuous illumination.

\subsection{Gel diffusion tests}

In order to identify potato viruses $\mathrm{X}, \mathrm{S}$ and $\mathrm{M}$ by means of gel diffusion tests, leaf or tuber sap was mixed with an equal volume of $5 \%$ pyrrolidine. 
Otherwise the tests were made as described above. In routine tests the antiserum in a $1 / 8$ dilution was placed in the central hole. Test plates were read after 2 days of incubation at $4 \mathrm{C}$.

For single diffusion tests (MANCINI et al. 1964, SHEPARD \& SECOR 1969) the gel plates were prepared by mixing undiluted antiserum with a $1 \%$ agar gel solution at $50 \mathrm{C}$. Several antiserum dilutions were tested but in routine tests a final antiserum concentration of $1 / 50$ in agar was used. Holes were cut in $2 \mathrm{~mm}$ thick agar with a cork borer $4.5 \mathrm{~mm}$ in diameter and the distance between the holes varied from 5 to $10 \mathrm{~mm}$. The test samples were prepared as described for the double diffusion test. The results were read after 1, 2, 4 and 24 hours of incubation at $4 \mathrm{C}$.

\subsection{ELISA test}

The preparative steps, antibody purifications and conjugate preparations for the ELISA test were carried out as described by CLARK \& ADAMS (1977). However, excluding the initial experiments, total immunoglobulin instead of the $\gamma$-globulin fraction was used for coating the plates and for conjugate preparation, because in the course of further antibody purification heavy losses of antibodies were found to be caused by the DEAE-cellulose treatment.

Microtitration plates made by several manufactures were tested but Lindbro microtitration plates $76301-05$ or E.I.A. plates 76381-04 (Flow Laboratories, Hamden U.S.A.) and Microstrip ${ }^{R}$-plates (Eflab Ltd, Helsinki, Finland) were usually used. In all steps of the ELISA test (see CLARK \& ADAMS 1977) $200 \mu \mathrm{l}$ of reagents or samples were placed into the wells of the plates. To place the test samples into the wells a 1-channel pipette (Finnpipette Ltd, Helsinki) was used. Test reagents were placed with a multichannel dispenser (Eflab Ltd, Helsinki).

Reaction absorbances were measured with a Titertek Multiscan photometer (Eflab Ltd, Helsinki) at a wavelength of $405 \mathrm{~nm}$. In routine tests absorbance measurements were carried out after 30-60 mins of substrate incubation at $22 \mathrm{C}$. In order to study the specificity and sensitivity of this method different incubation times were tested. Viruses were identified from dormant tubers, sprouted tubers and potato leaf sap. To determine the quantitative sensitivity of the test purified virus antigen was used. Relative sensitivity was determined by using serial dilutions of different virus infected plant material. The ELISA method was also used in the serological classification of virus isolates and to improve the purification methods for virus $\mathrm{Y}$ and potato leaf roll virus.

The potato samples studied were selected so that comparisons could be made between the different virus identification methods. 


\section{Field experiments and statistical analysis of the results}

Several field experiments were carried out to study virus transmission, viral symptomology in different potato cultivars and the yield losses caused by viruses. Suitable material for virus identification studies was simultaneously obtained from these experiments.

Only some of the results obtained from the field experiments are reported here. Those reported deal particularly with natural virus transmission and other important differences between the potato virus isolates. The main purpose of this work was to study virus properties in relation to their serological identification and to improve serological methods for reliable virus identification in routine work.

Because of the aim of this study statistical analyses were seldom needed to verify the reliability of the results obtained.

\section{B. The viruses and the virus strains found in Finland and their properties}

\section{Potato virus X (PVX)}

Potato virus $\mathrm{X}, \mathrm{R} / 1: 2.1 / 6: \mathrm{E} / \mathrm{E}: \mathrm{S} /(\mathrm{Fu})$, is distributed worldwide in potato growing areas. It consists of elongated particles with a normal length of 515 $\mathrm{nm}$. The virus was first described by Smith in 1931 (BERCKS 1970). The following synonyms have been used for the virus: "Healthy potato virus" (JOHNSON 1936), Potato latent virus, Potato mosaic virus and Solanum virus 1 (BERCKS 1970).

The host range is mainly limited to the Solanaceae although some plants in other families are susceptible and may maintain the virus in the field (ALLEN \& DAVIS 1981).

Potato virus $\mathrm{X}$ causes mild mosaic of potato, mosaic and stunting of tomato, and mottle or necrotic ring spotting of tobacco. The virus is mainly transmitted by contact (BERCKS 1970) but some insects are probably able to transmit it mechanically on their mouthparts (WALTERS 1952). Transmission has also been reported by the fungus Synchytrium endobioticum (NIENHAUS \& STILLE 1965).

According to several field experiments the virus causes yield losses of 0-10\% (REESTMAN 1970, van der ZAAG 1977, MANZER et al. 1979) but also heavy yield losses of up to $74 \%$ have been reported (KLINKOWSKI 1951). In good potato growing conditions the tuber yield losses have been $0.10-0.30$ $\%$ for every one percent of virus infected plants found in the field (BONDE \& MERRIAM 1951, BONDE 1953, BORCHARDT et al. 1964). 
Potato virus X may have been detected serologically as early as the 1930's (CHESTER 1937).

\subsection{Symptoms in potatoes and test plants and virus strain classification}

All isolates caused mild symptoms in potatoes and some of them were completely latent. When virus $\mathrm{X}$ was isolated from plants with mixed infections visible symptoms were always found. Potato virus $\mathrm{X}$ was common in seed potato in Finland still in the 1970's (Table 6, page 208).

The typical symptoms caused by the isolates belonging to the common strain are mild mosaic and vein clearing. A strain type with different symptoms was found occurring naturally in the cvs. Ostara, Prumex and Saturna. Isolates of this strain causes leaf-narrowing, vein-clearing and faint chlorotic ring spots in potatoes (Fig. 3, page 206). These isolates were transmitted quickly in the field although only the mechanical means of transmission could be demonstrated (Fig. 1).

The viruses isolated from potatoes were classified according to the symptoms they caused in test plants. No symptom variation was found in the following test plants:

Chenopodium amaranticolor: Small chlorotic local lesions in 5-8 days; later the inoculated leaves became reddish and dropped.

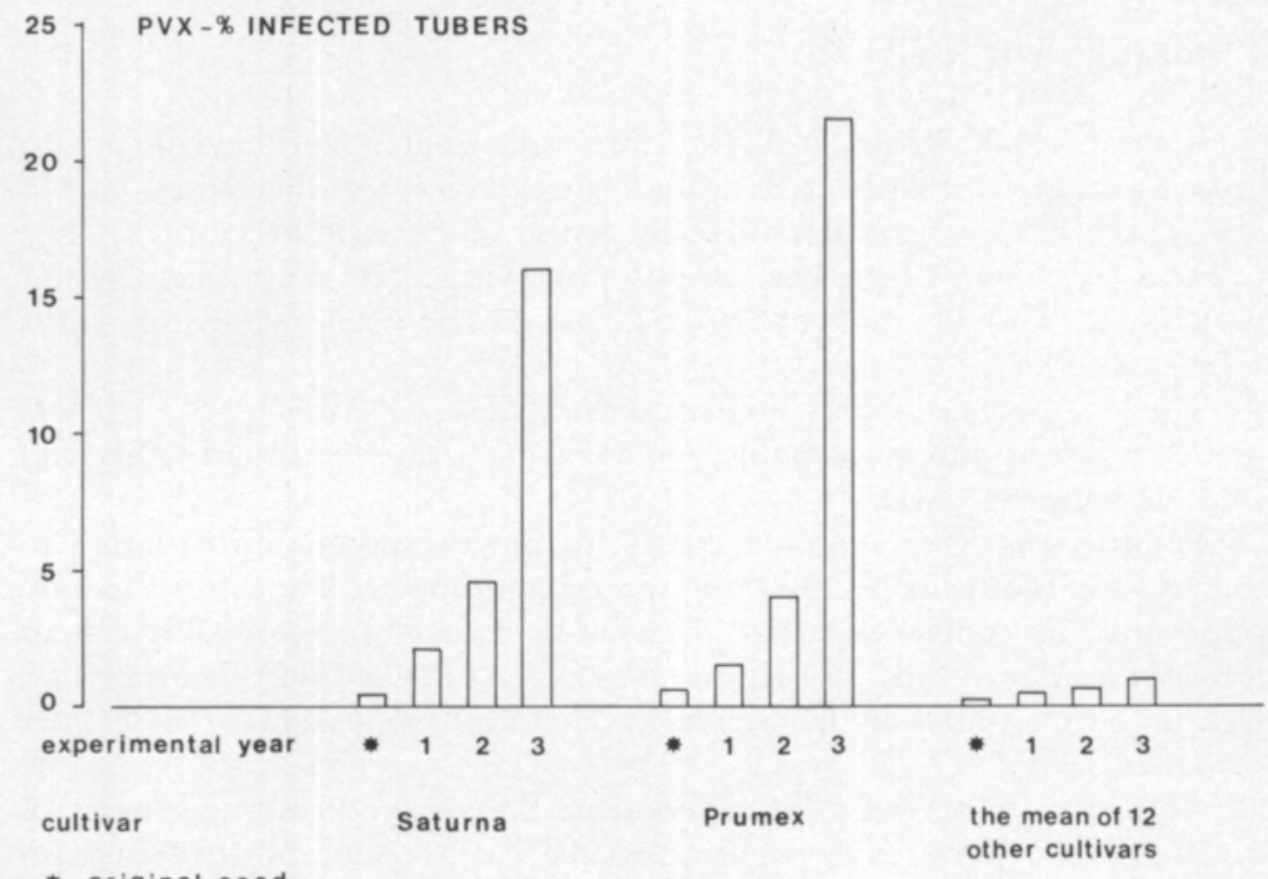

* original seed

$1,2,31$ st, 2 nd, 3 rd years seed

Fig. 1. Natural transmission of PVX in field experiments at Viikki during three successive growing seasons using seed material from the previous crop. 
C. quinoa: Small chlorotic local lesions in 4-7 days. The inoculated leaves became chlorotic and dropped immaturely in 14-22 days.

Gomphrena globosa: Necrotic local lesions in 2-4 days. The lesions grew larger and developed red margins in 6-8 days (Fig. 4).

The PVX isolates were classified into two strains according to the symptomology of the following test plants (see SALAMAN 1938, LADEBURG et al. 1950, VARMA et al. 1970):

I Common strain ("mild mosaic" strain):

Datura stramonium: Faint chlorotic local rings or no local symptoms; mild systemic mosaic and chlorosis in 6-9 days.

Lycopersicon esculentum: Mild systemic mosaic and necrosis in 6-8 days. A6: No local symptoms; systemic chlorosis and necrosis in 10-14 days.

Solanum chacoense: No local symptoms; systemic mottle and necrosis in 10-14 days.

Nicotiana glutinosa: No local symptoms; systemic mosaic, mottle and stunting in 7-10 days.

N. tabacum cv. Samsum: No local symptoms; systemic vein clearing and faint mottle in 7-10 days (Fig. 5).

The origin of the isolates of the "mild mosaic" strain was as follows:

XSF1, Tammisto Early, Tikkurila

1975

XSF2, Pito, Seed Testing Institute

XSF5, Record, Hankkija Plant Breeding Institute

1976

XSF8, Veto, Plant Breeding Institute, A.R.C.

1976

XSF9, Kaptah, Danish imported seed

1976

XSF11, Hja's Tuomas, Hankkija Plant Breeding Institute 1977

XSF18, Bintje, Renko

1982

XSF19, Record, Tyrnävä

1982

XSF20, Bintje, Seinäjoki

1982

XSF21, Record, Hämeenlinna

1982

\section{Ringspot strain:}

D. stramonium: Chlorotic local rings in 4-6 days; systemic mottle, mosaic and necrosis in 6-8 days.

L. esculentum: No local symptoms; systemic mosaic, yellowing and necrosis A6: Small necrotic local spots and lesions in 3-5 days; systemic chlorosis and deformation in $8-14$ days (Fig. 9).

S. chacoense: Small necrotic local spots in 3-6 days; systemic chlorosis and necrosis in $8-14$ days.

N. glutinosa: Chlorotic or necrotic ringspots in 4-6 days; severe systemic mosaic and deformation in 7-10 days; occasionally systemic leaf necrosis (Fig. 6).

N. tabacum cv. Samsun: Chlorotic and necrotic local rings in 4-6 days; systemic chlorotic and necrotic rings and vein clearing in 6-8 days (Figs. 7 and 8 ). 
The isolates belonging to the ringspot strain of PVX originated as follows:

XSF3, Saturna, Dutch imported seed

1975

XSF4, Ostara, -"-

XSF6, Saturna, Prestoperuna Ltd

1976

XSF7, Prumex, -"-

1976

XSF10, Saturna, -"-

1977

XSF12, Prumex, -"-

1977

XSF13, Saturna, Loppi

1979

XSF14, Saturna, Tyrnävä

1980

XSF15, Ostara, Porvoo

1982

XSF16, Ostara, Porvoo

1982

XSF17, Saturna, Pyhtää

1982

Minor variants with similar host ranges and symptomology within these strains were grouped together and from these 4 type isolates were selected for further studies.

\subsection{Sap properties and virus purification}

\subsubsection{Thermal inactivation point and dilution end point}

All isolates studied lost their infectivity at at least $72 \mathrm{C}$ when viruscontaining $N$. glutinosa sap was heated for $10 \mathrm{~min}$. The isolates XSF1 and XSF2 of the mild strain were inactivated at lower temperatures than the ringspot strain isolates XSF6 and XSF13 (Table 1). Gradual inactivation was found to start at temperatures lower than $60 \mathrm{C}$.

The mild strain isolates of PVX were inactivated when sap of systemically

Table 1. The mean number of local lesions on Gomphrena globosa leaves inoculated with Nicotiana glutinosa sap containing PVX isolates heated for $10 \mathrm{~min}$ at different temperatures.

\begin{tabular}{ccccc}
\hline & \multicolumn{4}{c}{$\begin{array}{c}\text { Lesions/leaf (4 replicates) } \\
\text { Isolate }\end{array}$} \\
Temperature C & XSF1 & XSF2 & XSF6 & XSF13 \\
\hline Unheated & $>30$ & $>30$ & $>30$ & $>30$ \\
54 & $>30$ & $>30$ & $>30$ & $>30$ \\
57 & 21.3 & 26.5 & 27.3 & $>30$ \\
60 & 11.3 & 16.5 & 16.0 & 21.8 \\
63 & 5.0 & 8.3 & 12.3 & 13.5 \\
66 & 0.0 & 1.8 & 3.0 & 6.0 \\
69 & 0.0 & 0.0 & 1.0 & 2.5 \\
72 & 0.0 & 0.0 & 0.0 & 0.0 \\
75 & 0.0 & 0.0 & 0.0 & 0.0 \\
78 & 0.0 & 0.0 & 0.0 & 0.0 \\
\hline
\end{tabular}


Table 2. The mean number of local lesions on Gomphrena globosa leaves inoculated with diluted Nicotiana glutinosa sap containing PVX isolates.

\begin{tabular}{lcccc}
\hline & \multicolumn{4}{c}{ Lesions/leaf (4 replicates) } \\
Dilution & XSF1 & XSF2 & XSF6 & XSF13 \\
\hline $10^{\circ}$ & $>30$ & $>30$ & $>30$ & $>30$ \\
$10^{-1}$ & 23.5 & 27.0 & 23.5 & $>30$ \\
$10^{-2}$ & 12.0 & 15.3 & 13.0 & 24.5 \\
$10^{-3}$ & 7.3 & 7.5 & 9.8 & 16.3 \\
$10^{-4}$ & 3.0 & 4.0 & 4.5 & 8.0 \\
$10^{-5}$ & 1.0 & 1.5 & 3.0 & 6.8 \\
$10^{-6}$ & 0.0 & 0.0 & 0.5 & 2.0 \\
$10^{-7}$ & 0.0 & 0.0 & 0.0 & 0.0 \\
$10^{-8}$ & 0.0 & 0.0 & 0.0 & 0.0 \\
\hline
\end{tabular}

infected $N$. glutinosa was diluted to $10^{-6}$. The isolates of the ringspot strain lost their infectivity when diluted to $10^{-7}$ (Table 2).

Longevity in vitro values were not carefully determined but all isolates were infective after 2 months of incubation at room temperature.

\subsubsection{Virus purification}

The following maximum yields of purified virus preparates were obtained with the method described by SHEPARD (1972): XSF1 $=360 \mathrm{mg}$, XSF2 $=$ $480 \mathrm{mg}$, XSF6 $=540 \mathrm{mg}$ and XSF13 $=650 \mathrm{mg} / 1 \mathrm{~kg}$ systemically infected $N$. glutinosa leaves. The purity of the preparates before density gradient centrifugation was fairly good. In $5-35 \mathrm{w} / \mathrm{v}$ and $10-40 \mathrm{w} / \mathrm{v}$ linear sucrose gradients the virus moved as a single narrow band. All purified virus preparates could be stored in $0.05 \mathrm{M}$ borate buffer of $\mathrm{pH} 8.2$ containing 0.02 $\%$ sodium azide at $4 \mathrm{C}$ for at least 2 years without loss of infectivity. The A260/A280 ratio was 1.20 for all isolates.

\subsubsection{Electron microscopy}

Numerous filamentous virus particles were found in all negatively stained preparates made from infected potato or test plant leaf sap. The typical particle length in PTA $(1.5 \%, \mathrm{pH} 6.5)$ stained preparates was $510-520 \mathrm{~nm}$ and the typical diameter was $12 \mathrm{~nm}$. The virus particles, as seen with the electron microscope, were slightly bent and often occurred in groups of several particles (Fig. 59, page 251). The virus could usually be reliably separated from other filamentous potato viruses because of its very high particle consentration, typical particle length and habit of aggregation.

In purified preparations the virus particles kept their typical properties. However, broken particles of different length were found more frequently than in sap preparates. 


\subsection{Serological properties}

\subsubsection{Homologous titers of the antisera}

All of the 4 PVX isolates studied proved to be good immunogens when injected intramusculary into rabbits. Titers high enough for serological tests $(1 / 2048-1 / 8192$ in microprecipitin tests) were reached $3-5$ weeks after the first injection (Table 3 ). Repeated injections did not significantly raise the titers of the antisera, and the titers remained high for several weeks after the final injection. The isolates of the ringspot strain had higher titers than those of the mild mosaic strain and they also reached a higher level more quickly. The non-specific titers of all antisera were $1: 4$ or more lower when they were determined with the microprecipitin or the chloroplast agglutination test.

Table 3. Injection and sampling schedules, and homologous titers of the antisera as determined with the microprecipitin test. $\rightarrow=$ injection.

\begin{tabular}{|c|c|c|c|c|}
\hline \multirow{2}{*}{$\begin{array}{l}\text { Time in } \\
\text { weeks }\end{array}$} & \multicolumn{4}{|c|}{ Virus isolate and titer of the antiserum } \\
\hline & XSF1 & XSF2 & XSF6 & XSF13 \\
\hline 0 & $\rightarrow$ & $\rightarrow$ & $\rightarrow$ & $\rightarrow$ \\
\hline 1 & $\rightarrow$ & $\rightarrow$ & $\rightarrow$ & $\rightarrow$ \\
\hline 2 & $\rightarrow$ & $\rightarrow$ & $\rightarrow$ & $\rightarrow$ \\
\hline 3 & $\rightarrow 1 / 512$ & $\rightarrow 1 / 512$ & $\rightarrow 1 / 2048$ & $\rightarrow 1 / 4096$ \\
\hline 4 & & & & \\
\hline 5 & $1 / 2048$ & $1 / 2048$ & $1 / 4096$ & $1 / 4096$ \\
\hline 6 & & & & $\rightarrow$ \\
\hline 7 & $1 / 2048$ & $\rightarrow 1 / 2048$ & $1 / 4096$ & \\
\hline 8 & & & & $1 / 8192$ \\
\hline 9 & $\rightarrow 1 / 1024$ & $1 / 4096$ & $\rightarrow$ & \\
\hline 10 & & & & $1 / 4096$ \\
\hline 11 & $1 / 2048$ & $1 / 8192$ & $1 / 8192$ & $\rightarrow$ \\
\hline 12 & & & & \\
\hline 13 & $1 / 2048$ & $1 / 4096$ & $1 / 8192$ & $1 / 8192$ \\
\hline 14 & & & & \\
\hline 15 & $1 / 1024$ & $1 / 2048$ & $1 / 4096$ & $1 / 8192$ \\
\hline 16 & $\rightarrow$ & $\rightarrow$ & & \\
\hline 17 & & & $1 / 4096$ & $1 / 4096$ \\
\hline 18 & $1 / 4096$ & $1 / 4096$ & & \\
\hline 19 & & & & \\
\hline 20 & $1 / 2048$ & $1 / 4096$ & & \\
\hline 21 & & & & \\
\hline 22 & $1 / 2048$ & $1 / 2048$ & & \\
\hline 23 & & & & \\
\hline 24 & & $1 / 1024$ & & \\
\hline 25 & & $\rightarrow$ & & \\
\hline 26 & & & & \\
\hline 27 & & $1 / 4096$ & & \\
\hline 28 & & & & \\
\hline 29 & & $1 / 4096$ & & \\
\hline 30 & & & & \\
\hline 31 & & & & \\
\hline 32 & & $1 / 2048$ & & \\
\hline
\end{tabular}




\subsubsection{Heterologous titers of the antisera}

Slight serological strain specificity was found when antisera taken in the early stage of sampling (5 weeks from the 1st injection) were tested with heterologous antigens. The heterologous reactions in the microprecipitin test were always rather strong and the lowest heterologous titer determined was $1 / 1024$ (Table 4). The antisera for isolates of the same strain were almost identical.

Table 4. Homologous and heterologous titers of the antisera of PVX isolates as determined with the microprecipitin test; antigen concentrations: $250-4 \mu \mathrm{g} / \mathrm{ml}$.

\begin{tabular}{lllll}
\hline Antigen & \multicolumn{4}{c}{ The antiserum and its titer } \\
& XSF1 & XSF2 & XSF6 & XSF13 \\
\hline XSF1 & $1 / 2048$ & $1 / 2048$ & $1 / 1024$ & $1 / 1024$ \\
XSF2 & $1 / 2048$ & $1 / 2048$ & $1 / 1024$ & $1 / 2048$ \\
XSF6 & $1 / 1024$ & $1 / 1024$ & $1 / 4096$ & $1 / 4096$ \\
XSF13 & $1 / 1024$ & $1 / 1024$ & $1 / 2048$ & $1 / 4096$ \\
\hline
\end{tabular}

The antisera of foreign origin reacted moderately with the antigens studied. The Polish antiserum had a significantly weaker reaction than the other antisera (Table 5). All the foreign antisera could be used, however, for potato virus $\mathrm{X}$ identification in our country.

Table 5. The highest titers determined for 2 indigenous and 4 foreign antisera against PVX antigens XSF2 and XSF6 with the microprecipitin test; antigen concentration: $250-4 \mu \mathrm{g} / \mathrm{ml}$.

\begin{tabular}{lcccccc}
\hline Antigen & & \multicolumn{5}{c}{ The antiserum and its titer } \\
& XSF2 & XSF6 & X Estonian & X Polish & X Danish & X Hungarian \\
\hline XSF2 & $1 / 8192$ & $1 / 2048$ & $1 / 2048$ & $1 / 512$ & $1 / 4096$ & $1 / 2048$ \\
XSF6 & $1 / 2048$ & $1 / 8192$ & $1 / 1024$ & $1 / 512$ & $1 / 1024$ & $1 / 1024$ \\
\hline
\end{tabular}

\subsubsection{Immunogenesis of the degraded antigen}

The purified PVX preparate (XSF1), degraded with pyrrolidine, caused an increase in antibody formation when injected into rabbit. The titer rose slowly and then only remained at the same level for a few weeks. The highest titer determined with the double diffusion test was $1 / 128$ and it was reached 4 weeks from the beginning of the injection schedule. The same titer was reached again later when the injections were repeated (Fig. 2). The heterologous titers of the antiserum against the other PVX isolates were as follows: $\mathrm{XSF} 2=1 / 128, \mathrm{XSF} 6=1 / 64$ and XSF13 $=1 / 64$.

The most suitable concentration of degraded virus protein for the double diffusion test was $250-500 \mu \mathrm{g} / \mathrm{ml}$. A higher concentration of antigen was responsible for antigen/antibody disproportion, which could be detected as a double precipitin line or a broad diffusive precipitin line. A significantly 


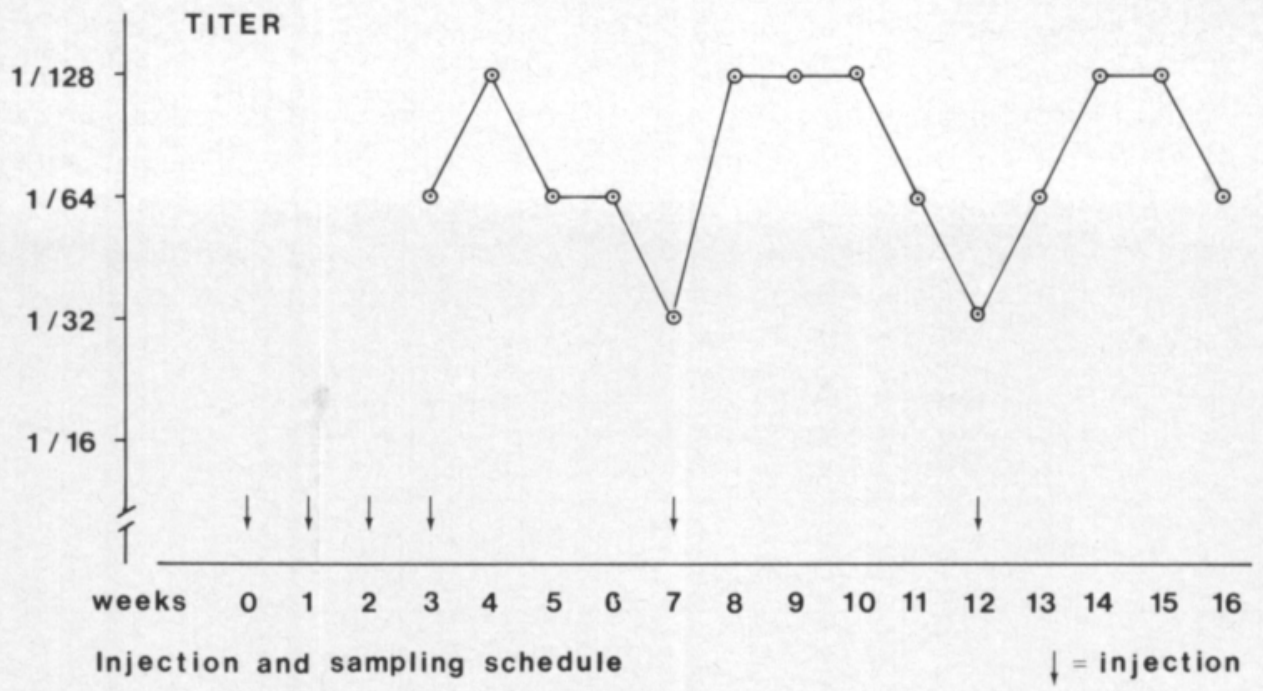

Fig. 2. PVX-D-antiserum production procedure and the titer of the antiserum as determined by the double diffusion test during the course of programme.

lower antigen concentration was responsible for a sharp but weakly visible precipitin line.

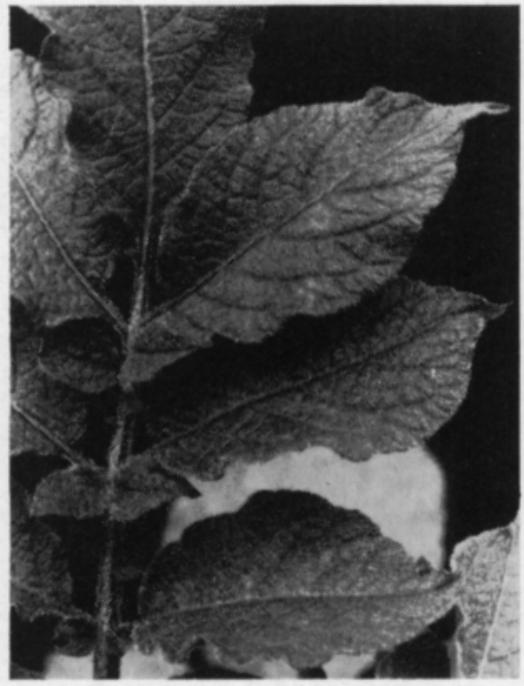

Fig. 3

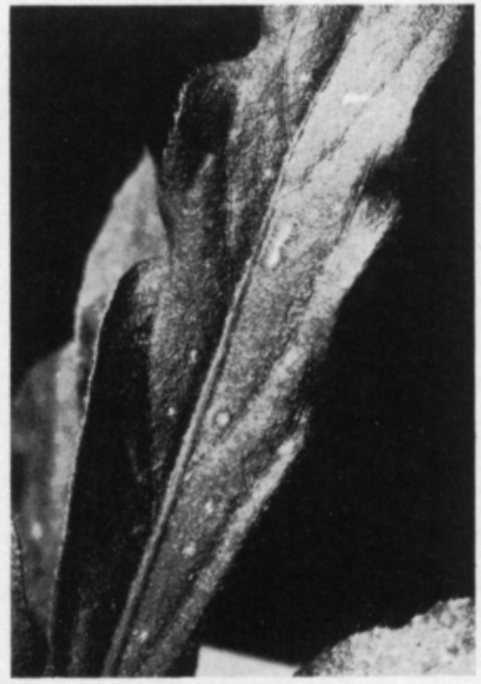

Fig. 4

Fig. 3. Chlorotic ringspots induced by the ringspot strain of PVX in potato cv. Saturna leaves.

Fig. 4. Necrotic local lesions in Gomphrena globosa leaves as induced by each PVX isolate. 


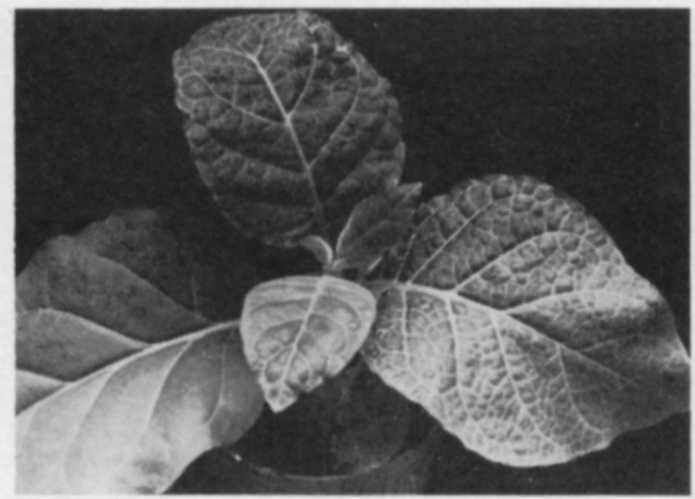

Fig. 5

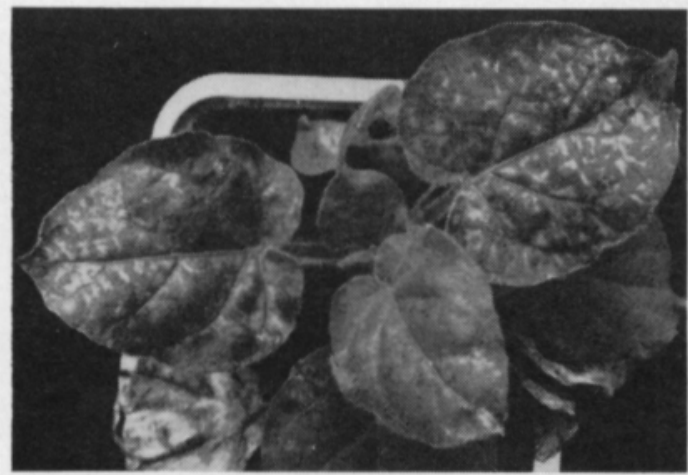

Fig. 6

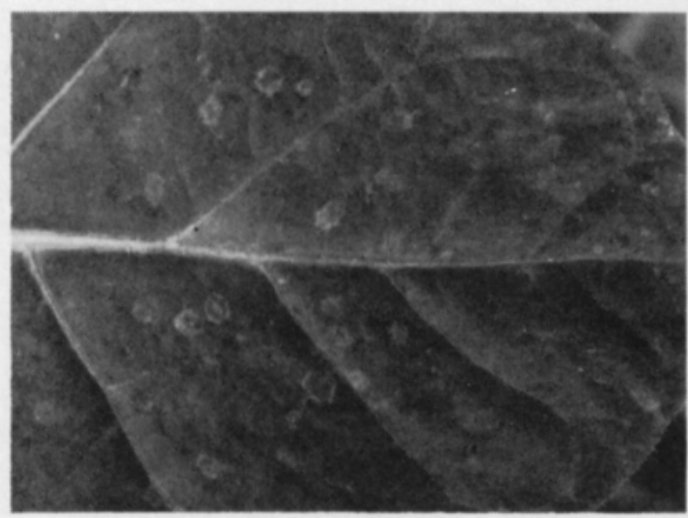

Fig. 7

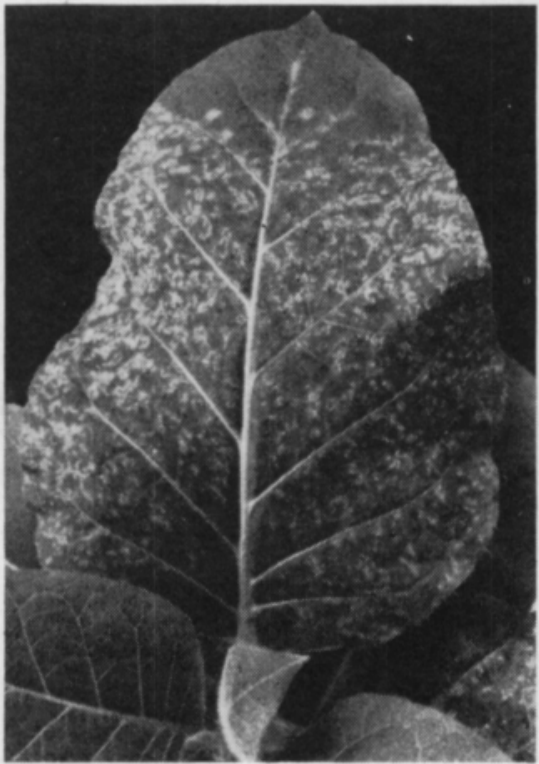

Fig. 8

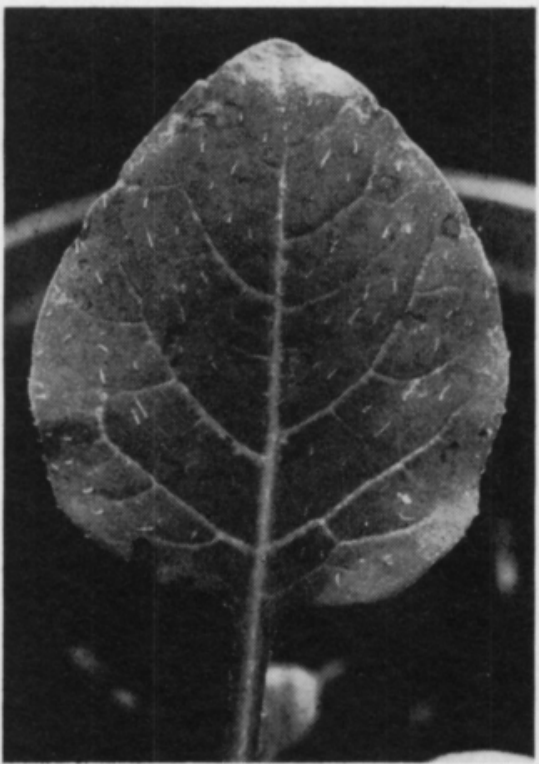

Fig. 9

Fig. 5 Vein clearing and vein mosaic in Nicotiana tabacum cv. Samsun induced by the most mild strain isolates of PVX.

Fig. 6. Severe yellow mosaic symptoms in Nicotiana glutinosa infected with the ringspot strain of PVX, isolate XSF14.

Figs. 7 and 8. Systemic chlorotic and necrotic rings and concentric rings in Nicotiana tabacum cv. Samsun leaves induced by the ringspot strain of PVX, isolate XSF 10 (Fig. 7) and isolate XSF14 (Fig. 8).

Fig. 9. Local necrotic spots and lesions of different sizes in Solanum demissum leaves induced by the ringspot strain isolates of PVX. 


\section{Potato virus S (PVS)}

Potato virus $\mathrm{S}, * / *: * / * \mathrm{E} / \mathrm{E}: \mathrm{S} / \mathrm{Ap}$, is a virus with straight to slightly curved filamentous particles c. $650 \times 12 \mathrm{~nm}$ (WETTER \& BRANDES 1956). PVS is a member of the Carla-virus group (HARRISON et al. 1971). The virus was first described by de BRUYN OUBOTER (1952) and ROZENDAAL (1952). The virus is sap and aphid transmitted (BODE \& WEIDEMANN 1971). It is found all over the world in cultivated potatoes and is nowadays probably the most common of the potato viruses (KOWALSKA 1978).

Potato virus $\mathrm{S}$ is widely reported as an inducer of mild diseases (van der ZAAG 1977, MANZER et al. 1978, 1979) but it can also cause significant yield losses in potato tubers of up to $20 \%$ (WETTER 1971). The virus causes few or no symptoms alone but in mixed infections with potato virus $\mathrm{M}$ the symptoms are easily visible (HUNNIUS 1976).

The host range of PVS is narrow and its importance is restricted to potatoes. However other susceptible species exist and they belong mainly to the genera Chenopodium, Lycopersicon, Nicotiana and Solanum (BAGNALL et al. 1956, HORVATH 1964, VULIC \& HUNNIUS 1967, ROSS 1968, de BOKX $1970 b)$.

Table 6. The occurrence of the most common potato viruses in commercial seed potato lots tested at the Department of Plant Pathology in 1975 and 1976.

\begin{tabular}{|c|c|c|c|c|c|}
\hline \multirow{2}{*}{\multicolumn{2}{|c|}{ Cultivar }} & \multicolumn{4}{|c|}{$\%$ of tested tubers infected with a virus } \\
\hline & & PVX & PVS & PVM & PVY \\
\hline \multicolumn{2}{|c|}{ Ostara } & 0 & 30 & 0 & 2 \\
\hline \multicolumn{2}{|c|}{ Prevalent } & 0 & 40 & 10 & 4 \\
\hline \multicolumn{2}{|c|}{ Saturna } & 15 & 9 & 2 & 0 \\
\hline \multicolumn{2}{|c|}{ Hja's Tuomas } & 12 & 92 & 19 & 0 \\
\hline \multicolumn{2}{|c|}{ Veto } & 3 & 60 & 0 & 0 \\
\hline \multirow[t]{10}{*}{ Pito } & 1 & 0 & 27 & 17 & 6 \\
\hline & 2 & 2 & 15 & 0 & 4 \\
\hline & 3 & 0 & 26 & 0 & 4 \\
\hline & 4 & 4 & 62 & 43 & 23 \\
\hline & 5 & 3 & 51 & 16 & 3 \\
\hline & 6 & 8 & 44 & 30 & 14 \\
\hline & 7 & 11 & 65 & 12 & 41 \\
\hline & 8 & 26 & 59 & 60 & 8 \\
\hline & 9 & 3 & 39 & 9 & 37 \\
\hline & 10 & 8 & 33 & 14 & 11 \\
\hline \multicolumn{2}{|c|}{ Record 1} & 1 & 42 & 67 & 31 \\
\hline \multicolumn{2}{|c|}{2} & 0 & 0 & 2 & 0 \\
\hline & 3 & 0 & 0 & 0 & 0 \\
\hline & 4 & 1 & 0 & 0 & 0 \\
\hline & 5 & 0 & 4 & 12 & 2 \\
\hline & 6 & 0 & 0 & 0 & 0 \\
\hline & 7 & 0 & 2 & 3 & 0 \\
\hline Jaakko & 1 & 14 & 41 & 9 & 17 \\
\hline & 2 & 27 & 59 & 13 & 12 \\
\hline
\end{tabular}




\subsection{Occurrence, symptomology and transmission}

Potato virus $\mathrm{S}$ was very common in potatoes grown in Finland until the end of the 1970's, when the use of healthy seed potato became established (AURA 1957, SEPPÄNEN 1972, 1974, YLLÖ 1975). Some of the most widely grown cultivars were totally infected with virus $\mathrm{S}$ (Table 6).

The virus occurred in most cultivars showing only very mild symptoms and it was impossible to decide with the naked eye whether a potato plant was infected or not. In some cultivars, e.g. Pito and Sanna, symptoms of interveinal mosaic and chlorotic spots between the veins, were easily visible (Fig. 12, page 216). When symptoms existed they were clearest at the time of blooming or immediately after it. The symptoms were more typical of the cultivars than of the virus isolates.

Natural transmission in the field was very rapid if the cultivar was susceptible. The cultivars susceptible to virus $\mathrm{S}$ were simultaneously susceptible to virus $\mathrm{M}$ (Fig. 10).

Most PVS isolates were readily aphid transmitted. However, significant variation in aphid transmission between the virus isolates were found (Table 7).

Similar symptoms appeared $24-30$ days after inoculation in test plants that were mechanically inoculated.

Fig. 10. Natural transmission of PVS and PVM in field experiments at Viikki during three successive growing seasons using seed material from the previous crop.
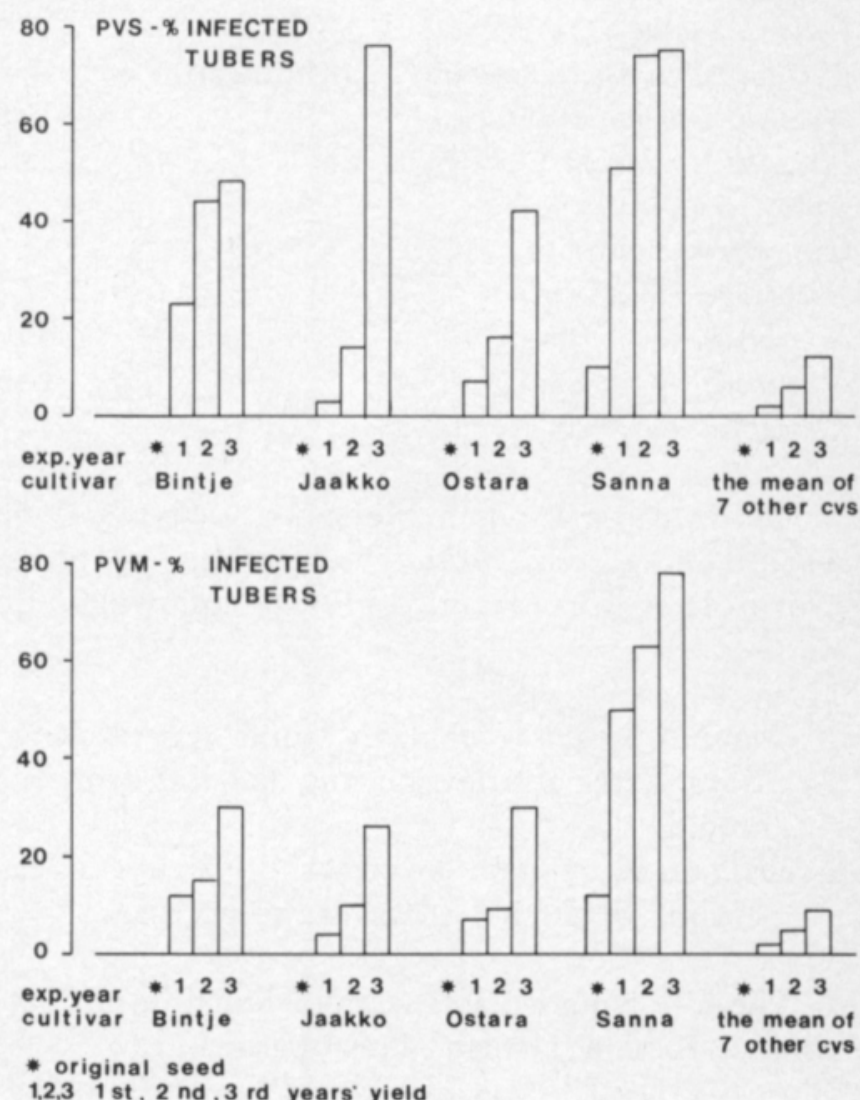
Table 7. Aphid transmission of PVS isolates. Three wingless Myzus persicae aphids were transferred onto each Nicotiana debneyi plant. The acquisition time was $2 \mathrm{~min}$ and the inoculation time was $18-20$ h. Three replicates of 10 test plants were used. For the origin of the isolates see text.

\begin{tabular}{|c|c|c|c|c|c|c|c|}
\hline \multirow{2}{*}{\multicolumn{8}{|c|}{$\%$ of plants infected with PVS }} \\
\hline & & & & & & & \\
\hline SSF1 & SSF4 & SSF6 & SSF7 & SSF8 & SSF10 & SSF14 & SSF15 \\
\hline 13.3 & 0.0 & 6.7 & 6.7 & 10.0 & 26.7 & 30.0 & 36.7 \\
\hline
\end{tabular}

\subsection{Symptoms in test plants and isolate classification}

Most isolates of PVS induced similar symptoms in certain test plants, however some differences were found. Similar symptoms were found in the following host species:

Chenopodium amaranticolor: Chlorotic local lesions $1-2 \mathrm{~mm}$ in diameter in 15-20 days.

C. quinoa: Chlorotic local lesions $1-2 \mathrm{~mm}$ in diameter in $12-20$ days (Fig. $14)$.

Solanum rostratum: Numerous small necrotic local lesions in 20-30 days. Systemically infected leaves showed similar symptoms. Leaf drop of older leaves occurred (Fig. 13).

\section{Datura metel}

Lycopersicon esculentum cv. Kotitomaatti Nicandra physaloides

Physalis floridana

Solanum demissum $\mathrm{Y}$

Gomphrena globosa

Nicotiana clevelandii

N. glutinosa

N. tabacum cv. Samsun

Phaseolus vulgaris cv. Stella

Latent systemic

infection was found.

These plants did not become infected.

Uniform variation in the severity of the symptoms was found in $L$. chilense and L. esculentum cv. Nevskij. According to these symptoms the virus isolates were classified into the following 3 groups:

\section{Group I}

L. chilense: Systemic epinasty, mild vein-clearing and stunting in 10-14 days. Later also leaf-curling and leaf-drop occurred. No necrosis was found.

L. esculentum cv. Nevskij: Latent systemic infection initially; later leafcurling of the oldest leaves; no necrosis.

The following isolates were included in this group:

SSF4, Kaptah (Danish), Prestoperuna Ltd 1976

SSF6, Hja's Tuomas, Hankkija Plant Breeding Institute 1976 
Group II

L. chilense: Systemic epinasty and vein-clearing in 10-14 days; stunting and leaf necrosis starting from the basal leaves in 18-22 days.

L. esculentum cv. Nevskij: Stunting and faint epinasty in 10-15 days; necrosis in the basal leaves in 15-20 days.

The following isolates were included in this group:

SSF1, Jaakko, Tikkurila

1975

SSF3, Pito, Seed Testing Institute

1975

SSF5, Prestoperuna Ltd

1976

SSF9, Record, Hankkija Plant Breeding Institute

1976

SSF13, Veto, Plant Breeding Institute, A.R.C.

1978

SSF16, Saturna, Liminka

1980

SSF17, Posmo, Viikki

1980

SSF18, Eigenheimer, Porvoo

1982

\section{Group III}

L. chilense: Severe systemic epinasty and leaf-curling in 10-14 days; severe foliar necrosis and leaf-drop in 18-22 days.

L. esculentum cv. Nevskij: Leaf-curling and stunting in 10-15 days; necrosis and leaf-drop starting from the basal leaves in 15-20 days (Fig. 15).

The following isolates were included in this group:

SSF2, Saturna, Dutch imported seed

SSF7, Sanna, Plant Breeding Institute, A.R.C.

SSF10, Prevalent, Prestoperuna Ltd

SSF12, Sanna, Plant Breeding Institute, A.R.C.

$N$. debneyi showed the following variation in symptoms between PVS isolates:

All isolates induced systemic vein chlorosis and chlorotic areas between the veins in 20-30 days followed by marginal leaf necrosis in 40-50 days. Large chlorotic rings were caused by the isolates SSF7 and 12 (Fig. 16) and large chlorotic spots by the isolates SSF1, 15 and 18. Chlorotic lesions of equal size were induced by the other isolates (Fig. 17).

Symptom variation between the isolates was minimal. The isolates selected for further studies had the following properties:

SSF1: Severe chlorosis in potatoes; not easily transmitted by aphids.

SSF4: Some "rough" symptoms in potatoes; no aphid transmission was detected.

SSF6: No visible symptoms in potatoes and mild symptoms in the test plants; not easily transmitted by aphids. 
SSF7: Chlorosis in potatoes and chlorotic rings in $N$. debneyi; severe symptoms in $L$. chilense and $L$. esculentum cv. Nevskij; not easily transmitted by aphids.

SSF14: Chlorosis in potatoes and severe symptoms in $L$. chilense and $L$. esculentum cv. Nevskij; readily transmitted by the aphids.

\subsection{Sap properties and virus purification}

\subsubsection{Thermal inactivation point and dilution end point}

The values obtained for the thermal inactivation points of the virus isolates were almost equal and so it was not possible to use this test as a criterium for classification (Table 8).

Table 8. The mean number of lesions on Chenopodium quinoa leaves after inoculation with heated sap of Nicotiana debneyi infected with PVS isolates. Three replications were done.

\begin{tabular}{|c|c|c|c|c|c|}
\hline \multirow[t]{2}{*}{ Temperature in $\mathrm{C}$} & \multicolumn{5}{|c|}{$\begin{array}{l}\text { Lesion number } \\
\text { Isolate }\end{array}$} \\
\hline & SSF1 & SSF4 & SSF6 & SSF7 & SSF14 \\
\hline Unheated & 51.3 & 76.0 & 57.7 & 81.7 & 49.7 \\
\hline 45 & 24.3 & 41.0 & 32.0 & 27.7 & 31.3 \\
\hline 48 & 14.0 & 21.3 & 16.3 & 16.0 & 19.0 \\
\hline 51 & 6.0 & 7.7 & 7.7 & 9.0 & 3.7 \\
\hline 54 & 3.3 & 5.3 & 2.0 & 4.7 & 1.3 \\
\hline 57 & 0.0 & 2.3 & 1.5 & 2.0 & 0.0 \\
\hline 60 & 0.0 & 0.0 & 0.0 & 0.0 & 0.0 \\
\hline 63 & 0.0 & 0.0 & 0.0 & 0.0 & 0.0 \\
\hline
\end{tabular}

The dilution end point values were between $10^{-2}$ and $10^{-3}$. No significant differences in dilution end point values were found but a relationship between them and the thermal inactivation point values was obvious (Table $9)$.

Table 9. The mean number of lesions on Chenopodium quinoa leaves after inoculation with diluted sap of Nicotiana debneyi. Three replications were done.

\begin{tabular}{|c|c|c|c|c|c|}
\hline \multirow[t]{2}{*}{ Dilution } & \multicolumn{5}{|c|}{$\begin{array}{l}\text { Lesion number } \\
\text { Isolate }\end{array}$} \\
\hline & SSF1 & SSF4 & SSF6 & SSF7 & SSF14 \\
\hline Undiluted & 44.3 & 69.0 & 47.3 & 74.7 & 36.0 \\
\hline $10^{-1}$ & 11.0 & 19.7 & 13.7 & 17.0 & 8.3 \\
\hline $10^{-2}$ & 1.3 & 3.7 & 1.3 & 2.0 & 0.7 \\
\hline $10^{-3}$ & 0.0 & 0.0 & 0.0 & 0.0 & 0.0 \\
\hline $10^{-4}$ & 0.0 & 0.0 & 0.0 & 0.0 & 0.0 \\
\hline
\end{tabular}




\subsubsection{Electron microscopy and purification}

Numerous virus particles were seen in negatively stained preparates of PVS infected plant sap. A length of c. $650 \mathrm{~nm}$ and a diameter of $12 \mathrm{~nm}$ were typical of the virus particles. The particles were straight or slightly flexuous and usually occurred separately (Fig. 60, page 251). Broken particles or particles joined from end to end were seldom seen.

In virus purification $L$. esculentum $\mathrm{cv}$. Nevskij proved to be the host in which the highest virus concentration occurred. The purity of the virus preparate was, however, best when it was prepared from potato leaves. A partially purified preparate from $L$. esculentum $\mathrm{cv}$. Nevskij contained the highest amount of impurities.

In density gradient centrifugation the virus moved to one narrow band. In electron microscope preparates it was found to contain homogeneous and mainly intact particles. The following maximum yields of purified virus were obtained for the PVS isolates:

$\begin{array}{ll}\text { SSF1 from } S . \text { tuberosum cv. Pito } & 18 \mathrm{mg} / \mathrm{kg} \\ \text { SSF4 from } N \text {. debneyi } & 21 " \\ \text { SSF6 from } N \text {. debneyi } & 19 " \\ \text { SSF7 from } N \text {. debneyi } & 27 " \\ \text { SSF7 from } L \text {. esculentum cv. Nevskij } & 31 " \\ \text { SSF14 from } N \text {. debneyi } & 22 ” \\ \text { SSF14 from } L \text {. esculentum cv. Nevskij } & 28 ”\end{array}$

All purified virus preparates were infectious after being stored for 2 years in $0.05 \mathrm{M}$ borate buffer which contained $0.02 \%$ sodium azide at $\mathrm{pH} 8.2$.

\subsection{Serological properties}

\subsubsection{Homologous titers of the antisera}

All of the purified PVS isolates proved to be good or moderately good immunogens (Table 10).

Reasonably high titers for serological tests were reached in 3-5 weeks. The titers of certain isolates remained somewhat lower than those of some others in spite of repeated injections. The titers were stable for several weeks. Non-specific titers were $1 / 8$ or lower in the chloroplast agglutination and microprecipitin tests.

\subsubsection{Heterologous titers of the antisera}

All Finnish PVS isolates reacted strongly against any antisera produced in this study. The lowest heterologous titer as determined by the microprecipitin test was $1 / 128$. The maximum heterologous reaction was normally found 
Table 10. Injection and sampling schedules of antiserum production by PVS isolates and titers as determined by the microprecipitin test. $\rightarrow=$ injection.

\begin{tabular}{|c|c|c|c|c|c|}
\hline \multirow{2}{*}{$\begin{array}{l}\text { Time } \\
\text { in weeks }\end{array}$} & \multicolumn{5}{|c|}{ Virus isolates and their titers } \\
\hline & SSF1 & SSF4 & SSF6 & SSF7 & SSF14 \\
\hline 0 & $\rightarrow$ & $\rightarrow$ & $\rightarrow$ & $\rightarrow$ & $\rightarrow$ \\
\hline 1 & $\rightarrow$ & $\rightarrow$ & $\rightarrow$ & $\rightarrow$ & $\rightarrow$ \\
\hline 2 & $\rightarrow 1 / 256$ & $\rightarrow$ & $\rightarrow$ & $\rightarrow$ & $\rightarrow$ \\
\hline 3 & $\rightarrow$ & $\rightarrow 1 / 256$ & $\rightarrow 1 / 256$ & $\rightarrow 1 / 256$ & $\rightarrow 1 / 1024$ \\
\hline 4 & & & & & \\
\hline 5 & $1 / 1024$ & $1 / 1024$ & $\rightarrow 1 / 256$ & $1 / 512$ & $1 / 2048$ \\
\hline 6 & $\rightarrow$ & & & & \\
\hline 7 & & $\rightarrow 1 / 1024$ & $\rightarrow 1 / 1024$ & $\rightarrow 1 / 256$ & $\rightarrow 1 / 1024$ \\
\hline 8 & $1 / 2048$ & & & & \\
\hline 9 & & $1 / 2048$ & $1 / 1024$ & $1 / 512$ & $1 / 2048$ \\
\hline 10 & $1 / 2048$ & & & & \\
\hline 11 & & $1 / 1024$ & $1 / 1024$ & $1 / 512$ & $1 / 2048$ \\
\hline 12 & $\rightarrow 1 / 1024$ & & & & \\
\hline 13 & & & & & \\
\hline 14 & $1 / 2048$ & $\rightarrow 1 / 1024$ & $\rightarrow 1 / 512$ & $\rightarrow 1 / 256$ & $\rightarrow 1 / 1024$ \\
\hline 15 & & & & & \\
\hline 16 & $1 / 2048$ & $1 / 2048$ & $1 / 1024$ & $1 / 512$ & $1 / 2048$ \\
\hline 17 & & & & & \\
\hline 18 & $\rightarrow 1 / 1024$ & $1 / 1024$ & $1 / 1024$ & $1 / 256$ & $1 / 2048$ \\
\hline 19 & & & & & \\
\hline 20 & & $\rightarrow 1 / 1024$ & $1 / 512$ & & \\
\hline 21 & $1 / 1024$ & & & & \\
\hline 22 & & $1 / 2048$ & & & \\
\hline 23 & & & & & \\
\hline 24 & $\rightarrow 1 / 1024$ & $1 / 1024$ & & & \\
\hline 25 & & & & & \\
\hline 26 & $1 / 2048$ & & & & \\
\hline 27 & & & & & \\
\hline 28 & $1 / 1024$ & & & & \\
\hline
\end{tabular}

when the antigen concentration was $30 \mu \mathrm{g} / \mathrm{ml}$ as determined by the microprecipitin test. The isolates SSF1, SSF4 and SSF6 were serologically closely related but the isolates SSF7 and SSF14 differed significantly from the main group and from each other (Table 11).

Remarkable variation in the heterologous titers of the foreign antisera was

Table 11. Assessment of serological relationships between the PVS isolates by the microprecipitin test.

\begin{tabular}{lrrrrr}
\hline \multirow{2}{*}{ Antigen } & \multicolumn{5}{c}{ Antisera and their titers } \\
& SSF1 & SSF4 & SSF6 & \multicolumn{1}{c}{ SSF7 } & SSF14 \\
\hline SSF1 & $1 / 2048$ & $1 / 1024$ & $1 / 512$ & $1 / 256$ & $1 / 256$ \\
SSF4 & 1024 & 2048 & 512 & 512 & 512 \\
SSF6 & 1024 & 1024 & 1024 & 256 & 512 \\
SSF7 & 512 & 512 & 512 & 512 & 256 \\
SSF14 & 256 & 256 & 256 & 128 & 2048 \\
\hline
\end{tabular}


Table 12. The highest titers of 3 indigenous and 4 foreign antisera used in determining the Finnish type isolates of PVS.

\begin{tabular}{lccccccc}
\hline \multirow{2}{*}{ Antigen } & \multicolumn{7}{c}{ Antisera and their titers } \\
& SSF1 & SSF7 & SSF14 & Danish & Estonian & Polish & Hungarian \\
\hline SSF1 & $1 / 2048$ & $1 / 256$ & $1 / 256$ & $1 / 2048$ & $1 / 1024$ & $1 / 128$ & $1 / 256$ \\
SSF7 & 512 & 512 & 256 & 512 & 256 & $1 / 32$ & $1 / 64$ \\
SSF14 & 256 & 128 & 2048 & 256 & 256 & $1 / 64$ & $1 / 64$ \\
\hline
\end{tabular}

found. All the antisera reacted with the Finnish PVS isolates but only the Danish and the Estonian antisera were suitable for routine work. The foreign antisera were more closely related to the isolates SSF1, 4 and 6 than to the others (Tables 11 and 12).

\subsubsection{Immunogenesis of the degraded antigen}

Potato virus S, isolate SSF1, degraded with pyrrolidine and then injected into rabbits, gave rise to antibody formation. The titer of the antiserum rose slowly and repeated injections were needed to keep it at a standard level (Fig. 11). The highest titer of the antiserum was $1 / 32$ as determined with the agar gel double diffusion test and it was reached 4 weeks after the first injection. The same level was obtained again later but some of the reaction specificity was lost. In comparison, the titers of the other degraded PVSproteins were as follows: SSF $4=1 / 32$, SSF7 $=1 / 16$, SSF14 $=1 / 8$. The ideal protein concentration in the titers was $125 \mu \mathrm{g}$ or $250 \mu \mathrm{g} / \mathrm{ml}$. A higher concentration was responsible for a broader, diffuse precipitin line or a double one and with a lower concentration only a sharp, weakly visible precipitin line developed.

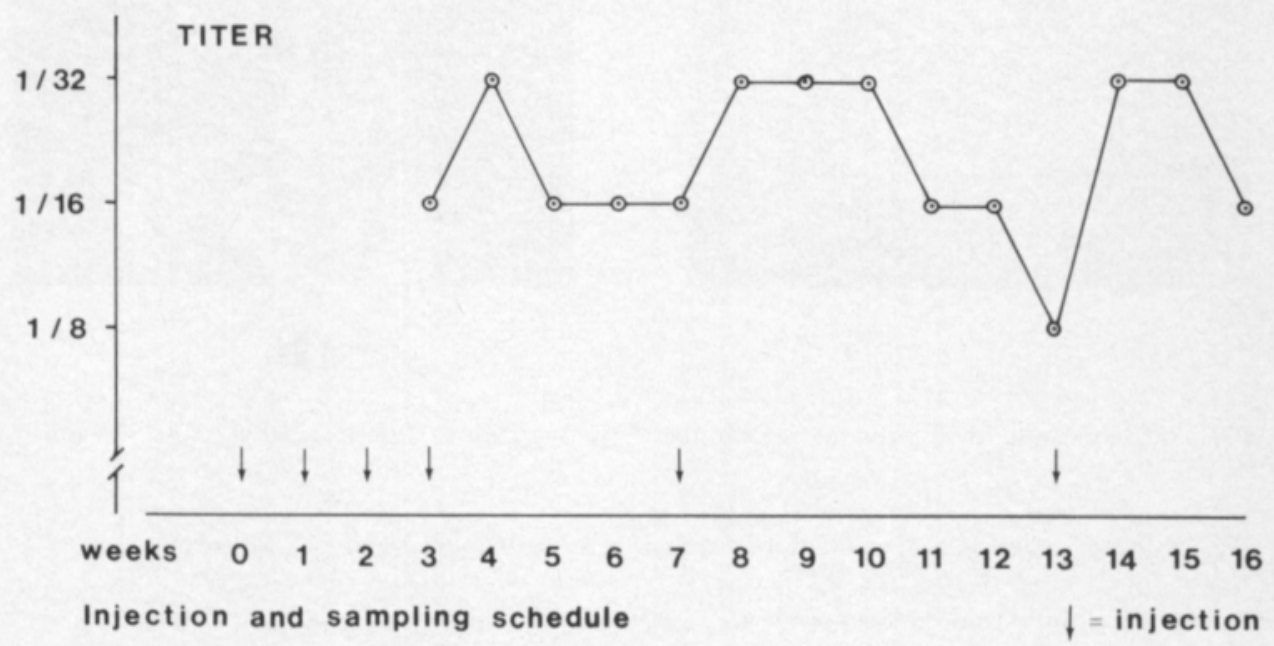

Fig. 11. PVS-D-antiserum production procedure and the titer of the antiserum as determined by the double diffusion test during the course of the programme. 


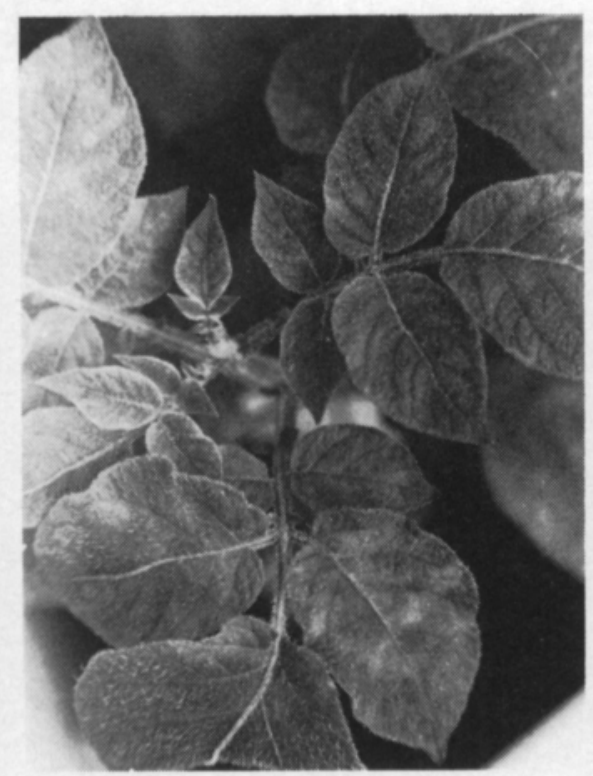

Fig. 12

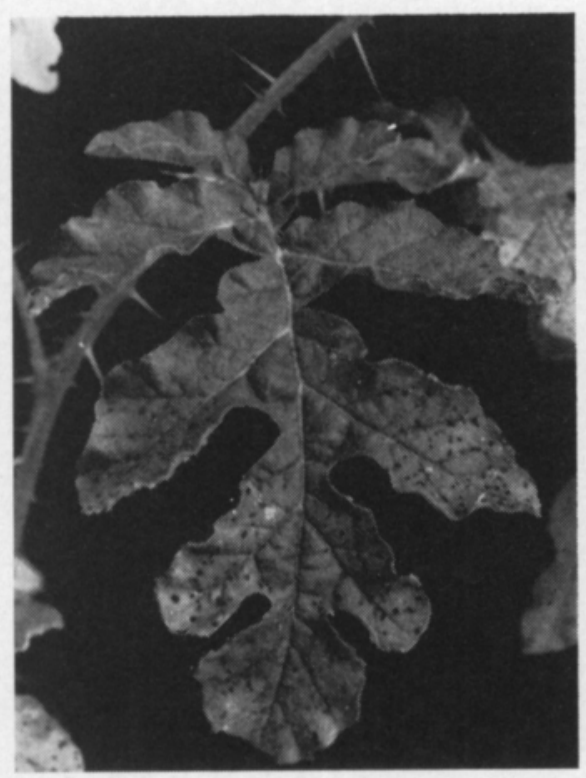

Fig. 13

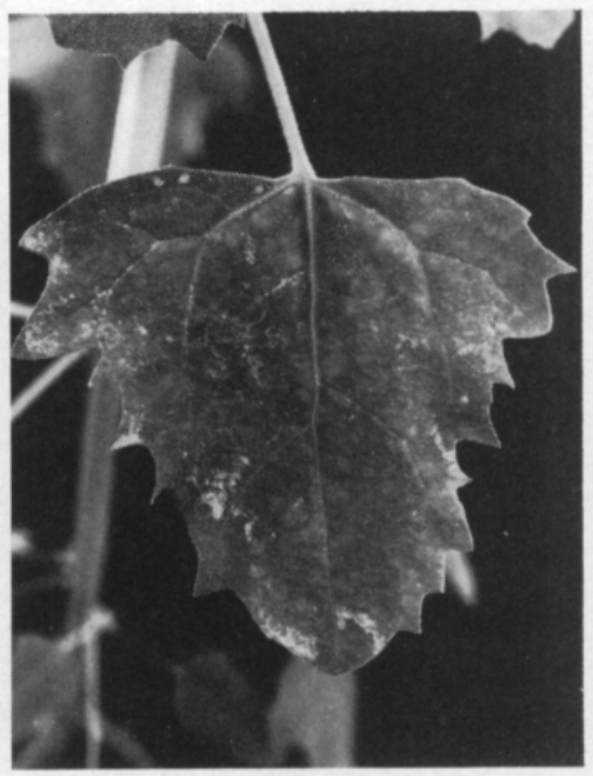

Fig. 14

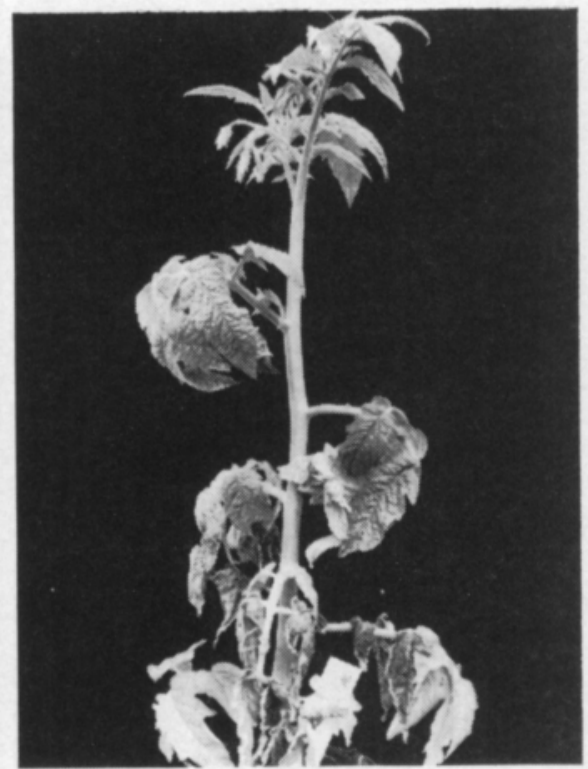

Fig. 15

Fig. 12. Chlorotic spots between the veins of the leaves of potato cv. Pito infected with the PVS isolate SSF3.

Fig. 13. Systemic necrotic spots in Solanum rostratum leaves induced by all PVS isolates.

Fig. 14. Local diffuse chlorotic lesions in Chenopodium quinoa leaves induced by all PVS isolates.

Fig. 15. Systemic leaf curling and necrosis starting from the basal leaves of Lysopersicon esculentum cv. Nevskij as caused by the PVS isolate, SSF12. 


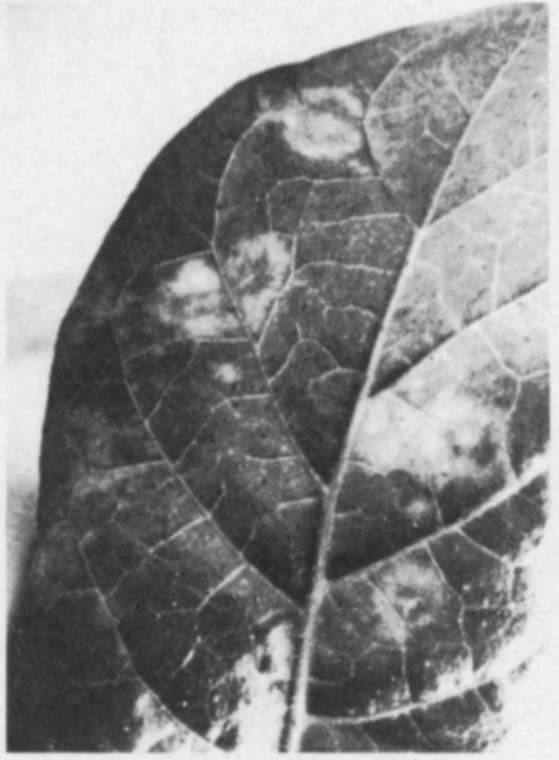

Fig. 16

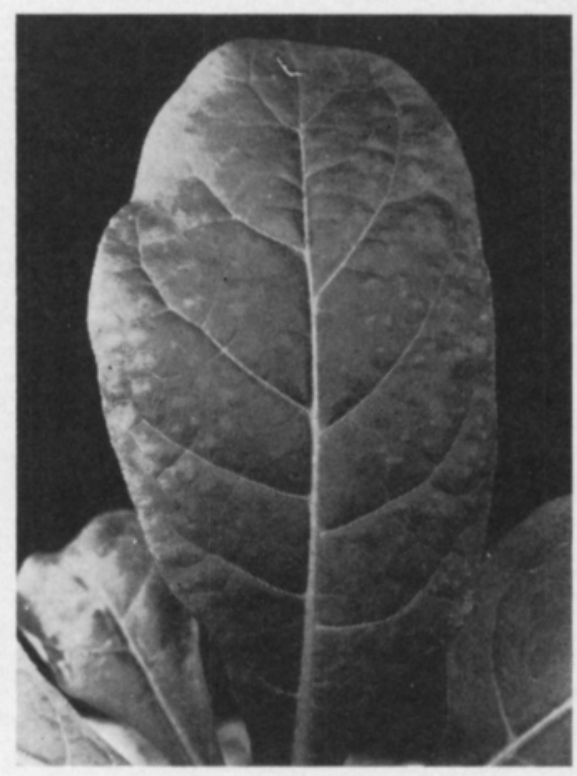

Fig. 17

Figs. 16 and 17. Large systemic chlorotic rings or chlorotic + necrotic spots and vein mosaic in Nicotiana debneyi infected with PVS isolate SSF7 (Fig. 16) and isolate SSF14 (Fig. 17).

\section{Potato virus $\mathrm{M}(\mathrm{PVM})$}

Potato virus M, R/1:2.4/5.4:E/E:S/Ap (PROLL et al. 1981) is distributed worldwide in cultivated potatoes and diseases caused by it have been reported since the 1920's (SCHULZ \& FOLSOM 1923). The virus itself, however, was not studied until the 1950's (BAGNALL et al. 1956, ROZENDAAL \& van SLOGTEREN 1958, BRANDES et al. 1959, WETTER \& VÖLK 1960, ROSS 1968, KOWALSKA 1978, PROLL et al. 1978, PROLL \& RICHTER 1979, PROLL et al. 1981). The virus has several synonyms, the most well-known of which are Kartoffel-K-Virus, Kartoffel-Rollmosaik-Virus, Potato interveinal mosaic virus, Potato leaf rolling mosaic virus, Potato paracrinkle virus, Potato virus E, Solanum virus 7 and Solanum virus 11 (WETTER 1972).

Potato virus $M$ has straight to slightly curved filamentous particles c. 650 $\times 12 \mathrm{~nm}$ (BRANDES et al. 1959). It is sap and aphid transmitted (WETTER 1972). Its host range is narrow with most species belonging to the Solanaceae (BAGNALL et al. 1956, BRANDES et al. 1959, ROSS 1968) but susceptible species in a few other families have also been found. Suitable hosts among them are: Datura metel (KAHN \& MONROE 1970); Gomphrena globosa (BAGNALL et al. 1959); Phaseolus vulgaris (HIRUKI 1970, HORVATH 1972) and some Chenopodium species (HORVATH \& de BOKX 1972).

The economical importance of the virus is restricted to the damage it causes to potatoes. Remarkable variation in disease severity occurs among different potato cultivars and different virus strains or isolates (BEEMSTER \& ROZENDAAL 1972). Examples of very susceptible cultivars are Arran Victory 
(BRANDES \& WETTER 1963) and Uran (CHRZANOWSKA 1976). In these cultivars the virus causes severe stunting and leaf-rolling symptoms. Losses in tuber yields of up to $60 \%$ have been reported (CHRZANOWSKA 1976). In most potato cultivars the virus causes mild disease with yield losses of between 5 and $20 \%$ (O'BRIEN \& RICH 1976). In diseases caused by a mixture of several viruses PVM greatly increases the level of disease in the potato (HUNNIUS 1976).

\subsection{Occurrence and symptomology in potatoes}

Potato virus $\mathrm{M}$ was rather common in commercial seed potatoes in Finland tested in 1975 and 1976. Also the potatoes produced at our plant breeding stations were severely infected with the virus. In imported seed potato the virus was seldom detected at that time (Table 6).

All of the potato cultivars that were tested-in field experiments were susceptible to the virus but large differences in disease severity between the cultivars were found (Fig. 10). The natural rate of infection among the cultivars in the field reached the following levels during the third experimental year when the seed potatoes used were obtained from the previous crop: Sanna $79 \%$ PVM-infected tubers, Veto $49 \%$, Bintje, Ostara and Pito $30 \%$, Hankkija's Tuomas $29 \%$. The most tolerant cultivars were Posmo and Saturna with $1 \%$ infection and Hankkija's Timo with $4 \%$ infection. In crops of other cultivars between 7 and $10 \%$ of the tubers were detected as being infected with PVM.

Potato virus $\mathrm{M}$ induced severe stunting and leaf-rolling symptoms in the cultivars Bintje, Hankkija's Tuomas and Puikelo (Figs. 19 and 22, page 223). On average the tuber yield of infected plants was about $50 \%$ lower than that of healthy plants. The main reason for the yield losses was smaller tuber size. The symptoms typical of PVM were detectable in these cultivars even in cases of severe mixed infections with potato virus Y (Fig. 23). Visible leaf-rolling symptoms were also detected in the following cultivars: Prevalent, Record, Sanna, Hankkija's Tanu and Hankkija's Timo. In the other cultivars the virus was latent or only mild interveinal mosaic or some leaf-rolling was observed (Fig. 20).

\subsection{Symptoms in test plants and isolate classification}

All 15 isolates studied could be transmitted both mechanically and by aphids to $L$. esculentum cv. Kotitomaatti. The infection remained latent but could be detected serologically within $8-12$ days after transmission. The virus induced symptoms in the following test plants:

Chenopodium quinoa: Variable number of chlorotic local lesions in 10-14 days. 
Datura metel: A few chlorotic local lesions in $8-10$ days when isolates MSF3, 6 and 10 were used as inoculum.

Lycopersicon chilense: Systemic symptoms only: leaf-curling, stunting and necrosis in 10-15 days depending on the isolate (Fig. 24). No necrosis was caused by the isolates MSF1, 2, 5, 12 and 15; partial vein necrosis was caused by the isolates MSF3, 4, 6, 9 and 13 and severe leaf and top necrosis by the isolates MSF7, 8, 10, 11 and 14 .

Nicotiana debneyi: Non-uniform large necrotic local lesions in 9-12 days were caused by the isolates MSF5, 6 and 11 .

Phaseolus vulgaris cv. Red Kidney: Some faint necrotic local lesions were initiated in 5-7 days from all isolates.

Solanum rostratum: Systemic leaf-curling, stunting and vein necrosis in 12-18 days followed by leaf and top necrosis. The severity of the symptoms caused by the different isolates were comparable to those seen in L. chilense (Fig. 21).

For further studies isolates of $L$. chilense and S. rostratum were classified into the following categories according to their symptomology:

I Mild isolates:

MSF1, Hja's Tuomas, Hankkija Plant Breeding Institute 1976

MSF2, Pito, The University Farm, Viikki

MSF5, Veto, Plant Breeding Institute, A.R.C.

MSF12, Prevalent, Pyhtää

MSF15, Provita, Liljendal

II Moderate isolates:

MSF3, Kaptah, Danish imported seed

MSF4, Hja's Timo, Hankkija Plant Breeding Institute

MSF6, Pito, Maaninka

MSF9, Pito, The University Farm, Viikki

MSF13, Hja's Tuomas, The University Farm, Viikki

III Severe isolates:

MSF7, Saturna, Prestoperuna Ltd

MSF8, Sanna, Plant Breeding Institute, A.R.C.

MSF10, Record, Loppi

MSF11, Bintje, The University Farm, Viikki

1980

MSF14, Sanna, Plant Breeding Institute, A.R.C.

1980

\subsection{Sap properties and virus purification}

Thermal inactivation point and the dilution end point values for PVM isolates were determined using a host species ( $L$. esculentum cv. Kotitomaatti) that developed a latent systemic infection because no locally infected host showed clear symptoms. The assay plants were tested serologi- 
Table 13. The thermal inactivation point (TIP) and the dilution end point (DEP) values for 5 PVM isolates from infected sap of Lycopersicon esculentum cv. Kotitomaatti plants.

\begin{tabular}{llllll}
\hline & MSF1 & MSF3 & $\begin{array}{c}\text { Virus isolates } \\
\text { MSF5 }\end{array}$ & MSF7 & MSF8 \\
\hline TIP C & 64 & 67 & 64 & 67 & 67 \\
DEP & $10^{-2}$ & $10^{-3}$ & $10^{-2}$ & $10^{-3}$ & $10^{-3}$ \\
\hline
\end{tabular}

cally 3 weeks after being mechanically inoculated with treated plant sap. The variation in TIP and DEP values was not great; the former being between 64 and $67 \mathrm{C}$ and the latter between $10^{-2}$ and $10^{-3}$ (Table 13 ).

Numerous virus particles were seen in electron micrographs of negatively stained preparates made from systemically infected potato and tomato sap. Most of the straight or slightly curved particles were equal in size at c. $650 \times$ $12 \mathrm{~nm}$ (Fig. 61, page 251). In purified virus EM preparates the same particle properties could be seen and c. $70 \%$ of the particles had kept their normal length.

A virus preparate made from frozen leaves of $L$. esculentum cv. Kotitomaatti, moved to one narrow band in linear sucrose gradients with density gradient centrifugation. The purified virus preparate remained infective for at least 2 years in $0.05 \mathrm{M}$ borate buffer containing $0.02 \% \mathrm{NaN}_{3}$ at $\mathrm{pH}$ 8.2. The highest yields of purified virus were obtained from the following isolates as follows: MSF1 $=30 \mathrm{mg}$, MSF3 $=42 \mathrm{mg}$, MSF5 $=35 \mathrm{mg}$, MSF7 $=$ $48 \mathrm{mg}$ and MSF8 $=35 \mathrm{mg} / \mathrm{kg}$ leaves.

\subsection{Serological properties}

\subsubsection{Homologous titers of the antisera}

The PVM isolates used for antiserum production were found to be good immunogens. The titers of the antisera reached a level high enough for serological tests in 3-9 weeks (Table 14) but variation among the titers was found. The titers remained at the same level for several weeks after the last injection. The non-specific titer in the microprecipitin and in the chloroplast agglutination tests was $1 / 8$ or lower.

\subsubsection{Heterologous titers of the antisera}

All of the PVM isolates were serologically closely related so that no serological strains could be detected (Table 15). The isolates MSF1 and MSF3 and similarly MSF7 and MSF8 were serologically almost identical. The highest titers were obtained when an antigen concentration of $30-120 \mu \mathrm{g} / \mathrm{ml}$ was used.

The titers of foreign antisera in reactions with Finnish PVM isolates were lower than those obtained with domestic antisera. However, all foreign antisera reacted strongly to all of the isolates studied (Table 15). 
Table 14. Immunization and sampling schedules, and the homologous titers of PVM isolates as obtained with the microprecipitin test. $\rightarrow=$ injection.

\begin{tabular}{|c|c|c|c|c|}
\hline \multirow[b]{2}{*}{$\begin{array}{l}\text { Time } \\
\text { in weeks }\end{array}$} & \multicolumn{4}{|c|}{ Virus isolate and titer } \\
\hline & MSF1 & MSF3 & MSF7 & MSF8 \\
\hline 0 & $\rightarrow$ & $\rightarrow$ & $\rightarrow$ & $\rightarrow$ \\
\hline 1 & $\rightarrow$ & $\rightarrow$ & $\rightarrow$ & $\rightarrow$ \\
\hline 2 & $\rightarrow$ & $\rightarrow$ & $\rightarrow$ & $\rightarrow$ \\
\hline 3 & $\rightarrow 1 / 256$ & $\rightarrow 1 / 512$ & $\rightarrow 1 / 512$ & $\rightarrow 1 / 256$ \\
\hline \multicolumn{5}{|c|}{ 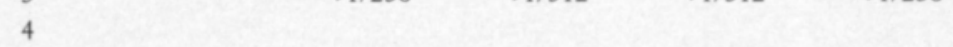 } \\
\hline 5 & $1 / 1024$ & $1 / 2048$ & & \\
\hline 6 & & & $\rightarrow 1 / 2048$ & $\rightarrow 1 / 512$ \\
\hline 7 & $1 / 1024$ & $1 / 2048$ & & \\
\hline 8 & & & $1 / 4096$ & $1 / 512$ \\
\hline \multicolumn{5}{|l|}{9} \\
\hline 10 & $\rightarrow 1 / 512$ & $\rightarrow 1 / 1024$ & $\rightarrow 1 / 2048$ & $\rightarrow 1 / 256$ \\
\hline \multicolumn{5}{|l|}{11} \\
\hline 12 & $1 / 1024$ & $1 / 2048$ & $1 / 4096$ & $1 / 1024$ \\
\hline \multicolumn{5}{|l|}{13} \\
\hline 14 & $\rightarrow 1 / 1024$ & $\rightarrow 1 / 1024$ & $1 / 4096$ & $1 / 1024$ \\
\hline \multicolumn{5}{|l|}{15} \\
\hline 16 & & & $1 / 2048$ & $1 / 1024$ \\
\hline 17 & $1 / 2048$ & $1 / 2048$ & & \\
\hline 18 & & & $\rightarrow 1 / 2048$ & $\rightarrow 1 / 512$ \\
\hline 19 & $1 / 1024$ & $1 / 2048$ & & \\
\hline 20 & & & $1 / 4096$ & $1 / 1024$ \\
\hline \multicolumn{5}{|l|}{21} \\
\hline 22 & $\rightarrow 1 / 1024$ & & $1 / 4096$ & $1 / 1024$ \\
\hline \multicolumn{5}{|c|}{ - } \\
\hline 24 & $1 / 1024$ & & $1 / 2048$ & $1 / 512$ \\
\hline \multicolumn{5}{|l|}{25} \\
\hline 26 & $1 / 1024$ & & & \\
\hline
\end{tabular}

Table 15. Heterologous titers of Finnish and foreign antisera tested against 4 PVM isolates as determined with the microprecipitin test.

\begin{tabular}{lllllllll}
\hline \multirow{2}{*}{ Antigen } & \multirow{2}{*}{ MSF1 } & MSF3 & MSF7 & \multicolumn{2}{c}{ Antisera and their titers } \\
& & MSF8 & Danish & Estonian & Polish & Hungarian \\
\hline MSF1 & $1 / 1024$ & $1 / 1024$ & $1 / 2048$ & $1 / 512$ & $1 / 512$ & $1 / 512$ & $1 / 128$ & $1 / 128$ \\
MSF3 & $1 / 1024$ & $1 / 2048$ & $1 / 2048$ & $1 / 512$ & $1 / 512$ & $1 / 512$ & $1 / 128$ & $1 / 256$ \\
MSF7 & $1 / 1024$ & $1 / 512$ & $1 / 4096$ & $1 / 1024$ & $1 / 1024$ & $1 / 512$ & $1 / 256$ & $1 / 256$ \\
MSF8 & $1 / 512$ & $1 / 1024$ & $1 / 4096$ & $1 / 1024$ & $1 / 1024$ & $1 / 1024$ & $1 / 512$ & $1 / 512$ \\
\hline
\end{tabular}

\subsubsection{Immunogenesis of the degraded antigen}

A pyrrolidine degraded antigen (MSF7) gave rise to antibody formation in rabbits. The titer of the antiserum rose slowly, however, and repeated injections were needed to keep it at the highest level. The highest titer obtained, as determined by an agar gel double diffusion test, was $1 / 64$ and it 


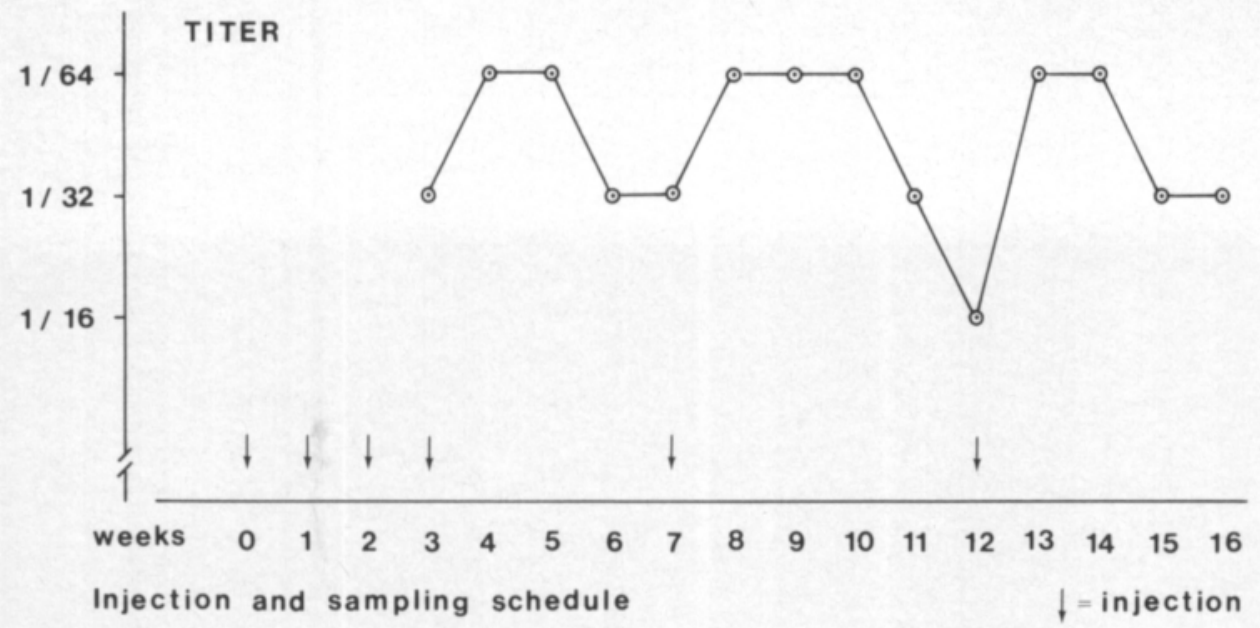

Fig. 18. PVM-D-antiserum production procedure and the titer of the antiserum as determined by the double diffusion test during the course of programme.

initially occurred 5 weeks after the first injection. The same titer level was also reached later in the immunization procedure, however some of the reaction specificity was lost in the course of the program (Fig. 18). The antiserum reacted similarly against all of the other PVM isolates studied. The most suitable antigen concentration for titer determination was c. $0.25 \mathrm{mg} /$ $\mathrm{ml}$. A higher concentration resulted in broad or double precipitin lines, and a lower concentration led to a weakly visible line.

Figs. 19 and 22. Stunting and "leaf rolling" symptoms in potato cvs. Hja's Tuomas (Fig. 19) and Bintje (Fig. 22) infected with PVM.

Fig. 20. Rugosity and chlorotic lesions in potato cv. Pito infected with PVM.

Fig. 21. Stunting and systemic vein necrosis in Solanum rostratum infected with PVM isolate MSF8.

Fig. 23. Mixed infection of PVM and PVY in potato cv. Hja's Tuomas. Symptoms typical of both the viruses are clearly visible.

Fig. 24. Stunting, leaf-curling and leaf necrosis in Lycopersicon chilense infected with PVM isolate MSF10. 


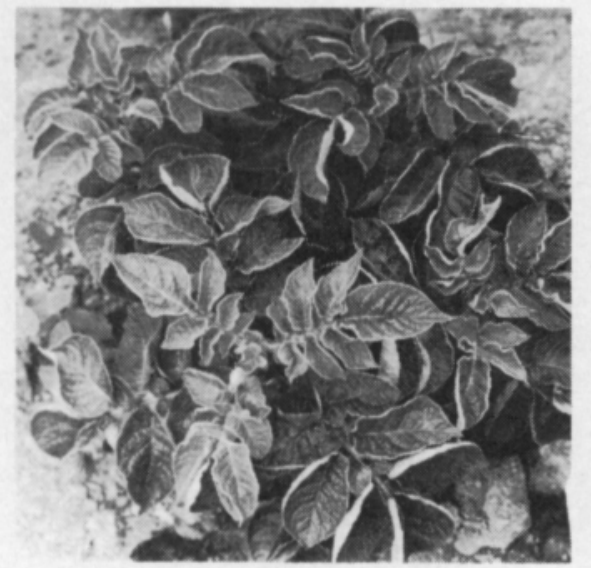

Fig. 19

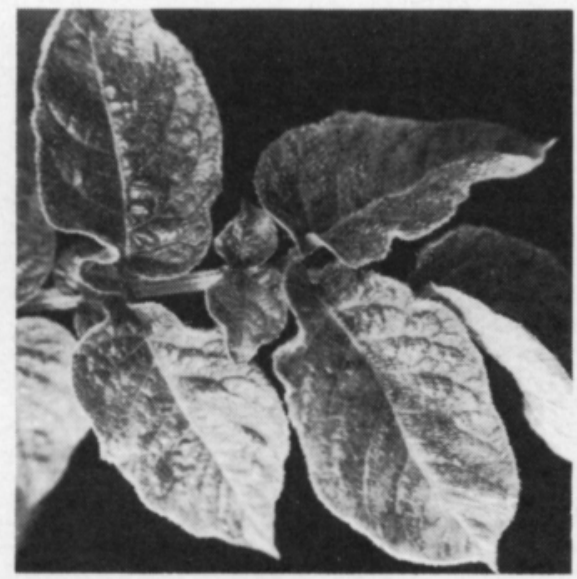

Fig. 20

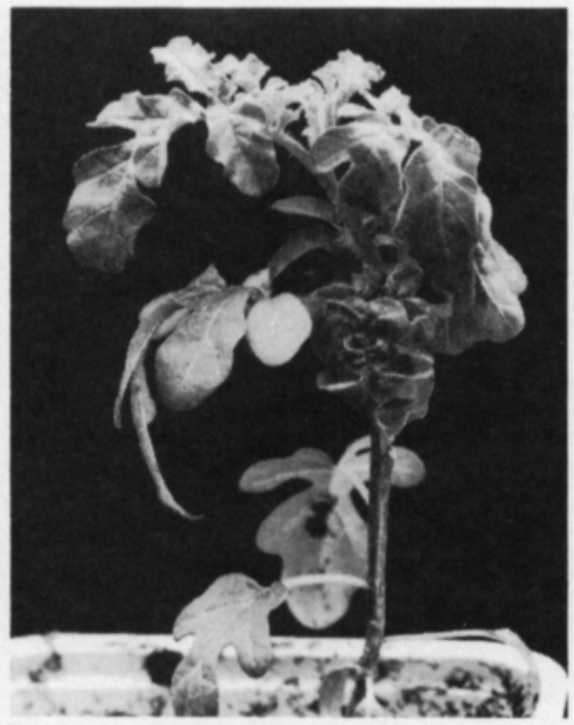

Fig. 21

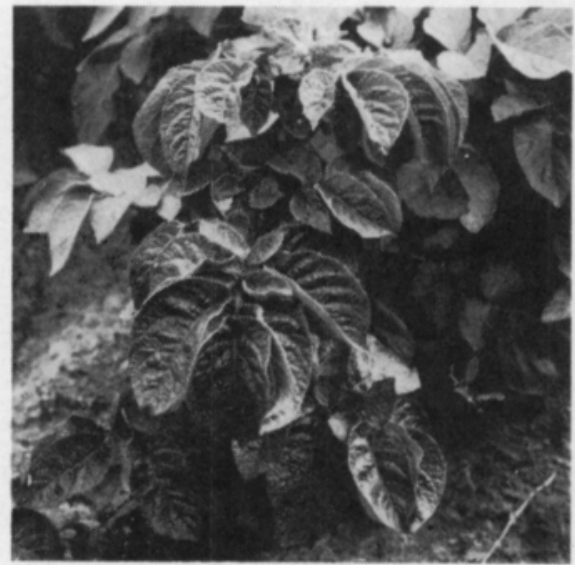

Fig. 22

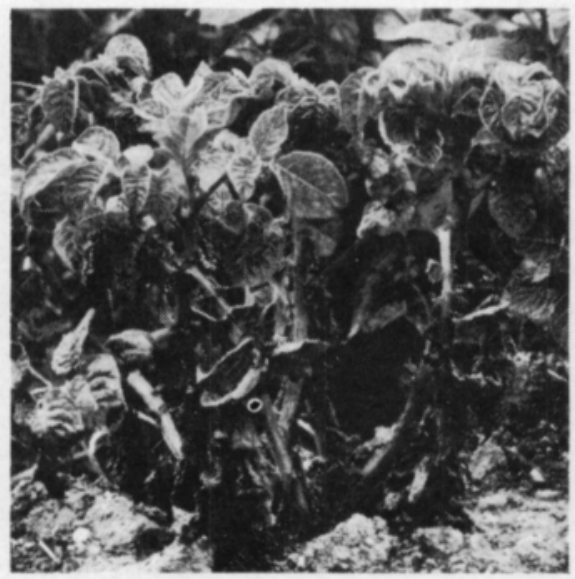

Fig. 23

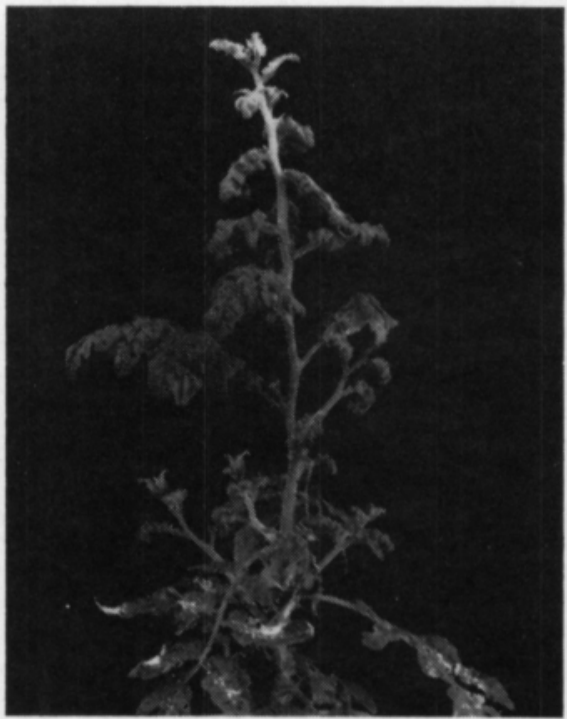

Fig. 24 


\section{Potato virus Y (PVY)}

Potato virus $\mathrm{Y}, \mathrm{R} / 1: 3 / 6: \mathrm{E} / \mathrm{E}: \mathrm{S} / \mathrm{Ve} / \mathrm{Ap}$, first described by SMITH (1931), is distributed worldwide in cultivated potatoes. The following selected synonyms have been used for the virus or the diseases it induces in potatoes: Potato rugose mosaic (SCHULTZ \& FOLSOM 1923), Potato acropetal necrosis virus, Potato severe mosaic virus, Marmor upsilon, Solanum virus 2, Tobacco vein-banding virus (de BOKX \& HUTTINGA 1981). The names "Potato virus C" (BALD \& NORRIS 1945) and "Tobacco veinal necrosis" (SMITH \& DENNIS 1940 , RICHARDSON 1958) refer to the strains $\mathrm{Y}^{\mathrm{c}}$ and $\mathrm{Y}^{\mathrm{n}}$, respectively.

The virus has long flexous particles c. $730 \times 11 \mathrm{~nm}$. It is easily transmitted mechanically to a narrow range of hosts and it is transmitted by many aphid species non-persistently (KENNEDY et al. 1962, van HOOF 1980, de BOKX \& HUTTINGA 1981). In addition to potatoes, the virus causes economically important diseases in peppers, tobacco and tomatoes (de BOKX \& HUTTINGA 1981).

In potatoes, the differences between primary and secondary symptoms are often indistinct. Typical mild primary symptoms include necrotic rings and lesions, and leaf yellowing followed by mottle or mosaic. The virus may also induce severe primary symptoms, such as necrotic spots and stripes, vein necrosis, "leaf drop streak" and sometimes even premature death. Secondary symptoms vary from mild mottling to premature death of the plants but the most typical symptoms are rugosity, chlorosis, vein and leaf necrosis and "leaf drop streak". The degree of symptom severity in potatoes is primarily a result of the interaction between the virus strains and the potato cultivars. The PVY strain $\mathrm{Y}^{\mathrm{n}}$ is milder than the $\mathrm{Y}^{\circ}$ strain, which often induces necrosis (DARBY et al. 1951, BEEMSTER \& ROZENDAAL 1972, O’BRIEN \& RICH 1976, WEIDEMANN 1981).

Potato virus Y decreases the yield of infected potatoes from 10 to $80 \%$, depending on the virus strain, the potato cultivar and the time of infection (BALD 1945, ARENZ \& HUNNIUS 1959, REESTMAN 1970, van der ZAAG 1977). When the tuber yield is about $40 \mathrm{tn} / \mathrm{ha}$, every $1 \%$ of infected plants causes a reduction in yield from between 0.54 and $0.61 \%$ (BORCHART et al. 1964). The virus is transmitted to the tubers of all the plants that have secondary infections (de BOKX \& HUTTINGA 1981).

$\mathrm{PVY}^{\circ}$ strains are distributed worlwide: $\mathrm{Y}^{\mathrm{n}}$ strains occur in Europe including the USSR, parts of Africa and South America; $\mathrm{Y}^{\mathrm{c}}$ strains are rather rare and probably occur in Australia, India and some parts of Europe (BAWDEN 1936, SMITH \& DENNIS 1940, RICHARDSON 1958, KAHN \& MONROE 1963, de BOKX \& HUTTINGA 1981).

The host range of about 60 species is mainly limited to the Solanaceae but some members of the Amaranthaceae, Chenopodiaceae and Leguminosae are also susceptible (MUNRO 1955, HORVATH 1964, THORNBERRY 1966, SCHMELZER 1967). The most suitable local lesion hosts are A6-hybrid (KÖHLER 1953), S. chacoense (de BOKX 1974) and S. demissum Y (CHRZANOWSKA et al. 1977). N. tabacum cvs. Samsun and White Burley are useful in differentiating $\mathrm{Y}^{\circ}$ and $\mathrm{Y}^{\mathrm{n}}$ strains (KLINKOWSKI \& SCHMELZER 
1957, 1960). Moreover these test plants are suitable hosts for virus purification (HUTTINGA 1973).

Potato virus Y could be identified serologically as early as the 1950's (CREMER 1952) but the identification results were unreliable (BARTELS 1957) until the late 1970's when the ELISA test began to be used (GUGERLI 1978, MAAT \& de BOKX 1978).

\subsection{Potato symptomology and virus transmission}

Potato virus $\mathrm{Y}$ was very common and the cause of severe viral diseases in Finnish potatoes until the end of the 1970's, when healthy seed potatoes became commonly available and they started to be used by many farmers (BRUMMER 1946, POHJAKALLIO et al. 1961, SEPPÄNEN 1972, YLLÖ 1975). Also recent important Finnish potato cultivars such as Pito have rapidly lost their high yielding capacity when infected with PVY (SEPPÄNEN 1974, YLLÖ 1975 ) and this has maintained infection sources for the virus.

PVY was rather common in commercial seed lots tested at the Department of Plant Pathology in 1975 and 1976 (Table 6).

The symptoms of secondary infection by PVY were visible in all potato cultivars. However, the symptoms were indistinct and depended on the interaction between a particular virus strain and a particular potato cultivar. It was therefore impossible to be certain whether a cultivar was susceptible or not. Severe necrosis, which often led to the death of the plant, commonly occurred in the cultivars Ostara and Hja's Timo (Figs. 27 and 28, page 234). Severe leaf necrosis ("leaf drop streak") was often found in the cultivars Norstern, Isabell and Carina (Fig. 30). Similar symptoms, although milder, were obvious in the cultivars Hja's Tuomas and Hja's Tanu. Dwarfing, mottling and leaf-curling were found in the following cultivars: Bintje, Jaakko, Pito, Puikelo, Record and Sanna. Milder symptoms occurred in the cultivars Frila, Posmo, Prevalent, Prumex, Sabina and Sieglinde. The symptoms in the cultivars Saturna and Veto always remained mild.

Greenhouse experiments showed that symptom severity depended more on the virus strain than the potato cultivar. All five isolates tested, which belonged to the $\mathrm{Y}^{\circ}$ strains, caused severe vein and leaf necrosis as primary and secondary symptoms in the cultivars Ostara and Record (Fig. 31). The isolates belonging to the $\mathrm{Y}^{\mathrm{n}}$ strains caused mottle, mosaic and rugosity but no necrosis was found (Fig. 29).

Natural transmission of PVY from outside of the experimental area to the field plots was rapid. Most potato cultivars became severely infected with naturally occurring PVY during the three year experimental period (Fig. 25). Significant differences in infection susceptibility were found between the cultivars. At the end of the third successive experimental year some cultivars were totally infected with virus $\mathrm{Y}$ when tubers from the previous crop were used as the seed material. In some cultivars the PVY \% of infected tubers was less than 10. In potato cultivars showing leaf or top necrosis the virus infection percentage was lower than the mean infection rate. 


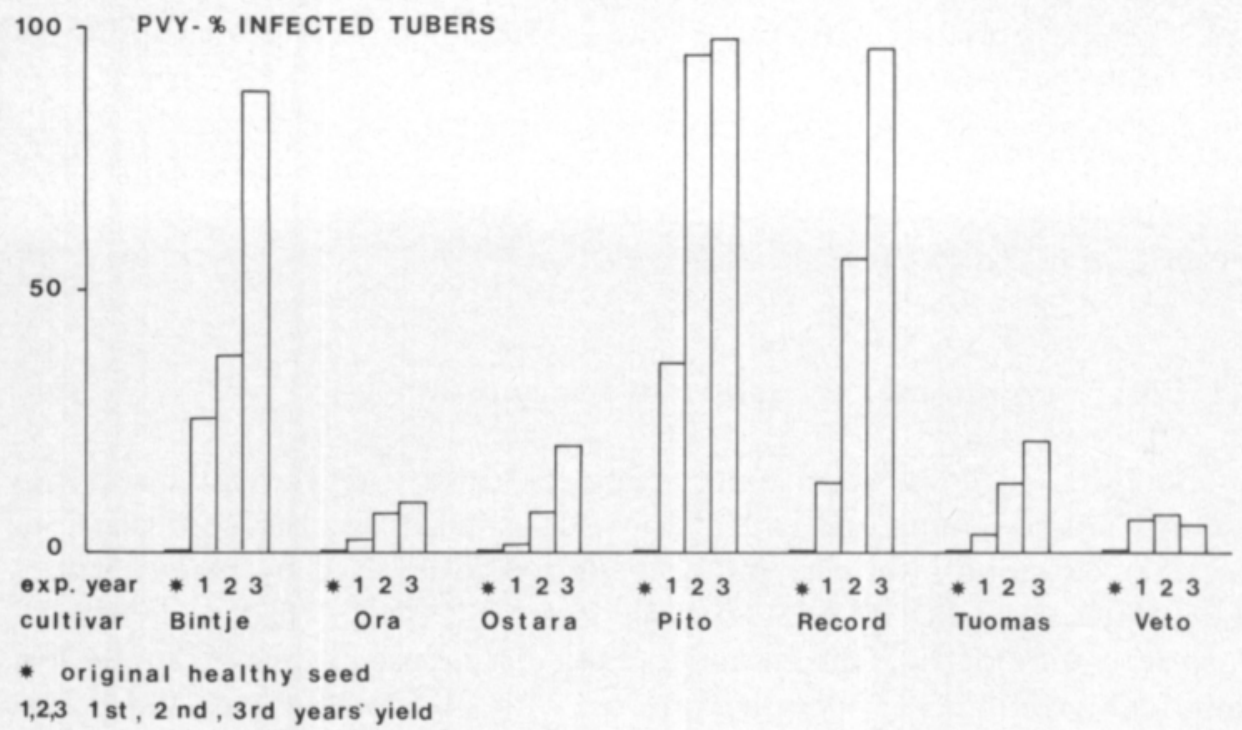

Fig. 25. Natural transmission of PVY in field experiments at Viikki during three successive growing seasons using seed material from the previous crop.

All of the PVY isolates studied were readily transmitted by the aphid species Myzus persicae, Aphis nasturtii-frangulae and Aulacorthum solani from potato plants to potatoes or other susceptible test plants when an acquisition time of $1-2$ mins and an inoculation time of 4-18 hours was used. All the attempts to transmit the virus with the aphid species Rhopalosiphum padi were unsuccessful.

\subsection{Symptoms in test plants and strain classification}

PVY isolates induced the following symptoms in the six test plant species which were used for virus isolation and classification:

A6 cut leaf:

- necrotic rings; the isolates YSF5, 10, 13, 15, 17, 19, 20, 21, 22, 24, 25, $27,29,30,31,32,36,39,40,41,42,44,48$

- necrotic rings and vein necrosis; the isolates YSF1, 3, 4, 5, 6, 7, 8, 9, $11,12,14,16,18,23,33,34,35,38$

- necrotic spots and vein necrosis; the isolates YSF1, 2, 3, 4, 6, 8, 9, 11, $12,14,18,22,26,27,28,33,37,45,46,47$

Solanum demissum A (SdA) (Fig. 34):

- systemic infection, latent or mild crinkling in the top leaves; the isolates YSF1, 2, 3, 4, 5, 6, 7, 8, 9, 11, 14, 16, 17, 18, 24, 25, 26, 28, 34, $35,41,45,46,47$

- systemic crinkling and chlorosis; the isolates YSF 10,12, 13, 15, 19, $20,21,22,23,27,29,30,31,32,33,36,37,38,39,40,42,43,44,48$

S. demissum Y (SdY) (Fig. 32):

- necrotic local lesions caused by all isolates 
- systemic leaf necrosis from all isolates

- top necrosis followed by premature death of the plants from all isolates excluding YSF1, 11, 17 and 35

Nicotiana glutinosa (Fig. 33):

- systemic vein-clearing and mild crinkling; the isolates YSF1, 3, 4, 6, 7, $8,9,14,17,18,26,28,30,31,34,35,39,40,41,44,45,46$

- severe systemic vein-clearing and crinkle; the isolates YSF2, 5, 10, 11, $12,13,15,16,19,20,21,22,23,24,25,27,29,32,33,36,37,38,42$, $43,47,48$

N. tabacum cv. Samsun (Figs. $35-38$ and 40 ):

- chlorotic or necrotic local rings followed by systemic vein-clearing; the isolates YSF4, 6, 26, 46

- systemic vein-clearing and vein mosaic; the isolates YSF1, 2, 3, 5, 7, 8, $9,11,12,14,16,18,24,28,45,47$

- systemic vein necrosis followed by leaf-drop; the isolates YSF10, 13, $15,17,19,20,21,22,23,25,27,29,30,31,32,33,34,35,36,37,38$, $39,40,41,42,43,44,48$

Physalis floridana (Fig. 39):

- some necrotic local lesions induced by all isolates

- systemic crinkling and chlorosis; the isolates YSF15, 17, 19, 20, 23, 25, $30,31,32,34,35,36,37,38,39,40,41,42,44,48$

- systemic chlorosis and stunting; the isolates YSF10, 13, 16, 21, 22, 29, 33,43

- systemic chlorosis, stunting and leaf necrosis; the isolates YSF1, 2, 5, $8,12,18,24,27,28,45,47$

- systemic leaf and top necrosis followed by premature death of the plants; the isolates YSF3, 4, 6, 7, 9, 11, 14, 26, 28, 46

The PVY isolates were classified according to the following symptoms in the test plants:

S. demissum Y: necrotic local lesions in 3-5 days followed by systemic leaf or top necrosis

A6 cut leaves: necrotic rings or lesions, often also veinal necrosis in $4-6$ days

The isolates were classified into strains according to their symptomology in N. tabacum cv. Samsun. The isolates inducing vein necrosis were classified into the $\mathrm{PVY}^{\mathrm{n}}$ strain and the rest into $\mathrm{PVY}^{\circ}$ strain. The following test plant symptoms also gave further information about the isolates:

- in A6: necrotic rings were caused by $86 \%$ of the $\mathrm{Y}^{\mathrm{n}}$ isolates and necrotic lesions by $80 \%$ of the $\mathrm{Y}^{\circ}$ isolates

- in S. demissum A: mild symptoms without chlorosis were caused by $95 \%$ of the $\mathrm{PVY}^{\circ}$ isolates and crinkling with chlorosis by $82 \%$ of $\mathrm{Y}^{\mathrm{n}}$ isolates

- in P. floridana: systemic necrosis was caused by all of the PVY ${ }^{\circ}$ isolates and chlorosis and stunting without necrosis by $97 \%$ of the $\mathrm{PVY}^{\mathrm{n}}$ isolates. 
Of 48 PVY isolates, 28 were classified into the strain $\mathrm{Y}^{\mathrm{n}}$ and 20 into into the strain $\mathrm{Y}^{\circ}$. The strain $\mathrm{Y}^{\mathrm{n}}$ of PVY was found more commonly than the strain $\mathrm{Y}^{\circ}$ in seed potatoes produced in Finland in 1981. Of 36 randomly selected tuber lots 28 were infected with $\mathrm{Y}^{\mathrm{n}}$ isolates and 8 with $\mathrm{Y}^{\circ}$ isolates. Both isolates were found in seed lots from southern Finland but only $\mathrm{Y}^{\mathrm{n}}$ isolates were found in tuber lots from northwestern Finland, which is where high class seed potato is mainly produced in this country. When early isolations of PVY were made from field potatoes the severe symptoms induced by the $\mathrm{Y}^{\circ}$ isolates may have led to more samples being taken of plants infected with this isolate rather than from plants showing the mild symptoms of other the isolates.

The origin of the isolates was as follows:

Isolates of the $\mathrm{PVY}^{\circ}$ strain:

YSF1, Pito, Seed Testing Institute 1975

YSF2, Pito, The University Farm, Viikki

YSF3, Pito -"-

YSF4, Ostara, Dutch imported seed 1976

YSF5, Record, Hankkija Plant Breeding Institute 1976

YSF6, Isabell, Dutch imported seed 1976

YSF7, Puikelo, Espoo

YSF8, Prevalent, Prestoperuna Ltd

YSF9, Hja's Timo, Hankkija Plant Breeding Institute 1980

YSF11, Pito, Espoo

YSF12, Record, Viikki

YSF14, Puikelo, Inari

YSF16, Record, Raisio

YSF18, Ostara, Porvoo

YSF24, Sabina, Kitee

YSF26, Prevalent, Alajärvi

YSF28, Eigenheimer, Porvoo

YSF45, Bintje, Ahvenanmaa

YSF46, "Black local", Viikki

YSF47, Record, Lammi

Isolates of the $\mathrm{PVY}^{\mathrm{n}}$ strain:

YSF10, Bintje, The University Farm, Viikki 1979

YSF13, Pito, Ahvenanmaa 1979

YSF15, Record, Tyrnävä

YSF17, Record, Liminka

YSF19, Record, Liminka

YSF20, Sanna, Tyrnävä

YSF21, Pito, Tyrnävä

YSF22, Sanna, Liminka

YSF23, Record, Tyrnävä

YSF25, Record, Liminka

YSF27, Record, Kitee 
Table 16. The symptoms induced by PVY ${ }^{\circ}$ isolates (YSF4 and YSF11) and PVY isolates (YSF10 and YSF15) in various test plants. If any differences within a strain were found they are mentioned in the table. "L" indicates local symptoms and "S" systemic symptoms.

\begin{tabular}{|c|c|c|}
\hline Test plant & $\mathrm{PVY}^{\circ}$ isolates & $\mathrm{PVY}^{\mathrm{n}}$ isolates \\
\hline A6 & Necr. $\mathrm{L}$ lesions or rings in $4-6 \mathrm{~d}$. & $\begin{array}{l}\text { Necr. } L \text { rings and vein necrosis in } \\
4-6 \mathrm{~d} \text {. }\end{array}$ \\
\hline C. amaranticolor & $\begin{array}{l}\text { Chlor. and necr. } \mathrm{L} \text { lesions in } 10-12 \\
\text { d. }\end{array}$ & Chlor. $\mathrm{L}$ lesions in $10-12 \mathrm{~d}$. \\
\hline C. quinoa & $\begin{array}{l}\text { Few diffusive chlor. } \mathrm{L} \text { lesions in } \\
10-12 \mathrm{~d} \text {. }\end{array}$ & Few chlor. $\mathrm{L}$ lesions in $10-12 \mathrm{~d}$. \\
\hline G. globosa & Not infected & Not infected \\
\hline L. chilense & $\begin{array}{l}\text { S vein-clearing (YSF11); S mottle } \\
\text { and mosaic (YSF4) in 12-16 d. }\end{array}$ & $\begin{array}{l}\text { S vein-clearing and vein mosaic in } \\
12-16 \mathrm{~d} \text {. }\end{array}$ \\
\hline L. esculentum & Latent $\mathrm{S}$ infection & Latent $\mathrm{S}$ infection \\
\hline L. pimpinellifolium & Latent $\mathrm{S}$ infection & $\begin{array}{l}S \text { vein-clearing and mosaic in } \\
14-16 \mathrm{~d} \text {. (fig. } 41 \text { ) }\end{array}$ \\
\hline N. physaloides & Latent $\mathrm{S}$ infection & Latent $S$ infection \\
\hline N. clevelandii & $\begin{array}{l}\text { S chlorosis followed by necrosis } \\
\text { and premature death in } 20-28 \mathrm{~d} \text {. }\end{array}$ & $\begin{array}{l}\text { S vein-clearing and mosaic followed } \\
\text { by necrosis and premature death in } \\
20-28 \mathrm{~d} \text {. }\end{array}$ \\
\hline N. debneyi & $\begin{array}{l}\text { S interveinal chlorosis (YSF11); } \\
\text { chlor. spots (YSF4) in 6-10 d. }\end{array}$ & $\begin{array}{l}S \text { interveinal chlorosis and yellow } \\
\text { mosaic in } 6-8 \mathrm{~d} \text {. }\end{array}$ \\
\hline N. glutinosa & $\begin{array}{l}\text { S vein-clearing and crinkling in } \\
6-10 \mathrm{~d} \text {. }\end{array}$ & $\begin{array}{l}\text { S vein-clearing and severe crinkling } \\
\text { in } 6-10 \mathrm{~d} \text {. }\end{array}$ \\
\hline N. tabacum cv. Samsun & $\begin{array}{l}\text { Chlor. and necr. } \mathrm{L} \text { rings in } 5-8 \mathrm{~d} \text {. } \\
\text { (YSF } 4), \mathrm{S} \text { vein-clearing and inter- } \\
\text { veinal mosaic in } 7-10 \mathrm{~d} \text {. }\end{array}$ & $\begin{array}{l}\mathrm{S} \text { vein necrosis in } 10-14 \mathrm{~d} \text {. fol- } \\
\text { lowed by leaf-drop }\end{array}$ \\
\hline P. floridana & $\begin{array}{l}\text { Necr. } \mathrm{L} \text { lesions in } 4-6 \mathrm{~d} \text {. followed } \\
\text { by leaf and top necrosis in } 8-15 \mathrm{~d} \text {. } \\
\text { and premature death in } 20-30 \mathrm{~d} \text {. }\end{array}$ & $\begin{array}{l}\text { Chlor. and necr. } \mathrm{L} \text { lesions in } 4-6 \mathrm{~d} \text {. } \\
\text { followed by } \mathrm{S} \text { chlorosis and stunt- } \\
\text { ing in } 10-15 \mathrm{~d} \text {. }\end{array}$ \\
\hline S. chacoense & $\begin{array}{l}\text { Necr. } \mathrm{L} \text { lesions in } 4-6 \mathrm{~d} \text {. followed } \\
\text { by vein and top necrosis in } 10-15 \\
\text { d. and premature death in } 20-35 \mathrm{~d} \text {. }\end{array}$ & $\begin{array}{l}\text { Necr. L lesions in } 4-6 \mathrm{~d} \text {. followed } \\
\text { by vein necrosis (YSF10) or top } \\
\text { necrosis (YSF15) in } 12-16 \mathrm{~d} \text {. }\end{array}$ \\
\hline S. demissum A & $\begin{array}{l}\text { S latent infection (YSF4) or mild } \\
\text { crinkling in } 10-14 \mathrm{~d} \text {. }\end{array}$ & $\mathrm{S}$ chlorosis and crinkling in $8-12 \mathrm{~d}$. \\
\hline S. demissum Y & $\begin{array}{l}\text { Necr. L lesions in } 3-6 \mathrm{~d} \text {. followed } \\
\text { by vein and top necrosis; premature } \\
\text { death by YSF4 }\end{array}$ & $\begin{array}{l}\text { Necr. } \mathrm{L} \text { lesions in } 3-6 \mathrm{~d} \text {. followed } \\
\text { by vein and top necrosis and pre- } \\
\text { mature death in } 20-35 \mathrm{~d} \text {. }\end{array}$ \\
\hline
\end{tabular}

YSF29, Record, Tyrnävä

YSF31， Record, Hämeenlinna 1981

YSF32, Sabina, Lumijoki 1981

YSF33, Bintje, Porvoo 1981 
YSF34, Provita, Ahvenanmaa

YSF35, Bintje, Ahvenanmaa

YSF36, Record, Porvoo

YSF37, Bintje, Porvoo

YSF38, Bintje, Porvoo

YSF39, Record, Tyrnävä

YSF40, Bintje, Porvoo

YSF41, Record, Tyrnävä

YSF42, Record, Tyrnävä

YSF43, Pito, Tyrnävä

YSF44, Record, Porvoo

YSF48, Record, Lammi

When the symptoms of the 4 selected type isolates of PVY were studied further (with the use of wider host ranges) some further information about the differences between the isolates were obtained, but no new features important in strain classification were found (Table 16).

\subsection{Sap properties}

The thermal inactivation point (TIP) values obtained for the PVY isolates were between 48 and 57 C. The TIP value of the isolate YSF15 was remarkably higher than that of the other isolates. The virus greatly lost its infectivity near the inactivation temperature (Table 17).

All of the test plants that showed local symptoms also became systemically infected.

The dilution end point (DIP) values were between $10^{-2}$ and $10^{-3}$ and were higher for the $\mathrm{Y}^{\mathrm{n}}$ strain isolates than they were for the $\mathrm{Y}^{\circ}$ isolates. The infectivity was markedly reduced near the dilution end point (Table 18).

All of the test plants that showed local symptoms also became systemically infected.

Table 17. The thermal inactivation point (TIP) values for 4 PVY isolates determined with Nicotiana glutinosa sap inoculated into Solanum demissum Y.

\begin{tabular}{|c|c|c|c|c|}
\hline \multirow[b]{3}{*}{ Temperature $\mathrm{C}$} & \multicolumn{4}{|c|}{$\begin{array}{l}\text { The mean number of lesions/leaf } \\
\text { PVY strain and isolate }\end{array}$} \\
\hline & \multicolumn{2}{|c|}{$\mathrm{PVY}^{\circ}$} & \multicolumn{2}{|c|}{ PVY $^{n}$} \\
\hline & YSF4 & YSF11 & YSF10 & YSF15 \\
\hline room temperature & 21.0 & 24.7 & 21.3 & 34.0 \\
\hline 45 & 6.0 & 16.3 & 9.7 & 71.7 \\
\hline 48 & 2.3 & 4.0 & 2.0 & 23.0 \\
\hline 51 & 1.0 & 1.3 & 0.3 & 14.7 \\
\hline 54 & 0.0 & 0.0 & 0.0 & 4.0 \\
\hline 57 & 0.0 & 0.0 & 0.0 & 0.3 \\
\hline 60 & 0.0 & 0.0 & 0.0 & 0.0 \\
\hline 63 & 0.0 & 0.0 & 0.0 & 0.0 \\
\hline
\end{tabular}


Table 18. The dilution end (DIP) point values of $4 \mathrm{PVY}$ isolates determined by inoculating Nicotiana glutinosa sap into Solanum demissum Y.

\begin{tabular}{|c|c|c|c|c|}
\hline \multirow[b]{3}{*}{ Dilution } & \multicolumn{4}{|c|}{$\begin{array}{l}\text { The mean number of lesions/leaf } \\
\text { PVY strain and isolate }\end{array}$} \\
\hline & \multicolumn{2}{|c|}{$\mathrm{PVY}^{\circ}$} & \multicolumn{2}{|c|}{$\mathrm{PVY}^{n}$} \\
\hline & YSF4 & YSF11 & YSF10 & YSF15 \\
\hline undiluted & 24.7 & 33.3 & 27.7 & 39.0 \\
\hline $10^{-1}$ & 11.3 & 19.7 & 38.7 & 62.0 \\
\hline $10^{-2}$ & 1.0 & 2.3 & 4.7 & 21.3 \\
\hline $10^{-3}$ & 0.0 & 0.0 & 0.7 & 4.0 \\
\hline $10^{-4}$ & 0.0 & 0.0 & 0.0 & 0.0 \\
\hline $10^{-5}$ & 0.0 & 0.0 & 0.0 & 0.0 \\
\hline
\end{tabular}

In negatively stained EM preparates made from potato or test plant sap the virus particles had a typical length of c. $730 \mathrm{~nm}$. The particle density was higher in the $\mathrm{PVY}^{\mathrm{n}}$ preparates than in the $\mathrm{PVY}^{\circ}$ preparates. In EM micrographs PVY particles appeared more flexous than those of PVS or PVM and were significantly longer than PVX particles and could easily be separated from them if several particles were compared. The only difference between PVY and PVA was the higher particle density of PVY, however this character cannot be used to reliably separate these two viruses.

\subsection{Virus purification}

The purification method of STACE-SMITH \& TREMAINE (1970) was initially used as the standard purification method but it gave relatively low yields of purified virus. The highest yields obtained with this method were from the isolates YSF1 and YSF4 (in N. glutinosa) and they were $7 \mathrm{mg}$ and 4 $\mathrm{mg} / \mathrm{kg}$ respectively.

Later, a method based on chloroform + buthanol clarification and differential centrifugations was used and it gave the following yields of purified virus: YSF4 $9 \mathrm{mg}$, YSF11 $12 \mathrm{mg}$, YSF10 $21 \mathrm{mg}$ and YSF15 $27 \mathrm{mg} / \mathrm{kg}$ leaves. This purification method had some destructive effects on the coat protein of the virus particles and it interfered with virus movement during density gradient centrifugation as well as reducing the stability of the virus. Also relatively high amounts of low molecular weight plant proteins existed in the virus preparates when they were ready for density gradient centrifugation.

The third purification method used, which was a slight modification of the method described by LEISER \& RICHTER (1978), was found to be the most suitable for PVY. The virus containing preparates were almost clean even before density gradient centrifugation (Fig. 62, page 251) and the virus particles retained their typical properties at the end of the purification procedure. In density gradient centrifugation the virus moved to form a narrow band and very little particle aggregation was observed (Fig. 26). After one cycle of density gradient centrifugation the virus preparates were clean and the value 


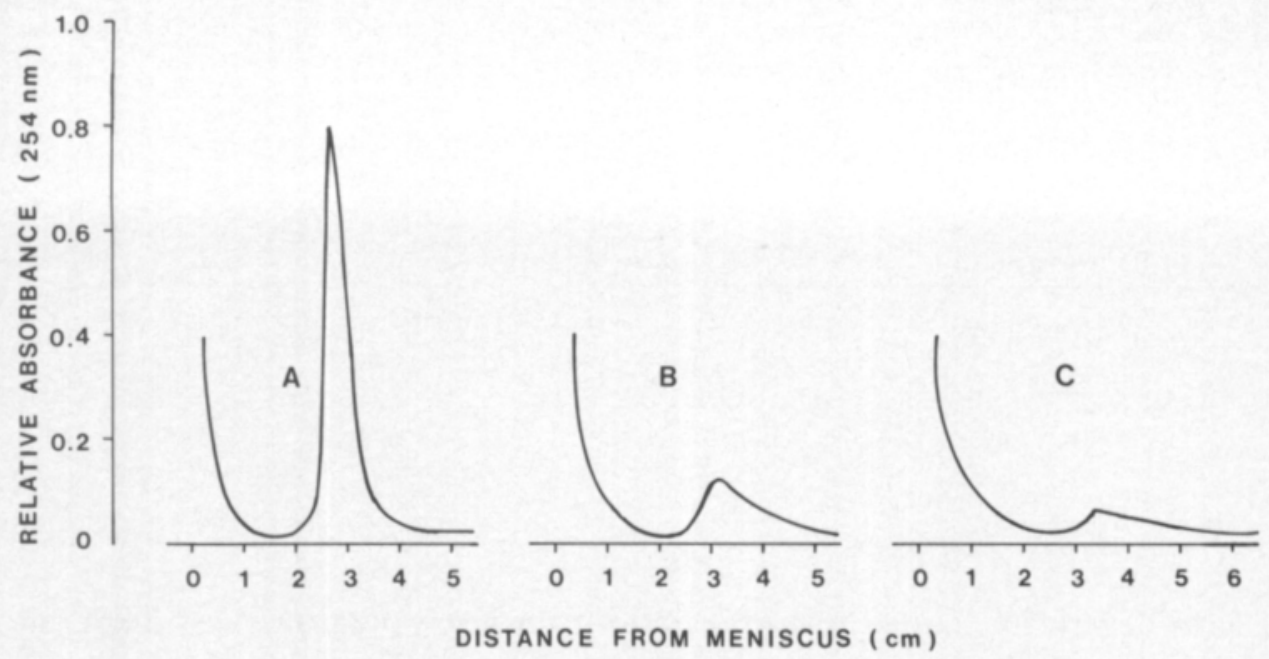

Fig. 26. Scanning pattern obtained in the ISCO density-gradient fractionator after one cycle of densitygradient centrifugation for $160 \mathrm{~min}$ at $24000 \mathrm{rpm}$ (Beckman SW-27 rotor) in $5-35 \%$ w/v linear sucrose gradients.

$a=$ normal virus movement as indicated by a narrow single band

$\mathrm{b}=$ broad band due to particle aggregation problems

$\mathrm{c}=$ band showing both particle aggregation and distortion

for the absorbance relation A 254/A 280 was 1.21 . The maximum yields obtained of purified virus isolates YSF11 ( $N$. glutinosa) and YSF15 $(N$. tabacum cv. Samsun) were $16 \mathrm{mg}$ and $26 \mathrm{mg} / \mathrm{kg}$ leaf matter respectively. The virus preparates could be preserved for at least 6 months in $0.005 \mathrm{M}$ borate buffer containing $0.03 \mathrm{M} \mathrm{NaCl}$ and $0.003 \mathrm{M} \mathrm{Na}$-citrate at $\mathrm{pH} 8.0$.

\subsection{Serological properties}

\subsubsection{Homologous titers of the antisera}

The four PVY isolates were moderate to good immunogens when injected intramusculary with Freund's adjuvant into rabbits. The immune response of $\mathrm{PVY}^{\mathrm{n}}$ isolates was better than that of $\mathrm{PVY}^{\circ}$ isolates. A titer high enough for use in the serological tests was attained within 3 to 6 weeks after the first injection (Table 19). The non-spesific titers of the antisera as determined with the microprecipitin and the chloroplast agglutination test were 1/4-1/16.

\subsubsection{Heterologous titers of the antisera}

Serological variation between the PVY isolates was found and the heterologous titers were $2-8$ times lower than the homologous ones. The titers of foreign antisera against Finnish PVY isolates were low. The foreign antisera were more closely related to $\mathrm{Y}^{\circ}$ isolates than to $\mathrm{Y}^{\mathrm{n}}$ isolates (Table 20).

Comparable information about the serological relationships between the PVY isolates was also obtained from EM-serological AVM tests. Good 
agreement with the results from the microprecipitin tests was found but the titers determined for the antisera were somewhat higher (Table 21).

Table 19. The injection schedule and the homologous titers of PVY antisera as determined with the microprecipitin test. $\rightarrow=$ injection

\begin{tabular}{|c|c|c|c|c|}
\hline \multirow{2}{*}{$\begin{array}{l}\text { Time } \\
\text { in weeks }\end{array}$} & \multicolumn{4}{|c|}{ Virus isolates and their homologous titers } \\
\hline & YSF1 & YSF4 & YSF10 & YSF11 \\
\hline 0 & $\rightarrow$ & $\rightarrow$ & $\rightarrow$ & $\rightarrow$ \\
\hline 1 & $\rightarrow$ & $\rightarrow$ & $\rightarrow$ & $\rightarrow$ \\
\hline 2 & $\rightarrow$ & $\rightarrow$ & $\rightarrow$ & $\rightarrow$ \\
\hline 3 & $\rightarrow 1 / 128$ & $\rightarrow 1 / 256$ & & \\
\hline 4 & & & $1 / 256$ & $1 / 256$ \\
\hline 5 & $1 / 256$ & $1 / 256$ & & \\
\hline 6 & & & $\rightarrow 1 / 512$ & $\rightarrow 1 / 256$ \\
\hline 7 & $\rightarrow 1 / 256$ & $\rightarrow 1 / 256$ & & \\
\hline 8 & & & $1 / 1024$ & $1 / 1024$ \\
\hline 9 & $1 / 512$ & $1 / 512$ & & \\
\hline 10 & the rabbit died & & $1 / 2048$ & $1 / 512$ \\
\hline 11 & & $1 / 512$ & & \\
\hline 12 & & & $\rightarrow 1 / 1024$ & $\rightarrow 1 / 512$ \\
\hline 13 & & $\rightarrow 1 / 256$ & & \\
\hline 14 & & & $1 / 2048$ & $1 / 1024$ \\
\hline 15 & & & & \\
\hline 16 & & $1 / 512$ & $1 / 2048$ & $1 / 512$ \\
\hline 17 & & & & \\
\hline 18 & & $1 / 1024$ & $1 / 512$ & \\
\hline 19 & & & & \\
\hline 20 & & $1 / 256$ & & \\
\hline 21 & & & & \\
\hline 22 & & $1 / 256$ & & \\
\hline
\end{tabular}

Table 20. The heterologous titers of PVY antisera against 3 Finnish PVY isolates as determined with the microprecipitin test.

\begin{tabular}{llllllll}
\hline \multirow{2}{*}{ Antigen } & \multicolumn{7}{c}{ Virus isolates and their heterologous titers } \\
& YSF1 & YSF4 & YSF10 & YSF11 & Estonian & Polish & Hungarian \\
\hline & & & & & & & \\
YSF4 & $1 / 256$ & $1 / 512$ & $1 / 256$ & $1 / 512$ & $1 / 128$ & $1 / 32$ & $1 / 32$ \\
YSF10 & $1 / 128$ & $1 / 64$ & $1 / 2048$ & $1 / 128$ & $1 / 32$ & $1 / 16$ & $1 / 16$ \\
YSF11 & $1 / 512$ & $1 / 256$ & $1 / 512$ & $1 / 1024$ & $1 / 256$ & $1 / 32$ & $1 / 64$ \\
\hline
\end{tabular}

* The isolate YSF1 was lost in the course of the study.

Table 21. The homologous and heterologous titers of four PVY antisera as determined with an EMserological test.

\begin{tabular}{lllll}
\hline Antigen & YSF1 & \multicolumn{2}{c}{ Antisera and their titers } \\
& YSF4 & YSF10 & YSF11 \\
\hline YSF4 & $1 / 512$ & $1 / 1024$ & $1 / 512$ & $1 / 2048$ \\
YSF10 & $1 / 256$ & $1 / 256$ & $1 / 4096$ & $1 / 512$ \\
\hline
\end{tabular}



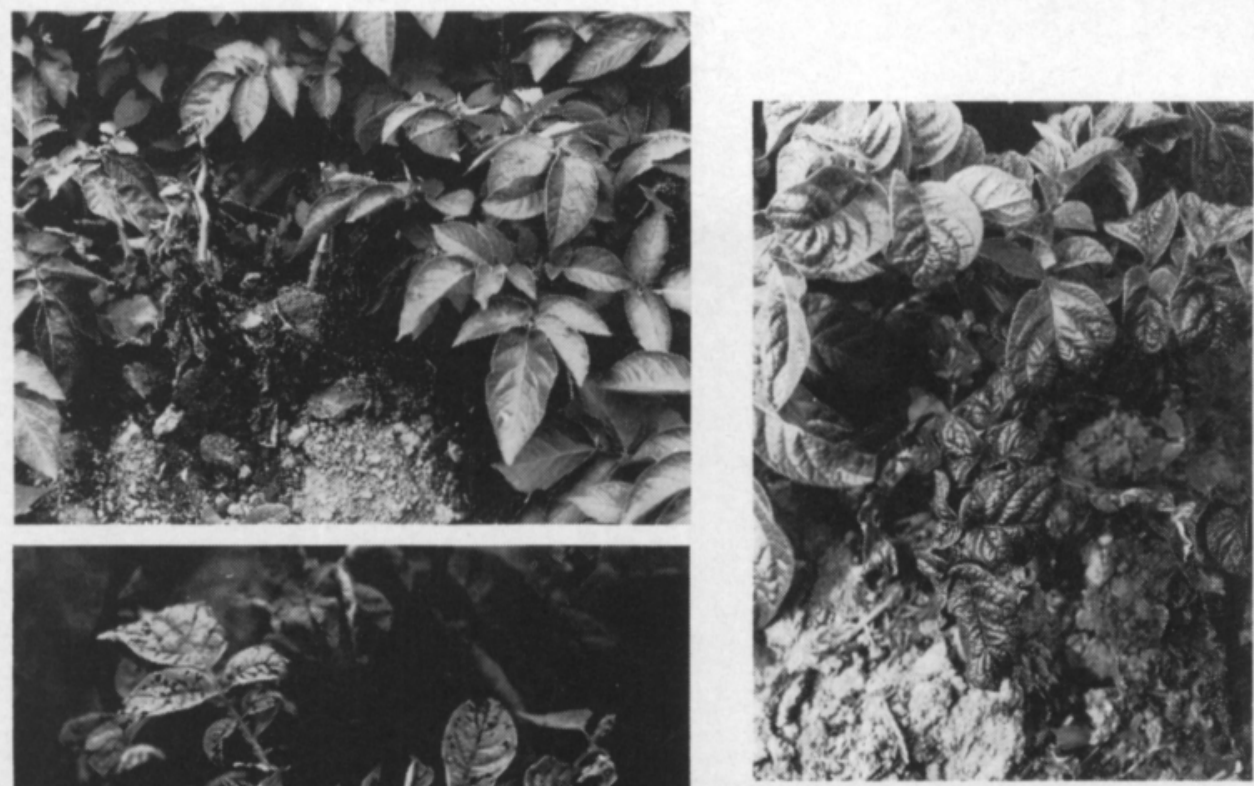

Fig. 30

Fig. 28
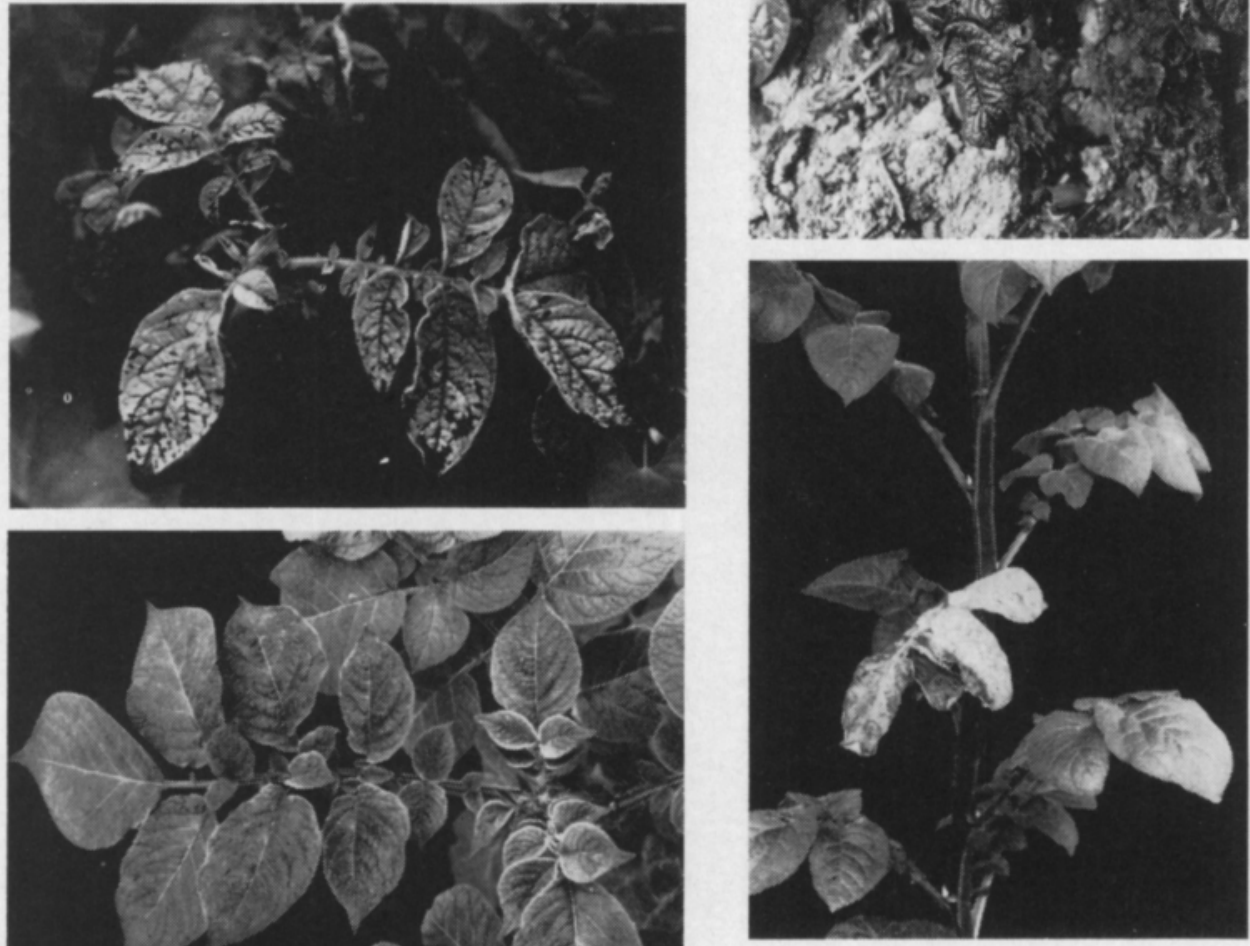

Fig. 31

Fig. 29

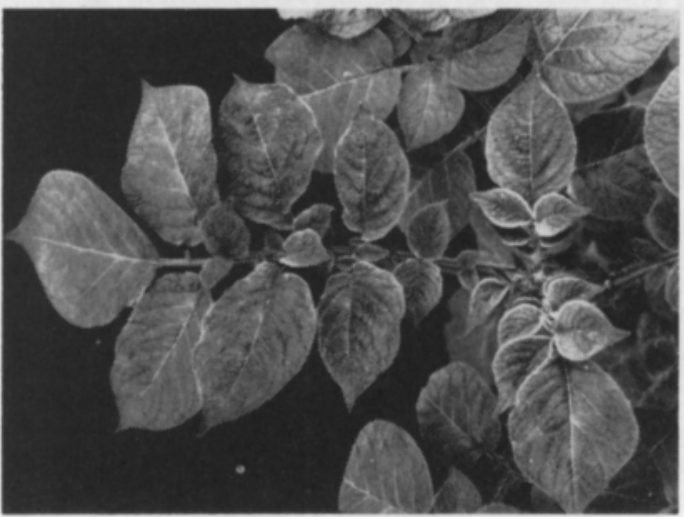

Fig. 27. Secondarily infected potato plant cv. Ostara killed by $\mathrm{PVY}^{\circ}$.

Fig. 28. Severe vein and top necrosis in potato cv. Hja's Timo secondarily infected by PVY ${ }^{\circ}$. The disease leads to the death of the plant.

Fig. 29. Primary symptoms, mosaic and faint chlorotic spots in potato cv. Record infected with PVY isolate YSF10.

Fig. 30. Rugosity, stunting and leaf drop symptoms in potato cv. Isabell infected with $\mathrm{PVY} \mathrm{Y}^{\circ}$ isolate YSF6.

Fig. 31. Local and systemic necrosis in potato cv. Record 4 weeks after mechanical inoculation with PVY isolate YSF11. 

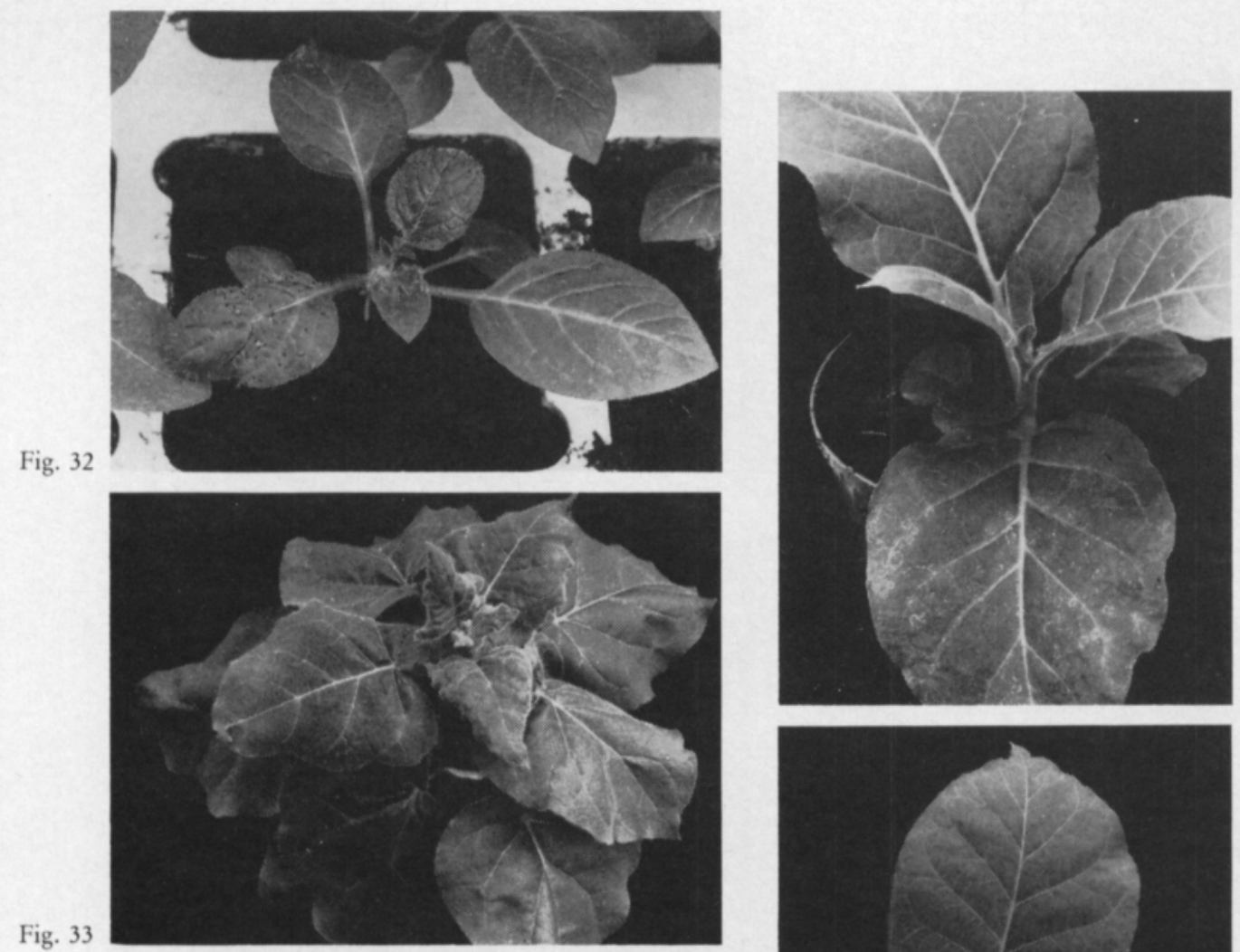

Fig. 35

Fig. 33

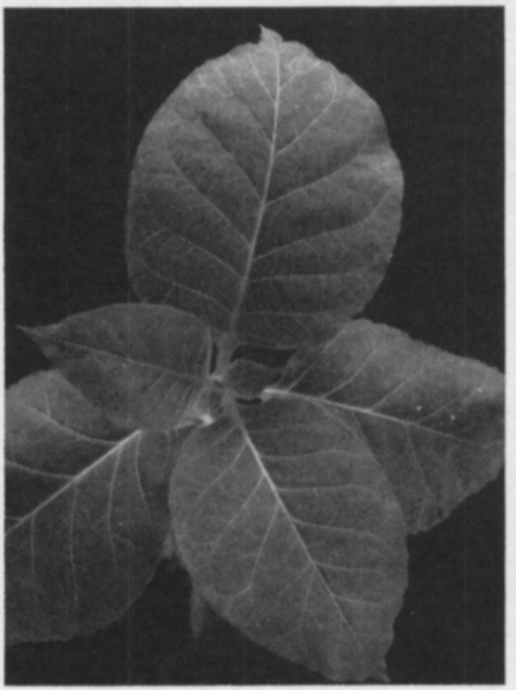

Fig. 36

Fig. 34

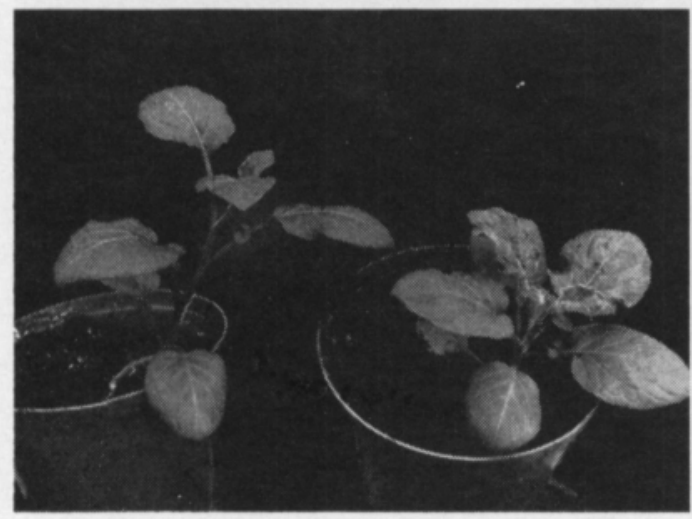

Fig. 32. Systemic necrosis in Solanum demissum Y 10 days after aphid transmission with PVY ${ }^{\mathrm{n}}$.

Fig. 33. Systemic vein clearing, wrinkling and stunting in Nicotiana glutinosa infected with PVYn isolate YSF15.

Fig. 34. Solanum demissum A plants infected with PVYo isolate YSF4 (left) and PVYn isolate YSF29 (right). The latter shows systemic chlorosis and rugosity.

Fig. 35. Nicotiana tabacum cv. Samsun infected with PVY॰ isolate YSF4 showing local chlorotic and necrotic rings and systemic vein clearing.

Fig. 36. Nicotiana tabacum cv. Samsun infected with PVY ${ }^{\circ}$ isolate YSF11 showing faint chlorotic local spots, and severe systemic vein clearing and vein mosaic. 


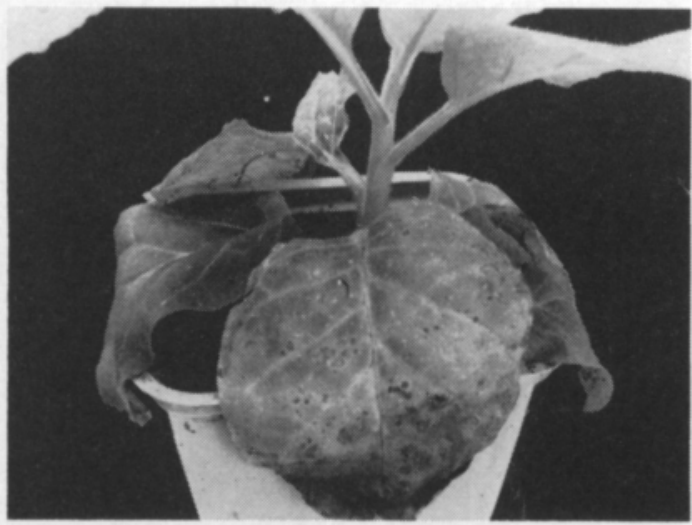

Fig. 37

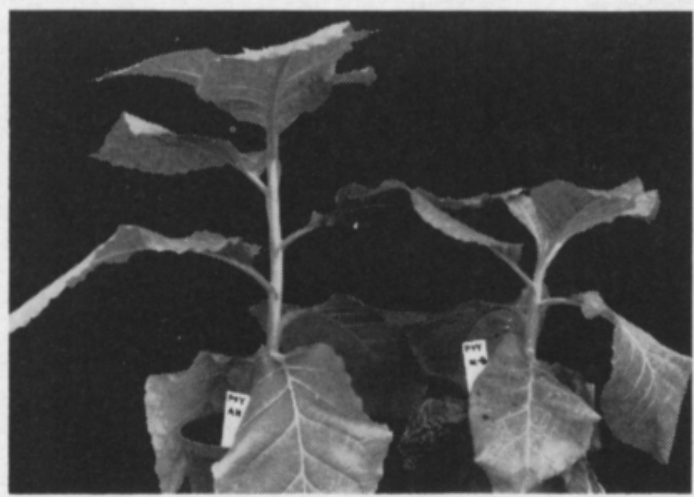

Fig. 38

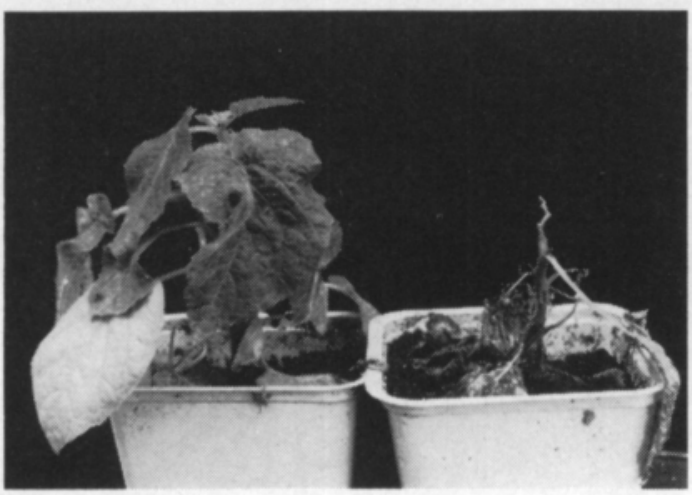

Fig. 39

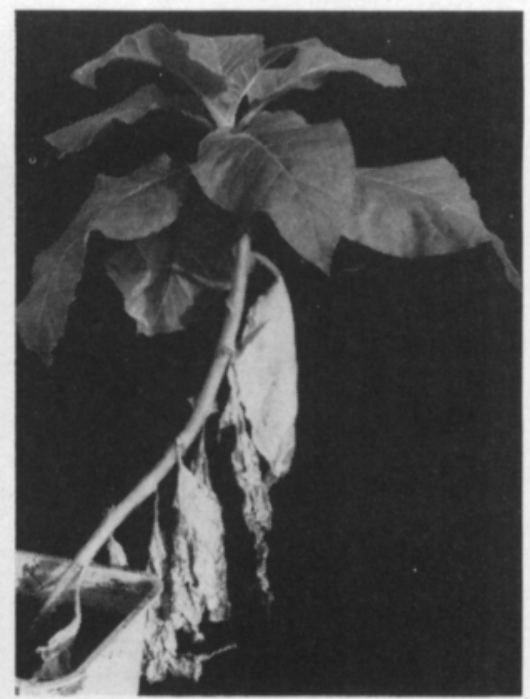

Fig. 40

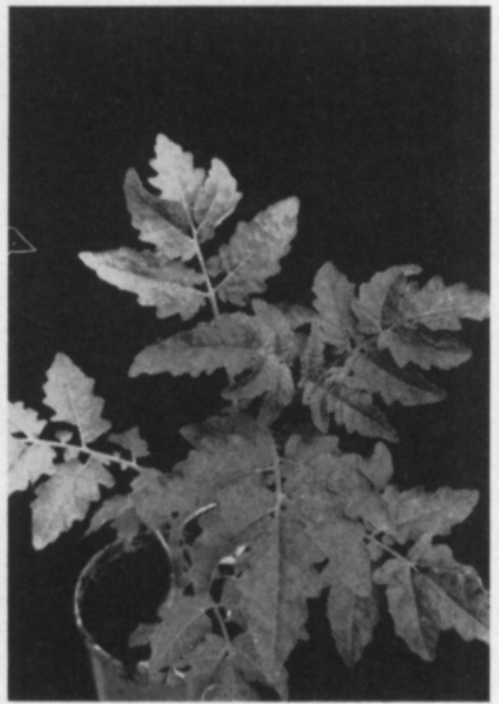

Fig. 41

Figs. 37 and 40. Nicotiana tabacum cv. Samsun infected with any PVY ${ }^{n}$ strain isolate first show systemic vein necrosis (Fig. 37) and then later leaf drop (Fig. 40).

Fig. 38. Nicotiana tabacum cv. Samsun plants infected with PVY isolate YSF12 (left) and PVY ${ }^{\mathrm{n}}$ isolate YSF10 (right). The latter shows severe vein necrosis, the former mild vein clearing.

Fig. 39. Physalis floridana plants infected with PVYn isolate YSF13 (left) and PVYo isolate YSF18 (right). The former shows chlorosis, wrinkling and stunting, the latter has been killed by the virus.

Fig. 41. Severe systemic mosaic and chlorotic symptoms in Lycopersicon pimpinellifolium infected with $\mathrm{PVY}^{\mathrm{n}}$ isolate YSF15. 


\section{Potato virus A (PVA)}

Potato virus A, */*:*/ E/E:S/Ap, first described by MURPHY \& McKAY (1932) can be found all over the world wherever potatoes are grown. Selected synonyms for the virus are Marmor solani, Potato mild mosaic, Potato virus $\mathrm{P}$ and Solanum virus 3 (BARTELS 1971). The virus has long flexous particles of c. $730 \times 11 \mathrm{~nm}$. It is transmitted by several aphid species in a non persistent manner and can also be spread mechanically. The mechanical means of transmission, however, has no importance because the virus is rather unstable (Mac LAGHLAN et al. 1953, BARTELS 1971, O’BRIEN \& RICH 1976).

The narrow host range of this virus is restricted to the Solanaceae. The most suitable local lesion hosts are A6-hybrid (Solanum demissum $\times S$. tuberosum cv. Aquila) and $S$. demissum A. Systemic symptoms are seen in Nicotiana tabacum cvs. Samsun and White Burley, Nicandra physaloides and Lycopersicon pimpinellifolium (Mac LAGHLAN et al. 1953, BARTELS 1970, 1971, de BOKX 1970a, 1975).

In potatoes the virus causes mild mosaic, chlorosis, mottling and mild crinkling. In some potato cultivars the virus is latent but on other hand it may cause top necrosis in hypersensitive cultivars (Mac LAGHLAN 1953, BARTELS 1971, de BOKX 1975, O'BRIEN \& RICH 1976).

Tuber yield losses caused by potato virus A are normally relatively low, from 2 to $15 \%$ (de BOKX 1975), but they may be as high as $40 \%$ (BORCHARDT et al. 1964, BARTELS 1971). In cases of mixed infection with viruses $\mathrm{X}, \mathrm{S}, \mathrm{M}$ or $\mathrm{Y}, \mathrm{PVA}$ always causes significant tuber yield losses (BARTELS 1971).

\subsection{Properties of the virus isolates that occur in Finland}

\subsubsection{Occurrence and symptomology in potatoes and test plants}

Potato virus A was relatively rarely found in diseased potato tubers or plants. Four isolates were successfully recovered from the following sources:

ASF1, Pito, Viikki

ASF2, Eigenheimer, Porvoo

ASF3, Eigenheimer, Porvoo

ASF4, "Black local", Viikki
1975

1981

1982

1982

The virus isolate ASF1 induced mild mosaic in its natural host, whereas the isolates ASF2 and ASF3 induced chlorosis and crinkling and the isolate ASF4 caused chlorosis and severe crinkling (Figs. 42 and 44). toms:

In the selected test plants all virus isolates induced the following symp-

A6 cut leaf: Necrotic "starlike" local lesions in 4-5 days.

S. demissum A: Numerous necrotic local lesions in 3-5 days followed by systemic vein necrosis in 5-8 days and premature death of the plant in $10-15$ days (Fig. 43). 
S. demissum Y: Occasional necrotic local lesions in 4-5 days followed by latent systemic infection.

P. floridana: The plants did not become infected.

N. glutinosa: The plants did not become infected.

L. pimpinellifolium: Systemic necrosis in 8-12 days.

The symptoms differed in the following test plants:

$N$. physaloides: Systemic vein-clearing was caused by all isolates, however the isolate ASF4 also caused leaf necrosis (Fig. 45).

N. tabacum cv. Samsun: Systemic vein-clearing and diffuse mottling in 8-10 days. The isolate ASF4 caused more severe symptoms than the other isolates.

\subsubsection{Sap properties}

Electron micrographs of PVA particles look similar to those of PVY and no distinction between the particles of these two viruses can be seen. Very few PVA particles are seen in EM preparates made from either potato or $N$. physaloides leaf sap (Fig. 63, page 251).

The thermal inactivation point values determined for the isolates ASF2 and ASF4 were $45 \mathrm{C}$ and $48 \mathrm{C}$ and the dilution end point values were $10^{-1}$ and $10^{-2}$ respectively. At all these end point values $N$. physaloides and $S$. demissum A plants became systemically infected.

According to host range and sap properties the PVA isolates can be classified into the mild (ASF1-3) or the moderate strains (ASF4).

\subsubsection{Virus purification and serological identification}

In this study only a small amount of virus could be purified from systemically infected leaves of $N$. tabacum cv. Samsun. The method of LEISER \& RICHTER (1978) was used with slight modifications and the yield of purified virus was $1.1 \mathrm{mg} / 100 \mathrm{~g}$ leaves. Several methods for the purification of PVA have been developed but all of them have difficulties with virus aggregation and have resulted in low yields of pure virus. Specific antisera to the virus have been prepared, however, because the virus is a good immunogen (FRIBOURG \& ZOETEN 1970, MAAT \& MIERZWA 1975, GUGERLI 1979, SINGH \& McDONALD 1981).

Attempts at serological identification of the virus in plant samples were inconclusive until the ELISA method was employed (MAAT \& de BOKX 1978, GUGERLI 1979). For routine identification of PVA the A6 cut leaf test had previously been widely used (KÖHLER 1953, de BOKX 1970a).

The four PVA isolates tested could reliably be identified with the ELISA test in secondarily infected dormant tubers, sprouted tubers and leaves. The virus isolates did not give any significant reaction when tested with different PVY antiserum reagents in the ELISA test.

High percentages of PVA infected tubers have been found in tuber samples from the Experimental Station of Central Finland in tests done 
during the winter of 1983 . Up to this point it is still unclear as to whether this virus is abnormally common in the vicinity of this station or not.

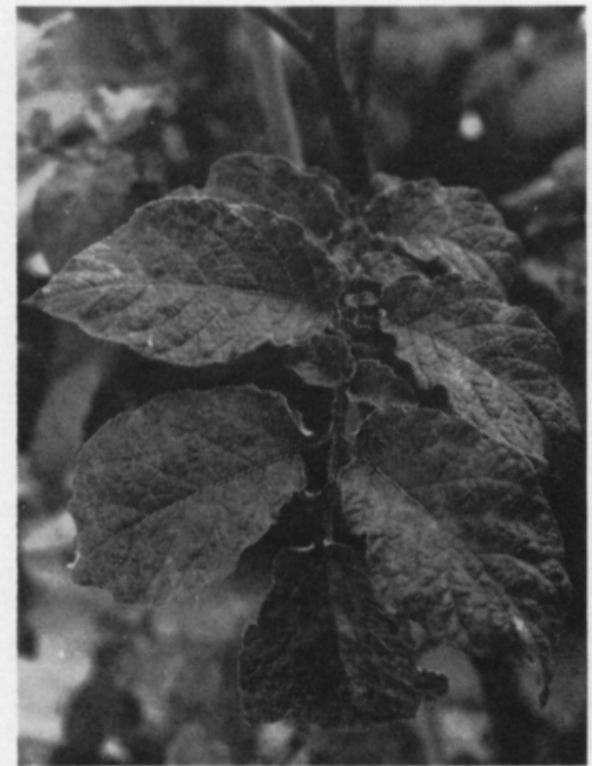

Fig. 42

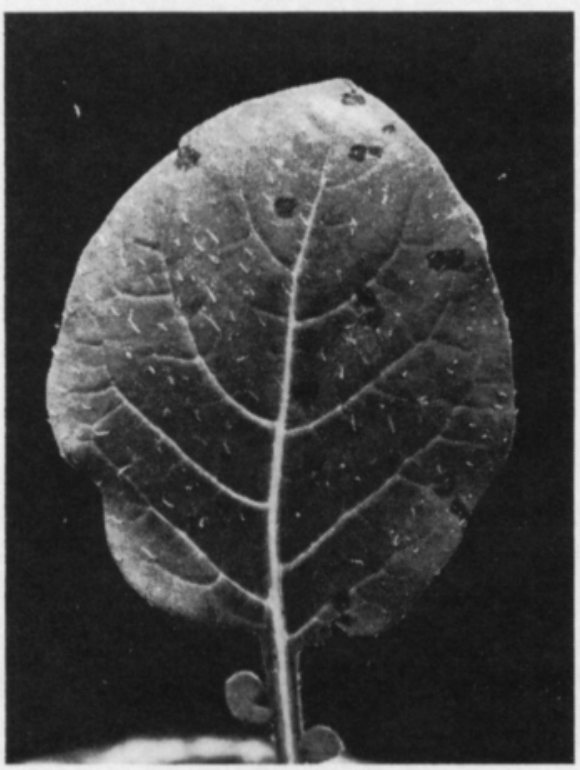

Fig. 43

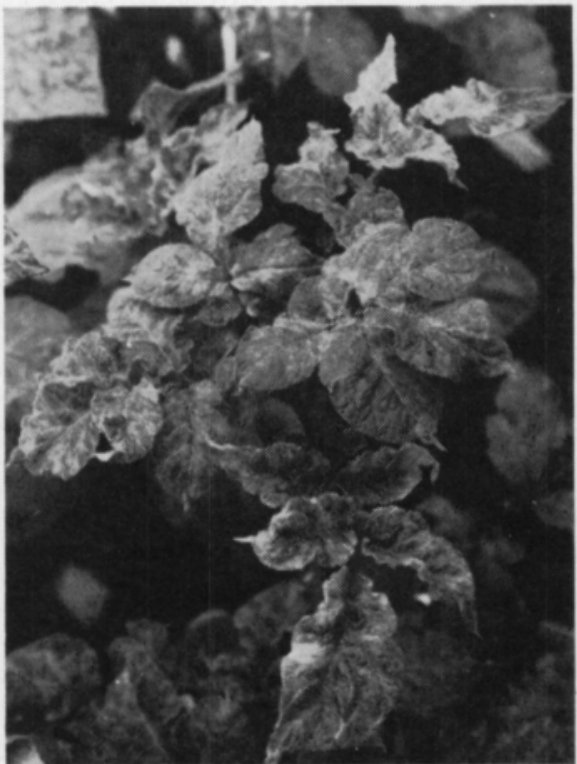

Fig. 44

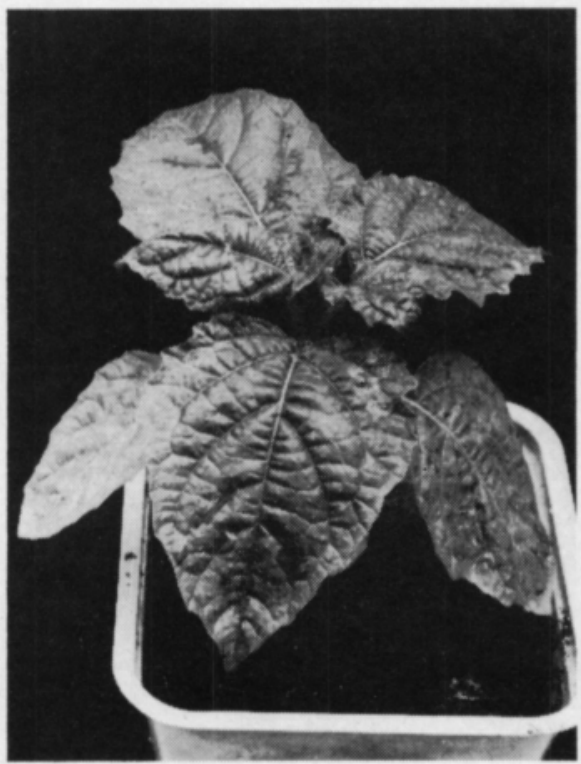

Fig. 45

Fig. 42. Chlorosis and rugosity in potato cv. Pito infected with PVA isolate ASF1.

Fig. 43. Local necrotic lesions in Solanum demissum A 5 days after mechanical inoculation with PVA.

Fig. 44. Severe chlorosis and wrinkling in potato cv. "Black local" infected with PVA isolate ASF4.

Fig. 45. Vein clearing and faint mosaic in Nicandra physaloides infected with PVA isolate ASF2. 


\section{Potato leaf roll virus (PLRV)}

Potato leaf roll virus, $* / *: * / * \mathrm{~S} / \mathrm{S}: \mathrm{S}(\mathrm{I}) / \mathrm{Ap}$, was first described (1916) by QUANJER, van der LEK and OORTWIJN BOTJES (PETERS 1970). The virus has also been named "Potato phloem necrosis virus" (QUANJER 1913).

The virus particles are isometric and are about $24 \mathrm{~nm}$ in diameter. It is transmitted by about 10 aphid species in the persistant manner (MURPHY \& McKAY 1929, MacCARTHY 1954, KENNEDY et al. 1962). The most effective vector is Myzus persicae Sulz. (ROBERT 1971, O'BRIEN \& RICH 1976, KOSTIW 1981) but also the species Aulacorthum solani Kltb., Macrosiphum euphorbiae Thomas (KIRKPATRICK \& ROSS 1952, ROBERT \& MAURY 1970) and Aphis nasturtii Kltb. (BEEMSTER \& ROZENDAAL 1972) may be important.

Potato leaf roll virus is common wherever potatoes are grown (PETERS 1970, BEEMSTER \& ROZENDAAL 1972). It causes rolling of the leaves and a stiff upright habit of the plant (PETERS 1970, O'BRIEN \& RICH 1976). In the plant the virus is distributed in the phloem tissue, where it causes necrosis of the tissue and an accumulation of carbohydrates in the leaves (KOJIMA et al. 1969, PETERS 1970). Necrosis may also occur in the tubers of infected plants (O'BRIEN \& RICH 1976). Potato leaf roll virus may cause yield losses in tubers of up to $70 \%$ but normally the yield loss is between 10 and $40 \%$ due to the compensatory abilities of the crop (TUTHILL \& DECKER 1941, REESTMAN 1970).

The virus has a narrow host range, mainly in the Solanaceae, but some non-solanaceus plants such as Amaranthus caudatus, Celosia argentea, Gomphrena globosa and Nolana lanceolata are susceptible. Moreover, there are several solanaceus hosts, such as Atropa belladonna, Lycopersicon pimpinellifolium, Nicotiana glutinosa, N. rustica and Solanum nigrum, which can become systemically infected with the virus without showing symptoms (NATTI et al. 1953).

\subsection{Occurrence in Finland}

Potato leaf roll virus has been quite recently introduced into Finland and this has occurred naturally via aphids. Observations of the virus were made as early as the 1920's (JAMALAINEN 1946) in some field experiments where imported seed material was used. Natural primary infection of the potato crop was recorded for the first time in Viikki in 1979 when PLRV appeared in a potato crop planted with healthy seed (KURPPA 1981). The symptoms were very clear in the cultivars Sieglinde and Record but also the cvs. Bintje and Pito showed symptoms. The primary symptoms were first seen in younger leaves at the end of July immediately after the time of blooming, later rolling of the leaves was seen in older leaves (Figs. 47 and 49, page 245). Bronzing or red coloration was found particularly in the cvs. Bintje and Record.

The following summer severe secondary symptoms occurred in potato plots planted with seed from plants that had been primarily infected during the previous growing season (Figs. 48 and 50). 
The following PLRV isolates were identified from the virus outbreak in Viikki in 1979:

PLRVSF1, Sieglinde

PLRVSF2, Sieglinde

PLRVSF3, Bintje

PLRVSF4, Record

PLRVSF5, Pito

A new virus outbreak was observed in Sipoo in 1980, where primary and secondary symptoms occurred in abundance in a potato field of about 2 hectares. The PLRV isolate isolated from the field was called PLRVSF6, Record.

During the 1981 growing season the virus was not significantly transmitted in the field because of exceptionally low aphid populations. However, several new virus outbreaks occurred in 1982 and this led to the identification of the following isolates:

PLRVSF7, Prevalent, Renko

PLRVSF8, Juliver, Pyhtää

PLRVSF9, Sv 71118, Pyhtää

PLRVSF10, Provita, Liljendal

PLRVSF11, Saturna, Loviisa

The isolates PLRVSF8 and 9 originated from experimental material but the other isolates came from large commercial potato fields.

\subsection{Properties of the virus isolates}

All of the isolates induced easily visible symptoms in 14-20 days in Physalis floridana and Datura stramonium when transmitted to them by $M$. percicae (Figs. 51-53). The isolates originally isolated in Viikki in 1979 caused severe or moderate stunting and interveinal chlorosis in the test plants and were classified into severe or moderate isolates according to WEBB et al. (1952) and MacCARTHY (1963). The isolates PLRVSF6, 7 and 11 were mild and 8,9 and 10 moderate according to the same classification.

In a field experiment the virus isolate PLRVSF1 caused very significant losses in tuber yield in the three generations following primary infection (Table 22).

When comparisons were made, tuber numbers and yields from the first secondarily infected plant generation were $29.2 \%$ and $53.8 \%$ lower than the tuber numbers and yields of the preceding crop. In the following generations the losses were the following: $43.5 \%$ fewer tubers and $77.3 \%$ lower yield in the 2 nd generation and $44.3 \%$ fewer tubers and $77.6 \%$ lower yield in the 3rd generation. 
Table 22. The effect of secondary PLRV infection on tuber number and yield of the cv. Sieglinde in the three generations following primary infection by isolate PLRVSF1 in a field experiment in Viikki.

\begin{tabular}{lcccc}
\hline & \multicolumn{2}{l}{ Tuber number/plant } & \multicolumn{2}{l}{ Tuber yield/plant } \\
Treatment & mean & variation & mean g & variation g \\
\hline Healthy control & 19.95 & $14-25$ & 2055 & $1620-2460$ \\
1st generation & 14.03 & $8-20$ & 950 & $370-1680$ \\
2nd " & 11.28 & $6-18$ & 466 & $100-880$ \\
3rd & 11.12 & $6-16$ & 457 & $190-820$ \\
\hline
\end{tabular}

$\mathrm{F}$ tuber number $=76.8^{\mathrm{xxx}} \quad \mathrm{LSD}_{\mathrm{r} 0.05}=1.30$

$\mathrm{F}$ tuber yield $=390^{\mathrm{xxx}} \quad \mathrm{LSD}_{\mathrm{t} 0.05}=107(\mathrm{~g})$

\subsection{Virus identification}

The identification of PLRV in potatoes was initially based on symptom observation and "the tuber indexing method", which was completed with the use of $P$. floridana as the test plant (WEBB et al. 1952, HEPP \& de ZOETEN 1978). The callose test (Igel-Lange test), which showed abnormal starch accumulation in the infected tubers, became a routine test for PLRV identification in the 1950's (IGEL \& LANGE 1953, SPRAU 1957). The test was widely used until the end of the 1970's (de BOKX 1967, ZAMBONI et al. 1977, MAAT \& de BOKX 1978) when the ELISA method (CLARK \& ADAMS 1977) started to supersede it (CASPER 1977a, MAAT \& de BOKX 1978, GUGERLI 1979, TAMADA \& HARRISON 1980, CLARKE 1981, MARCO 1981).

The possibilities for using electron microscopy in the rapid identification of PLRV are restricted but promising attempts have been made by SARKAR (1975). Virus particles can be recognized in thin section preparates made from infected plant tissue (Figs. 64 and 65, page 252) but the method is unsuitable for routine work. To separate purified virus particles from other similar particles or to demonstrate serological relationships between the particles "the immunosorbent electron microscopy" and "antibody-virus mixture" methods (ROBERTS \& HARRISON 1979, ROBERTS et al. 1979) have been used.

All of the PLRV isolates tested with the ELISA method can be reliably identified in secondarily infected dormant and sprouted tuber and potato leaf tissue. For identification two reagents were used; a commercial one from the Boehringer Mannheim Ltd and an indigenous one prepared from unpure antiserum obtained from the Scottish Crop Research Institute (SCRI) (TAMADA \& HARRISON 1980). Some serological variation between the isolates was found although the reagents were closely related to each other. However, the results obtained with the commercial reagent showed higher specificity because of lower background readings with this test. This could be demonstrated by value of the relation $\mathrm{A}_{\mathrm{v}} / \mathrm{A}_{\mathrm{Ho}}$ which is a ratio between virus infected and healthy plant samples (Table 23). 
Table 23. The absorbance values obtained with the ELISA test in undiluted and diluted healthy or PLRV infected potato leaf sap. For the identification reagents from the Boehringer Mannheim (I) and from the SCRI (II) were used. Substrate incubation was carried out at $20 \mathrm{C}$ for $1 \mathrm{~h}$.

\begin{tabular}{|c|c|c|c|c|c|c|c|c|}
\hline \multirow[b]{3}{*}{ Sample } & \multicolumn{8}{|c|}{ Sample dilution and absobance values } \\
\hline & \multicolumn{2}{|r|}{$10^{\circ}$} & \multicolumn{2}{|c|}{$10^{-1}$} & \multicolumn{2}{|c|}{$10^{-2}$} & \multicolumn{2}{|c|}{$10^{-3}$} \\
\hline & I & II & I & II & I & II & I & II \\
\hline PLRVSF1 & 1.420 & 1.139 & .560 & .346 & .104 & .109 & .030 & .037 \\
\hline 2 & 1.008 & .761 & .324 & .228 & .069 & .091 & .021 & .036 \\
\hline 4 & 1.179 & .917 & .416 & .314 & .117 & .107 & .027 & .034 \\
\hline 7 & 1.440 & 1.311 & .531 & .422 & .099 & .094 & .032 & .044 \\
\hline 8 & 1.032 & 1.146 & .404 & .331 & .084 & .078 & .024 & .030 \\
\hline 9 & 1.941 & 1.642 & 1.160 & .778 & .311 & .138 & .077 & .069 \\
\hline 10 & 1.670 & 1.440 & .717 & .630 & .161 & .114 & .043 & .051 \\
\hline 11 & 1.430 & 1.230 & .599 & .495 & .097 & .088 & .024 & .038 \\
\hline $\begin{array}{l}\text { Mean value for } \\
\text { healthy samples }\end{array}$ & .051 & .157 & .031 & .072 & .016 & .040 & .012 & .031 \\
\hline $\mathrm{A}_{v} / \mathrm{A}_{\mathrm{Ho}_{\mathrm{o}}}$ & 27.25 & 7.63 & 10.25 & 2.82 & 2.54 & .65 & .67 & .27 \\
\hline
\end{tabular}

\subsection{Virus purification and particle properties}

Several methods have been developed for the purification of potato leaf roll virus (PETERS 1967, KOJIMA et al. 1969, MAAT \& de BOKX 1978, HEPP \& de ZOETEN 1978, ROWHANI \& STACE-SMITH 1979, TAKANAMI \& KUBO 1979, CLARKE 1981). MURAYAMA and KOJIMA (1974) were the first to prepare PLRV antiserum.

The virus could be purified from infected $P$. floridana leaves by the method of TAKANAMI \& KUBO (1979) and from potato leaves by a method slightly modified from the method described by CLARKE (1981). The former method was discontinued, however, because of the high costs of the driselase enzyme which is needed in the course of the purification procedure.

For higher yields of purified virus, the CLARKE (1981) method was modified in that the ELISA test was used following all of the steps in the procedure. The critical steps in the method were the polyethylene glygol precipitation and the release of the virus from the precipitate into the buffer solution. The yields of purified virus could be gradually increased and the highest yield obtained was $0.7 \mathrm{mg} / \mathrm{kg}$ leaf matter compared to $1.1 \mathrm{mg} / \mathrm{kg}$ leaf matter with the method of TAKANAMI \& KUBO (1979).

In linear gradients of sucrose $(10-40 \% \mathrm{w} / \mathrm{v})$ the virus moved to one narrow band about $35 \mathrm{~mm}$ from the meniscus after 4 hs of centrifugation at $24000 \mathrm{rpm}$ in a Beckman SW-27 rotor (Fig. 46).

The A $260 / 280$ value determined for the virus was 1.75 . In electron micrographs the purified virus particles were hexagonal with a diameter of about $25 \mathrm{~nm}$ (Fig. 66, page 252). 


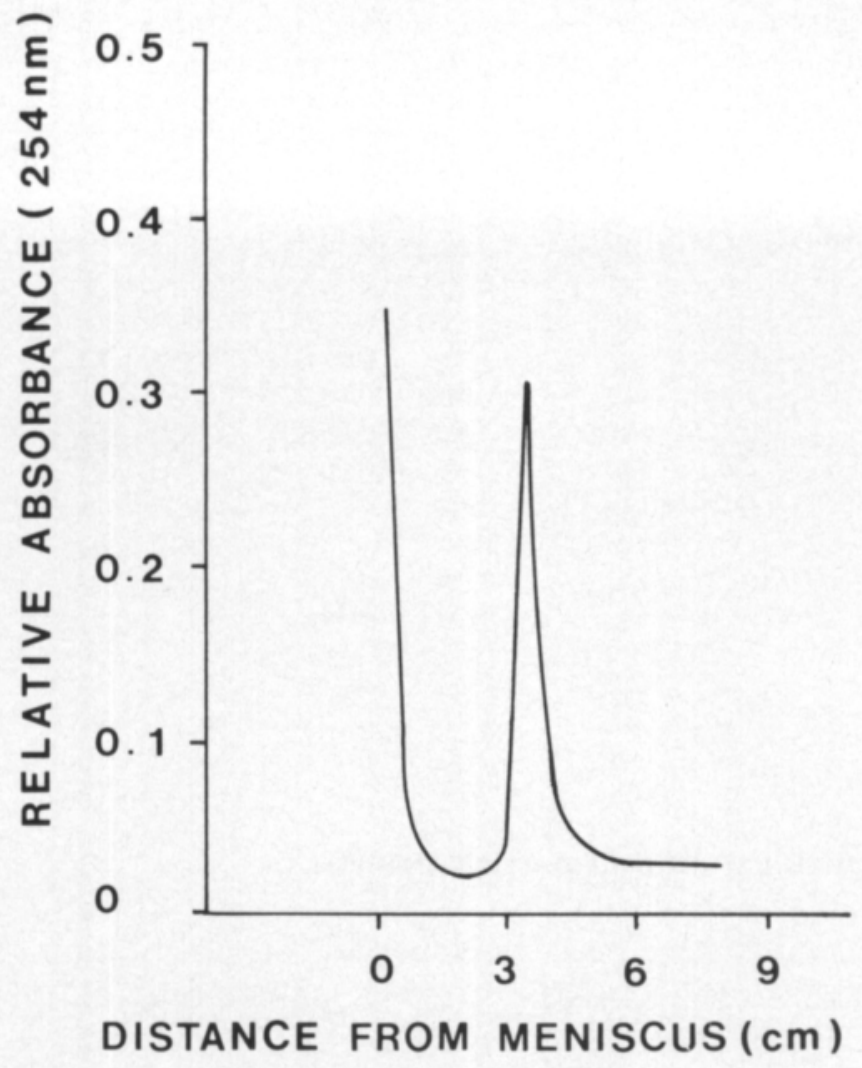

Fig. 46. Scanning pattern of partially purified PLRV obtained in the ISCO density-gradient fractionator after one cycle of density-gradient centrifugation for $4 \mathrm{~h}$ at $24000 \mathrm{rpm}$ (Beckman SW-27 rotor) in $10-40 \% \mathrm{w} / \mathrm{v}$ linear sucrose gradients. 

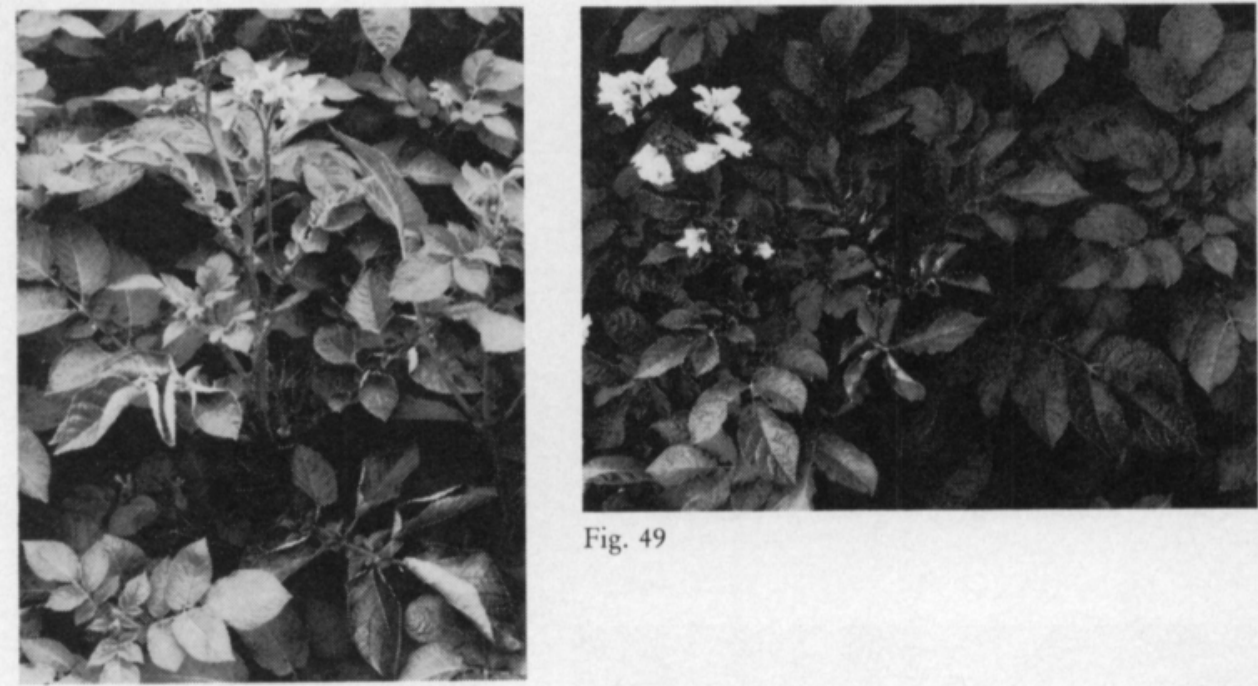

Fig. 49

Fig. 47
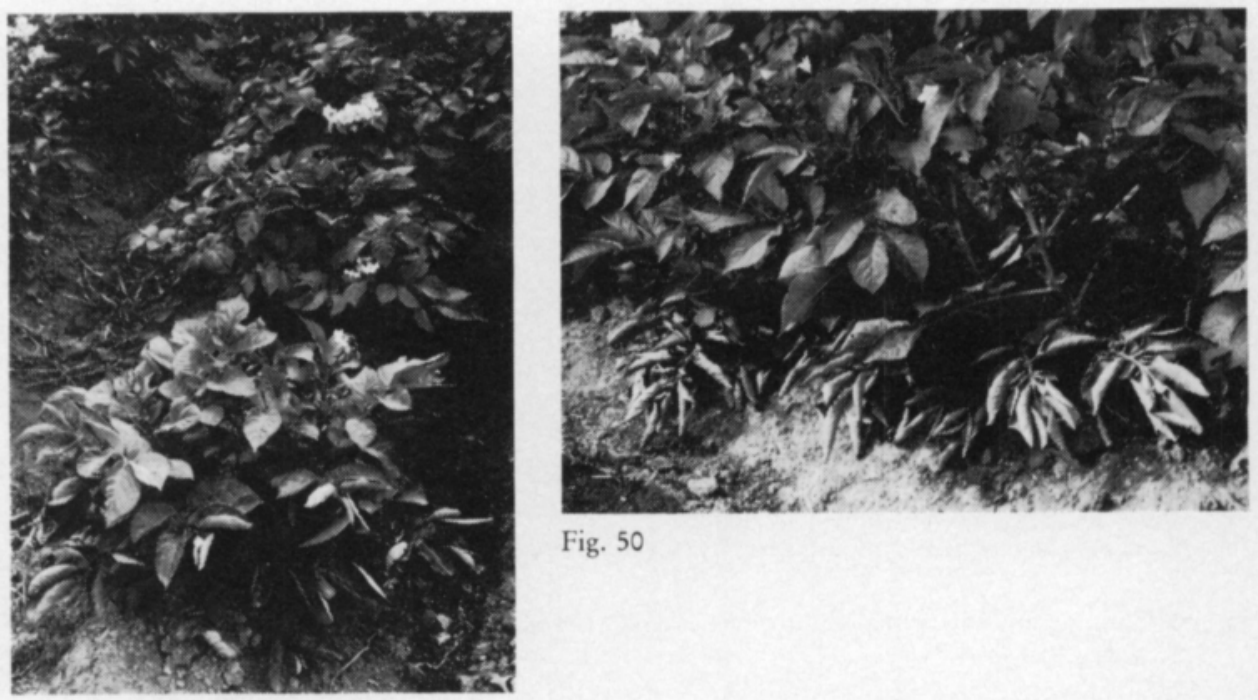

Fig. 50

Fig. 48

Figs. 47 and 49. Primary symptoms of PLRV in potato cv. Pito (Fig. 47) and cv. Saturna (Fig. 49).

Figs. 48 and 50. Secondary symptoms of PLRV in potato cv. Record (Fig. 48) and cv. Sieglinde (Fig. 50). 


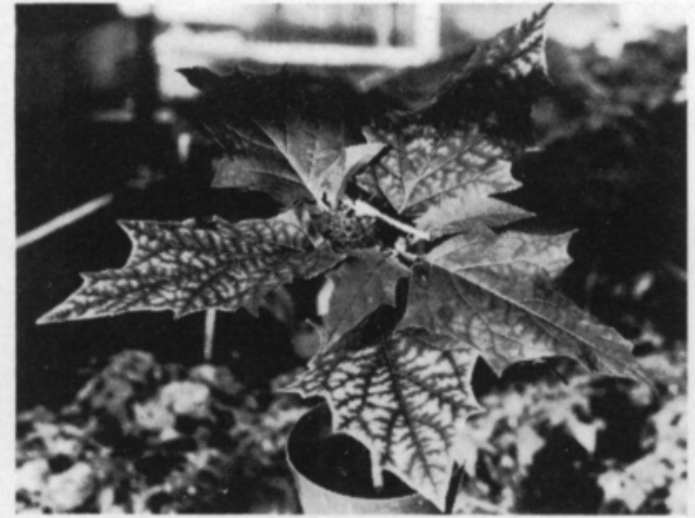

Fig. 51

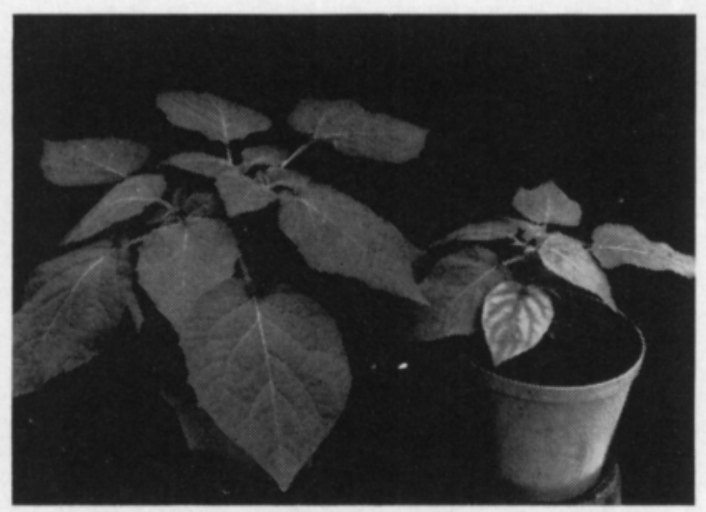

Fig. 52

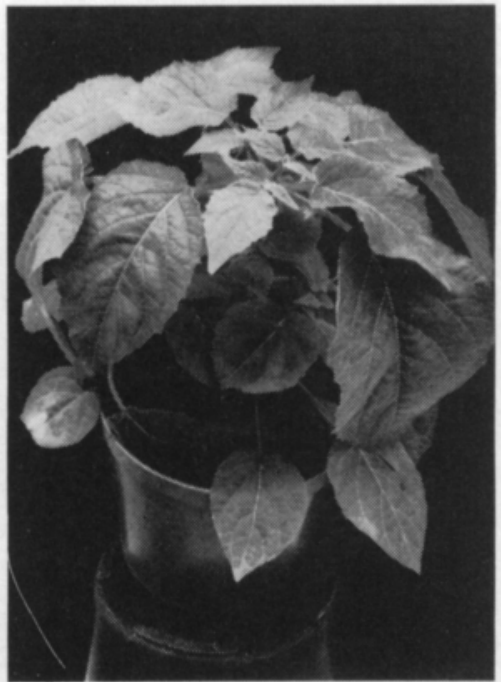

Fig. 53

Fig. 51. Interveinal chlorosis in Datura stramonium 4 weeks after infection with the PLRV isolate SF2.

Fig. 52. PLRV, isolate SF1, symptoms in Physalis floridana 3 weeks after aphid transmission.

Fig. 53. Stunting and interveinal chlorosis in Physalis floridana 6 weeks after infection with the PLRV isolate SF1.

\section{Tobacco rattle virus (TRV)}

Tobacco rattle virus, $\mathrm{R} / 1: 2.3+0.6$ to $1.3 / 5: \mathrm{E} / \mathrm{E}: \mathrm{S} / \mathrm{Ne}$, was first described by QUANJER (1943) as Tobacco partridge virus. Other synonyms found in the literature are Aster ringspot virus, Belladonna mosaic virus, Potato corky ringspot virus, Potato stem mottle virus, Ratel virus, Tabakmauche Virus, Tabak Streifen und Kräuselkrankheit Virus (HARRISON 1970), Potato spra- 
ing virus (EDDINS et al. 1946), Nicotiana virus 5 (SMITH 1957) and Tobacco virus 11 (JOHNSON 1936).

The virus particles are straight tubes of two predominant lenghts, the longer being c. $190 \mathrm{~nm}$ and the shorter being c. $45-115 \mathrm{~nm}$ depending on the isolate. The fraction of shorter particles consists of particles of $1-3$ different lengths. The diameter of all of the particles is c. $25 \mathrm{~nm}$.

The virus is transmitted by Trichodorid nematodes (SOL \& SEINHORST 1961, van HOOF 1968, TAYLOR \& CADMAN 1969) and some of the isolates are also readily transmitted by inoculation with plant sap (HARRISON 1970).

Tobacco rattle virus occurs in Europe, U.S.A., Brazil, Japan (HARRISON 1970) and in New Zealand (JONES \& YOUNG 1978). Many strains are described which differ from each other in the symptoms they induce in host plants and also in their serological properties (CADMAN \& HARRISON 1959, HARRISON \& WOODS 1966, LISTER \& BRACKER 1969, KURPPA et al. 1981).

In potato tubers TRV causes "spraing" or "corky ringspot". This consists of rings of corky tissue in the tuber flesh which can make the crop unsaleable for human consumption (HARRISON \& ROBINSON 1978). In potato plants the virus causes "stem mottle" and mottling of the leaves. Yellow areas may appear in the leaves resembling the symptoms caused by Potato aucuba virus. Some potato cvs. also show stunting, leaf deformation and even necrosis (HARRISON \& ROBINSON 1978).

The tubers produced by the diseased plants are only partially infected. According to BEEMSTER \& ROZENDAAL (1972) about half of the crop consists of TRV infected tubers when the seed potatoes were all affected with "stem mottle" disease as compared to $0-30 \%$ diseased tubers produced by seed potatoes affected with "spraing".

In addition to potatoes TRV causes economically important damage to tobacco, peppers, sugar beets and several ornamental plants, particularlv bulbous ornamentals (HARRISON 1970, HARRISON \& ROBINSON 1978).

The host range of TRV is very wide. More than 400 species in dicotyledonous and monocotyledonous families can be infected (SCHMELZER 1957), including a wide range of weed species which are able to maintain the virus in the soil (DAVIS \& ALLEN 1975).

The virus can be transmitted to several plant species mechanically or by nematodes. Necrotic local lesions are produced by TRV in many hosts, but only about half become infected systemically. Suitable local assay hosts are Chenopodium amaranticolor, C. quinoa and Phaseolus vulgaris. TRV infects systemically several species in the family Nicotiana, of which N. clevelandii is the most suitable for maintaining the virus and for virus purification (SCHMELZER 1957). Transmission from potato tubers showing "spraing" symptoms to susceptible host species is often difficult (HARRISON \& ROBINSON 1978).

Severe difficulties have been found with the serological identification of TRV. The virus concentration in potato tubers is very low. Also the wide serological variability and the occurence of NM-isolates (these consist of infective RNA only) makes serological testing unreliable (HARRISON \& ROBINSON 1982). 


\subsection{Symptoms caused by the isolates occurring in Finland}

Tobacco rattle virus was isolated from three tuber lots and transferred to C. amaranticolor, C. quinoa and $N$. clevelandii plants via mechanical inoculation with tuber sap. The origin of the isolates were as follows:

TRVSF1 Pito, Jurva

1980

TRVSF2 Bintje, Renko 1981

TRVSF3 Record, Loppi 1981

Eight tuber lots showing "spraing" symptoms were studied but TRV could not be isolated from the rest of the possibly infected samples using the normal method of mechnical inoculation to test plants. The virus caused only mild mottling symptoms in plants grown from virus infected tubers or else no symptoms were found.

Virus particles were seen in electron micrographs made from C. quinoa sap where numerous $(>10)$ local lesions had developed in inoculated leaves. In the C. quinoa leaves where only a few local lesions $(<3)$ existed no virus particles were found.

The particle-forming isolates (3) caused the following similar symptoms in selected test plants:

Chenopodium amaranticolor: Necrotic local pinpoint lesions in 3-5 days; not systemic (Fig. 54).

C. quinoa: Necrotic local lesions in 3-5 days; not systemic (Fig. 56).

Phaseolus vulgaris cv. Stella: Necrotic local pinpoint lesions in 2-4 days; not systemic (Fig. 58).

Pisum sativum cv. English sword: Necrotic local lesions $1-4 \mathrm{~mm}$ in diameter in 5-7 days; not systemic.

Vicia faba cv. Pirhonen: Necrotic local lesions in 5-7 days; not systemic (Fig. 57).

Nicotiana clevelandii: Occasional chlorotic or necrotic lesions in 3-5 days followed by faint systemic mottle in 5-7 days.

N. glutinosa: Large necrotic local lesions in 3-4 days followed by systemic necrotic spots and leaf distortion in 10-14 days.

N. tabacum cv. Samsun: Large necrotic local lesions in 3-5 days followed by systemic mottling and leaf distortion in 8-14 days (Fig. 55).

The symptoms in the test plants were similar to those caused by the PRN isolate (CADMAN \& HARRISON 1959, HARRISON \& NIXON 1959).

\subsection{Sap properties and virus purification}

The thermal inactivation point and the dilution end point values were the same for all of the isolates. The virus lost its infectivity when heated to $85 \mathrm{C}$ or diluted to $10^{-7}$.

When the virus was purified from systemically infected leaves of $N$. clevelandii by the method of KURPPA et al. (1981) yields of between 65-85 
$\mathrm{mg} / \mathrm{kg}$ leaf material of purified virus were obtained. In density gradient centrifugation in linear sucrose gradients of $10-40 \mathrm{w} / \mathrm{v}$ sucrose the partially purified virus moved to two dominant bands. In electron micrographs most virus particles had a length of v. 190 or c. $75 \mathrm{~nm}$ and a diameter of $24 \mathrm{~nm}$ (Fig. 67 , page 252).

\subsection{Serological properties}

No antisera were prepared for the virus isolates but the reactions of all purified virus preparates were tested against 4 known and one unknown TRV antisera and a PEBV (Pea early browning virus, British isolate) antiserum according to the EM-serological AMV method (Table 24, Figs. 68 and 69).

Table 24. Heterologous reaction of $5 \mathrm{TRV}$ antisera and a PEBV antiserum to 3 indigenous TRV isolates in the EM-serological AMV test. Virus concentrations of $10 \mu \mathrm{g} / \mathrm{ml}$ were used.

\begin{tabular}{lrrrrrr}
\hline \multirow{2}{*}{ Antigen } & \multicolumn{7}{c}{ Antisera and their titers } \\
& CAM & ORE & PRN & SYM & 1627 & PEBV \\
\hline TRV SF1 & 64 & 16 & 512 & 32 & 16 & $<16$ \\
TRV SF2 & 128 & 32 & 1024 & 32 & 32 & $<16$ \\
TRV SF3 & 32 & 16 & 256 & $<16$ & 32 & $<16$ \\
\hline
\end{tabular}

The origin of the virus isolates and their homologous titers is as follows:

\begin{tabular}{|c|c|c|c|}
\hline CAM & strain & (HARRISON \& WOODS 1966) & $1 / 2048$ \\
\hline ORE & $"$ & (LISTER \& BRACKER 1969) & $1 / 512$ \\
\hline PRN & " & (HARRISON \& NIXON 1959) & $1 / 1024$ \\
\hline SYM & ” & (KURPPA et al. 1981) & $1 / 1024$ \\
\hline 1627 & $”$ & (KURPPA, unpublished) & $1 / 512$ \\
\hline PEB & ritish isolate & (HARRISON 1966) & $1 / 1024$ \\
\hline
\end{tabular}

All of the TRV isolates studied were serologically closely related to the PRN isolate; two of them being almost identical to it. 


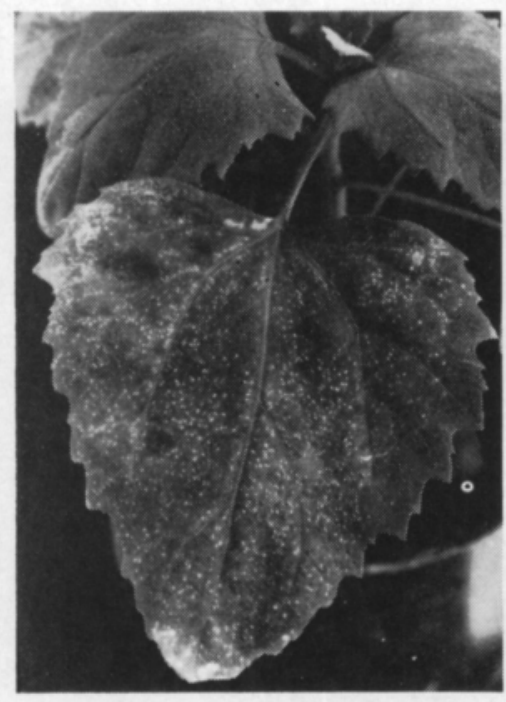

Fig. 54

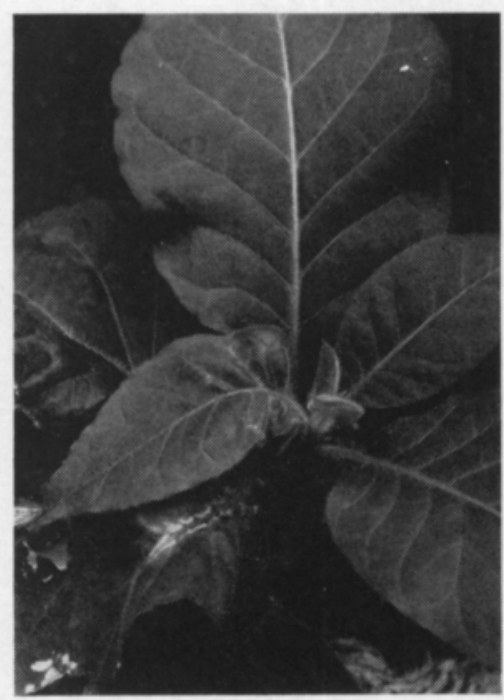

Fig. 55

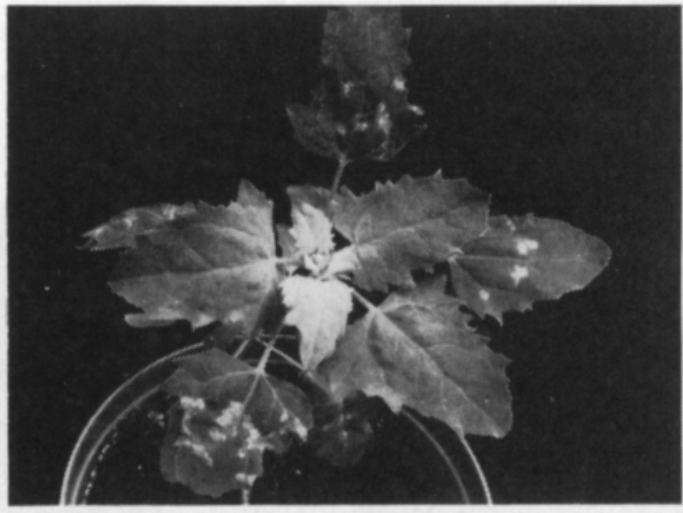

Fig. 56

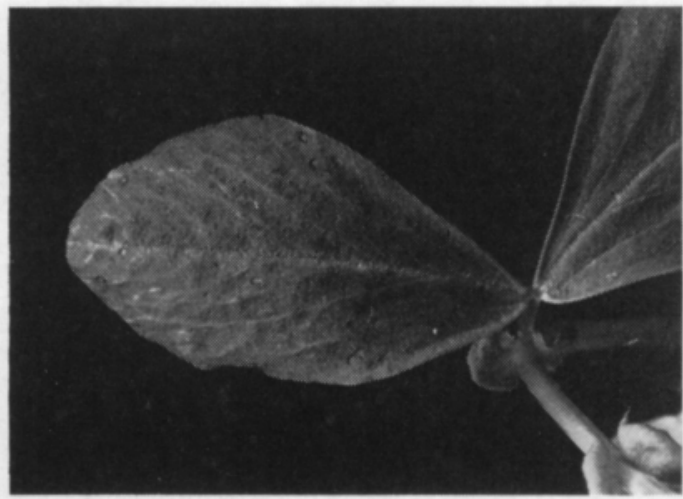

Fig. 57

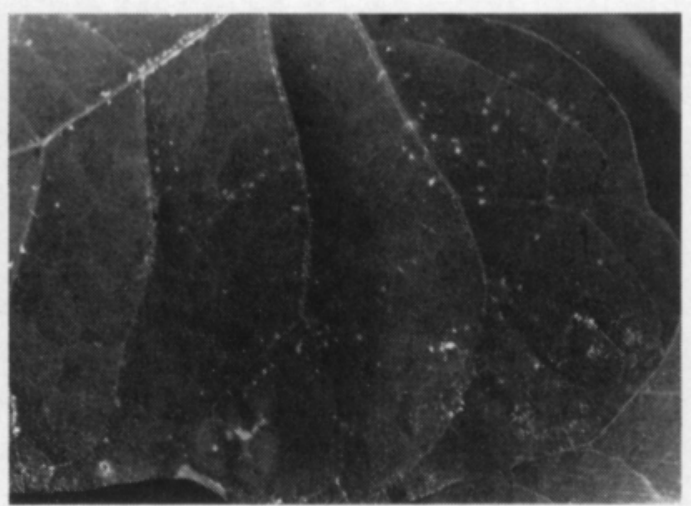

Fig. 58

Figs. 54-58. TRV symptoms in test plants as caused by the isolate TRVSF2. Local pinpoint lesions in Chenopodium amaranticolor (Fig. 54), systemic leaf and top necrosis in Nicotiana tabacum cv. Samsun (Fig. 55), local necrotic lesions in C. quinoa (Fig. 56) and Vicia faba cv. Pirhonen (Fig. 57) and local pinpoint lesions in Phaseolus vulgaris cv. Stella (Fig. 58). 


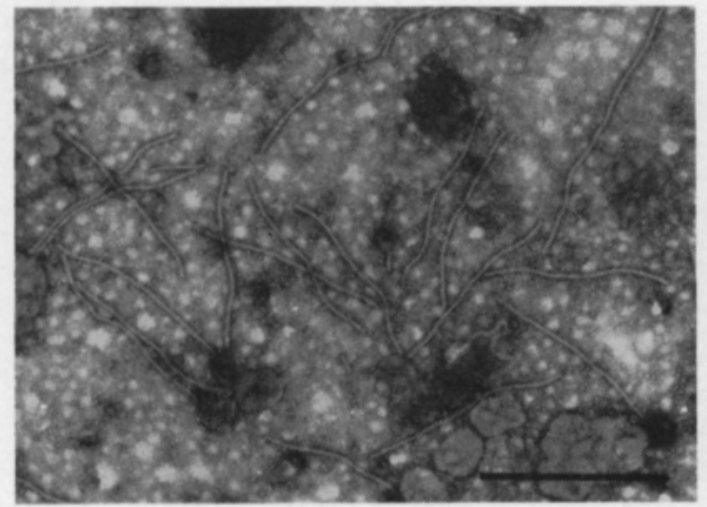

Fig. 59

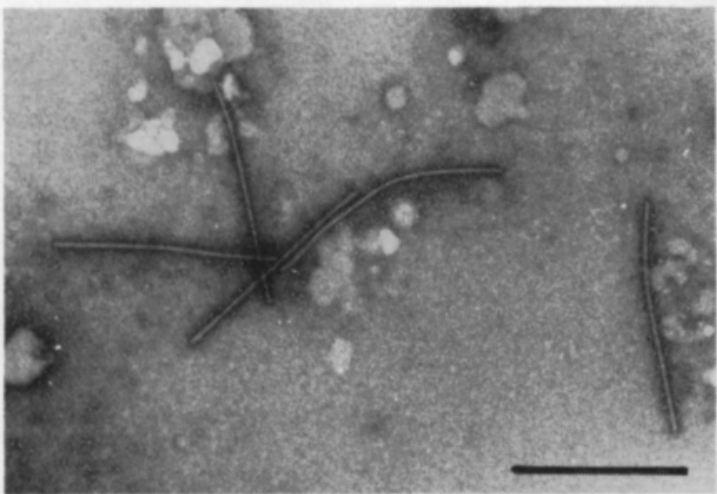

Fig. 60

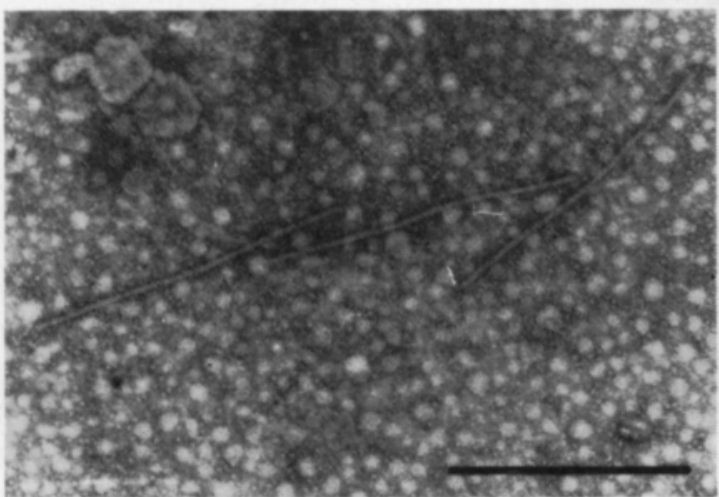

Fig. 61

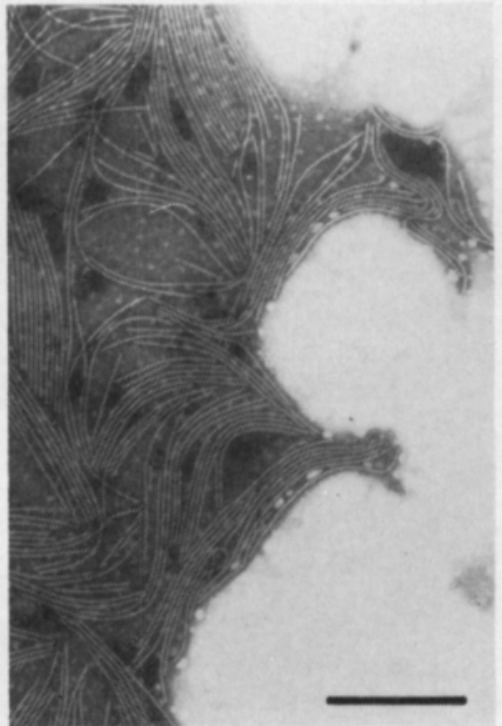

Fig. 62

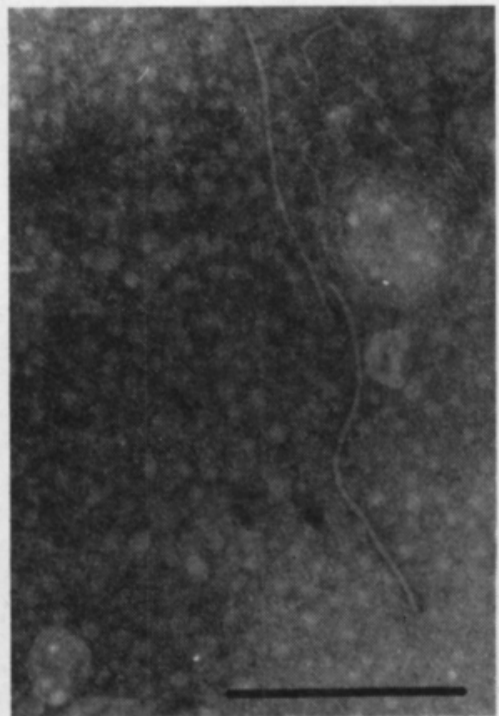

Fig. 63

Figs. 59-63. Electron micrographs of rod shaped potato virus particles. Preparations stained with $1.5 \%$ PTA, pH 6.5. PVX particles in Nicotiana glutinosa sap (Fig. 59), PVS particles in $N$. debneyi sap (Fig. 60), PVM particles in tomato sap (Fig. 61), partially purified PVY preparate (Fig. 62) and PVA particles in N. tabacum cv. Samsun sap (Fig. 63). Bar represents $500 \mathrm{~nm}$. 


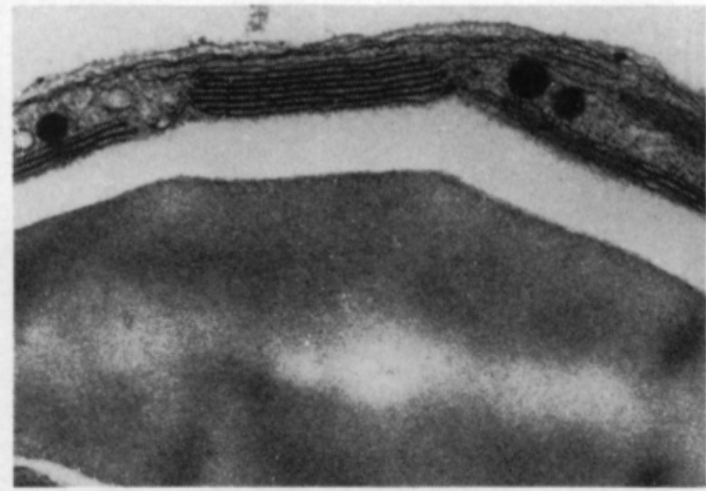

Fig. 64

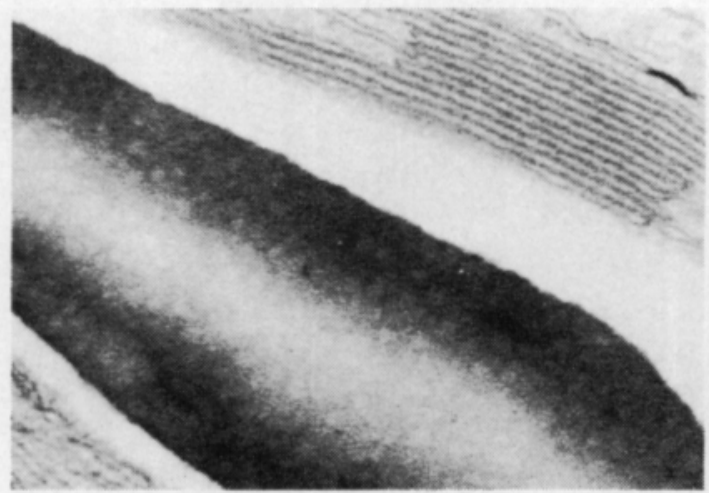

Fig. 65

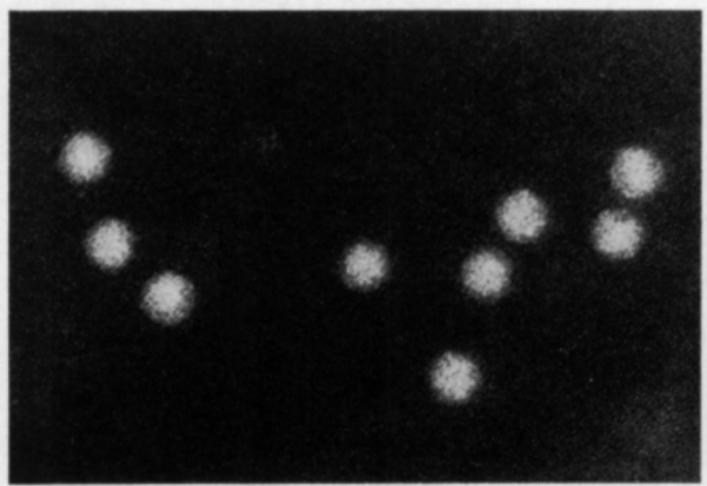

Fig. 66

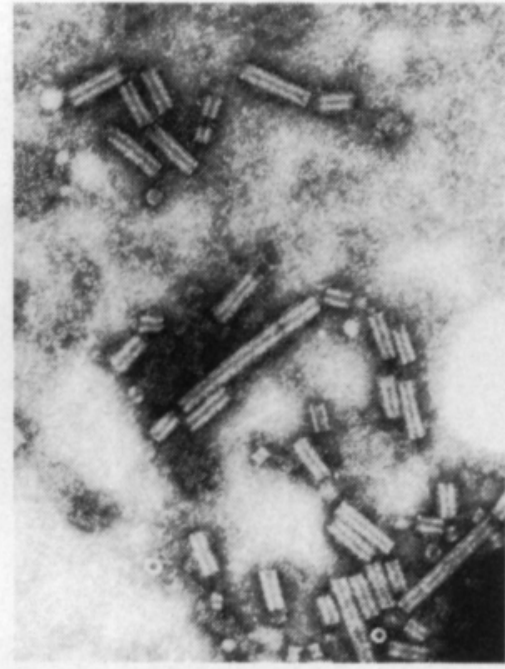

Fig. 67

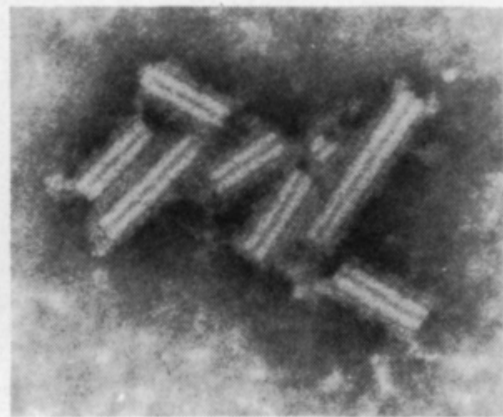

Fig. 68

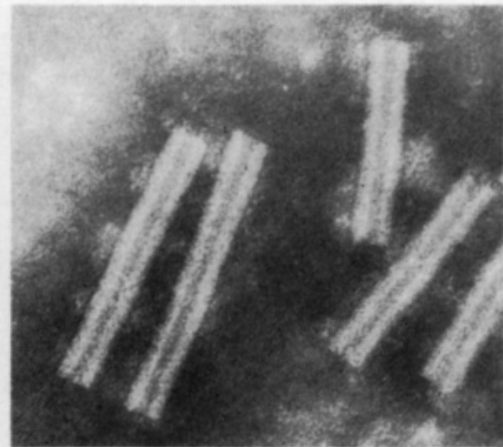

Fig. 69

Figs. 64 and 65. Electron micrographs of starch grains in thin sections of potato phloem tissue. Healthy plant (Fig. 64) and PLRV infected plant (Fig. 65).

Fig. 66. Electron micrograph of purified preparation of PLRV.

Figs. 67-69. Electron micrographs of TRV-particles. Particles of different length in Nicotiana clevelandii sap (Fig. 67). Particles in purified preparate totally coated (Fig. 68) or partially coated (Fig. 69) with antibodies for TRV-PRN isolate. 


\section{Different methods of identifying potato viruses}

\section{Methodological developments in virus identification}

\subsection{Traditional methods}

The agents causing economically important viral diseases in potatoes could be identified with the use of susceptible test plants many years ago but this method is unsuitable for large scale routine work. Promising results with serological identification of potato viruses were obtained as early as the 1920's and 1930's by DVORAK (1927), BEALE (1931) and CHESTER (1935).

Routine serological testing of potato viruses was first started in the Netherlands (van SLOGTEREN 1955, van SLOGTEREN \& van SLOGTEREN 1957 ) and as well, the mass production of potato virus antisera originated there. Attempts at serological virus identification were also carried out in the Scandinavian countries (KRISTENSEN 1955, AURA 1957) in the 1950's.

With the simple chloroplast agglutination method potato viruses $\mathrm{X}, \mathrm{S}$ and $M$ were easily detectable in leaf sap but this method was unsuitable for viruses $\mathrm{A}, \mathrm{Y}$ and PLRV because of their low concentration in plant sap or the lack of an antiserum for them (BARTELS 1957, VULIČ \& ARENZ 1963, de BOKX 1974, SYNAK 1975). To test viruses A and Y the A6 cut leaf test was introduced by KÖHLER (1953) and was developed further by ARENZ \& HUNNIUS (1961), de BOKX (1964) and KELLER \& BÉRCES (1966).

For PLRV identification in potato tubers a callose test was developed (IGEL \& LANGE 1953, de BOKX 1967). This test remained widely used until an antiserum for the virus was produced by MURAYAMA et al. (1973) and the Enzyme-Linked Immuno Sorbent Assay (ELISA) techniques, with their high specificity were developed for routine work (CLARK \& ADAMS 1977, CASPER 1977a).

To improve testing methods based on the chloroplast agglutination or the precipitin principles, modifications such as the bentonite-flocculation test, the latex-agglutination test, the barium sulphate test BOZICEVICH et al. 1963, SCOTT et al. 1963, BERCKS 1967, KAHN et al. 1967, ABU-SALIH et al. 1968 a, 1968b), the passive haemagglutination test and the complement fixation test (SAITO \& IWATA 1964, GUNNINGHAM et al. 1966, KRYLOW \& GNUTOVA 1974) were developed. The latex-agglutination test is still widely used in the routine identification of potato viruses (GOUDSWAARD et al. 1978, KHAN \& SLACK 1978, KOENIG \& BODE 1978, QUERFURTH \& PAUL 1979, TALLEY et al. 1980).

Because of non-specific reactions found in the A6 test caused by viruses other than PVA and PVY (BARTELS 1970, de BOKX \& CHRZANOWSKA 1972) or the failure of a reaction to occur with some PVY isolates (de BOKX et al. 1975) new susceptible local hosts were studied for use in PVA and PVY identification. Solanum chacoence (TE 1 ) (TROFIMETS et al. 1967, BLOTSKAYA 1972, de BOKX 1974) and S. demissum Y (CHRZANOWSKA et al. 1977) were found to be highly susceptible to PVY but not to PVA and therefore did not supersede the A6 test in routine work. 
Long filamentous virus particles are either not able to diffuse into agar gels or else their rate of movement through the gels is very slow (van REGENMORTEL 1966, NOORDAM 1973). The development of techniques to degrade intact filamentous virus particles with a chemical or physical treatment into protein fragments or subunits (PURCIFULL \& SHEPHERD 1964) made gel diffusion methods suitable for potato virus identification. Chemicals that have been used to dissociate elongated virus particles include pyridine (SHEPARD \& SECOR 1969), pyrrolidine (SHEPARD 1970b) and ethanolamine (PURCIFULL \& SHEPHERD 1964, PURCIFULL \& GOODING 1970). Detergents that have been used to degrade elongated virus particles include sodium dodecyl sulphate (SDS) (GOODING \& BING 1970, PURCIFULL \& BATCHELOR 1977, RICHTER et al. 1979), sodium dibutylnaphtalate sulphonate (Leonil SA) (HAMILTON 1964) and sodium-N-methyl-Noleolyl-taurate (LANGENBERG \& BALL 1972). Also ultrasonic treatment has been used to degrade the particles (TOMLISON \& WALKEY 1967).

\subsection{Labelled antibody techniques}

In serological reactions the labelling of antibodies with active or passive labels has decisively increased reaction sensitivity. For antibody labelling ferritin (BALL 1974), fluorescent dye (JOHNSON et al. 1978) or metal labels (SOINI \& HEMMILÄ 1979) and enzyme labels (ENGVALL \& PERLMANN 1972, van WEEMEN \& SCHURS 1972, VOLLER et al. 1976) have been used. Of these methods, the ELISA test (enzyme-linked immunosorbent assay) (CLARK \& ADAMS 1977) is the most widely used in routine work because viruses, which occur in a very low concentration in plants or even in insect vectors, can be reliably identified with it (CASPER 1977a, 1977b, BARBARA et al. 1978, CERA et al. 1978, LISTER \& ROCHOW 1979, CLARKE et al. 1980).

The most common usage of the ELISA test employs a direct method (CLARK \& ADAMS 1977) in which virus specific Ig conjugated with the enzyme alkaline phosphatase (or a similar enzyme) is used in a double antibody sandwich. When a chromogenic substrate, usually p-nitrophenyl phosphate, is used a bright yellow color denotes a positive reaction. The absorbance of the color can be measured with a photometer at a wavelength of $405 \mathrm{~nm}$. If a fluorogenic substrate is used (TORRANCE \& JONES 1982) special equipment is needed to read the fluorescense values.

In indirect ELISA methods, anti-Ig antibodies or a suitable protein which tends to link with antibodies are labelled with the enzyme (instead of antivirus antibodies). In some modifications of the test antibodies produced by two different animal species are needed (BAR-JOSEPH \& MALINKSON 1980, van REGENMORTEL \& BURCKARD 1980) but also a fractionated antiserum raised in one animal species (BARBARA \& CLARK 1982) or an antiserum with a serum complement may be sufficient (TORRANCE 1980b).

The indirect ELISA methods have some advantages over the direct ELISA methods such as higher sensitivity, lower or wider specificity (depending on which is needed) and the availability of the same enzyme conjugate for the 
identification of any virus wanted (TORRANCE \& JONES 1981, BARBARA \& CLARK 1982).

The ELISA method and its modifications (CLARK \& ADAMS 1977, KOENIG 1981, BARBARA \& CLARK 1982, TORRANCE \& JONES 1982) are now the most sensitive methods available for plant virus identification and have quickly replaced the previous routine methods in potato virus determination.

\section{The suitability of these methods for potato virus identification as tested in Finland}

\subsection{Chloroplast agglutination methods and the cut leaf method}

The chloroplast agglutination test was initially used as a routine method when virus transmission studies and virus isolations were carried out. A bentonite-flocculation modification of the method did not significantly increase the visibility of the agglutination reaction or decrease the amount of the non-specific reaction. Similarly $0.4 \%$ sodium sulphite $\left(\mathrm{Na}_{2} \mathrm{SO}_{3}\right)$ added to the diluted antisera solutions did not have any positive effect on the reaction reliablity (Table 25 ).

Potato viruses $\mathrm{X}, \mathrm{S}$ and $\mathrm{M}$ could be reliably identified in secondarily infected potato leaf sap but only a few strong PVY reactions were detected. Great differences between the cultivars were not detected. When normal potato samples containing primarily infected tubers were tested the results obtained with the chloroplast agglutination test were in some cases significantly different from those obtained with more modern techniques as demonstrated later in this paper.

When results of comparable cut leaf tests obtained with $\mathrm{A} 6$ and $\mathrm{TE}_{1}$ leaves were compared with each other some inconsistency was found. In some cases the results were comparable but significant differences also existed (Table 26).

Of 3389 potato leaf samples tested comparably with both test plants 1080 leaves $(31.8 \%)$ showed definite positive reactions (necrotic lesions). The $\%$ of infected leaves of $\mathrm{A} 6$ was 40.2 and that of $\mathrm{TE}_{1}$ was 38.2. The unreliable or wrong $\%$ of the A6 tests was $20.6 \%$ as compared to $18.2 \%$ for the $\mathrm{TE}_{1}$ test. When simultaneous positive reactions were read for both test plants the final results contained an error percentage of about $20 \%$.

Several factors were found to contribute to this large error percentage. A6 leaves reacted with necrotic local lesions to the ringspot isolates of PVX but physiologically old A6 leaves did not react sensitively to infection by PVA and PVY.

$\mathrm{TE}_{1}$ leaves may react to infection by some isolates of PVS and PVM. However, if small leaves or physiologically old leaves are used positive reactions may be overlooked.

Some of the positive reactions in the tests of cv. Saturna were due to infection by PVX. PVS caused additional positive $\mathrm{TE}_{1}$ reactions among the 
Table 25. The effect of dilutions of the antisera and additive compounds on the results obtained with the chloroplast agglutination test in the identification of potato viruses $\mathrm{X}, \mathrm{S}, \mathrm{M}$ and $\mathrm{Y}$ in secondarily infected potato leaf sap. $3=$ very strong reaction, $2=$ strong reaction, $1=$ visible reaction, $0=$ no reaction found. The numbers are the means of 10 tests if not otherwise specified.

\begin{tabular}{|c|c|c|c|c|c|c|c|c|c|c|c|c|}
\hline \multirow{3}{*}{$\begin{array}{l}\begin{array}{l}\text { Virus and } \\
\text { cultivar tested }\end{array} \\
\text { PVX }\end{array}$} & \multirow{2}{*}{\multicolumn{3}{|c|}{ Indigenous }} & \multicolumn{6}{|c|}{$\begin{array}{l}\text { Proportional reaction values } \\
\text { Antisera and their dilutions }\end{array}$} & \multirow{2}{*}{\multicolumn{2}{|c|}{ Danish }} & \\
\hline & & & & \multicolumn{3}{|c|}{$\begin{array}{l}\text { Indigenous containing } \\
0.4 \% \text { of } \mathrm{Na}_{2} \mathrm{SO}_{3}\end{array}$} & \multicolumn{3}{|c|}{$\begin{array}{l}\text { Indigenous containing } \\
1 \% \text { of Bentonite }\end{array}$} & & & \\
\hline & $1 / 25$ & $1 / 100$ & $1 / 400$ & $1 / 25$ & $1 / 100$ & $1 / 400$ & $1 / 25$ & $1 / 100$ & $1 / 400$ & $1 / 25$ & $1 / 100$ & $1 / 400$ \\
\hline Ostara & 3.0 & 2.8 & 1.8 & 3.0 & 2.7 & 1.8 & 2.8 & 2.2 & 1.4 & 3.0 & 2.5 & 1.6 \\
\hline Saturna & 3.0 & 2.8 & 1.7 & 3.0 & 2.8 & 1.8 & 2.8 & 2.1 & 1.4 & 2.8 & 2.4 & 1.5 \\
\hline Hja's Tuomas & 3.0 & 2.5 & 1.6 & 3.0 & 2.4 & 1.5 & 2.7 & 2.1 & 1.2 & 2.7 & 2.0 & 1.4 \\
\hline $\begin{array}{l}\text { Mean/\% of } \\
\text { identification } \\
\text { PVS }\end{array}$ & $3.0 / 100$ & $2.7 / 100$ & $1.7 / 100$ & $3.0 / 100$ & $2.6 / 100$ & $1.7 / 100$ & $2.8 / 100$ & $2.1 / 100$ & $1.3 / 100$ & $2.8 / 100$ & $2.3 / 100$ & $1.5 / 100$ \\
\hline Sanna & 2.5 & 2.2 & 1.3 & 2.6 & 1.8 & 1.3 & 2.2 & 1.3 & 1.0 & 2.6 & 1.7 & 1.1 \\
\hline Hja's Tuomas & 2.3 & 1.6 & 0.8 & 2.2 & 1.6 & 0.9 & 1.8 & 1.1 & 0.6 & 2.2 & 1.5 & 0.8 \\
\hline Veto & 2.6 & 2.0 & 1.1 & 2.6 & 1.7 & 0.9 & 2.1 & 1.3 & 0.7 & 2.4 & 2.0 & 1.1 \\
\hline
\end{tabular}

\begin{tabular}{|c|c|c|c|c|c|c|c|c|c|c|c|c|}
\hline $\begin{array}{c}\text { Mean } / \% \text { of } \\
\text { identification } \\
\text { PVM }\end{array}$ & $2.5 / 100$ & $1.9 / 100$ & $1.1 / 90$ & $2.5 / 100$ & $1.7 / 100$ & $1.0 / 87$ & $2.0 / 100$ & $1.2 / 100$ & $0.8 / 77$ & $2.4 / 100$ & $1.7 / 100$ & $1.0 / 90$ \\
\hline Pito & 2.3 & 1.9 & 1.4 & 3.0 & 1.9 & 1.3 & 2.6 & 2.0 & 1.3 & 3.0 & 2.5 & 1.3 \\
\hline Sanna & 3.0 & 2.5 & 1.1 & 2.5 & 2.0 & 1.3 & 2.2 & 1.4 & 1.0 & 2.5 & 2.0 & 1.5 \\
\hline Saturna & 3.0 & 2.7 & 1.6 & 3.0 & 2.5 & 1.5 & 2.7 & 1.8 & 1.2 & 3.0 & 2.5 & 1.5 \\
\hline $\begin{array}{c}\text { Mean } / \% \text { of } \\
\text { identification } \\
\text { PVY }\end{array}$ & $2.8 / 100$ & $2.4 / 100$ & $1.4 / 100$ & $2.8 / 100$ & $2.1 / 100$ & $1.4 / 100$ & $2.5 / 100$ & $1.7 / 100$ & $1.2 / 100$ & $2.8 / 100$ & $2.3 / 100$ & $1.4 / 100$ \\
\hline Ostara & 0.6 & 0.2 & 0.0 & 0.7 & 0.4 & 0.0 & 0.5 & 0.1 & 0.0 & 0.4 & 0.2 & 0.0 \\
\hline Pito & 0.8 & 0.2 & 0.0 & 1.0 & 0.4 & 0.0 & 0.4 & 0.0 & 0.0 & 0.3 & 0.0 & 0.0 \\
\hline Record & 0.8 & 0.3 & 0.0 & 0.7 & 0.3 & 0.0 & 0.4 & 0.2 & 0.0 & 0.9 & 0.4 & 0.0 \\
\hline
\end{tabular}

\section{Mean/\% of}

identification

$\begin{array}{llllll}0.7 / 70 & 0.2 / 30 & 0.0 / 0 & 0.9 / 83 & 0.4 / 37 & 0.0 / 0\end{array}$

$0.4 / 43 \quad 0.1 / 10 \quad 0.0 / 0$

$0.5 / 40 \quad 0.2 / 13 \quad 0.0 / 0$

F values for 1) different viruses $=100.6^{\mathrm{xx}}, \mathrm{LSD}_{0.05}=0.28$

2) different antisera at the same dilutions; PVX $=36.9^{\mathrm{xx}}, \mathrm{LSD}_{0.05}=0.10$

3) different cultivars, PVX $=16.7^{\mathrm{xx}}, \mathrm{LSD}_{0.05}=0.09$

$$
\text { PVS }=43.0^{\mathrm{kxx}}, \mathrm{LSD}_{0.05}=0.11
$$

PVS $=42.1^{\mathrm{xx}}, \mathrm{LSD}_{0.05}=0.09$

$\mathrm{PVM}=3.0$

cvs. Bintje and Record and the same virus also caused additional positive A6 reactions when inoculated with sap from the cvs. Posmo and Hja's Tuomas.

\subsection{Agar gel diffusion methods}

\subsubsection{Double diffusion test}

The double diffusion test can be used to identify the viruses PVX, PVS and PVM when $10 \mu \mathrm{g} / \mathrm{ml}$ of degraded protein of each virus is used. In order to determine this minimum protein concentration, the antiserum was diluted to about its rection end point and was placed in holes c. $2.5 \mathrm{~mm}$ from the 
Table 26. A comparison of the results obtained with comparable A6 and TE , cut leaf tests from field potatoes in 1979 and $1980 .+=$ lesions were detected on the leaves, $-=$ no lesions were detected on the leaves.

\begin{tabular}{|c|c|c|c|c|c|c|c|c|c|c|c|c|}
\hline \multirow[t]{2}{*}{ Cultivar } & \multirow[t]{2}{*}{$\begin{array}{l}\text { Number } \\
\text { of tests }\end{array}$} & \multicolumn{2}{|c|}{$\begin{array}{l}1979 \\
\% \text { infected } \\
\text { leaves }\end{array}$} & \multicolumn{3}{|c|}{$\%$ agreement } & \multirow[t]{2}{*}{$\begin{array}{c}\text { Number } \\
\text { of tests }\end{array}$} & \multicolumn{2}{|c|}{$\begin{array}{c}1980 \\
\% \text { infected } \\
\text { leaves }\end{array}$} & \multicolumn{3}{|c|}{$\%$ agreement } \\
\hline & & & $\mathrm{TE}_{1}$ & $\begin{array}{l}\text { A6+ } \\
\mathrm{TE}_{1}+\end{array}$ & $\begin{array}{r}\mathrm{A} 6+ \\
\mathrm{TE}_{1}-\end{array}$ & $\begin{array}{l}\text { A6- } \\
\mathrm{TE}_{1}+\end{array}$ & & A6 & $\mathrm{TE}_{1}$ & $\begin{array}{l}\mathrm{A} 6+ \\
\mathrm{TE}_{1}+\end{array}$ & $\begin{array}{r}\mathrm{A} 6+ \\
\mathrm{TE}_{1}-\end{array}$ & $\begin{array}{l}\mathrm{A} 6- \\
\mathrm{TE}_{1}+\end{array}$ \\
\hline Bintje & 117 & 37.6 & 72.5 & 24.8 & 12.8 & 48.7 & 100 & 88.0 & 96.0 & 88.0 & 0.0 & 8.0 \\
\hline Jaakko & 103 & 22.3 & 34.0 & 10.7 & 11.6 & 23.3 & 100 & 61.0 & 52.0 & 51.0 & 10.0 & 1.0 \\
\hline Ora & 137 & 11.7 & 9.5 & 6.6 & 5.1 & 2.9 & 100 & 8.0 & 8.0 & 7.0 & 1.0 & 1.0 \\
\hline Ostara & 138 & 8.7 & 5.8 & 5.1 & 3.6 & 0.7 & 100 & 9.0 & 11.0 & 4.0 & 5.0 & 6.0 \\
\hline Pito & 142 & 97.5 & 94.7 & 94.7 & 2.8 & 0.0 & 100 & 98.0 & 92.0 & 92.0 & 6.0 & 0.0 \\
\hline Posmo & 135 & 6.7 & 8.9 & 3.7 & 3.0 & 5.2 & 100 & 47.0 & 30.0 & 30.0 & 17.0 & 0.0 \\
\hline Prevalent & - & - & - & - & - & - & 100 & 37.0 & 27.0 & 23.0 & 14.0 & 4.0 \\
\hline Prumex & 150 & 12.6 & 12.0 & 5.3 & 7.3 & 6.7 & 100 & 37.0 & 27.0 & 18.0 & 19.0 & 8.0 \\
\hline Record & 360 & 15.0 & 33.1 & 13.6 & 1.4 & 19.4 & 100 & 96.0 & 95.0 & 95.0 & 1.0 & 0.0 \\
\hline Sanna & 107 & 88.8 & 87.9 & 81.3 & 7.5 & 6.5 & 100 & 59.0 & 48.0 & 43.0 & 16.0 & 5.0 \\
\hline Saturna & 106 & 96.2 & 78.3 & 78.3 & 17.9 & 0.0 & 100 & 90.0 & 71.0 & 71.0 & 19.0 & 0.0 \\
\hline Sieglinde & - & - & - & - & - & - & 70 & 77.1 & 75.7 & 74.3 & 2.9 & 1.4 \\
\hline Hja’s Timo & 141 & 25.5 & 22.0 & 20.6 & 5.0 & 1.4 & 85 & 69.4 & 41.2 & 41.2 & 28.2 & 0.0 \\
\hline Hja's Tuomas & 150 & 22.0 & 18.7 & 11.3 & 10.7 & 7.3 & 100 & 21.0 & 4.0 & 3.0 & 18.0 & 1.0 \\
\hline Veto & 148 & 8.1 & 0.0 & 0.0 & 8.1 & 0.0 & 100 & 3.0 & 1.0 & 1.0 & 2.0 & 0.0 \\
\hline Average (\%) & & 30.7 & 34.2 & 24.1 & 6.4 & 10.0 & & 52.7 & 44.6 & 42.1 & 10.6 & 2.5 \\
\hline
\end{tabular}

antigen holes in the agar plate. When the distance between the holes was 4 or $5 \mathrm{~mm}$ the lowest effective protein concentrations determined were $20 \mu \mathrm{g} / \mathrm{ml}$ and $40 \mu \mathrm{g} / \mathrm{ml}$ respectively.

In potato leaf sap, viruses could be detected at the following dilutions: PVX $1 / 64$, PVS $1 / 8$ and PVM $1 / 16$. The precipitin lines between the holes obtained from virus infected leaf or tuber sap samples were clearer if the distance between the central hole and the surrounding holes was 4-4.5 mm. The precipitin lines obtained with PVX infected leaf sap samples were the sharpest when the antiserum was diluted to $1 / 16$ (titer 1/128). The chlorophyll present in leaf sap and in the pyrrolidine solution used for virus particle degradation caused some backround reaction in the gels. In some cases this interfered with the readings of the test results (Figs. 72 and 73, page 268.)

PVX could be detected in 1/8 dilutions of sap samples of secondarily infected tubers but PVS or PVM could not be reliably detected in any tuber samples.

\subsubsection{Single diffusion test}

With the single diffusion test, the use of $1 \mu \mathrm{g} / \mathrm{ml}$ of degraded protein of the viruses PVX, PVS and PVM allowed their detection. The sensitivity of the method depended greatly on the antibody concentration in the gel (Table 
Table 27. The lowest relative concentrations of viruses $\mathrm{X}, \mathrm{S}$ and $\mathrm{M}$ detected in diluted pyrrolidine treated potato leaf sap as determined with the single diffusion test.

\begin{tabular}{|c|c|c|c|}
\hline \multirow[t]{2}{*}{$\begin{array}{l}\text { Final antiserum } \\
\text { dilution in the gels }\end{array}$} & \multicolumn{3}{|c|}{$\begin{array}{l}\text { Virus and the greatest dilution of leaf sap } \\
\text { in which the viruses could be detected }\end{array}$} \\
\hline & PVX & PVS & PVM \\
\hline $1 / 10$ & $1 / 64$ & $1 / 32$ & $1 / 32$ \\
\hline $1 / 25$ & $1 / 256$ & $1 / 64$ & $1 / 64$ \\
\hline $1 / 50$ & $1 / 512$ & $1 / 64$ & $1 / 128$ \\
\hline $1 / 100$ & $1 / 512$ & $1 / 32$ & $1 / 64$ \\
\hline
\end{tabular}

27) and the highest sensitivity occurred when the antiserum was diluted to about its reaction end value as determined with the double diffusion test.

The single diffusion test is c. 8 times more sensitive than the double diffusion test. For optimal sensitivity in the single diffusion test a precipitin ring $1-5 \mathrm{~mm}$ wide is necessary (Fig. 75 , page 268). If the virus concentration in the sample is too high compared to the antibody concentration in the agar the antibody molecules are insufficient to stop all diffusing protein fragments which results in a weakly visible, diffuse precipitin ring. In cases of antibody excess, antigen precipitation is minimal or absent altogether. For easily detectable reactions this phenomenon is certainly undesirable.

Potato virus $\mathrm{X}$ was detected in 1/64 diluted tuber sap and viruses $\mathrm{S}$ and $\mathrm{M}$ $1 / 4$ and $1 / 16$ dilutions respectively. Non-specific reactions were abundant when undiluted pyrrolidine treated tuber sap samples were tested. If the sample sap was diluted then less interference occurred.

\subsubsection{Comparisons between the gel diffusion and the agglutination methods}

Exactly the same number of precipitin reactions were obtained when secondarily PVX infected potato leaf samples were tested similarily with the chloroplast agglutination test and both modifications of the gel diffusion test. The chloroplast agglutination test and the single diffusion test gave the same results when PVS and PVM were tested but with the double diffusion test definite reactions only occurred sometimes. The diameter of the precipitin rings varied depending on the virus and the potato cultivar (Table 28).

In the same experiments known concentrations of degraded protein of PVX diffused in the gels to the following distances from the sample hole: 400 $\mu \mathrm{g} / \mathrm{ml} \rightarrow 11 \mathrm{~mm}, 200 \mu \mathrm{g} \rightarrow 7.5 \mathrm{~mm}, 100 \mu \mathrm{g} \rightarrow 5.5 \mathrm{~mm}, 50 \mu \mathrm{g} \rightarrow 4.0 \mathrm{~mm}$ and $25 \mu \mathrm{g} \rightarrow 2.5 \mathrm{~mm}$. According to this comparison the concentration means of the viruses in the test material were as follows: PVX $=250-300 \mu \mathrm{g}, \mathrm{PVS}=$ $40-50 \mu \mathrm{g}$ and PVM $=60-80 \mu \mathrm{g} / \mathrm{ml}$ leaf sap.

The results obtained from normal potato field material tested showed marked variation between the chloroplast agglutination test and the single diffusion test (Table 29). The identification of PVS was the most difficult as both methods gave inaccurate results. The chloroplast agglutination test gave 
Table 28. The movement (in $\mathrm{mm}$ ) of viral protein fragments in single diffusion gels when potato viruses $\mathrm{X}, \mathrm{S}$ and $\mathrm{M}$ were tested in leaf samples with secondary infections. The final concentration of the antisera was $1 / 50$ in $1 \%$ bactoagar gels.

\begin{tabular}{|c|c|c|c|c|c|c|}
\hline \multirow{3}{*}{ Potato cultivar } & \multicolumn{6}{|c|}{ Movement of the protein fragments $(\mathrm{mm})$} \\
\hline & \multicolumn{2}{|c|}{ PVX } & \multicolumn{2}{|c|}{ PVS } & \multicolumn{2}{|c|}{ PVM } \\
\hline & Mean & Variation & Mean & Variation & Mean & Variation \\
\hline Ostara & 5.9 & $3-9$ & & & & \\
\hline Pito & & & & & 3.4 & $2-5$ \\
\hline Sanna & & & 2.5 & $1-4$ & & \\
\hline Saturna & 6.8 & $5-10$ & & & 3.4 & $2-5$ \\
\hline Tuomas & 5.0 & $3-8$ & 2.2 & $1-4$ & 3.9 & $2-5$ \\
\hline Veto & & & 2.7 & $2-4$ & & \\
\hline Mean & 5.9 & & 2.5 & & 3.6 & \\
\hline
\end{tabular}

several incorrect positive reactions and both methods failed to detect low virus concentrations (see comparisons between the chloroplast agglutination test and the ELISA test, section 2.3.5.).

Table 29. Comparison between the chloroplast agglutination test and the single diffusion test. Fifty leaf samples of each cultivar were similarily tested.

$\mathrm{A}=$ the chloroplast agglutination test

$\mathrm{G}_{1}=$ the single diffusion test

$+=$ visible reaction observed

$-=$ no reaction observed

\begin{tabular}{|c|c|c|c|c|c|c|c|c|}
\hline \multirow[b]{2}{*}{ Cultivar } & \multirow[b]{2}{*}{$\begin{array}{l}\text { Virus } \\
\text { PVX }\end{array}$} & \multicolumn{2}{|c|}{$\begin{array}{l}\text { Reactions } \\
\text { observed }\end{array}$} & \multicolumn{3}{|c|}{$\begin{array}{l}\text { Comparison } \\
\text { of the results }\end{array}$} & \multicolumn{2}{|c|}{$\begin{array}{l}\% \text { correct } \\
\text { observations }\end{array}$} \\
\hline & & A & $\mathrm{G}_{1}$ & $\begin{array}{l}\mathrm{A}+ \\
\mathrm{G}_{1}+\end{array}$ & $\begin{array}{l}\mathrm{A}+ \\
\mathrm{G}_{1}-\end{array}$ & $\begin{array}{l}\mathrm{A}- \\
\mathrm{G}_{1}+\end{array}$ & A & $\mathrm{G}_{1}$ \\
\hline Ostara & & 3 & 3 & 3 & 0 & 0 & 100 & 100 \\
\hline Saturna & & 15 & 15 & 15 & 0 & 0 & 100 & 100 \\
\hline Hja's Tuomas & & 6 & 4 & 4 & 2 & 0 & 67 & 100 \\
\hline$\%$ on an average & PVS & 16.0 & 14.7 & 14.7 & 1.3 & 0.0 & 89.0 & 100.0 \\
\hline Ostara & & 33 & 29 & 22 & 11 & 7 & 76 & 93 \\
\hline Saturna & & 12 & 9 & 8 & 4 & 1 & 83 & 89 \\
\hline Hja's Tuomas & & 28 & 31 & 20 & 8 & 11 & 82 & 90 \\
\hline$\%$ on an average & & 48.7 & 46.0 & 33.3 & 15.3 & 12.6 & 80.3 & 90.7 \\
\hline & PVM & & & & & & & \\
\hline Ostara & & 18 & 16 & 15 & 3 & 1 & 83 & 94 \\
\hline Sanna & & 18 & 13 & 13 & 5 & 0 & 72 & 100 \\
\hline Saturna & & 5 & 5 & 5 & 0 & 0 & 100 & 100 \\
\hline$\%$ on an average & & 27.3 & 22.6 & 22.0 & 5.3 & 0.7 & 85.0 & 98.0 \\
\hline
\end{tabular}




\subsection{ELISA method}

\subsubsection{Reaction specificity of different antibody preparates}

For the ELISA method, purified virus-specific immunoglobulin (Ig) and immunoglobulin conjugated with the enzyme alkaline phosphatase (E Ig), prepared as described by CLARK \& ADAMS (1977), was titrated to determine the dilutions suitable for use.

The Ig- and E Ig-reagents for PVX could be readily used for the identification of different diseased plant samples without serious problems. The non-specific reaction to healthy plant sap was low (Table 30) and the differences amongst the replicate absorbance values were insignificant.

All tested combinations where the $\mathrm{E}$ Ig was diluted to $1 / 200$ or $1 / 800$ gave highly specific reactions, the relative specificity values (virus infected test sample absorbance/ healthy test sample absorbance) being higher than 100. A E Ig dilution of $1 / 3200$ contained little of the enzyme but the reaction still remained very specific.

The PVS antisera initially contained too many antibodies against plant proteins to obtain clear virus-specific reactions but after they were removed by host protein absorption no noticeable non-specific reaction to healthy plant sap or to other unrelated viruses occurred. However, marked differences occurred between the ELISA-reagents prepared for PVS isolates (Table $31)$.

The ratio $\left(A_{v} / A_{h}\right)$ of absorbance values obtained from $10^{-1}$ diluted PVS infected and healthy plant sap calculated for each of the preparates showed that the best Ig and E Ig combinations were $1 / 5000$ or $1 / 1000$ dilutions $(0.4-2 \mu \mathrm{g} / \mathrm{ml})$ of $\mathrm{Ig}$ and $1 / 800$ dilution (c. $1.25 \mu \mathrm{g} / \mathrm{ml})$ of E Ig. When the absorbance values obtained were weighted for the function Ig or E Ig (Fig. 70) about the same results could be seen. A coating concentration of Ig higher than $2 \mu \mathrm{g} / \mathrm{ml}$ gave decreasing specificity values if a normal coating incubation time of $2 \mathrm{~h}$ at $37 \mathrm{C}$ was used.

The antibody preparates for PVM identification with the ELISA test, made from antisera for PVM isolates MSF1 and MSF8, had a highly virusspecific function without any noticeable reaction to plant proteins. The preparates for PVM isolate MSF8 were somewhat related to potato virus S (Table 32).

With the PVY antibody preparates for the ELISA test there was initially serious problems with non-specific reactions due to plant proteins. The sap samples of PVY infected Nicotiana glutinosa diluted to $10^{-3}$, however, always gave higher absorbance values than healthy sap of the same species diluted to $10^{-1}$. No noticeable reaction to potato virus X occurred (Table 33). 
Table 30. The absorbance values obtained for PVXSF2 specific immunoglobulin (Ig) and its conjugate (E Ig) when titrated with homologous PVX infected diluted Nicotiana glutinosa sap.

$\operatorname{Ig} 1 / 1000=2 \mu \mathrm{g} / \mathrm{ml}$, E Ig dilutions: $\mathrm{a}=1 / 200, \mathrm{~b}=1 / 800, \mathrm{c}=1 / 3200$; substrate incubation 30 $\min$ at $22 \mathrm{C}$.

Test sample

Absorbance values at $405 \mathrm{~nm}$

Ig dilution

$1 / 1000 \quad 1 / 5000$

\begin{tabular}{rrrrrrrrrrrr}
\hline PVX, N. glutinosa & $10^{-1}$ & 1.706 & .830 & .352 & 1.980 & .850 & .390 & 1.930 & .836 & .216 \\
& $n$ & $10^{-2}$ & 1.490 & .616 & .221 & 1.628 & .690 & .200 & 1.271 & .510 & .118 \\
& $n$ & $10^{-3}$ & .790 & .218 & .080 & .840 & .230 & .076 & .620 & .158 & .080 \\
PVY & $\cdots$ & $10^{-1}$ & .005 & .002 & .002 & .003 & .002 & .001 & .003 & .001 & .002 \\
healthy & $10^{-1}$ & .005 & .002 & .002 & .002 & .002 & .001 & .003 & .001 & .001 \\
\hline E Ig dilution & & \multirow{2}{*}{$\mathrm{a}$} & $\mathrm{b}$ & $\mathrm{c}$ & $\mathrm{a}$ & $\mathrm{b}$ & $\mathrm{c}$ & $\mathrm{a}$ & $\mathrm{b}$ & $\mathrm{c}$ \\
\hline
\end{tabular}

Table 31. Absorbance values obtained for homologous reactions of PVS antibody reagents (I $=\mathrm{SSF} 4$, II $=\mathrm{SSF} 1, \mathrm{III}=\mathrm{SSF} 14)$ in the ELISA test. For titration diluted healthy and infected sap of Nicotiana debneyi was used. $\operatorname{Ig} 1 / 1000=2 \mu \mathrm{g} / \mathrm{ml}$, E Ig $1 / 200=\mathrm{a}, 1 / 800=\mathrm{b}, 1 / 3200=\mathrm{c}$. Substrate incubation was carried out for $40 \mathrm{~min}$ at $22 \mathrm{C} . \mathrm{A}_{\mathrm{v}} / \mathrm{A}_{\mathrm{h}}$ represents the ratio of absorbance values obtained for PVS infected and healthy samples at a dilution of $10^{-1}$.

\begin{tabular}{|c|c|c|c|c|c|c|c|c|c|c|}
\hline \multirow{3}{*}{$\begin{array}{l}\text { Sample } \\
\text { I } \\
\text { PVS, N. debneyi }\end{array}$} & \multirow[b]{3}{*}{$10^{-1}$} & \multicolumn{9}{|c|}{$\begin{array}{l}\text { Absorbance values at } 405 \mathrm{~nm} \\
\text { Ig dilutions }\end{array}$} \\
\hline & & \multicolumn{3}{|c|}{$1 / 200$} & \multicolumn{3}{|c|}{$1 / 1000$} & \multicolumn{3}{|c|}{$1 / 5000$} \\
\hline & & 1.421 & .680 & .242 & 1.192 & .608 & .209 & 1.004 & .555 & .191 \\
\hline & $10^{-2}$ & .837 & .391 & .175 & .726 & .359 & .136 & .714 & .357 & .117 \\
\hline$”$ & $10^{-3}$ & .315 & .192 & .074 & .274 & .152 & .075 & .238 & .139 & .086 \\
\hline PVX & $10^{-1}$ & .075 & .023 & .019 & .047 & .025 & .015 & .022 & .019 & .019 \\
\hline healthy " & $10^{-1}$ & .053 & .025 & .021 & .034 & .025 & .019 & .028 & .021 & .019 \\
\hline $\mathrm{A}_{\mathrm{v}} / \mathrm{A}_{\mathrm{h}}$ & & 26.8 & 27.2 & 9.3 & 35.1 & 24.3 & 11.0 & 35.8 & 26.4 & 8.0 \\
\hline PVS, $N$. debneyi & $10^{-1}$ & 1.876 & 1.363 & 1.213 & 1.855 & 1.698 & 1.254 & 1.793 & 1.483 & 1.177 \\
\hline , & $10^{-2}$ & .621 & .530 & .441 & .595 & .542 & .480 & -.539 & .529 & .482 \\
\hline$n$ & $10^{-3}$ & .179 & .132 & .083 & .162 & .123 & .087 & .115 & .099 & .087 \\
\hline PVX & $10^{-1}$ & .031 & .022 & .024 & .016 & .024 & .019 & .019 & .021 & .015 \\
\hline healthy " & $10^{-1}$ & .033 & .023 & .021 & .023 & .018 & .016 & .024 & .020 & .016 \\
\hline $\mathrm{A}_{\mathrm{v}} / \mathrm{A}_{\mathrm{h}}$ & & 56.9 & 59.3 & 57.8 & 80.7 & 94.3 & 78.4 & 74.7 & 74.1 & 73.6 \\
\hline PVS, $N$. debneyi & $10^{-1}$ & 1.401 & 1.130 & .696 & 1.397 & .930 & .619 & 1.230 & .880 & .389 \\
\hline " & $10^{-2}$ & 1.188 & .610 & .560 & 1.042 & .734 & .470 & .830 & .400 & .153 \\
\hline$"$ & $10^{-3}$ & .720 & .320 & .130 & .340 & .310 & .100 & .370 & .134 & .113 \\
\hline PVX & $10^{-1}$ & .105 & .049 & .033 & .093 & .039 & .037 & .060 & .039 & .015 \\
\hline healthy & $10^{-1}$ & .095 & .039 & .027 & .075 & .024 & .018 & .052 & .021 & .016 \\
\hline $\mathrm{A}_{\mathrm{v}} / \mathrm{A}_{\mathrm{h}}$ & & 14.7 & 29.0 & 25.8 & 18.6 & 38.8 & 33.8 & 23.6 & 41.9 & 24.3 \\
\hline E Ig dilution & & a & b & c & a & b & c & a & b & c \\
\hline
\end{tabular}




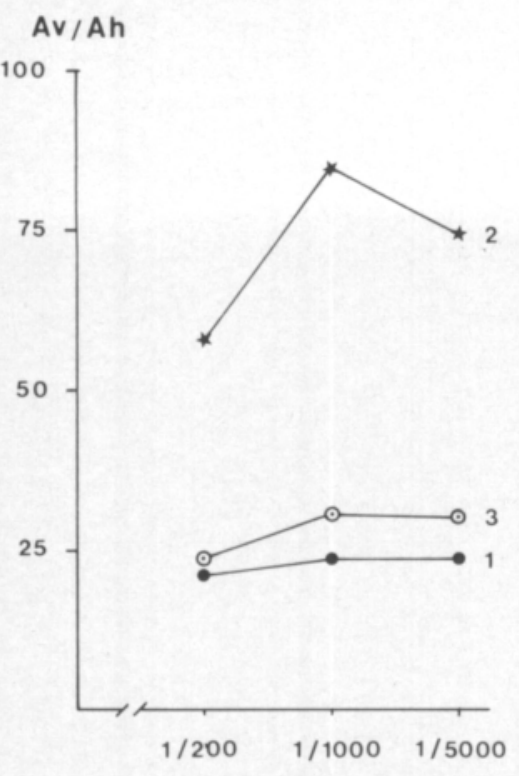

a. Ig-dilution

\section{Av / Ah}

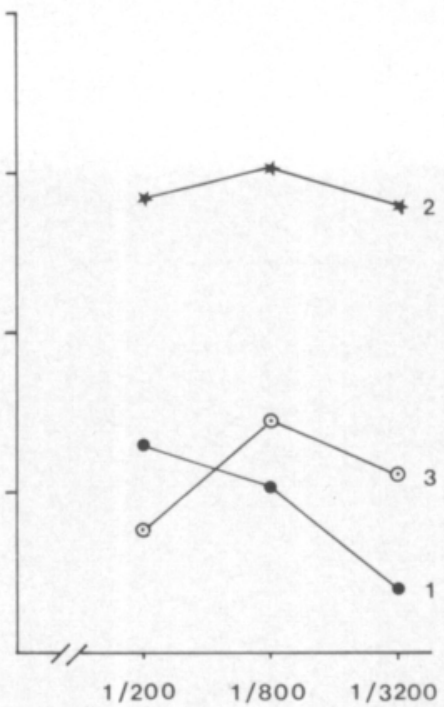

b. Elg-dilution
Fig. 70. The ratio of PVS-absorbance values of virus infected and healthy leaf sap diluted $10^{-1}$ and calculated separately for each antiserum preparate and weighted according to the function Ig (a) or E Ig (g) $1=$ isolate SSF 4 2 = isolate SSF1 $3=$ isolate SSF14

Table 32. Absorbance values obtained for homologous reactions of PVM antibody preparates ( $\mathrm{I}=\mathrm{MSF}$, II = MSF8) in the ELISA test. For titration diluted healthy and infected sap of tomato (Lycopersicon esculentum) was used. Ig $1 / 1000=2 \mu \mathrm{g} / \mathrm{ml}, \mathrm{E} \mathrm{Ig} 1 / 200=\mathrm{a}, 1 / 800=\mathrm{b}, 1 / 3200=$ c. Substrate incubation was carried out for $30 \mathrm{~min}$ at $22 \mathrm{C} . \mathrm{A}_{\mathrm{v}} / \mathrm{A}_{\mathrm{h}}$ presents the ratio of absorbance values obtained for PVM infected and healthy samples at a dilution of $10^{-1}$.

Test sample

I

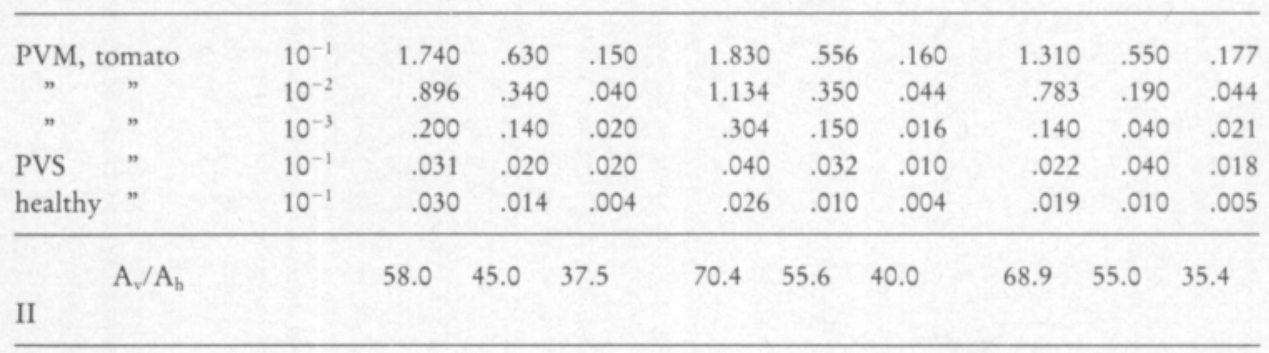

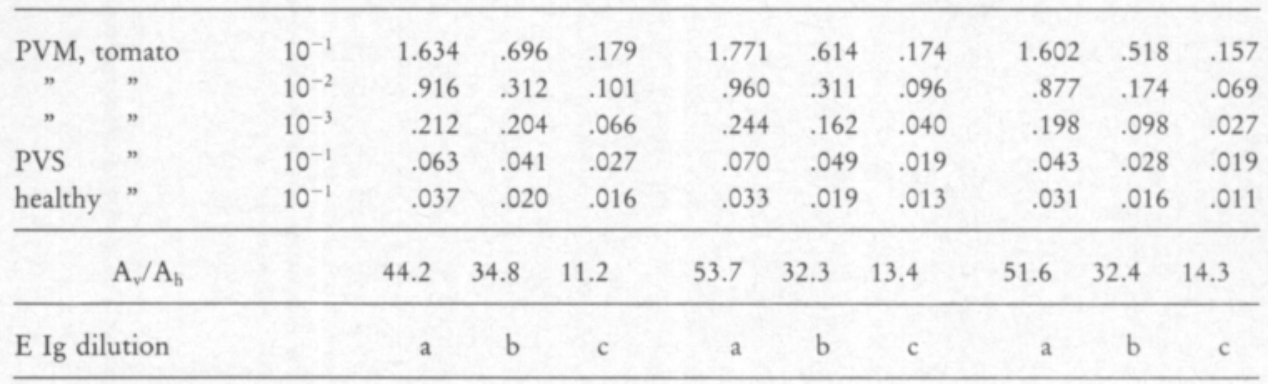


Table 33. Absorbance values obtained for homologous reactions of PVY antibody preparates ( $I=$ YSF4, $\mathrm{II}=\mathrm{YSF} 11, \mathrm{III}=\mathrm{YSF} 10)$ in the ELISA test. For titration diluted healthy and infected sap of Nicotiana glutinosa was used. $\operatorname{Ig} 1 / 1000=2 \mu \mathrm{g} / \mathrm{ml}$, E Ig $1 / 200=\mathrm{a}, 1 / 800=\mathrm{b}, 1 / 3200=\mathrm{c}$. Substrate incubation was carried out for $1 \mathrm{~h}$ at $22 \mathrm{C}$. $\mathrm{A}_{\mathrm{v}} / \mathrm{A}_{\mathrm{h}}$ represents the ratio of absorbance values obtained for PVY infected and healthy samples at a dilution of $10^{-1}$.

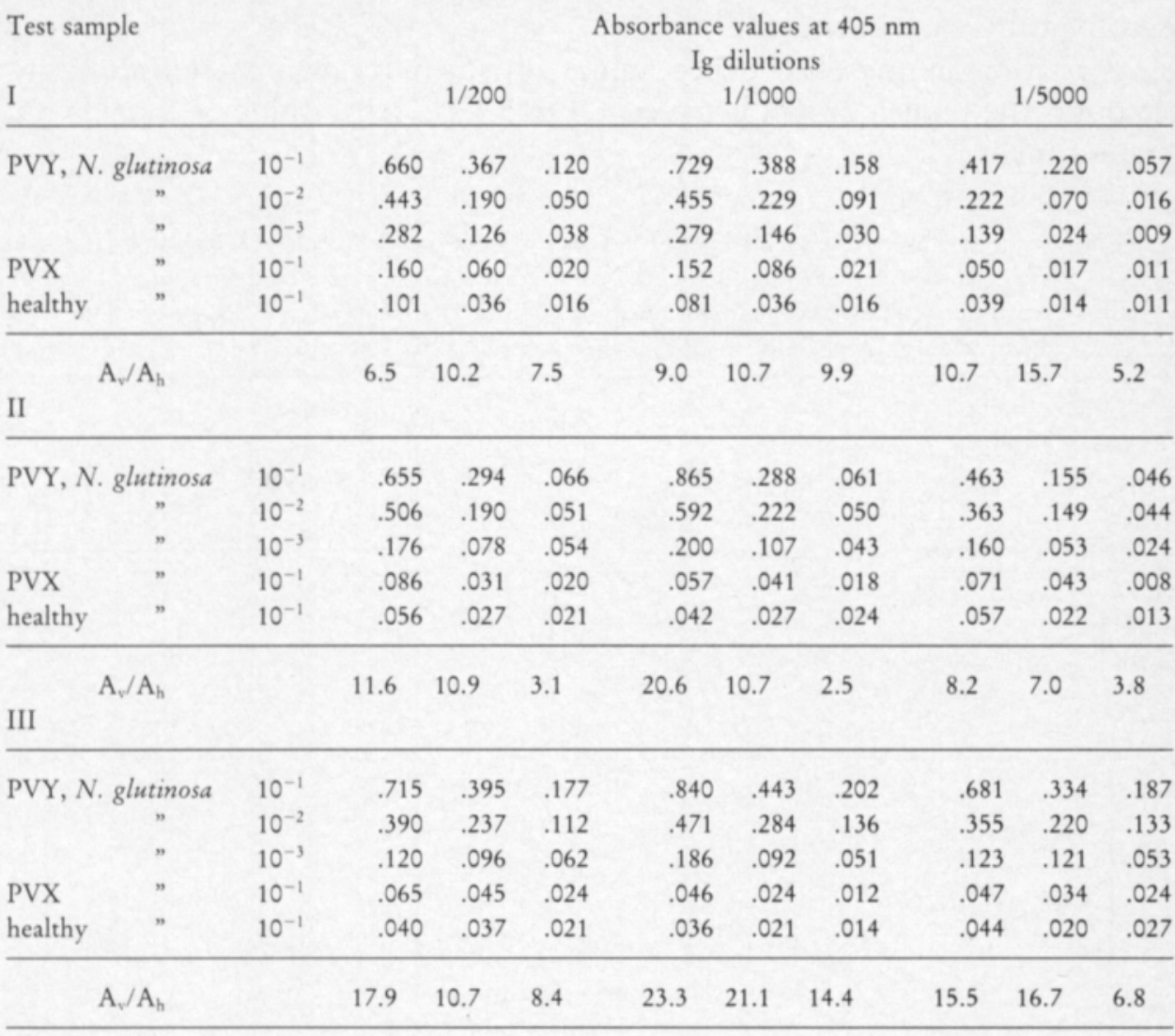

$\begin{array}{llllllllllll}\text { E Ig dilution } & \text { a } & \text { b } & c & \text { a } & \text { b } & \text { c } & \text { a } & \text { b } & \text { c }\end{array}$




\subsubsection{Test sensitivity}

Potato viruses could be identified in purified virus suspensions of low concentration without any specificity problems. PVX was reliably identified at a concentration of $10^{-7} \mathrm{mg} / \mathrm{ml}$ (Table 34). All purified isolates tested were serologically closely related.

Variation in the absorbance values obtained for comparable dilutions amongst the replicates was between 1.4 to $5.6 \%$. An $\mathrm{F}$ value of 1.269 is not significant.

Table 34. The mean absorbance values from ELISA tests of 4 purified PVX isolates. The plate coating and conjugate dilution was $1 \mu \mathrm{g} \mathrm{Ig} / \mathrm{ml}$. A $10^{\circ}$ dilution is equal to a virus concentration of $1 \mathrm{mg} / \mathrm{ml}$. Substrate incubation was carried out for $40 \mathrm{~min}$ at $22 \mathrm{C}$ and 3 replications were done. The absorbance values obtained for PBS-Tween controls were $0.000 \pm 0.002$.

\begin{tabular}{lccccccccccc}
\hline & \multicolumn{10}{c}{$\begin{array}{c}\text { Absorbance values at } 405 \mathrm{~nm} \\
\text { Sample dilutions }\end{array}$} \\
$\begin{array}{l}\text { Virus } \\
\text { isolate }\end{array}$ & $10^{\circ}$ & $10^{-1}$ & $10^{-2}$ & $10^{-3}$ & $10^{-4}$ & $10^{-5}$ & $10^{-6}$ & $10^{-7}$ & $10^{-8}$ & $10^{-9}$ \\
\hline XSF6 & $>2$ & $>2$ & $>2$ & $>2$ & $>2$ & .857 & .224 & .126 & .063 & .029 \\
XSF13 & $>2$ & $>2$ & $>2$ & $>2$ & 1.641 & .630 & .209 & .112 & .044 & .019 \\
XSF14 & $>2$ & $>2$ & $>2$ & $>2$ & 1.776 & .706 & .198 & .113 & .066 & .024 \\
XSF2 $_{\text {PVY }}$ (YSF11) & $>2$ & $>2$ & $>2$ & $>2$ & $>2$ & 1.041 & .316 & .171 & .092 & .033 \\
& .063 & .042 & .028 & .019 & .014 & .015 & .011 & .009 & .008 & .006 \\
\hline
\end{tabular}

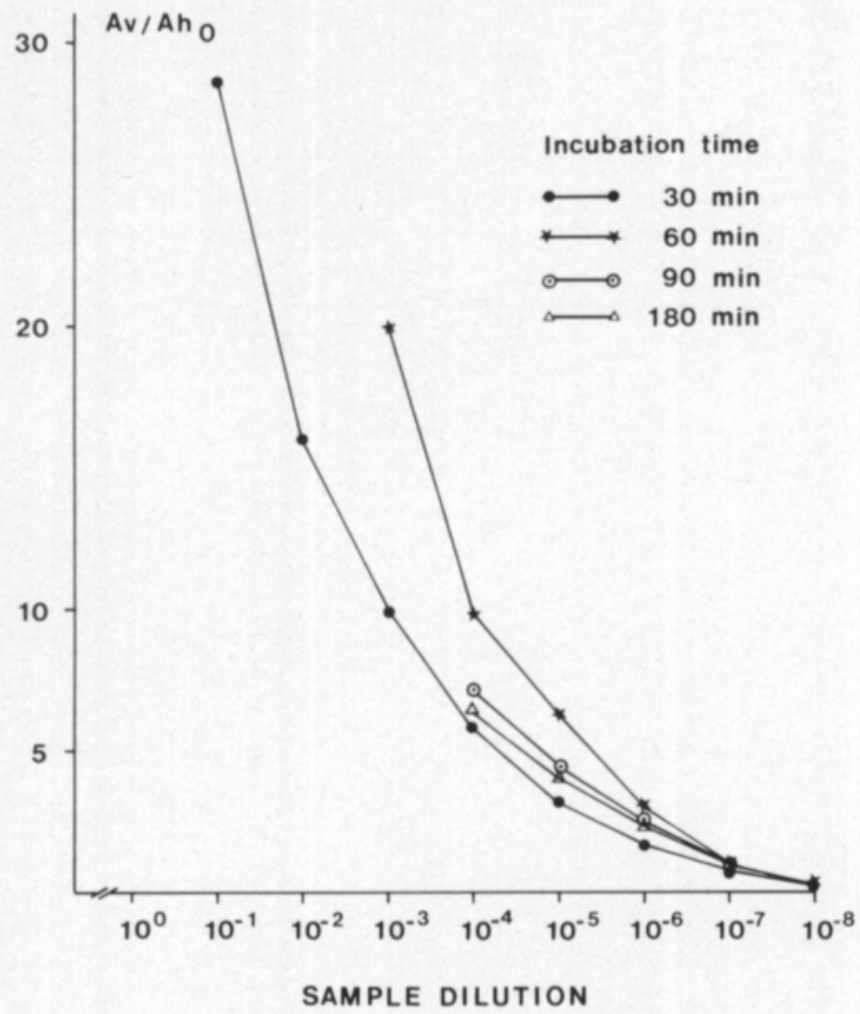

Fig. 77. The effect of substrate incubation time on the specificity of the reaction. Ratio $\mathrm{A}_{1} / \mathrm{A}_{\text {ho }}=$ the absorbance value of (diluted) virus infected sample / the absorbance mean value of undiluted healthy samples. The virus is PVM in tomato leaf sap. 
Substrate incubation time was not very critical if the immunoglobulin and conjugate reaction was virus-specific. If the reaction was highly virus-specific an incubation time of c. 30-180 min gave similar specific absorbtion values (Fig. 77). The higher reaction specificity obtained the longer incubation time could be used. An incubation time of $1 \mathrm{~h}$ at $22 \mathrm{C}$ was normally satisfactory but in several cases the color reaction was too intense for the plate reader and so shorter incubation times were necessary.

\subsubsection{Relationships between the viruses and the virus isolates as determined with the ELISA test}

The PVX antibody preparates did not noticeably react with potato viruses S, M (Table 37) or Y (Table 34). The serological variability of the PVX isolates as tested with the ELISA test was insignificant, however the homologous reaction was the strongest (Table 34).

The PVS reagents were weakly serologically related to the PVM isolates, and similarily the PVM reagents were somewhat related to the PVS isolates, but no serological relationship to virus $\mathrm{X}$ was detected by either of these reagents (Tables 35 and 37 ).

The antibody preparates of PVS SSF1 and SSF4 reacted similarly against a selected isolate from the group, isolate SSF6, but the preparates of isolate SSF14 were distantly related to the same isolate (SSF6).

The antibody preparates made for PVM were similarly serologically closely related to a given PVM antigen but some differences in their relationship to PVS isolates were found.

Marked serological variation between the PVY isolates was detected with the ELISA test. When diluted leaf sap samples of potato and $N$. glutinosa sap infected with $\mathrm{PVY}^{\circ}$ and $\mathrm{PVY}^{\mathrm{n}}$ strain isolates were simultaneously tested with the antibody preparates produced against each virus strain the strain-specific homologous reaction was always significantly stronger than the non-strain-

Table 35. Serological relationships between potato viruses $\mathrm{S}$ and $\mathrm{M}$ as detected in cross reaction tests done with the ELISA method. Immunoglobulins $(\mathrm{Ig})$ at a concentration of $1 \mu \mathrm{g} / \mathrm{ml}$ and enzyme conjugates (E Ig) at a concentration of $2.5 \mu \mathrm{g} / \mathrm{ml}$ were used. Three replicates were done and substrate incubation was carried out for $40 \mathrm{~min}$ at $22 \mathrm{C}$.

\begin{tabular}{|c|c|c|c|c|c|c|}
\hline \multirow{3}{*}{$\begin{array}{l}\text { Test sample } \\
\text { and its dilution }\end{array}$} & & \multicolumn{5}{|c|}{ Absorbance at $405 \mathrm{~nm}$} \\
\hline & & \multicolumn{3}{|c|}{ PVS-Ig + E Ig } & \multicolumn{2}{|c|}{ PVM-Ig +E Ig } \\
\hline & & SSF1 & SSF4 & SSF14 & MSF1 & MSF8 \\
\hline PVM, tomato & $10^{-1}$ & .066 & .057 & .089 & 1.771 & 1.804 \\
\hline & $10^{-2}$ & .030 & .036 & .055 & .884 & 1.006 \\
\hline " potato & $10^{-1}$ & .057 & .066 & .087 & 1.691 & 1.470 \\
\hline Healthy tomato & $10^{-1}$ & .047 & .017 & .077 & .027 & .031 \\
\hline PVS, tomato & $10^{-1}$ & 1.331 & 1.762 & .960 & .049 & .067 \\
\hline " $\quad "$ & $10^{-2}$ & .566 & .795 & .431 & .025 & .036 \\
\hline$"$ potato & $10^{-1}$ & .976 & 1.496 & .568 & .041 & .072 \\
\hline Healthy potato & $10^{-1}$ & .061 & .034 & .081 & .031 & .036 \\
\hline
\end{tabular}


specific (heterologous) reaction. Strain specific samples of antigen preparates diluted ten times gave higher absorbance values than ten times less diluted non-strainspecific samples (eg. the absorbance values for $\mathrm{PVY}^{\circ}$ samples diluted to $10^{-2}$, were higher than for $10^{-1}$ diluted $\mathrm{PVY}^{\mathrm{n}}$ samples and vice versa) (Figs. 71 and 76).

Variation in the absorbance values could be decreased with the use of mixed (1:1) serum preparates of both virus strains (Table 36). The nonspecific reaction to plant protein remained low even in these cases.

\section{$\mathrm{PVY}^{\circ}$ - absorbance}

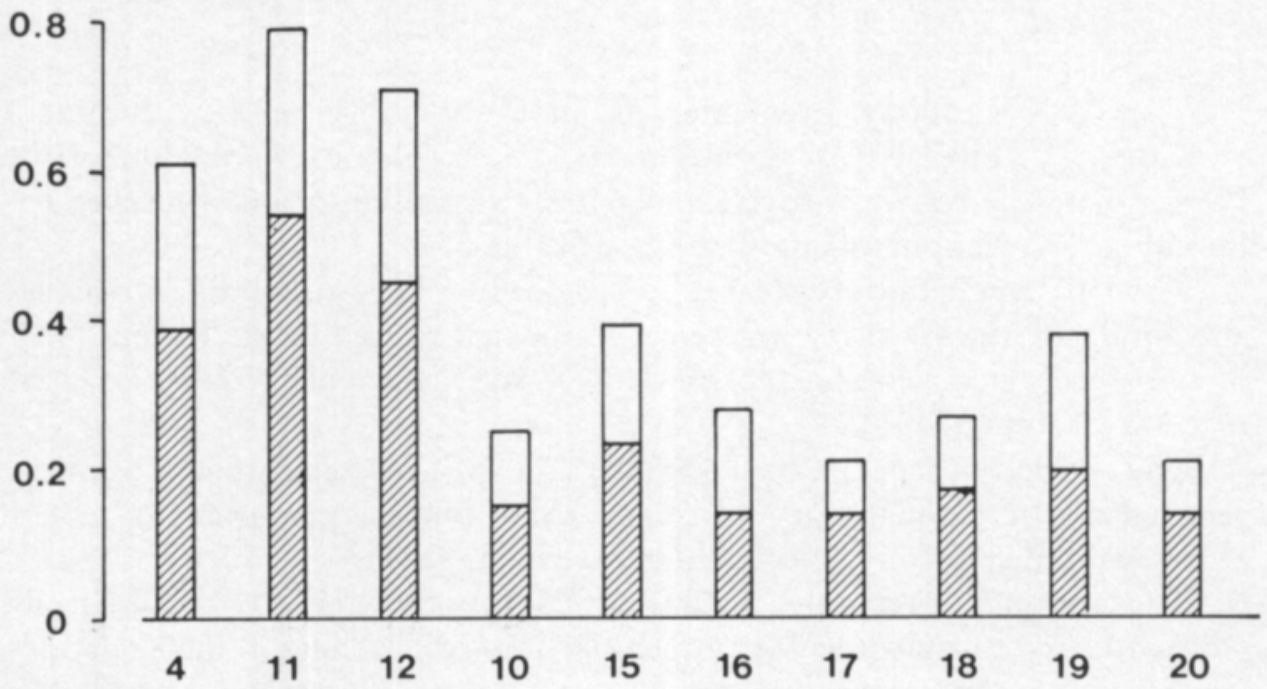

PVY ${ }^{n}$ - absorbance

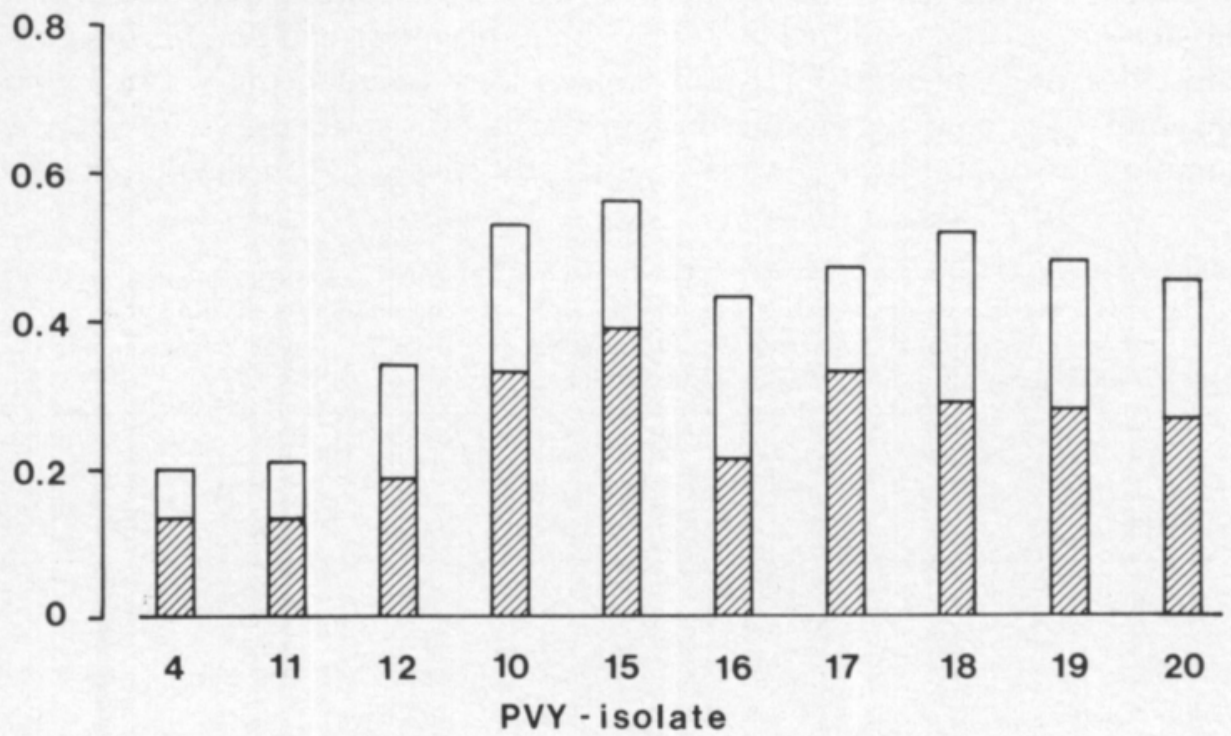

Fig. 71. The mean absorbance values obtained from the samples of $N$. glutinosa infected with different PVY-isolates using antiserum preparates for PVY ${ }^{\circ}$ and PVY ${ }^{\mathrm{n}} . \mathrm{Ig}=1 \mu \mathrm{g} / \mathrm{ml}, \mathrm{E} \mathrm{Ig} 2.5 \mu \mathrm{g} / \mathrm{ml}$. The substrate was incubated for $1 \mathrm{~h}$ at $22 \mathrm{C}$ and 3 replications were done. The bar represents a $10^{-1}$ diluted sample and the darkened part a $10^{-2}$ diluted sample. 
Most of the PVY isolates could be typically included in the strains $\mathrm{Y}^{\circ}$ or $\mathrm{Y}^{\mathrm{n}}$ but some isolates, such as YSF15 and YSF19, have the properties of both strains (Fig. 71).

Potato viruses $\mathrm{X}, \mathrm{S}$ and $\mathrm{M}$ could be individually identified in virus mixtures without any specificity problems or noticeable loss of sensitivity when the ELISA test was used. All of the viruses could be reliably identified in mixtures of systemically infected test plant leaf sap diluted to $1 / 300$ Table 37, Fig. 74).

Table 36. Mean absorbance values obtained from primarily infected potato leaf samples with the ELISA test. The serum preparates were as follows: $1=\mathrm{Y}^{\circ}, 2=\mathrm{Y}^{\mathrm{n}}, 3=\mathrm{Y}^{\circ+\mathrm{n}}$. The concentration of the immunoglobulins (Ig) was $1 \mu \mathrm{g} / \mathrm{ml}$ and that of the conjugates (E Ig) c. $2.5 \mu \mathrm{g} / \mathrm{ml}$. Substrate incubation was carried out for $1 \mathrm{~h}$ at $20 \mathrm{C}$ and three replicates were done.

Serum preparates

and samples tested

(1)

\begin{tabular}{ll}
\hline Virus infected sap & $10^{-1}$ \\
& $10^{-2}$ \\
& $10^{-3}$ \\
Healthy sap & $10^{-1}$ \\
&
\end{tabular}

$\begin{array}{ll}\text { Virus infected sap } & 10^{-1} \\ & 10^{-2} \\ & 10^{-3} \\ \text { Healthy sap } & 10^{-1} \\ (3) & \end{array}$

\begin{tabular}{ccccccc}
\hline Virus infected sap & $10^{-1}$ & .311 & .418 & .371 & .317 & .521 \\
$n$ & $10^{-2}$ & .119 & .211 & .162 & .151 & .217 \\
& $10^{-3}$ & .067 & .091 & .082 & .070 & .097 \\
Healthy sap & $10^{-1}$ & .041 & .037 & .035 & .041 & .026 \\
\hline
\end{tabular}

Table 37. Absorbance values obtained for potato viruses $\mathrm{X}, \mathrm{S}$ and $\mathrm{M}$ tested individually or as a mixture in diluted plant sap using specific antibodies for each virus or antibody mixtures. Plate coating and conjugate dilution was $1 \mu \mathrm{g} \mathrm{Ig} / \mathrm{ml}$ and the substrate incubation time was $40 \mathrm{~min}$ at $22 \mathrm{C}$.

Test sample and its dilution
Antibody preparates and the mean absorbance values at $405 \mathrm{~nm}$

\begin{tabular}{llrrrr} 
& & PVX & PVS & PVM & Mixture \\
\hline PVX $N$. glutinosa & $1 / 10$ & 1.792 & .023 & .020 & 1.932 \\
PVS $N$. debneyi & $1 / 10$ & .006 & 1.536 & .026 & 1.546 \\
PVM $L$. esculentum & $1 / 10$ & .005 & .027 & 1.496 & 1.318 \\
Virus mixture & $1 / 30$ & 1.611 & 1.209 & 1.209 & 1.930 \\
$\quad 0$ & $1 / 300$ & 1.135 & .464 & .794 & 1.529 \\
Healthy plant sap & $1 / 30$ & .015 & .015 & .009 & .013 \\
mixture & & & & & \\
\hline
\end{tabular}

Absorbance at $405 \mathrm{~nm}$ for

PVY isolates tested

$\begin{array}{lllll}\text { YSF4 } & \text { YSF10 } & \text { YSF11 } & \text { YSF12 } & \text { YSF15 }\end{array}$

$\begin{array}{llllll}0^{-1} & .449 & .177 & .511 & .420 & .299 \\ 0^{-2} & .288 & .128 & .297 & .202 & .183 \\ 0^{-3} & .137 & .063 & .172 & .115 & .077 \\ 0^{-1} & .048 & .033 & .047 & .031 & .037\end{array}$

$\begin{array}{lllll}.108 & .380 & .096 & .169 & .289\end{array}$

$\begin{array}{llllll}0^{-3} & .095 & .149 & .066 & .106 & .109 \\ 0^{-1} & .035 & .060 & .037 & .041 & .029\end{array}$

$\begin{array}{llllll}0^{-3} & .095 & .149 & .066 & .106 & .109 \\ 0^{-1} & .035 & .060 & .037 & .041 & .029\end{array}$


Fig. 72

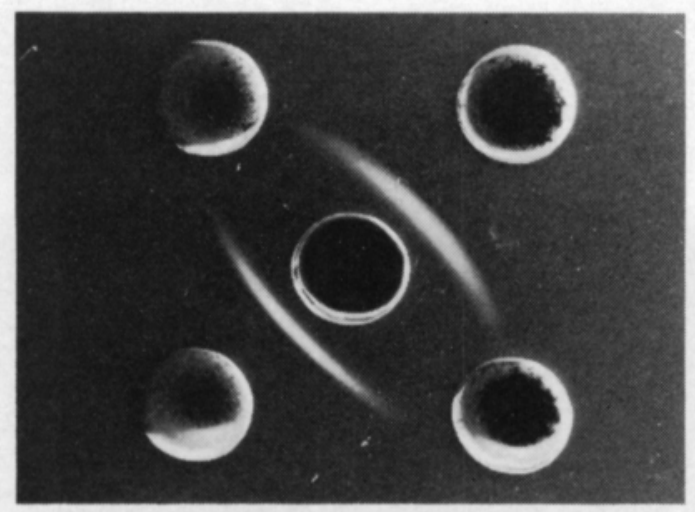

Fig. 73
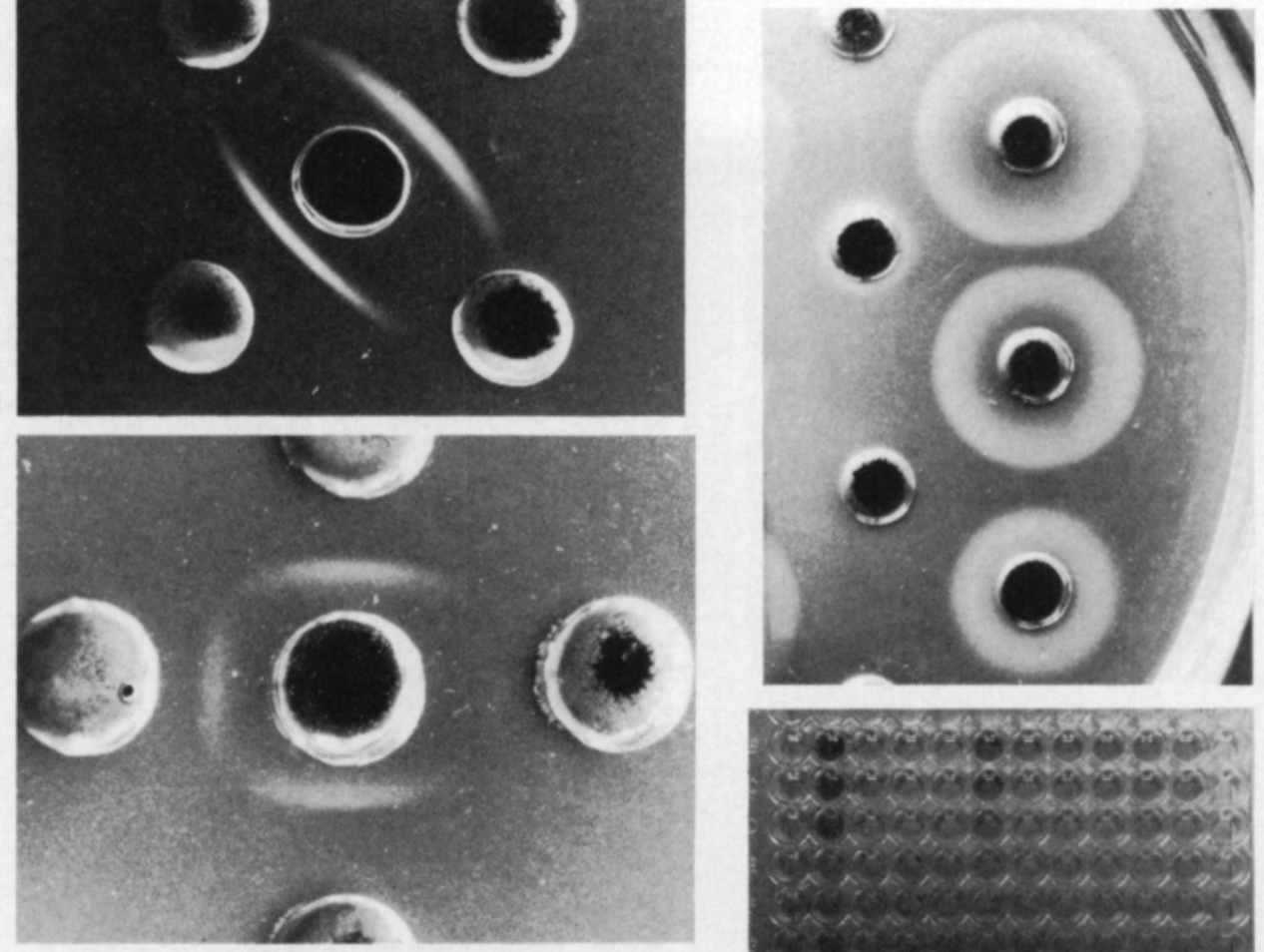

Fig. 75

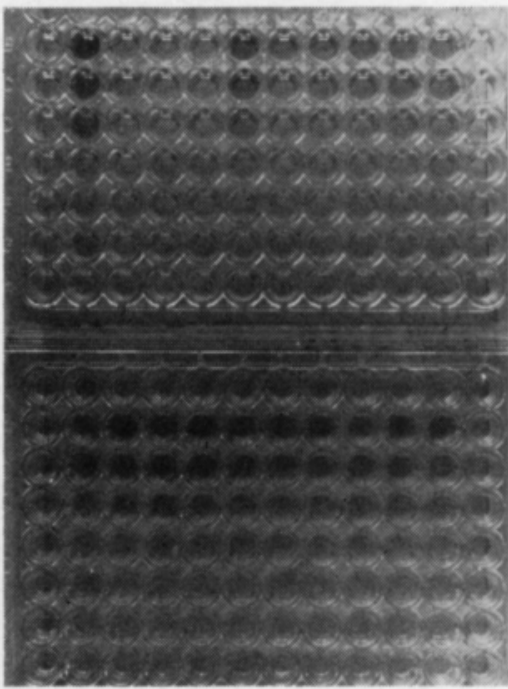

Fig. 76

Fig. 74

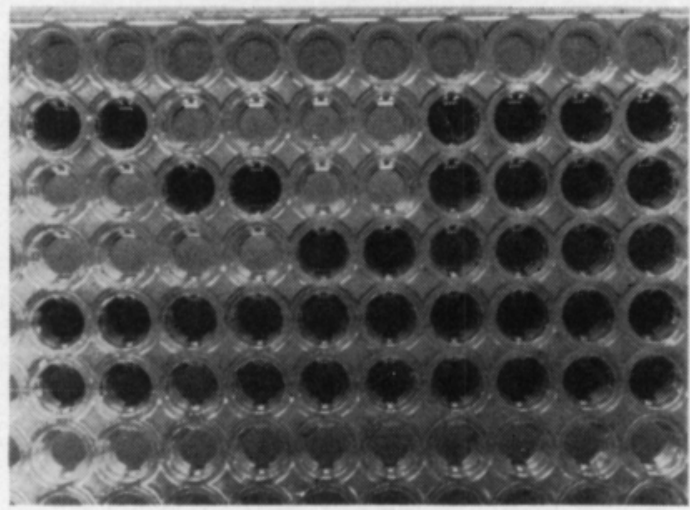

Figs. 72 and 73. Double diffusion tests in agar gel. The sharp precipitin line indicates a specific reaction of optimal concentrations of antibodies and antigens (Fig. 72, lower precipitin line). During the course of the immunization program the antiserum loses its specificity and the precipitin lines are broader and diffuse (Fig. 73).

Fig. 74. The identification of potato viruses $\mathrm{X}, \mathrm{S}$ and $\mathrm{M}$ individually or as a mixture using specific antibodies for each virus (vertical rows 1, $2=$ PVX; 3, $4=$ PVS; 5, $6=$ PVM) or antibody mixtures (vertical rows 7-10). Horizontal rows: $1=$ PBS-Tween, $2=$ PVX $10^{-1}$ diluted sap, 3 $=\operatorname{PVS} 10^{-1}$ diluted sap, $4=$ PVM $10^{-1}$ diluted sap, $5=1 / 30$ mixture, $6=1 / 300$ mixture, $7=$ PVY $10^{-1}$ diluted sap. Plate coating and conjugate dilution was $1 \mu \mathrm{g} / \mathrm{Ig} / \mathrm{ml}$ and the substrate incubation time was $40 \mathrm{~min}$ at $22 \mathrm{C}$.

Fig. 75. Serial dilutions of PVX-D antigen in a single diffusion test.

Fig. 76. ELISA test of different PVY isolates. The same samples and the same dilutions are seen in both plates. Antiserum reagents for $\mathrm{PVY}^{\circ}$ were used in the upper plate and reagents for $\mathrm{PVY}^{\mathrm{n}}$ were used in the lower plate. 


\subsubsection{Identification of known isolates of PVX, PVM, PVS and PVY with indigenous test reagents}

Potato viruses $\mathrm{X}$ and $\mathrm{M}$ could be equally reliably identified in comparable tuber and leaf samples because of their relatively high concentrations in the

Table 38. The mean absorbance values obtained from comparable tests of secondarily infected potato tuber and leaf samples for PVX with the ELISA test. The plate coating and conjugate dilution was $1 \mu \mathrm{g} \mathrm{Ig} / \mathrm{ml}$ and substrate incubation was carried out for $40 \mathrm{~min}$ at $22 \mathrm{C}$. Ten virus infected (V) and ten healthy $(\mathrm{H})$ comparable samples at the same developmental stage were tested and three replicates were done.

\begin{tabular}{|c|c|c|c|c|c|c|c|c|c|c|}
\hline \multirow[b]{2}{*}{ Test sample } & & \multicolumn{9}{|c|}{ Sample dilution and absorbance values at $405 \mathrm{~nm}$} \\
\hline & & $10^{\circ}$ & $10^{-1}$ & $10^{-2}$ & $10^{-3}$ & $10^{-4}$ & $10^{-5}$ & $10^{-6}$ & $10^{-7}$ & $10^{-8}$ \\
\hline Dormant tubers & V & $>2$ & 1.538 & .838 & .277 & .124 & .068 & .034 & .024 & .015 \\
\hline 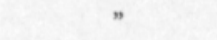 & $\mathrm{H}$ & .076 & .064 & .041 & .034 & .027 & .022 & .014 & .011 & .010 \\
\hline Sprouted tubers & V & $>2$ & $>2$ & 1.303 & .645 & .326 & .128 & .064 & .036 & .022 \\
\hline 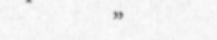 & $\mathrm{H}$ & .046 & .031 & .022 & .016 & .009 & .007 & .005 & .005 & .007 \\
\hline Leaf samples & V & $>2$ & $>2$ & $>2$ & .977 & .404 & .198 & .100 & .060 & .027 \\
\hline$n$ & $\mathrm{H}$ & .063 & .044 & .036 & .024 & .020 & .024 & .023 & .016 & .014 \\
\hline
\end{tabular}

Fig. 78. The ratio $\left(A_{x} / A_{\text {ho }}\right)$ of absorbance values obtained from diluted, infected sap and undiluted, healthy potato sap. The diseased samples were from potatoes secondarily infected with PVX and the samples were taken at different developmental stages.

- $\bullet$ = dormant tuber

$\star \star \star \quad=$ sprouted tuber

$\circ \circ \circ=$ leaf sample

Substrate incubation was carried out for $40 \mathrm{~min}$ at 22 C.

\section{$\mathrm{Ax} / \mathrm{Ah}_{\mathrm{O}}$}

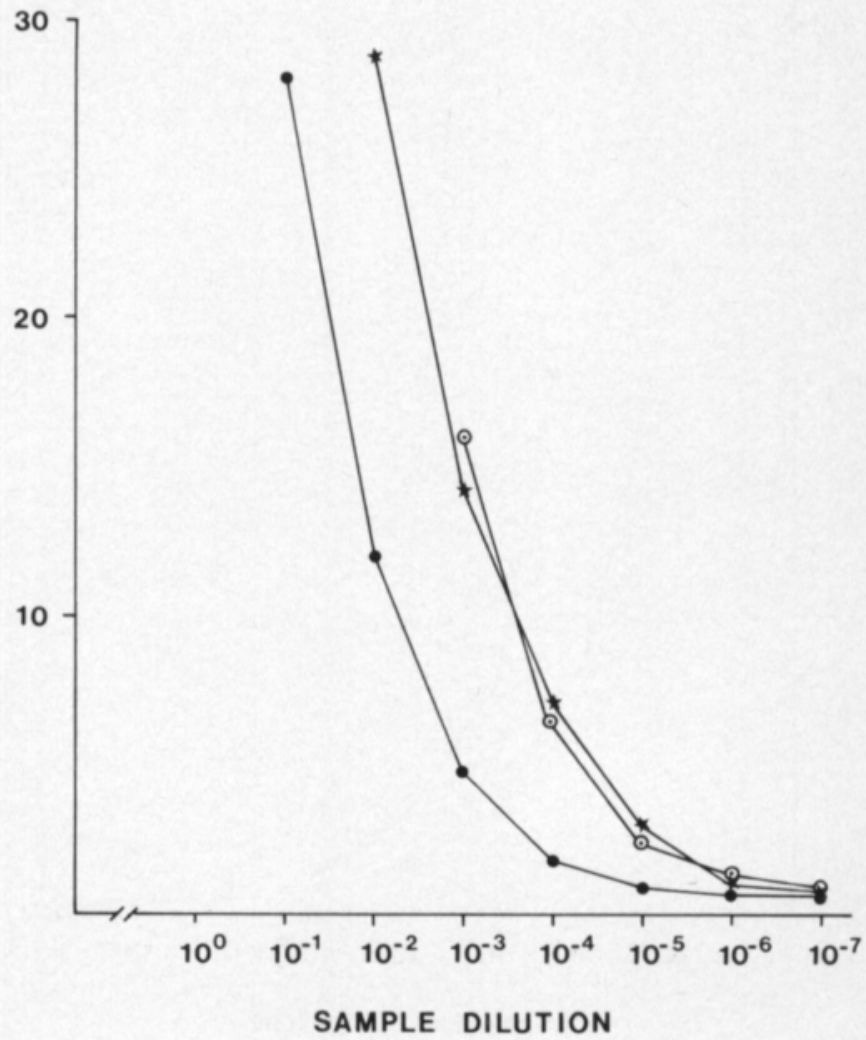


samples (Tables 38 and 39). PVX could be identified in sap from secondarily infected dormant tubers diluted to $10^{-3}$, in sap from sprouted tubers diluted

Table 39. The mean absorbance values obtained from comparable tests of secondarily infected potato tuber and leaf samples for PVM with the ELISA test. The plate coating and conjugate dilution was $1 \mu \mathrm{g} \mathrm{Ig} / \mathrm{ml}$ and substrate incubation was carried out for $40 \mathrm{~min}$ at $22 \mathrm{C}$. Ten virus infected $(\mathrm{V})$ and ten healthy $(\mathrm{H})$ comparable samples at the same developmental stage were tested and three replicates were done.

\begin{tabular}{|c|c|c|c|c|c|c|c|c|c|}
\hline \multirow[b]{2}{*}{ Test sample } & & \multicolumn{8}{|c|}{ Sample dilution and absorbance values at $405 \mathrm{~nm}$} \\
\hline & & $10^{\circ}$ & $10^{-1}$ & $10^{-2}$ & $10^{-3}$ & $10^{-4}$ & $10^{-5}$ & $10^{-6}$ & $10^{-7}$ \\
\hline Dormant tubers & $\mathrm{V}$ & .943 & .377 & .125 & .061 & .026 & .014 & .009 & .008 \\
\hline$n$ & $\mathrm{H}$ & .087 & .047 & .027 & .018 & .014 & .008 & .006 & .006 \\
\hline Sprouted tubers & V & $>2$ & .690 & .244 & .105 & .038 & .020 & .011 & .007 \\
\hline " & $\mathrm{H}$ & .066 & .038 & .028 & .017 & .011 & .007 & .006 & .005 \\
\hline Leaf samples & V & $>2$ & $>2$ & .777 & .215 & .073 & .028 & .012 & .009 \\
\hline$n$ & $\mathrm{H}$ & .046 & .031 & .019 & .011 & .008 & .006 & .004 & .003 \\
\hline
\end{tabular}

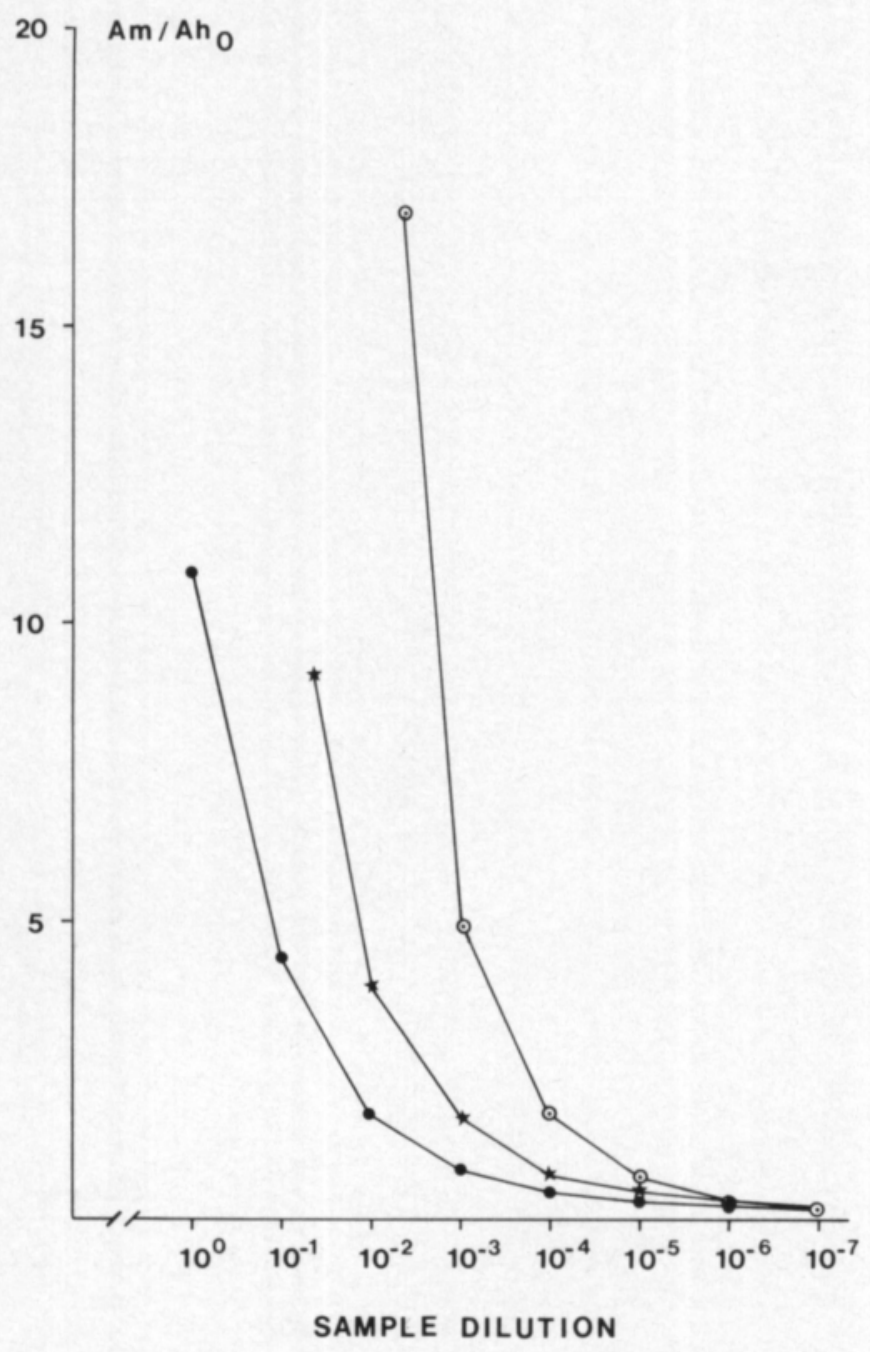

Fig. 79. The ratio $\left(A_{m} / A_{\text {ho }}\right)$ of absorbance values obtained from undiluted and diluted, infected sap and undiluted, healthy potato sap. The diseased samples were from potatoes secondarily infected with PVM and the samples were taken at different developmental stages.

- $\bullet$ = dormant tuber

$\star \star \star \quad=$ sprouted tuber

$\circ \circ \circ=$ leaf sample

Substrate incubation was carried out for $40 \mathrm{~min}$ at 22 C. 
to $10^{-4}$ and in leaf sap diluted to $10^{-5}$ (Table 38 , Fig. 78 ). The non-specific reaction was low in all tests.

The variation among the absorbance values obtained for the critical sample dilution was as follows: dormant tubers $\left(10^{-3}\right)=.217-.370$, sprouted tubers $\left(10^{-4}\right)=.259-.442$ and leaf samples $\left(10^{-5}\right)=.170-.241$.

PVM identification in dormant tubers was still reliable in $10^{-1}$ diluted sap, in sprouted tubers in $10^{-2}$ diluted sap and in secondarily infected leaves in $10^{-3}$ diluted sap. During sprouting the virus concentration increased markedly and the non-specific reaction decreased becoming insignificantly low (Table 39, Fig. 79).

Fig. 80. The ratio $\left(A_{s} / A_{\text {ho }}\right)$ of absorbance values obtained from undiluted and diluted, infected sap and undiluted, healthy potato sap. The diseased samples were from potatoes secondarily infected with PVS and the samples were taken at different developmental stages.

- $\bullet$ = dormant tuber

$\star \star \star *=$ sprouted tuber

$\circ \circ \circ=$ leaf sample

Substrate incubation was carried out for $40 \mathrm{~min}$ at 22 C.

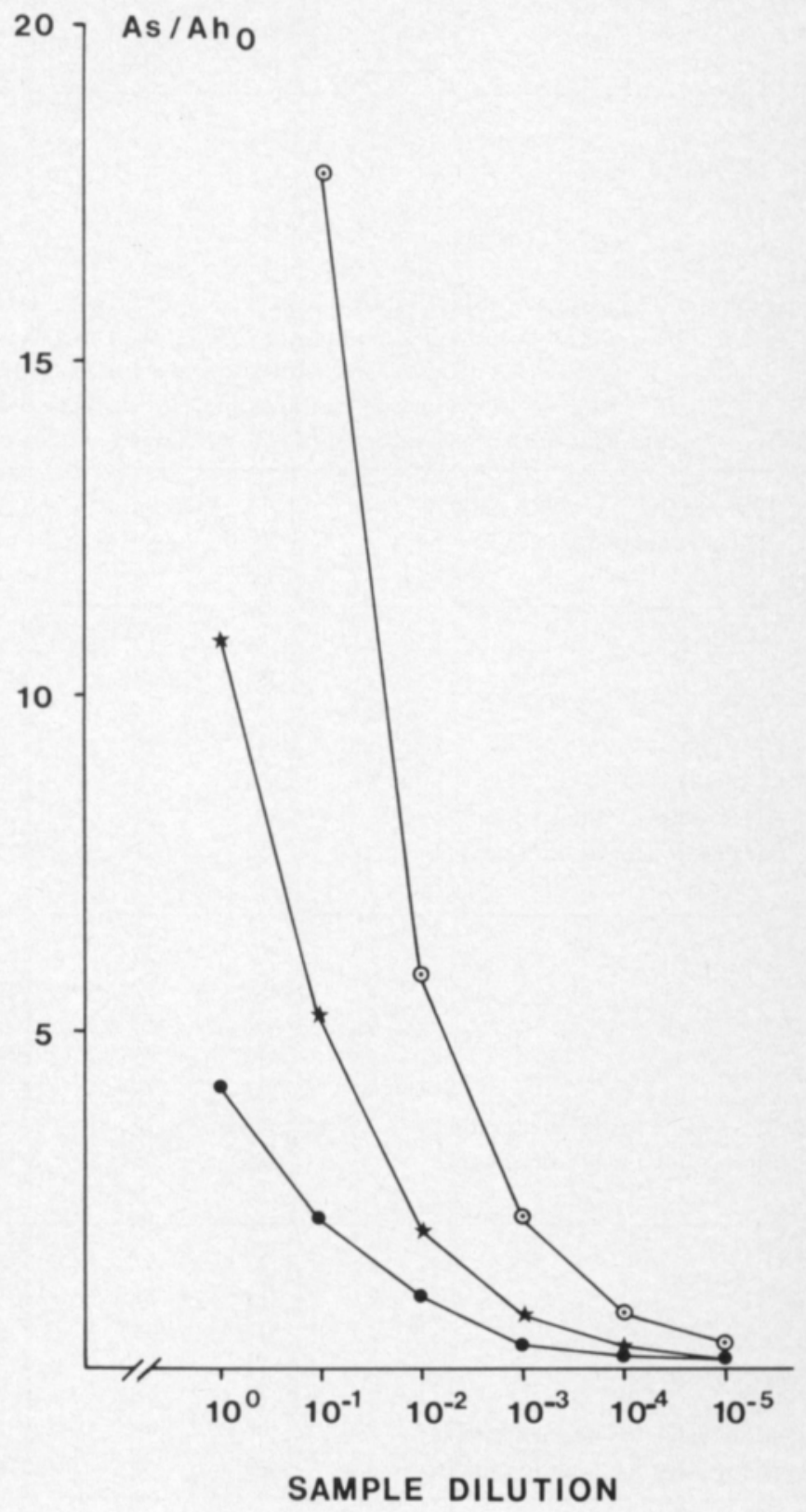


Table 40. The mean absorbance values obtained from comparable tests of secondarily infected potato tubers and leaf samples for PVS with the ELISA test. The plate coating and conjugate dilution was $1 \mu \mathrm{g} \mathrm{Ig} / \mathrm{ml}$ and the substrate incubation was carried out for $40 \mathrm{~min}$ at $22 \mathrm{C}$. Ten virus infected $(\mathrm{V})$ and ten healthy $(\mathrm{H})$ comparable samples at the same developmental stage were tested and three replicates were done.

\begin{tabular}{lccccccc}
\hline & & \multicolumn{8}{c}{ Sample dilution and absorbance values at $405 \mathrm{~nm}$} \\
Test sample & & $10^{\circ}$ & $10^{-1}$ & $10^{-2}$ & $10^{-3}$ & $10^{-4}$ & $10^{-5}$ \\
\hline Dormant tubers & $\mathrm{V}$ & .447 & .233 & .122 & .046 & .021 & .011 \\
- -- & $\mathrm{H}$ & .111 & .064 & .043 & .025 & .011 & .008 \\
Sprouted tubers & $\mathrm{V}$ & 1.020 & .508 & .161 & .072 & .031 & .018 \\
-"- & $\mathrm{H}$ & .094 & .057 & .028 & .019 & .016 & .011 \\
Leaf samples & $\mathrm{V}$ & $>2$ & 1.336 & .397 & .149 & .051 & .021 \\
-"- & $\mathrm{H}$ & .071 & .046 & .024 & .020 & .016 & .011 \\
\hline
\end{tabular}

Table 41. The mean absorbance values obtained from comparable tests of secondarily infected potato cv. Record tuber and leaf samples for PVY with the ELISA test. The plate coating and conjugate dilution was $1.4 \mu \mathrm{g} \mathrm{Ig} \mathrm{/ml} \mathrm{and} \mathrm{substrate} \mathrm{incubation} \mathrm{was} \mathrm{carried} \mathrm{out} \mathrm{for} 1 \mathrm{~h}$ at 22C. Five samples of each PVY isolate and ten healthy samples at the same developmental stage were tested. $\mathrm{a}=$ dormant tubers, $\mathrm{b}=$ sprouted tubers, $\mathrm{c}=$ leaves.

Test sample (and the isolate)

\begin{tabular}{|c|c|c|c|c|c|c|}
\hline a. & & $10^{\circ}$ & $10^{-1}$ & $10^{-2}$ & $10^{-3}$ & $10^{-4}$ \\
\hline (YSF 11) & 1 & .359 & .171 & .074 & .039 & .022 \\
\hline (YSF 4) & 2 & .281 & .147 & .087 & .044 & .024 \\
\hline (YSF 10) & 3 & .373 & .190 & .101 & .059 & .027 \\
\hline (YSF 15) & 4 & .391 & .194 & .122 & .064 & .031 \\
\hline (YSF 17) & 5 & .554 & .261 & .149 & .071 & .030 \\
\hline Mean value for infected samples & & .391 & .216 & .107 & .054 & .027 \\
\hline Mean value for healthy samples & & .131 & .076 & .057 & .038 & .019 \\
\hline
\end{tabular}

Sample dilutions and absorbance values at $405 \mathrm{~nm}$

b.

\begin{tabular}{cccccccc}
\hline & 1 & .404 & .264 & .092 & .050 & .032 & .016 \\
& 2 & .419 & .279 & .107 & .054 & .037 & .015 \\
& 3 & .647 & .427 & .164 & .087 & .044 & .020 \\
& 4 & .612 & .434 & .198 & .098 & .045 & .020 \\
& 5 & .843 & .459 & .271 & .132 & .076 & .037 \\
Mean value for infected samples & & .585 & .373 & .166 & .084 & .047 & .021 \\
$\begin{array}{c}\text { Mean value for healthy samples } \\
\text { c. }\end{array}$ & & .076 & .054 & .038 & .026 & .021 & .015 \\
\hline & & & & & & & \\
\hline & 1 & .717 & .671 & .392 & .140 & .059 & .023 \\
& 2 & .784 & .713 & .403 & .161 & .072 & .034 \\
& 3 & .912 & 1.014 & .549 & .213 & .092 & .040 \\
Mean value for infected samples & 4 & .871 & .999 & .447 & .244 & .117 & .051 \\
Mean value for healthy samples & 5 & 1.166 & 1.304 & .714 & .381 & .171 & .074 \\
\hline
\end{tabular}


The variation between the absorbance values obtained from the undiluted virus infected samples was as follows: dormant tubers $=.761-1.201$; sprouted tubers $=1.116->2.0$; leaves, all values more than 2.0.

The identification of PVS was not always reliable in dormant secondarily infected tubers but with sprouted tubers no difficulties existed. The virus concentration greatly increased during sprouting and when finally tested in leaves the virus could be reliably detected in $10^{-3}$ diluted sap (Table 40, Fig. 80).

The variation between the absorbance values obtained from the undiluted virus infected samples was as follows: dormant tubers $=.375-.636$, sprouted tubers $=.779-1.475$ and leaves $=1.761->.2 .0$.

Potato virus $\mathrm{Y}$ could be reliable detected in secondarily infected sap from sprouted tubers or leaves (Table 41, Fig. 81). In sap from dormant tubers PVY could be also detected but the level of non-specific reactions was too high for the test to be useful.

The variation between the absorbance values obtained from the undiluted virus infected samples was as follows: dormant tubers $=.214-.582$, sprouted

Fig. 81. The ratio $\left(A_{y} / A_{\text {ho }}\right)$ of absorbance values obtained from undiluted and diluted, infected sap and undiluted, healthy potato sap. The diseased samples were from potatoes secondarily infected with PVY and the samples were taken at different developmental stages.

$\bullet \bullet-$ dormant tuber

$\star \star \star \star=$ sprouted tuber

$\circ \circ \circ=$ leaf sample

Substrate incubation was carried out for $1 \mathrm{~h}$ at $22 \mathrm{C}$.

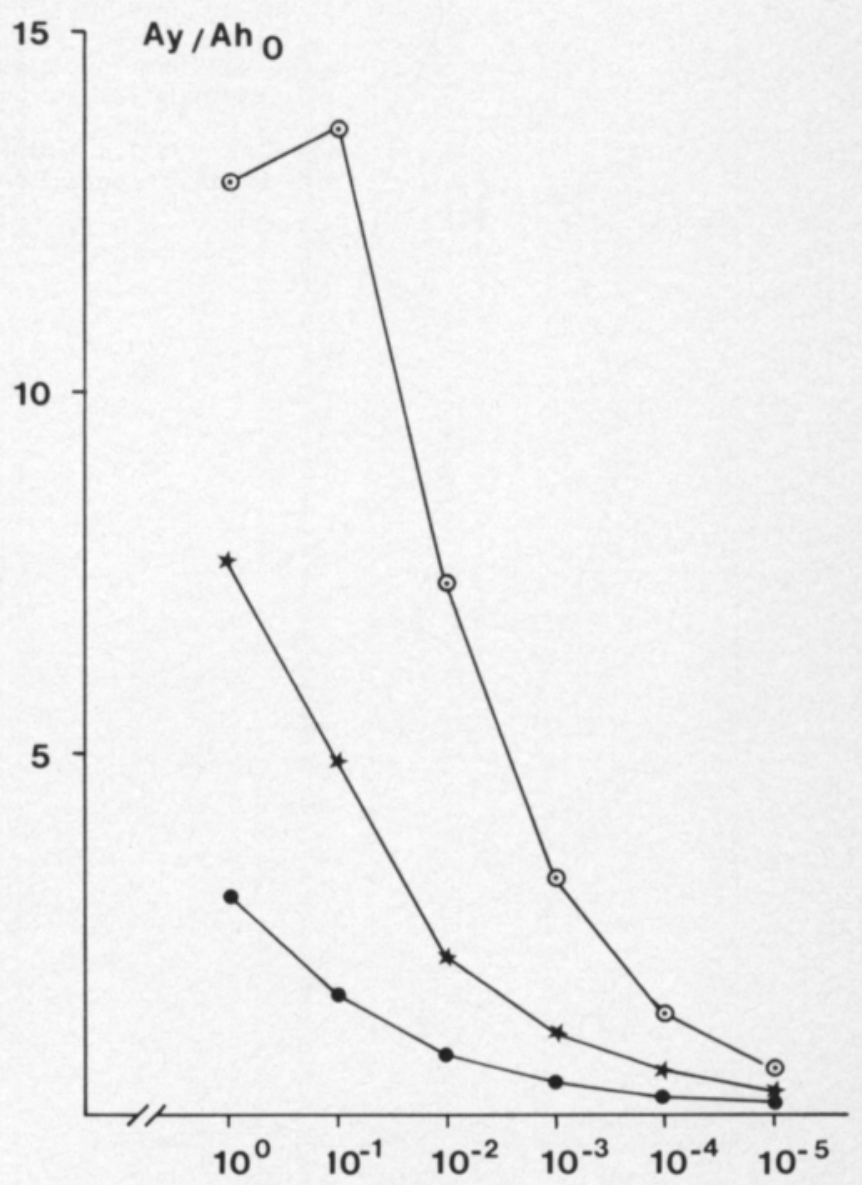

SAMPLE DILUTION 
tubers $=.361-.966$ and leaves $=.482-1.417$. The values for the healthy controls were as follows: .088-.157, .049-.094 and .046-.083 respectively.

2.3.4.2. Identification of known isolates of PVY, PVA and PLRV with foreign test reagents

A commercial reagent for PVY made by the Boehringer-Mannheim Ltd gave rather specific reaction absorbance values when tuber or leaf samples were tested. The absorbance values for the $\mathrm{Y}^{\circ}$ strain isolates were markedly higher than those for the $\mathrm{Y}^{\mathrm{n}}$ strain isolates. The specific absorbance values $\left(A_{y} / A_{h o}\right)$ calculated from the absorbance values of the leaf material tested were high (Fig. 82) particularly for the $\mathrm{Y}^{\circ}$ strain isolates. The specific

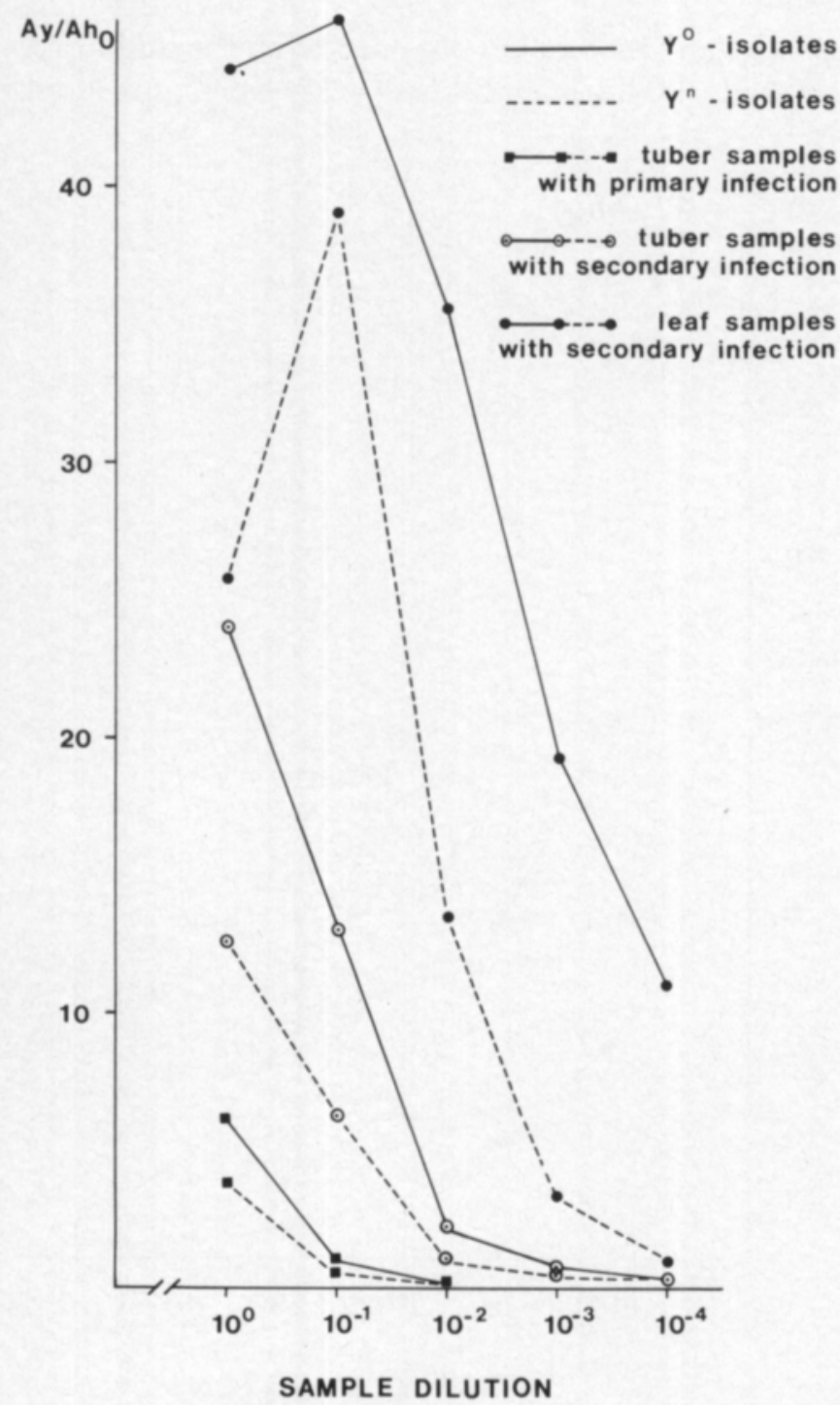

Fig. 82. Specific reaction ratios for PVY-ELISA -reagent from the BoehringerMannheim Ltd calculated from the absorbance values of undiluted and diluted PVY infected $\left(A_{y}\right)$ and healthy undiluted $\left(\mathrm{A}_{\text {ho }}\right)$ potato samples at different developmental stage. Substrate incubation was carried out for $1 \mathrm{~h}$ at $22 \mathrm{C}$. 
absorbance values calculated from the readings of the tuber material tested were noticeably lower because of the moderately high non-specific absorbance values (from .028 to .071 ) obtained for healthy tubers.

Potato virus A could be detected in secondarily infected tubers or leaves with a commercial reagent made by the Boehringer-Mannheim Ltd. The reactions showed high virus specificity with low values for the background and healthy plant material. The absorbance values for healthy leaves were $.043-.063$ and for healthy tubers $.024-.042$. The virus concentration in all samples was very low which resulted in a rapid decrease in the readings and the specific absorbance values $\left(A_{a} / A_{h o}\right)$ when the samples were diluted (Fig. $83)$.

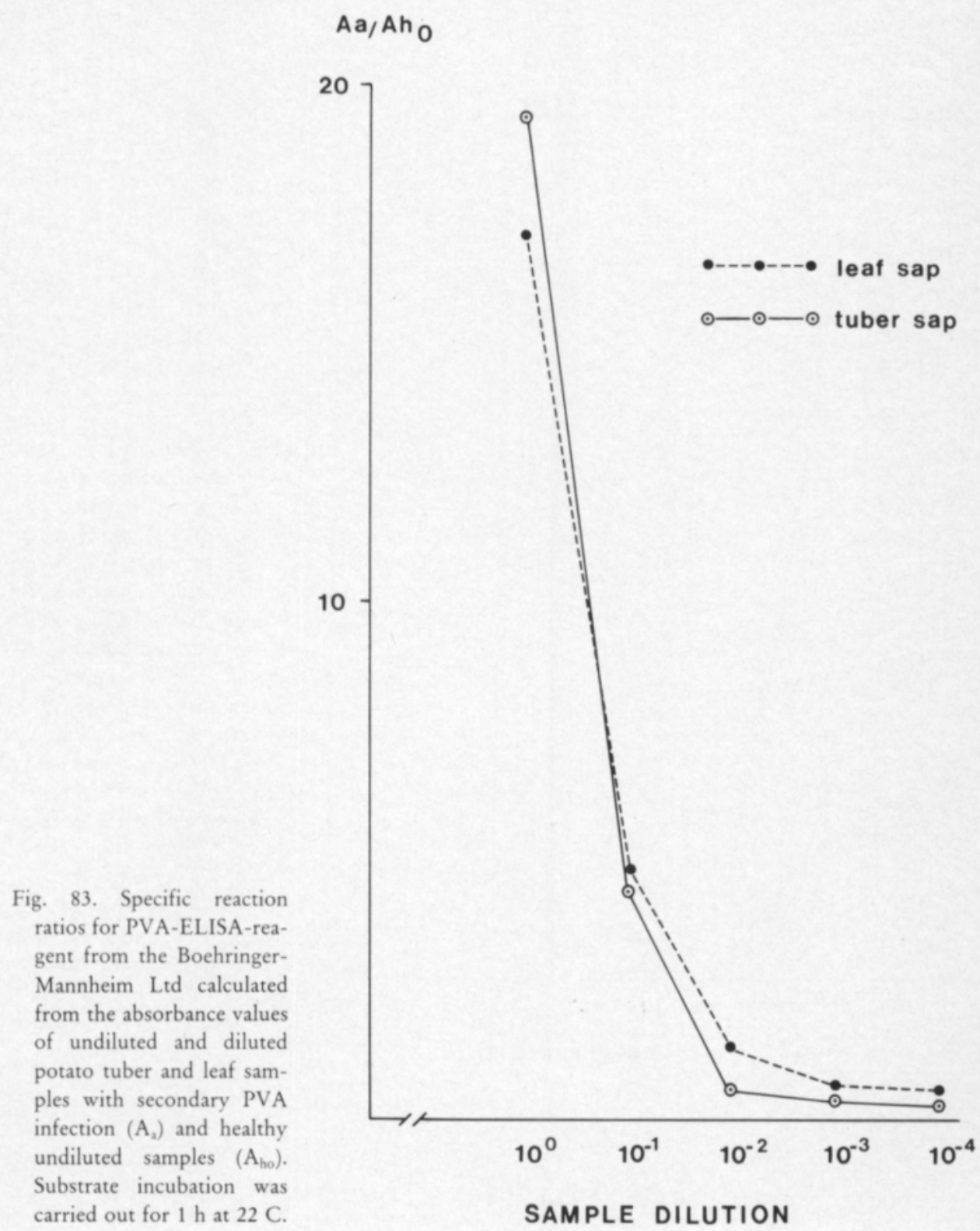


Potato leaf roll virus could be reliably identified in secondarily infected leaves or tubers with a commercial reagent made by Boehringer-Mannheim Ltd and with a reagent made indigenously from an antiserum prepared by TAMADA and HARRISON (1980). The virus could be detected also in primarily infected tubers but large variation and unclear low readings were obtained. The low virus concentration in all samples could be seen from the rapidly decreasing specific absorbance values $\left(A_{v} / A_{\text {ho }}\right)$ calculated from comparable absorbance values for virus infected and healthy samples. In diluted tuber sap the virus cannot be reliably detected after being diluted to more than $10^{-1}$ (Fig. 84). The absorbance values obtained for healthy tuber samples varied from .059 to .108 and those for leaf samples from .041 to .046 .

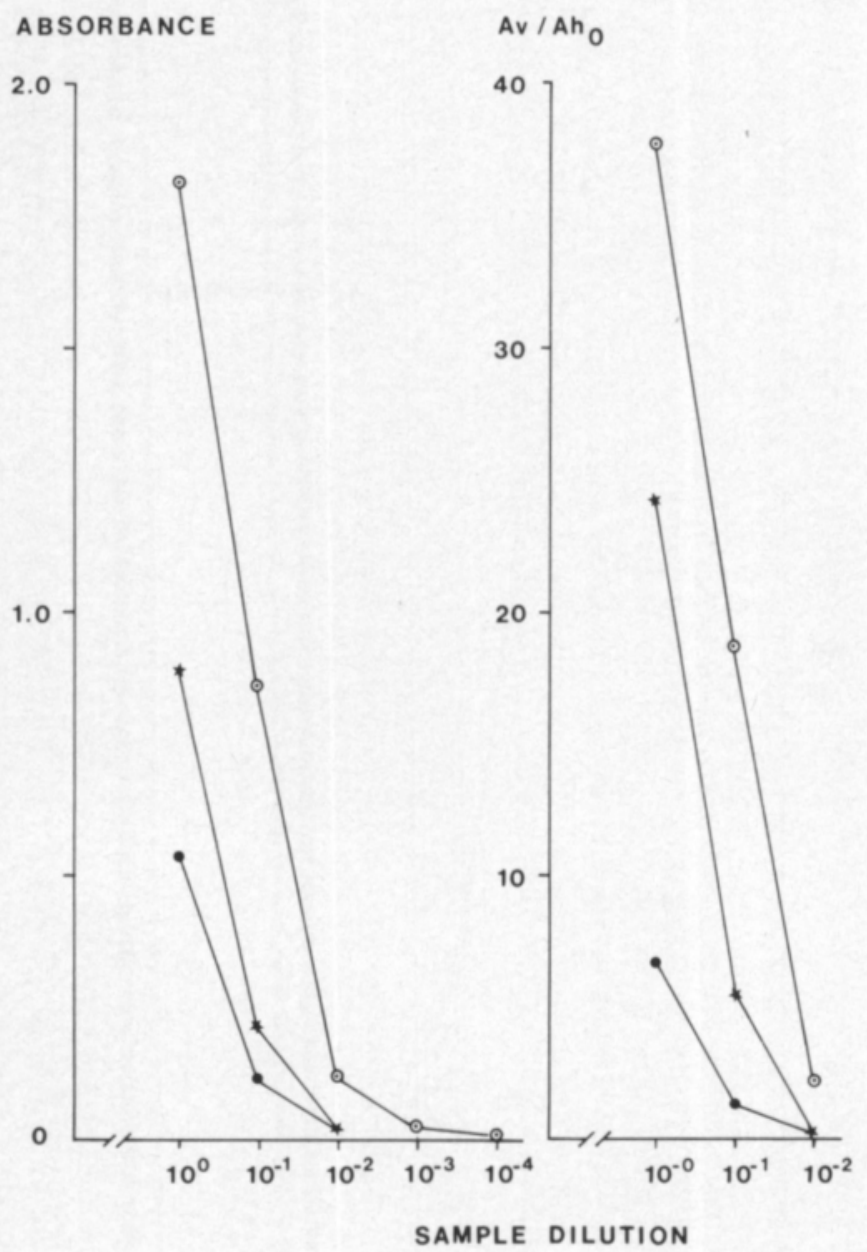

Fig. 84. Absorbance values obtained for potato tubers with primary and secondary PLRV infections and leaf samples with secondary PLRV infections. The ratio of absorbance values for infected samples $\left(A_{v}\right)$ and healthy samples $\left(A_{\text {ho }}\right)$ shows the specificity of the reaction. Substrate incubation was carried out for $1 \mathrm{~h}$ at $22 \mathrm{C}$.

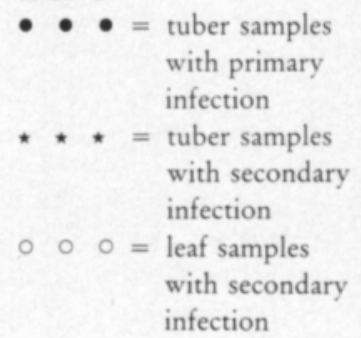


In the routine testing of potatoes with the ELISA method, the results obtained for PVX and PVM were satisfactory at all stages of development but for PVS and PVY a significantly higher number of infected samples were detected from sprouts or leaves than from dormant tubers (Table 42).

The concentrations of the same viruses in different cultivars at the same developmental stage were similar according to the readings obtained. Reliable comparisons between the readings obtained from dormant tubers are not possible because primarily infected tubers infected with variable virus concentrations also existed.

The concentrations of all viruses greatly increased after tuber dormancy was broken. Due to this the non-specific reaction became insignificant and the test reliability improved (Fig. 85).

Table 42. The percentage of virus infected potatoes as detected with the ELISA test from comparable samples of three potato cultivars at different developmental stages, $a=$ dormant tubers, $b=$ sprouted tubers, $\mathrm{c}=$ leaves. + indicates the number of infected samples/number of tested samples, $\%$ indicates the agreement with the results from c.

\begin{tabular}{|c|c|c|c|c|c|c|c|c|}
\hline \multirow{3}{*}{\multicolumn{2}{|c|}{$\begin{array}{l}\text { Viruses and samples } \\
\text { tested }\end{array}$}} & \multicolumn{7}{|c|}{ Potato cultivar and test results } \\
\hline & & \multicolumn{2}{|c|}{ Ostara } & \multicolumn{2}{|c|}{ Saturna } & \multicolumn{2}{|c|}{ Hja's Tuomas } & \multirow[b]{2}{*}{$\overline{\mathrm{X}} \%$} \\
\hline & & + & $\%$ & + & $\%$ & + & $\%$ & \\
\hline \multirow[t]{3}{*}{ PVX } & a. & $3 / 138$ & 100.0 & $71 / 106$ & 100.0 & $48 / 150$ & 100.0 & 100.0 \\
\hline & b. & 3 & 100.0 & 71 & 100.0 & 48 & 100.0 & 100.0 \\
\hline & c. & 3 & $(100.0)$ & 71 & $(100.0)$ & 48 & $(100.0)$ & \\
\hline \multirow[t]{3}{*}{ PVS } & a. & $16 / 138$ & 76.2 & $49 / 106$ & 74.2 & $79 / 150$ & 72.5 & 74.3 \\
\hline & b. & 21 & 100.0 & 63 & 95.5 & 106 & 97.3 & 97.3 \\
\hline & c. & 21 & $(100.0)$ & 66 & $(100.0)$ & 109 & $(100.0)$ & \\
\hline \multirow[t]{3}{*}{ PVM } & a. & $10 / 138$ & 100.0 & $24 / 106$ & 100.0 & $36 / 150$ & 97.3 & 99.1 \\
\hline & b. & 10 & 100.0 & 24 & 100.0 & 37 & 100.0 & 100.0 \\
\hline & c. & 10 & $(100.0)$ & 24 & $(100.0)$ & 37 & $(100.0)$ & \\
\hline \multirow[t]{3}{*}{ PVY } & a. & $5 / 138$ & 41.7 & $39 / 106$ & 47.0 & $45 / 150$ & 50.0 & 46.3 \\
\hline & b. & 11 & 91.6 & 76 & 91.5 & 26 & 92.9 & 92.0 \\
\hline & c. & 12 & $(100.0)$ & 83 & $(100.0)$ & 28 & $(100.0)$ & \\
\hline
\end{tabular}

F values for PVS and PVY: developmental stages PVS $=275.9^{\mathrm{xxx}}, \mathrm{PVY}=477.5^{\mathrm{xx}}$ cultivar $\quad \mathrm{PVS}=2.22, \quad \mathrm{PVY}=1.45$ 


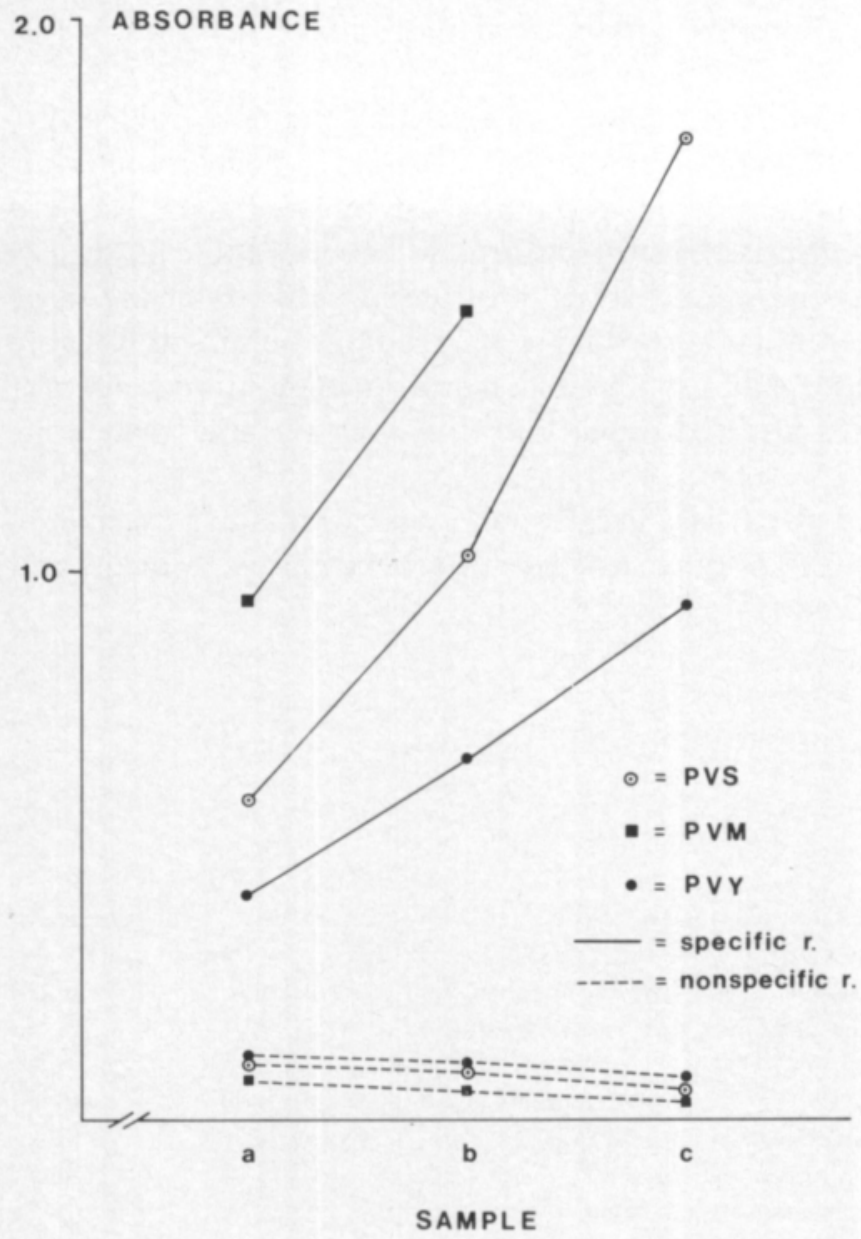

Fig. 85. Mean absorbance values from ELISA tests carried out on 399 samples of three potato cultivars at different developmental stages. The mean values of PVX and the mean values of PVM leaf samples were higher than 2.0. The nonspecific reaction of PVX was similar to PVM. Substrate incubation was carried out for $40 \mathrm{~min}$ at $22 \mathrm{C}$.

$\mathrm{a}=$ dormant tuber

$\mathrm{b}=$ tubers with sprouts

$c=$ leaf samples

2.3.5. Comparisons between the ELISA test, the chloroplast agglutination test and the A6 cut leaf test

The test results obtained from comparable sprouted tuber samples and leaf samples with the ELISA test and from the same leaf samples with the chloroplast agglutination test and with the A6 test (PVY) showed good agreement for PVX but as for the other viruses, great variation existed (Tables 43-45). The detection of PVS with the chloroplast agglutination test was particularly a problem and numerous incorrect identifications were found to be caused by the non-specificity of the test and the relatively low virus concentration in the samples (Table 43).

According to the results from the chloroplast agglutination test the mean $\%$ of infected tubers was 43.5 for PVS and 20.8 for PVM. Comparative results from the ELISA test were $49.5 \%$ for PVS infected and $28.3 \%$ for PVM infected tubers. The chloroplast agglutination test gave incorrect positive reactions $7.4 \%$ of the time for PVS and $1.8 \%$ of the time for PVM. 
Table 43. Comparative identification results for potato viruses $\mathrm{X}, \mathrm{S}$ and $\mathrm{M}$ obtained from potato leaf sap with the chloroplast agglutination test (A) and the ELISA test (E).

$+=$ reaction observed, $-=$ no reaction observed

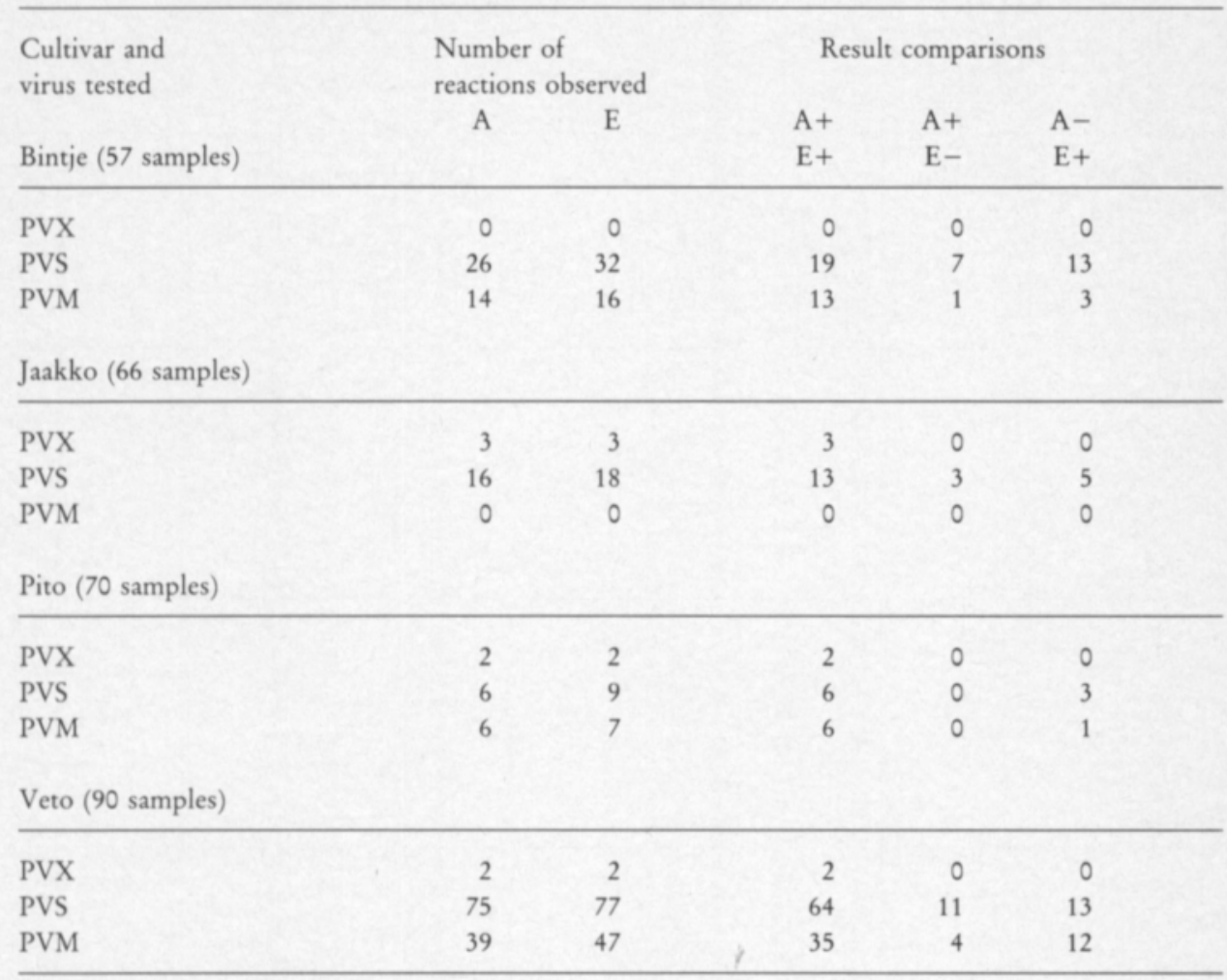

The chloroplast agglutination test failed to detect $25.0 \%$ of PVS infected and $22.8 \%$ of PVM infected samples.

PVY could be reliably detected with the A6 cut leaf test in potato leaf samples but the cut leaves also reacted with necrotic lesions to some other viruses (Table 44).

Satifactory results were also obtained in later tests for PVX and PVM when tested with the chloroplast agglutination test and the ELISA test, but for PVS the lack of agreement between tests was noticeable. Some inconsistency between test results was also observed in the identification of PVY (Table 45).

The ELISA test results from potato leaf sap were more reliable than the results from the sap of sprouted tubers from the same material, the difference in incidence between the 2 sap sources being as follows: PVX $=0.00 \%$, PVS $=8.04 \%, \mathrm{PVM}=3.41 \%$ and $\mathrm{PVY}=10.20 \%$. 
Table 44. Results from comparative identifications of potato viruses $\mathrm{X}, \mathrm{S}, \mathrm{M}$ and $\mathrm{Y}$ first in sprouted tubers with the ELISA test and later in seedling leaves grown from the same tested tubers with the chloroplast agglutination test, the A6 cut leaf test and the ELISA test. Thirty samples from each potato cultivar were tested at both developmental stages.

$\mathrm{A}=$ chloroplast agglutination test or A6 leaf test for PVY

$\mathrm{E}_{1}=$ ELISA test from sprouted tubers

$\mathrm{E}_{2}=$ ELISA test from leaves

$+=$ reaction observed

$-=$ no reaction observed

\begin{tabular}{|c|c|c|c|c|c|c|c|c|c|c|c|c|}
\hline \multirow{2}{*}{$\begin{array}{l}\text { Cultivar and } \\
\text { virus tested }\end{array}$} & \multicolumn{3}{|c|}{$\begin{array}{l}\text { Number of } \\
\text { reactions observed }\end{array}$} & \multicolumn{9}{|c|}{ Comparison results } \\
\hline & $\begin{array}{c}\mathrm{A} \\
\text { (or A6) }\end{array}$ & $E_{1}$ & $\mathrm{E}_{2}$ & $\begin{array}{c}\mathrm{A}+ \\
\mathrm{E}_{1}+\end{array}$ & $\begin{array}{l}\mathrm{A}+ \\
\mathrm{E}_{1}-\end{array}$ & $\begin{array}{l}\mathrm{A}- \\
\mathrm{E}_{1}+\end{array}$ & $\begin{array}{c}\mathrm{A}+ \\
\mathrm{E}_{2}+\end{array}$ & $\begin{array}{l}\mathrm{A}+ \\
\mathrm{E}_{2}-\end{array}$ & $\begin{array}{c}\mathrm{A}- \\
\mathrm{E}_{2}+\end{array}$ & $\begin{array}{l}\mathrm{E}_{1}+ \\
\mathrm{E}_{2}+\end{array}$ & $\begin{array}{l}E_{1}+ \\
E_{2}-\end{array}$ & $\begin{array}{l}\mathrm{E}_{1}- \\
\mathrm{E}_{2}+\end{array}$ \\
\hline PVX & 1 & 0 & 0 & 0 & 1 & 0 & 0 & 1 & 0 & 0 & 0 & 0 \\
\hline PVS & 7 & 11 & 12 & 7 & 0 & 4 & 7 & 0 & 5 & 11 & 0 & 1 \\
\hline PVM & 4 & 6 & 6 & 4 & 0 & 2 & 4 & 0 & 2 & 6 & 0 & 0 \\
\hline PVY & 23 & 20 & 22 & 20 & 3 & 0 & 20 & 3 & 2 & 20 & 0 & 2 \\
\hline Ostara & & & & & & & & & & & & \\
\hline PVX & 1 & 1 & 1 & 1 & 0 & 0 & 1 & 0 & 0 & 1 & 0 & 0 \\
\hline PVS & 17 & 23 & 23 & 16 & 1 & 7 & 16 & 1 & 8 & 23 & 0 & 0 \\
\hline PVM & 18 & 10 & 11 & 10 & 8 & 0 & 11 & 7 & 0 & 10 & 0 & 1 \\
\hline PVY & 9 & 6 & 7 & 6 & 3 & 0 & 7 & 2 & 0 & 6 & 0 & 1 \\
\hline
\end{tabular}

Saturna

\begin{tabular}{lrrrrrrrrrrrr}
\hline PVX & 16 & 18 & 18 & 15 & 1 & 3 & 15 & 1 & 3 & 18 & 0 & 0 \\
PVS & 6 & 12 & 13 & 6 & 0 & 6 & 6 & 0 & 7 & 12 & 0 & 1 \\
PVM & 6 & 9 & 9 & 6 & 0 & 3 & 6 & 0 & 3 & 9 & 0 & 0 \\
PVY & 20 & 13 & 14 & 11 & 9 & 2 & 12 & 8 & 2 & 13 & 0 & 1
\end{tabular}

Hja's Timo

\begin{tabular}{lllllllllllll}
\hline PVX & 0 & 0 & 0 & 0 & 0 & 0 & 0 & 0 & 0 & 0 & 0 & 0 \\
PVS & 4 & 8 & 9 & 3 & 1 & 5 & 3 & 1 & 6 & 8 & 0 & 1 \\
PVM & 3 & 3 & 3 & 3 & 0 & 0 & 3 & 0 & 0 & 3 & 0 & 0 \\
PVY & 6 & 5 & 5 & 4 & 2 & 1 & 5 & 1 & 1 & 5 & 0 & 0 \\
\hline
\end{tabular}


Table 45 . The $\%$ infected samples obtained for 4 potato cultivars $(2 \times 523$ samples $)$ tested comparably first in sprouted tubers with the ELISA test $\left(\mathrm{E}_{1}\right)$ and later in leaf material grown from the tested tubers with the ELISA test $\left(\mathrm{E}_{2}\right)$ and the chloroplast agglutination $(\mathrm{A})$ or the A6 cut leaf test (A6). The incorrect results obtained with the chloroplast agglutination test and the A6 cut leaf test are compared to the results from the simultaneous ELISA test $\left(\mathrm{E}_{2}\right)$.

\begin{tabular}{lcccc}
\hline Test method & \multicolumn{4}{c}{ Mean $\%$ of infected samples } \\
& PVX & PVS & PVM & PVY \\
\hline E $_{1}$ & 15.8 & 45.0 & 23.3 & 36.7 \\
E $_{2}$ A or A6 (PVY) & 15.8 & 48.3 & 24.2 & 40.0 \\
$\begin{array}{l}\text { Incorrect positive results } \\
\text { with A or A6 }\end{array}$ & 15.0 & 28.3 & 25.8 & 47.5 \\
$\begin{array}{l}\text { Incorrect negative results } \\
\text { with A or A6 }\end{array}$ & 10.5 & 3.5 & 24.1 & 29.2 \\
\hline
\end{tabular}

\section{Discussion}

\section{Properties of the viruses and the virus isolates}

Knowledge of the properties of virus strains and isolates has become increasing important since the introduction of highly sensitive and specific methods for virus identification. The practicality of these new principles, particularly for the identification of potato viruses, has emphasized the need for a better biological understanding of the viruses.

Prior to this study no systematic information about the strains or isolates of potato viruses occurring in Finland was available and similarly the special problems associated with their identification were unknown. The materials for this study were therefore carefully selected to represent the viral and viral isolate diversity present in Finland.

The seven potato viruses which occur in Finland are all widely known. However, potato leaf roll virus has only recently been transmitted here via its natural vectors, probably over the sea from the Baltic countries.

In addition to the viral diseases discussed here, the following viral or similar potato diseases may occur in Finland: "Potato mop top" (CALVERT \& HARRISON 1966, HARRISON \& JONES 1970), Potato aucuba mosaic (KASSANIS \& GOVIER 1970), "Potato spindle tuber" disease (SCHULZ \& FOLSOM 1923, DIENER \& RAYMER 1971) and "Potato yellow dwarf" (BARRUS \& CHUPP 1922, BLACK 1970).

Among the potato viruses found in Finland only PVX and PVY had clearly detectable strains. The ring spot strain of PVX does not commonly occur according to LAGEBURG et al. (1950), however isolates including this strain were found in several lots of imported seed potato from countries in Central Europe. Although PVY strains $\mathrm{Y}^{\circ}$ and $\mathrm{Y}^{\mathrm{n}}$ are commonly found in Europe, as reported by BODE (1959) and de BOKX and PIRON (1977), no 
reliable information about strain distribution and strain interrelationships exists and thus observations of strain occurrence could not be compared with any similar results. $\mathrm{Y}^{\mathrm{c}}$ strain isolates were not found in the course of this study, which together with the observations of LINDSTEN (1981), indicates that the strain does not occur in Scandinavia.

The strain classification of PVY should be revised. Suitable criteria exist for $\mathrm{Y}^{\mathrm{n}}$ strain isolate classification, but the criteria for the $\mathrm{Y}^{\circ}$ and $\mathrm{Y}^{\mathrm{c}}$ strains is unclear. Also isolates not included in any of these strains are found, as reported by de BOKX et al. (1975) and WEIDEMANN and KOENIG (1979).

The most important of the potato viruses which occur in Finland is PVY which in several domestic and foreign field experiments has been shown to be a serious disease causing virus. The symptoms and the disease severity, however, vary greatly depending on the virus isolate and potato cultivar as also shown by WEIDEMANN (1981).

Observations of severe disease caused by potato leaf roll virus and virus $M$ agree with those reported by REESTMAN (1970) and CHRZANOWSKA (1976).

Although PVX and PVS were still very common in seed potatoes produced in Finland in the 1970's, their true importance is unclear because in only a few cases were they found to induce severe disease.

Little information is available about PVA and TRV. The former is probably more common and important, as is believed in Finland. The identification methods used before the ELISA test was established were unsuitable for the detection of PVA as an individual virus. TRV may be of local importance as TAPIO (1972b) and KURPPA (1982) have reported rich Trichodorid nematode populations occurring in field and plant nursery soils, and SCHMELZER (1957) and KRISTENSEN (1962) have reported the presence of common weeds, which can maintain the virus in similar soils. According to GUGERLI (1977), TRV transmission potential is high because of many sources for infection and the high transmission capacity of the Trichodorid nematodes found in the soil.

No explanation was found for the rapid transmission potential of the ring spot strain isolates of PVX in the field experiments. However, all the isolates were found to be only mechanically transmittable. No data is available to be able to compare the similar behaviour of PVS and PVM in certain susceptible and resistant potato cultivars.

All the viruses studied could be detected with susceptible test plant species. However, the reaction of certain viruses to certain test plants differed from the literature descriptions. Lycopersicon esculentum cv. Nevskij showed severe systemic symptoms after inoculation with PVS, unlike the symptoms KOWALSKA et al. (1976) have reported. No reliable local hosts were found for PVM although HIRUKI (1970) has reported Phaseolus vulgaris cv. Red Kidney and KAHN and MONROE (1970) Datura metel as being such hosts. Little information is available about the local reaction of PVX strains to A6 and Solanum demissum Y, which showed necrotic lesions after inoculation with the ring spot strain isolates.

The most suitable test plant for PVY strain classification was Nicotiana 
tabacum cv. Samsun as reported by BAWDEN and KASSANIS (1951) and RICHARDSON (1958). Further information about PVY classification, obtained with the use of Physalis floridana and Solanum chacoence, have been reported by EASTON et al. (1958) and de BOKX (1974) but no information about the comparative use of $S$. demissum A for PVY strain separation is available.

Symptom variation between the isolates of the other viruses was less clear so no strain classification was carried out. However, variation in aphid transmissibility and symptoms in Nicotiana debneyi similar to that reported by BODE \& WEIDEMANN (1971) and MacKINNON (1974) was found between the PVS isolates. The symptom variation observed between the PVM isolates in Solanum rostratum and Lycopersicon chilense agreed with that described by ROSS (1968), KOWALSKA and WAS (1976) and KOWALSKA (1978).

The physical values obtained for domestic virus isolates differed slightly from those published in the literature. The thermal inactivation point values $(66-69 \mathrm{C})$ for the ring spot strain isolates of PVX agreed with those of LAGEBURG et al. (1950) but the values $(63-66 \mathrm{C})$ for the mild mosaic strain isolates were lower than those reported by KÖHLER (1962). FRIBOURG (1975) has, however, reported even lower values for the mild mosaic strain of PVX. The thermal inactivation point values $(54-57 \mathrm{C})$ and the dilution end point values $\left(10^{-2}\right)$ for PVS were lower than those reported by WETTER and BRANDES (1956). The thermal inactivation point value $(51 \mathrm{C})$ for the PVY ${ }^{\circ}$ strain isolates was low compared to those of DARBY et al. (1951) but the values $(51-57 \mathrm{C})$ for the $\mathrm{PVY}^{\mathrm{n}}$ strain isolates were similar to those reported by DELGADO-SANCHEZ and GROGAN (1970). The dilution end point values for all PVY isolates agreed with published values.

The purification method of SHEPARD (1972) used routinely for the purification of PVX, PVS and PVM, gave satisfactory results although some particle aggregation was found after PEG-concentration of the viruses. The yields of purified PVS and PVM were slightly greater than those reported by PROLL and RICHTER (1979). Lycopersicon esculentum cv. Nevskij was a more suitable host for PVS purification than Nicotiana debneyi.

For the purification of PVY the method of STACE-SMITH and TREMAINE (1970) gave low yields of purified virus and was too laborious to use as a routine method. Large losses were caused by the many repeated steps in the procedure and the aggregation of the long flexous particles, as SHEPHERD and POUND (1960) and HUTTINGA (1973) have reported. The slightly modified method of LEISER and RICHTER (1978) contained essential improvements for PVY purification. The virus particles could be fairly easily separated out of almost all plant material within two days. The yields of purified virus were higher from fresh infected plant material than from frozen material. The higher yields of purified virus obtained for the PVY isolates corresponded with the values of their physical properties.

For the purification of PLRV several methods published are suitable because of the stability of the virus, as shown by PETERS (1970). Purification problems caused by low virus concentration and particle accumulation in the phloem have been overcome by the enzymatic digestion of plant tissue, as 
suggested by TAKANAMI and KUBO (1979). This principle has many advantages over normal procedures but due to the high costs of the enzyme the method was abandonned. A method modified from those of ROWHANI and STACE-SMITH (1979) and CLARKE (1981) finally gave yields of purified virus almost comparable to those obtained with the method of TAKANAMI and KUBO (1979).

All viruses and virus isolates studied were found to be good or moderate immunogens although titers as high as those reported by BAGNALL et al. (1959), WETTER (1960) and BERCKS (1970) were not achieved. It should be pointed out, however, that the microprecipitin test, which was used for the titer determinations, gives "relative values" which are not always totally comparable. The dosages of purified virus widely suggested for each injection are higher than needed and may increase the non-specificity of the antisera. High titer antisera have been produced by RICHTER et al. (1979) and CLARKE (1981) using very low dosages of immunogens. Also the number of injections can be minimized in order to obtain more specific antibody responses in the rabbits.

In spite of great biological variation amongst the isolates of PVX, their serological relationships were fairly close, as earlier reported by LARSON (1943), LADEBURG et al. (1950) and FRIBOURG (1975). On the other hand marked serological differences between the isolates has been found by CHESTER (1936) and particularly MATTHEWS (1949) whose strain classification was based on serological properties. The serological properties of PVS and PVM are in accord with those reported by BAGNALL et al. (1959).

According to BAWDEN and KASSANIS (1951) the isolates of all PVY strains are serologically closely related. Significant serological variation was, however, found between the $\mathrm{Y}^{\circ}$ and $\mathrm{Y}^{\mathrm{n}}$ strain isolates, as is also reported by BARTELS (1957) and MAAT and de BOKX (1978).

Little information is available about the serological properties of some of the other potato viruses which occur in Finland. However, the TRV isolates were closely related to the PRN isolate described by HARRISON and NIXON (1959) and the PVA and PLRV isolates included strains which occur in Europe.

Of the foreign antisera, only the Danish ones were comparable to indigenous antisera. The others were stored in a freeze-dried form and were diluted to the original volyme before use. It is therefore uncertain if the dilutions were correct and whether some loss of antibody activity had occurred during storage.

No difficulties were encountered in modifying the gel diffusion methods for the identification of long flexous particles. Antisera with the same properties as reported by SHEPARD and SECOR (1969), SHEPARD (1970b) and SHEPARD et al. (1971) could be readily prepared. 


\section{Identification methods}

The traditional drop-agglutination technique can be reliably used for the serological detection of potato viruses $\mathrm{X}, \mathrm{S}$ and $\mathrm{M}$ in potato leaf sap as reported by de BOKX and MOOI (1974). The chloroplast agglutination method and its modifications have, however, several disadvantages such as low sensitivity, low specificity and the requirement of leaf sap for the test. Reliable results from clarified tuber sap with the microprecipitin test have been obtained by STASZEWICZ (1977) and with the bentonite flocculation or the latex agglutination test by KAHN et al. (1967), BERCKS (1967) and KRYLOV and GNUTOVA (1974). Some new modifications of the latex agglutination test are very sensitive, as shown by KOENIG and BODE (1978), KHAN and SLACK (1978) and TORRANCE (1980a).

The unreliable identification of PVY with the chloroplast agglutination test confirms the observations of BARTELS (1957) and BLOTSKAYA (1972). For PVY identification with the microprecipitin test, $10-20 \mu \mathrm{g} / \mathrm{ml}$ of purified virus was needed in order to obtain a clear reaction. According to these values the chloroplast agglutination test cannot be sensitive enough for the identification of this virus. Furthermore, the physiological variation between the test samples is likely to decrease the test reliability (VULIC \& ARENZ 1963 and GHENA \& VIORIGA 1970).

Little information is available about the reaction of the ring spot isolates of PVX to A6 cut leaves, which was the main problem with this biological test. De BOKX (1970a), however, has mentioned local lesions on A6 cut leaves induced by PVX, and KACZMAREK (1976) has reported symptoms caused by PVS and PVM on A6 leaves. According to de BOKX and CHRZANOWSKA (1972) PAMV and TRV may also cause local lesions on A6 leaves.

The cut leaves of Solanum chacoense reacted to all PVY isolates but they were too small for reliable virus detection, as has also been shown by de BOKX (1974). The leaves did not show reliable PVA infection and physiologically old leaves tended to show non-specific reactions. S. chacoense did not improve the detection of PVY and PVA with the cut leaf test.

The agar gel double diffusion test was not sensitive enough to be used as a routine test for identifying potato viruses. The lowest concentration of degraded virus protein detected, $10 \mu \mathrm{g} / \mathrm{ml}$, agrees with the values obtained by SHEPARD (1972) and indicates that the test is only suitable for the detection of PVX.

The single diffusion test reached the same detection sensitivity, $1 \mu \mathrm{g} / \mathrm{ml}$, as SHEPARD and SECOR (1969) and SHEPARD (1972) have reported. Higher virus concentrations were needed, however, for the identification from plant sap and the values obtained, $2.5-10 \mu \mathrm{g}$ virus $/ \mathrm{ml}$, correspond to those reported by RICHTER et al. (1977). The single diffusion test is sensitive enough for the identification of PVX, PVS and PVM in potato leaves with secondary infection and is even valid for the reliable identification of PVY from potato leaves as reported by SHEPARD et al. (1974) and RICHTER et al. (1979). The test is not suitable for the detection of viruses in tuber sap because of insufficient sensitivity and because of the non-specific reactions 
caused by lectins present in tuber sap, as has also been shown by SHEPARD (1970a). The single diffusion test was found to be a very simple and practical method to test a low number of samples. It also indicates the approximate virus concentration if a test standard is used.

Until 1979, virus purifications were carried out without the final density gradient centrifugation procedure. This is why some antisera produced before that point may have contained too many antibodies to host plant protein. However, after host antibody absorption these antisera became suitable for use in the preparation of reagents for the ELISA test.

The PVY antisera were not particularly highly titered and so were not optimal material for the preparation of reagents for the ELISA test. Antisera for the $\mathrm{Y}^{\circ}$ and $\mathrm{Y}^{\mathrm{n}}$ strains of PVY with high titers and very good specificity, however, have since been produced by KURPPA and KORHONEN (unpublished).

The values $A_{v} / A_{h}$ for the absorbance ratios of virus infected test samples and healthy comparable samples, PVX max. $>100$, PVS max. 94, and PVM max. 114 were high and are highly virus-specific, except for that of PVY which was only 23 max. When calculated from the absorbance readings from tuber samples the ratio values were somewhat lower but still noticeably higher than those that can be calculated from the comparable figures published by de BOKX et al. (1980), CLARKE et al. (1980) and BANTTARI and FRANK (1982). Test results showing more virus-specificity for PVY than published in this paper have been reported by MAAT and de BOKX (1978) and DANIEL and HUNNIUS (1980). A commercially available ELISA reagent for PVY also gave high values for the ratio of absorbances but was too specific for the $\mathrm{Y}^{\circ}$ strain. The low reaction specificity of some of the indigenous reagents was due to the low amount of enzyme present in the conjugate or to incomplete conjugation between the antibodies and the enzyme. The most favourable concentrations of reagents for the tests, $1 \mu \mathrm{g} / \mathrm{ml}$ of immunoglobulin and $1-2.5 \mu \mathrm{g} / \mathrm{ml}$ of its conjugate, are similar to the values suggested by CLARK and ADAMS (1977). The substrate incubation time was not very critical if the test reagents were highly virus-specific; one hour at room temperature was normally suitable.

The titration of the test reagents against a series of dilutions of virus infected plant sap and against non-diluted healthy sap of the same species clearly illustrated the specific function of the reagents. A straight declining line following the dilutions indicates a high virus specificity and a high percentage of virus particles reacting with the antibodies of all of the differentially diluted samples. The ratio of absorbances calculated from the values above also clearly shows the critical dilutions of different samples from which virus detection is reliable.

The lowest concentrations of purified virus (PVX $0.1 \mathrm{ng} / \mathrm{ml}$ ) and the relative dilutions (PVX $10^{-6}$ ) in plant sap detected belong to the lowest values ever reported using the direct ELISA test.

The serological relationship between PVS and PVM found by BAGNALL et al. (1959) was nearly undetectable with the ELISA test.

The serological differences between the isolates of the $\mathrm{PVY}^{\circ}$ and the 
$\mathrm{PVY}^{\mathrm{n}}$ strains were significant as tested with the ELISA method. The absorbance readings obtained from heterologously tested undiluted samples were equal to those of ten times diluted homologously tested samples. Similar results have been reported by MAAT and de BOKX (1978), who concluded from this fact that two strain specific reagents are needed for the reliable identification of PVY.

The serological variations between the isolates of PVX, PVS and PVM were not critical with regard to identification reliability. That no marked serological variation was found between the PVA and the PLRV isolates could possibly depend on the low number of samples tested. In any case, LIU and DUFFUS (1982) have reported three serotypes of PLRV which are so distantly related that strain-specific antiserum is needed for their identification.

The lack of increase in the non-specific reaction found when potato viruses $\mathrm{X}, \mathrm{S}$ and $\mathrm{M}$ were identified as a mixture using specific antibodies for each virus agree with the observations of BANTTARI and FRANK (1982).

Comparable ELISA tests from sprouted tubers and leaves gave similar results. The total agreement for PVX and the $90 \%$ or higher agreement for the other viruses tested is comparable to the results published by DANIEL and MUNZERT (1980). The remarkable increase in the specific absorbance values during tubersprouting, particularly in the identification of PVS and PVY, has also been reported (DANIEL \& HUNNIUS 1980, and BANTTARI \& FRANK 1982). The observations of low increase in the specific absorbance values of PLRV confirm the results of CLARKE et al. (1980). Unlike the findings of MAAT and de BOKX (1978), de BOKX et al. (1980) and TAMADA and HARRISON (1980), no noticeable variation in non-specific absorbance values between potato cultivars was found.

The ELISA test was more reliable than the chloroplast agglutination test for the identification of PVX, PVS and PVM. The increase in correct detection of these viruses with the ELISA test was greater than that found by DANIEL and HUNNIUS (1980) when they compared the ELISA test to the microprecipitin test.

The test results obtained for PVY with the ELISA test and the A6 cut leaf test are not totally comparable because the latter also includes the possible reactions of PVA to the leaves. For the identification of PVY, the ELISA test increased the test reliability mainly by eliminating the incorrect positive reactions caused by several other viruses to A6 cut leaves.

To determine reliable positive readings, a flexible standard ratio of the absorbance values obtained from virus infected $\left(A_{v}\right)$ and comparable healthy $\left(A_{h}\right)$ samples (that is, $A_{v}>3 A_{h}$ ) is a precise and better measure than a given exact positive value (for example, 0.100 ) for each test reagent. In cases of abnormally high background values wrong determinations easily occur if inflexible standard values are used.

For the identification of PLRV the ELISA test is far superior to the older methods. In this study the ELISA test was satisfactory in the detection of PLRV in potato tubers and leaves, and this agrees with the observations of CASPER (1977a), GUGERLI (1979) and DANIEL and MUNZERT (1982). 
The ELISA test helps to identify PVA as an individual virus apart from PVY. It is also possible to identify TRV in potatoes with the ELISA test although according to GUGERLI (1979) a rather high virus concentration is needed for reliable detection. As well the large serological variability and the occurence of NM-isolates with TRV, as reported by HARRISON and ROBINSON $(1978,1982)$, causes serious problems.

The ELISA method is a great improvement in potato virus identification because all of the important viruses can be detected simultaneously with this method. Potato tubers are always unevenly infected by viruses and tubers with late primary infections may be infected with viruses in extremely low concentrations. In addition to coping with these conditions, the ELISA test can be used to reliably detect late primary infections in sprouted tubers, as BANTTARI and FRANK (1982) have also shown.

The ELISA test is being continually improved as a tool for intensive research and thus new modifications of it will be established yearly. The main goals of further research might be the minimization of non-specific reactions and the production of non-strain-specific reagents for routine work.

\section{E. Summary}

The aim of this study was to improve the knowledge of the viruses and the virus strains which occur in potatoes in Finland in order to solve the problems associated with their reliable identification. To achieve this purpose many viruses were isolated between 1975 and 1982 from various selected sources.

In the course of this study the antisera required for the serological studies were prepared for some isolates found typical of a given virus but also antisera of foreign origin, including commercially available reagents for the ELISA test, were used.

The following seven potato viruses were identified: potato virus $\mathrm{X}$ (PVX), potato virus S (PVS), potato virus M (PVM), potato virus Y (PVY), potato virus A (PVA), potato leaf roll virus (PLRV) and tobacco rattle virus (TRV).

PVX isolates occurring in Finland include two type strains, which are the normal (or the "mild mosaic" strain) and the ring spot strain. Similarly PVY isolates include the strains $\mathrm{Y}^{\circ}$ and $\mathrm{Y}^{\mathrm{n}}$. Both strains of PVY occur in the southern parts of Finland but in the northwestern areas, where seed potato is mainly produced, only $\mathrm{Y}^{\mathrm{n}}$ strain isolates were found. The variability among the isolates of the other viruses was less noticeable and so they were not classified into distinct strains. All of the viruses and their isolates could be detected and also identified according to their symptomology in test plants but some of the symptom observations disagreed markedly with those reported in the literature.

Potato viruses X, S, M and Y were very common in Finnish commercial seed potatoes in the middle of the 1970's but the occurrence of viruses X, S 
and $\mathrm{M}$ has since decreased as increasing quantities of healthy seed stock have become available for seed potato production.

PVY and PLRV were found to be highly virulent in all of the potato cultivars tested. Isolates of the $\mathrm{PVY}^{\circ}$ strain killed potato plants of the cvs. Ostara and Hja's Timo and induced necrosis in several other cultivars. Isolates of the $\mathrm{PVY}^{\mathrm{n}}$ strain induced milder symptoms in potatoes without necrosis. PLRV induced leaf-rolling of the upper leaves as primary symptoms and similar, but more severe, symptoms starting from the basal leaves as secondary symptoms. In addition red coloration or bronzing of the leaves was typical of this virus. Secondary infection of PLRV caused a decrease of $77 \%$ in tuber yield of individual plants of the cv. Sieglinde grown in field experiments. PVM and PVA induced severe disease in certain potato cultivars. Typical of the symptoms caused by PVM was dwarfing and spoonlike leaf formations. The tuber yield reduction of individual plants could be as high as $50 \%$. PVA induced crinkle, chlorosis and mosaic in potato leaves. The remaining viruses caused generally mild symptoms in potatoes.

All of the aphid-borne viruses were easily transmitted if sources for infection were available. The highest infection potential was shown by PVY. Significant differences in aphid transmissibility between the PVS isolates were found. The ring spot strain isolates of PVX were more readily transmitted in the field than the "mild mosaic" strain isolates. However, only the mechanical means of transmission was demonstrated for both strains. Large variability was found in the infection sensitivity of the potato cultivars and several of them were simultaneously either susceptible or resistant to PVS and PVM.

All of the viruses studied could be purified from infected plant material using published methods or improved modifications of them. The highest amounts of virus purified from $1 \mathrm{~kg}$ of infected plant material were as follows: PVX $640 \mathrm{mg}$, PVS $31 \mathrm{mg}$, PVM $48 \mathrm{mg}$, PVY $26 \mathrm{mg}$, PVA $12 \mathrm{mg}$, PLRV $1.1 \mathrm{mg}$ and TRV $85 \mathrm{mg}$. The antisera produced for the selected isolates of PVX, PVS, PVM and PVY reached titers of between 1/1024 and 1/8192 as determined with the microprecipitin test. The titers of the foreign antisera to the Finnish virus isolates were lower than those of the indigenous antisera. The titers of the antisera produced for the agar gel diffusion tests were 1/128 (PVX), 1/32 (PVS) and 1/64 (PVM), as determined with the double diffusion test.

The lowest indentifiable PVX D-protein concentrations detected were 10 $\mu \mathrm{g} / \mathrm{ml}$ with the double diffusion test and $1 \mu \mathrm{g} / \mathrm{ml}$ with the single diffusion test. In potato leaf sap PVX could be identified in dilutions of 1/128 and $1 / 1024$ respectively. The lowest identifiable concentration of the same virus with the ELISA test was $0.1 \mathrm{ng} / \mathrm{ml}$. In potato leaf sap PVX could be detected in dilutions of between $10^{-6}$ and $10^{-7}$, which is equal to the dilution end point of the virus. The absorbance values of the ELISA test obtained from virus infected plant samples were more than 100 times higher than those obtained from comparable healthy samples when the absorbance values given by a freshly made substrate solution was used as the 0 standard for the readings.

The serological differences between the isolates of the $\mathrm{PVY}^{\circ}$ and the 
$\mathrm{PVY}^{\mathrm{n}}$ strains are very important when the ELISA test is used. The serological variation between the isolates of the rest of the viruses studied was insignificantly low with regard to the test reliability.

The chloroplast agglutination test and the A6 cut leaf test frequently gave incorrect reactions because of the low sensitivity and the non-specific nature of the test. A6 leaves reacted to the ring spot isolates of PVX with symptoms similar to those caused by PVY.

The agar gel double diffusion test was not sensitive enough to detect potato viruses on a routine basis but the single diffusion method could be used for the identification of PVX, PVS and PVM in secondarily infected potato leaf sap.

With the ELISA method, PVX, PVS, PVM and PVY could be reliably identified in potato leaves and sprouted tubers. The correspondence between correct positive readings from leaf sap and sap from sprouted tubers for the viruses was as follows: PVX $100 \%$, PVM $97 \%$, PVS $92 \%$ and PVY $90 \%$. Also PVA and PLRV could be identified either from leaves or sprouted tubers with this test.

The virus concentration in dormant tubers is likely to be extremely low after late primary infection. The virus concentration, however, rapidly increases during sprouting and the viruses can then be reliably detected with the ELISA test using a small piece of tuber that includes a sprout.

\section{REFERENCES}

ABU SALIH, H. S., MURANT, A. F. \& DAFT, M. J. 1968 a. Comparison of the passive heamagglutination and bentonite flocculation tests for serological work with plant viruses. J. Gen. Virol. 2: $155-166$.

- , MURANT, A. F. \& DAFT, M. J. 1968 b. The use of antibodysensitised latex particles to detect plant viruses. J. Gen. Virol. 3: 299-302.

ALLEN, T. C. \& DAVIS, J. R. 1981. Natural occurence of tobacco rattle virus and potato virus $\mathrm{X}$ among weeds. Abstr. 8th Trienn. Conf. EAPR, München. p. 166-167.

ARENZ, B. \& HUNNIUS, W. 1959. Der Einfluss verschiedener Virusarten auf die Ertragsbildung bei der Kartoffel. Bayer. Landw. J.buch 36: 163-173.

- \& HUNNIUS, W. 1961. Über die Erfassung von Y- und A-Virus durch direkte Knollenabreibungen auf A6. Bayer. Landw. J.buch 38: 444-467.

AURA, K. 1957. Suomessa viljellyn perunan virustautisuudesta. J. Sci. Agric. Soc. Finl. 29: 103-110.

BAGNALL, R. H., LARSON, R. H. \& WALKER, J. C. 1956. Potato viruses M, S, and X in relation to interveinal mosaic of the Irish Cobbler variety. Wis. Agric. Exp. Sta. Res. Bull. 198. 45 p.

- , WETTER, C. \& LARSON, R. H. 1959. Differential host and serological relationships of potato virus $\mathrm{M}$, potato virus $\mathrm{S}$, and carnation latent virus. Phytopath. 49: 435-442.

BALD, J. G. 1945. The effect of rugose mosaic on the yield of potatoes. Phytopath. 35: 585-590.

— \& NORRIS, D. O. 1945. Virus C from an old Australian variety of potato. Phytopath. 35: 591-597.

BALL, E. M. 1961. Serological tests for the identification of plant viruses. Am. Phytopath. Soc., Ithaca, New York. 16 p.

- 1974. Serological test for the identification of plant viruses. Am. Phytopath. Soc., St. Paul, Minn. 29 p. 
BANTTARI, E. E. \& FRANC, G. D. 1982. Enzyme-linked immunosorbent assay with single or combined antisera for viruses $\mathrm{S}$ and $\mathrm{X}$ in potato tubers and plants. Am. Potato J. 59: 375-387.

BARBARA, D. J. \& CLARK, M. F. 1982. Simple indirect ELISA using F(ab' $)_{2}$ fragments of immunoglobulin. Ann. Appl. Biol. 58: 315-322.

— , CLARK, M. F., THRESH, J. M. \& CASPER, R. 1978. Rapid detection and serotyping of prunus necrotic ringspot virus in perennial crops by enzyme-linked immunosorbent assay. Ann. Appl. Biol. 90: 395-399.

BAR-JOSEPH, M. \& MALINKSON, M. 1980. Hen egg yolk as a source of antiviral antibodies in the enzyme-linked immunosorbent assay (ELISA): a comparison of two plant viruses. J. Vir. Methods 1: $179-183$.

BARRUS, M. F. \& CHUPP, C. C. 1922. Yellow dwarf of potatoes. Phytopath. 12: 123-132.

BARTELS, R. 1957. Ein Beitrag zum serologischen Nachweis des Y-virus in der Kartoffel. Phytopath. Z. 30: $1-16$.

- 1970. Symptomausbildung von Viren der Kartoffel-Y-Gruppe auf A6-Blättern. Potato Res. 13: 119-128.

- 1971. Potato virus A. C.M.I./A.A.B. Descr. Pl. Viruses No 54.

BAWDEN, F. C. 1936. The viruses causing top necrosis (aeronecrosis) of the potato. Ann. Appl. Biol. 23: $487-497$.

- \& KASSANIS, B. 1951. Serologically related strains of potato virus $\mathrm{Y}$ that are not mutually antagonistic in plants. Ann. Appl. Biol. 38: 402-410.

BEALE, H. P. 1931. Serologic reaction as a means of determing the concentration of tobacco mosaic disease. Contr. Boyce Thompson Inst. 3: 529-539.

BEEMSTER, A. B. R. \& ROZENDAAL, A. 1972. Potato viruses: properties and symptoms. Viruses of potatoes and seedpotato production. Pudoc, Wageningen. p. 115-143.

BERCKS, R. 1967. Metodische Untersuchungen über den serologischen Nachweis pflanzenpatogener Viren mit dem Bentonit-Flockung Test, dem Latextest und dem Bariumsulfat test. Phytopath. Z. 58: 1-17.

- 1970. Potato virus X. C.M.I/A.A.B. Descr. Pl. Viruses No 4.

BLACK, L. M. 1970. Potato yellow dwarf virus. C.M.I./A.A.B. Descr. Pl. Viruses No 35.

BLOTSKAYA, Z. V. 1972. Sravnitel'naya otsenha metodov diagnostiki Y-virusa Kartofelya. [Comparative evaluation of methods for diagnosing virus Y.] Zashch. Rast. Mosk. 17: 18. (Ref. Rev. Pl. Path. 51: 478.)

BODE, O. 1959. Untersuchungen über das Y-virus der Kartoffel (Tabak-Rippenträune-Stämme) Mitt. Biol. Bundesanst. 97: 52-60.

- \& WEIDEMANN, H. L. 1971. Untersuchungen zur Blattlaus-Übertragbarkeit von Kartoffel-Mund -S-Virus. Potato Res. 14: 119-129.

BOKX, J. A. de. 1964. Onderszoekingen over het aantonen van aardappel- $\mathrm{Y}^{\mathrm{n}}$-virus met behulp van toetsplanten. Meded. Inst. Pl.ziektenk. Onderz. 342.

- 1967. The callose test for the detection of leafroll virus in potato tubers. Eur. Potato J. 10: 221-234.

- 1970 a. Effect of temperature on the development of local lesions on "A6" leaves after inoculation with potato virus A. Potato Res. 13: 167-174.

- 1970 b. Reactions of various plant species to inoculation with potato virus S. Neth. J. Pl. Path. 76: 70-78.

- 1974. Some remarks on the use of ' $\mathrm{TE}_{1}$ ' (Solanum chacoense) as a test plant for potato virus Y. Potato Res. 17: 323-326.

- 1975. Detection of potato virus A in potato tubers with primary or secondary infection. Meded. Fac. Landbouw. Rijksuniv. Gent 40: 807-811.

- \& CHRZANOWSKA, M. S. 1972. Symptom development on A6 following inoculation with various viruses. Potato Res. 15: 146-159.

— \& HUTTINGA, H. 1981. Potato virus Y. C.M.I./A.A.B. Descr. Pl. Viruses No 242.

- , KRATCHANOVA, B. \& MAAT, D. Z. 1975. Some properties of a deviating strain of potato virus Y. Potato Res. 18: 38-51.

— \& MOOI, J. C. 1974. Methods of quality assessment of seed potatoes. Potato Res. 17: 410-433.

— \& PIRON, P. G. M. 1977. Effect of temperature on symptom expression and relative virus concentration in potato plants infected with potato virus $\mathrm{Y}^{\mathrm{n}}$ and $\mathrm{Y}^{\circ}$. Potato Res. 20: 207-213. 
- , PIRON, P. G. M. \& COTHER, E. 1980. Enzyme-linked immunosorbent assay (ELISA) for the detection of potato viruses $\mathrm{S}$ and $\mathrm{M}$ in potato tubers. Neth. J. Pl. Path. 86: 285-290.

BONDE, R. 1953. Potato X-virus causes large losses, better seed is answer. Me Fm Res. 2: 10-12.

- \& MERRIAM, D. 1951. Controll of latent mosaic. Me Agric. Exp. Sta. Bull. 491: 47-48.

BORGHARDT, G., BODE, O., BARTELS, R. \& HOLZ, W. 1964. Untersuchungen über die Minderung des Ertrages von Kartoffelpflanzen durch Virusinfektionen. Nachr. bl. Deut. Pfl.schutzd. Berlin 16: 150-156.

BOZICEVICH, J., SCOTT, H. A. \& VINCENT, M. M. 1963. The bentonite-flocculation test for detection of plant viruses and titration of antibody. Proc. Soc. Exp. Biol. Med. 114: 794-798.

BRANDES, J. \& WETTER, C. 1963. Untersuchungen über Eigenschaften und Verwandtshaftsbeziehungen des Latenten Passiflora-Virus (Passiflora latent virus). Phytopath. Z. 49: 61-70.

- , WETTER, C., BAGNALL, R. H. \& LARSON, R. H. 1959. Size and shape of the particles of potato virus $S$, potato virus $M$, and carnation latent virus. Phytopath. 49: 443-446.

BRUMMER, V. 1946. Tutkimuksia tärkeimmistä Tammistossa esiintyneistä perunavirooseista. Hankkijan siemenjulk. 1946. p. 176-185.

BRUYN OUBOTER, M. P. de 1952. A new potato virus. Proc. 1st Conf. Potato virus Dis., Wageningen-Lisse.

CADMAN, C. H. \& HARRISON, B. D. 1959. Studies on the properties of soilborne viruses of the tobacco-rattle type occuring in Scotland. Ann. Appl. Biol. 47: 542-556.

CALVERT, E. L. 1960. Potato virus A in the variety Ulster Torch. Pl. Path. 9: 144-146.

- \& HARRISON, B. D. 1966. Potato mop-top, a soil-borne virus. Pl. Path. 15: 134-139.

CASPER, R. 1977a. Detection of potato leafroll virus in potato and in Physalis floridana by enzymelinked immunosorbent assay (ELISA). Phytopath. Z. 90: 364-368.

- 1977b. Testung von Prunus avium - Samen auf prune mit dem ELISA-Verfahren. Phytopath. Z. 90: $91-94$.

CERA, A., LOBENSTEIN, G. \& RACCAH, B. 1978. Detection of cucumber mosaic virus in viruliferous aphids by enzyme-linked immunosorbent assay. Virology 86: 542-545.

CHESTER, K. S. 1935. Serological evidence in plant-virus classification. Phytopath. 25: 686-701.

-1936 . Separation and analysis of virus strains by means of precipitin tests. Phytopath. 26: 778 -785 .

- 1937. Serological studies of plant viruses. Phytopath. 27: 903-912.

CHRZANOWSKA, M. 1976. Variation in symptoms caused by potato virus M on the variety Uran. Potato Res. 19: 141-146.

— , ZAGORSKA, H., CIESLEWICZ, I. \& STYSZKO, R. 1977. Wykrywalnosc wirusa Y ziemniaka na odcietych listkach Roslin testowysc SdY, A-6, TE 1 . Biul. Inst. Ziem. 19: 35-41.

CLARK, M. F. \& ADAMS, A. N. 1977. Characteristics of the microplate method of enzyme-linked immunosorbent assay for the detection of plant viruses. J. Gen. Virol. 34: 475-483.

- \& BARBARA, D. J. 1982. An indirect ELISA technique using $\mathrm{F}\left(\mathrm{ab}^{\prime}\right)_{2}$ fragments of immunoglobulin. Abstr. Pap. A.A.B. Meet. Dundee 23rd-26th August, 1982. p. 42.

CLARKE, R. G. 1981. Potato leafroll virus purification and antiserum preparation for enzyme-linked immunosorbent assays. Am. Potato J. 58: 291-298.

-, CONVERSE, R. H. \& KOJIMA, M. 1980. Enzyme-linked immunosorbent assay to detect potato leafroll virus in potato tubers and viruliferous aphids. Pl. Dis. 64: 43-45.

CREMER, M. C. 1952. The preparation of antiserum against potato virus Y. Proc. 1st Conf. Potato Virus Dis. Lisse-Wageningen. p. 85-87.

DANIEL, G. \& HUNNIUS, W. 1980. Nachweis der Kartoffelviren M, S, X und Y in Presssäften sekundärinfizierten Kartoffelpflanzen mit ELISA (enzyme-linked immunosorbent assay). Gesunde Pfl. 32: 118-127.

— \& MUNZERT, M. 1980. Vergleichsuntersuchungen mit ELISA (enzyme-linked immunosorbent assay) an Knollen- und Blattmaterial M-virusinfizierter Kartoffelpflanzen. Nachr.bl. Deut. Pfl. schutzd. 32: 117-120.

— \& MUNZERT, M. 1982. Nachweis des Blattrollvirus an sekundärinfizierten Kartoffelpflanzen mit ELISA. Nachr.bl. Deut. Pfl.schutzd. 34: 51-54.

DARBY, J. F., LARSON, R. H. \& WALKER, J. C. 1951. Variation in virulence \& properties of potato virus Y strains. Wis. Agric. Exp. Sta. Res. Bull. 177: 1-32.

DAVIS, J. R. \& ALLEN, T. C. 1975. Weed hosts of the tobacco rattle virus in Idaho. Am. Potato J. 52: $1-8$. 
DELGADO-SANCHEZ, S. \& GROGAN, R. G. 1970. Potato virus Y. C.M.I./A.A.B. Descr. Pl. Viruses No 37.

DIENER, T. O. \& RAYMER, W. B. 1971. Potato spindle tuber "virus". C.M.I./A.A.B. Descr. Pl. Viruses No 66.

DVORAK, M. 1927. The effect of mosaic on the globulin of potato. J. Infectious Dis. 3: 215-221. (Ref. Rev. Appl. Mycol. 28: 192-193.)

EASTON, G. D., LARSON, R. H. \& HOUGAS, R. W. 1958. Immunity to virus $Y$ in the genus Solanum. Wis. Agric. Exp. Sta. Res. Bull. 205. 32 p.

EDDINS, A. H. E., PROGTER, Q. \& WEST, E. 1946. Occurence of corky ringspot of potatoes in Florida. Pl. Dis. Rep. 30: 232-233.

ENGVALL, E. \& PERLMANN, P. 1972. Enzyme-linked immunosorbent assay ELISA. III. Quantitation of specific antibodies by enzyme-labelled anti-immunoglobulin in antigen-coated tubes. J. Immunology 109: 129-135.

ESBO, H. 1946. Potatisvirosernas utbredning i Sverige. Nord. Jordbr. Forskn. 48: 101-109.

FRIBOURG, C. E. 1975. Studies on potato virus X strains isolated from Peruvian potatoes. Potato Res. 18: $216-226$.

- \& ZOETEN, G. A. 1970. Antiserum preparation and partial purification of potato virus A. Phytopath. 60: 1415-1421.

GHENA, N. \& VIORIGA, C. 1970. Étude des virus X, Y, S \& M de la pomme de terre par différentes reactions sérologiques. Ann. Phytopath. 2: 365-377.

GOODING, G. V. \& BING, W. W. 1970. Serological identification of potato Y virus and tobacco etch viruses using immunodiffusion plates containing sodium dodecyl sulfate. Phytopath. 60: 1293.

GUGERLI, P. 1977. Untersuchungen über die grossräumige und lokale Verbreitung des Tabakrattlevirus (TRV) und seiner Vektoren in der Schweiz. Phytopath. Z. 89: 1-24.

- 1978. The detection of two potatoviruses by enzyme-linked immunosorbent assay (ELISA). Phytopath. Z. 92: 51-56.

- 1979. Potato virus A and potato leaf roll virus: purification, antiserum production and serological detection in potato and test plants by enzyme-linked immunosorbent assay (ELISA). Phytopath. Z. 96: 97-107.

GUNNINGHAM, I. C., TINSLEY, T. W. \& WALKER, I. M. 1966. Haemagglutination with plant and insect viruses. J. Gen. Microbiol. 42: 397-401.

GOUDSWAARD, J., DONK, J. A. van der, NOORDZIJ, A., VAN DAM, R. H. \& VAERMAN, J-P. 1978. Protein A reactivity of various mammalian immunoglobulins. Scand. J. Immunology 8: 21-28.

HAMILTON, R. I. 1964. Serodiacnosis of barley stripe mosaic facilitated by detergent. Phytopath. 54: $1290-1291$.

HARRISON, B. D. 1966. Further studies on a British form of pea early-browning virus. Ann. Appl. Biol. 57: $121-129$.

- 1970. Tobacco rattle virus. C.M.I./A.A.B. Descr. Pl. Viruses No 12.

-, FINCH, J. T., GIBBS, A. J., HOLLINGS, M., SHEPHERD, R. J., VALENTA, V. \& WETTER, C. 1971. Sixteen groups of plant viruses. Virology 45: 356-363.

\& JONES, R. A. C. 1970. Host range and some properties of potato mop-top virus. Ann. Appl. Biol. 65: 393-402.

- \& NIXON, H. L. 1959. Separation and properties of particles of tobacco rattle virus with different lengths. J. Gen. Microbiol. 21: 569-581.

— \& ROBINSON, D. J. 1978. The tobraviruses. Adv. Virus Res. 23: 25-77.

- \& ROBINSON, D. J. 1982. Detection and diagnosis of NM strains of tobacco rattle virus in potato. Abstr. Pap. A.A.B. Meet. Dundee 23rd-26th August, 1982. p. 43.

- \& WOODS, R. D. 1966. Serotypes and particle dimensions of tobacco rattle viruses from Europe and America. Virology 28: 610-620.

HEPP, R. F. \& ZOETEN, G. A. de 1978. Purification of potato leafroll virus and an evaluation of methods for its diagnosis. Am. Potato J. 55: 125-139.

HIRUKI, C. 1970. Red Kidney Bean, a useful bioassay host for qualitative and quantitative work with potato virus M. Phytopath. 60: 739-740.

HOOF, H. A. van 1968. Transmission of tobacco rattle virus by Trichodorus species. Nematologica 14: 20-24. 
- 1980. Aphid vectors of potato virus $Y^{\mathrm{n}}$. Neth. J. Pl. Path. 86: 159-162.

HORVÁTH, J. 1964. Ergebnisse der Identifizierung von mechanisch übertragbare Kartoffelviren an Testpflanzen mit besonderer Rücksicht auf Vergleichsuntersuchungen. Acta Agron. Hungary 13: 103-135.

- 1972. A burgonya M-virus (potato virus M) kimutatásának lehetösége különbösö babfajtákon. (Identification of potato virus $\mathrm{M}$ in various bean varieties.) Növénytermeles 21: 303-308.

— \& BOKX, J. A. de 1972. Über die Anfälligkeit von Chenopodium-Arten und -Varietäten gegen das M-Virus (potato virus M). Phytopath. Z. 73: 171-177.

HUNNIUS, W. 1976. Zum Problem der Interferenzen zwischen verschiedenen Virusarten der Kartoffel. Bayer. Landw. J.buch 53: 525-564.

HUOKUNA, V. 1962. Tervettä siemenperunaa paikalliskokeisiin ja kantasiementiloille. Koetoim. ja Käyt. 19: 41.

HUTTINGA, H. 1973. Properties of viruses of the potyvirus group. I. A simple method to purify bean yellow mosaic virus, pea mosaic virus, lettuce mosaic virus and potato virus $\mathrm{Y}^{\mathrm{n}}$. Neth. J. PI. Path. 79: $125-129$.

IGEL, M. \& LANGE, H. 1953. Verfahren zur Frühdiagnose von Viruskrankheiten bei Pflanzen. Patentanmeldung Deutsches Patentamt (Bundesrepublik Deutschland) Klasse 42 I Gruppe 1304, I $7145 \mathrm{IXb} / 421$ com 18. 4. 1953.

JAMALAINEN, E. A. 1946. The significance of potato virus diseases in Finland. Maatal.tiet. Aikak. 18: $134-146$.

JOHNSON, G. D., HOLBOROW, E. J. \& DORLING, J. 1978. Immunofluorescence and immunoenzyme techniques. Handb. Exp. Immunology 15: 1-30.

JOHNSON, J. 1936. Tobacco streak, a virus disease. Phytopath. 26: 285-292.

JONES, A. T. \& YOUNG, B. R. 1978. Some properties of two isolates of tobacco rattle virus obtained from peony and narcissus plants in New Zealand. Pl. Dis. Rep. 62: 925-928.

KACZMAREK, U. 1976. (In Polish) Abstract: Symptoms of viruses S and M on cut leaves of test plants of the hybrid A-6 (Solanum demissum \& Aquila), Solanum demissum Lindl. and Solanum demissum Cock. Referativnyi Zhur. 12.55.1803 (1976). (Ref. Rev. Pl. Path. 56: 618).

KAHN, R. P. \& MONROE, R. L. 1963. Detection of the Tobacco Veinal Necrosis strain of potato virus $\mathrm{Y}$ in Solanum cardenasii and S. andigenum introduced into the United States. Phytopath. 53: $1356-1359$.

- \& MONROE, R. L. 1970. Datura metel as a virus indicator plant. Phytopath. 60: 1183-1185.

— , SCOTT, H. A., BOZICEVICH, J. \& VINCENT, M. M. 1967. Detection of potato viruses X, M and $\mathrm{S}$ in dormant tubers by bentonite flocculation test. Phytopath. 57: 61-65.

KASSANIS, B \& GOVIER, D. A. 1970. Potato aucuba mosaic virus. C.M.I./A.A.B. Descr. Pl. Viruses No 98.

KELLER, E. R. \& BÉRCES, S. 1966. Check-testing for virus Y and leafroll in seed potatoes with particular reference to methods of increasing precision with A6-leaf test for virus Y. Eur. Potato J. 9: $1-14$.

KENNEDY, J. S., DAY, M. F. \& EASTOP, V. F. 1962. A conspectus of aphids as vectors of plant viruses. Commonw. Inst. Ent. London. 114 p.

KHAN, M. A. \& SLACK, S. A. 1978. Studies on the sensitivity of a latex agglutination test for the serological detection of potato virus $\mathrm{S}$ and potato virus $\mathrm{X}$ in Wisconsin. Am. Potato J. 55: 627-637.

KIRKPATRICK, H. C. \& ROSS, A. F. 1952. Aphid-transmission of potato leafroll virus to solanaceous species. Phytopath. 42: 540-546.

KLINKOWSKI, M. 1951. Ein Beitrag zur Frage der Infektionsmöglichkeit des X-Virus der Kartoffel bei Wurzelkontakt. Z. Pfl.krankh. Pfl.schutz 58: 3-6.

— \& SCHMELZER, K. 1957. Beiträge zur Kenntnis des virus der Tabak-Rippenbräune. Phytopath. Z. 28: 285-306.

- \& SCHMELZER, K. 1960. A necrotic type of potato virus Y. Am. Potato J. 37: 221-228.

KOENIG, R. 1981. Indirect ELISA method for the broad specificity detection of plant viruses. J. Gen. Virol. 55: 53-62.

- \& BODE, O. 1978. Sensitive detection of Andean potato latent and Andean potato mottle viruses in potato tubers with the serological latex test. Phytopath. Z. 92: 275-280. 
KOJIMA, M., SHIKATA, E., SUGAWARA, M. \& MURAYAMA, D. 1969. Purification and electron microscopy of potato leafroll virus. Virology 39: 162-174.

KOSTIW, M. 1981. Blattläuse als Vektoren für Kartoffelviren. Kartoffelbau, Gelsenkirchen-Bayer 32: $161-162$.

KOWALSKA, A. 1978. Differences among isolates of potato virus $M$ and potato virus S. Phytopath. Z. 93: $227-240$.

— , SKRZECZKOWSKA, S. \& PAKOSINSKA, M. 1976. Przydaność pomidora odmiany Nevskij jako rośliny-gospodarza wirusa $\mathrm{S}$ ziemniaka. (The suitability of tomato variety Nevskij as a host plant of potato virus S.) Biul. Inst. Ziemniaka 18: 71-75.

— \& WAS, M. 1976. Detection of potato virus M and potato virus $S$ on test plants. Potato Res. 19: 131-139.

KRISTENSEN, R. H. 1955. Potato virus X, serological investigations and other diagnostic methods. Proc. 2nd Conf. Potato Virus Dis. Lisse-Wageningen. p. 26-29.

- 1962. Jordbårne plantevira. Tidskr. Planteavd. 66: 75-148.

KRYLOV, A. V. \& GNUTOVA, R. V. 1974. On the possibility of using passive agglutination and complement fixation methods for potato X, F, and Y virus diagnosis. Phytopath. Z. 79: 203-216.

KURPPA, A. 1981. Yllättääkö vanha virus? Pellervo 1981, 3: 26-27.

- , JONES, A. T., HARRISON, B. D. \& BAILESS, K. W. 1981. Properties of spinach yellow mottle, a distinctive strain of tobacco rattle virus. Ann. Appl. Biol. 98: 243-254.

KURPPA, S. 1982. Peltokasvien juuriankeroiset. Koetoim. ja Käyt. 40: 60.

KÖHLER, E. 1953. Der Solanum demissum Bastard 'A6' als Testpflanze verschiedener Mosaikviren. Züchter 23: 173-176.

- 1962. Über die unterschiedliche Temperaturempfindlichkeit von Typen und Stämmen des Kartoffel-X-Virus. Phytopath. Z. 44: 189-199.

LADEBURG, R. C., LARSON, R. H. \& WALKER, J. C. 1950. Origin, interrelation and properties of ringspot strains of virus $\mathrm{X}$ in American potato varieties. Wis. Agric. Exp. Sta. Res. Bull. 165. 47 p.

LANGENBERG, W. G. \& BALL, E. M. 1972. High pH-ammonia agar immunodiffusion for plant viruses. Phytopath. 62: 1214-1217.

LARSON, R. H. 1943. A foliar mottle and necrosis in Chippewa potatoes associated with infection by a strain of the potato X virus. Phytopath. 33: 1216-1217.

LEISER, R-M. \& RICHTER, J. 1978. Reinigung und einige Eigenschaften des Kartoffel-Y-Virus. Arch. Phytopath. Pfl.schutz. 14: 337-350.

LISTER, R. M. \& BRACKER, C. E. 1969. Defectiveness and depence in three related strains of tobacco rattle virus. Virology 37: 262-275.

- \& ROCHOW, W. F. 1979. Detection of barley yellow dwarf virus by enzyme-linked immunosorbent assay. Phytopath. 69: 1393-1400.

LINDSTEN, K. 1981. Differentiering av virus inom potatisvirus Y-gruppen. Nord. Jordbr. Forskn. 63: 578-579.

LIU, H.-Y. \& DUFFUS, J. 1982. The differentiation of distinct serotypes from potato leaf roll affected plants by enzyme-linked immunosorbent assay (ELISA). Am. Potato J. 59: 476.

MAAT, D. Z. \& MIERZWA, Z. 1975. Potato virus A: Purification and antiserum preparation. Potato Res. 18: $126-129$.

- \& BOKX, J. A. de 1978. Potato leafroll virus: antiserum preparation and detection in potato leaves and sprouts with the enzyme-linked immunosorbent assay (ELISA). Neth. J. Pl. Path. 84: 149-156.

- \& BOKX, J. A. de 1978. Enzyme-linked immunosorbent assay (ELISA) for the detection of potato viruses $A$ and $Y$ in potato leaves and sprouts. Neth. J. Pl. Path. 84: 167-173.

MacCARTHY, H. R. 1954. Aphid transmission of potato leafroll virus. Phytopath. 44: 167-174.

MacKINNON, J. P. 1974. Detection, spread, and aphid transmission of potato virus S. Can. J. Bot. 52: 461-465.

MacLAGHLAN, D. S., LARSON, R. H. \& WALKER, J. C. 1953. Strain interrelationships in potato virus A. Wis. Agric. Exp. Sta. Res. Bull. 180. 36 p.

MANCINI, G., VAERMAN, J. P., CARBONARA, A. O. \& HEREMANS, J. F. 1964. A single radialdiffusion method for the immunological quantitation of proteins. Protides of the Biological Fluids. Elsevier, New York-Amsterdam. p. 370-373.

MANZER, F. E., MERRIAM, D. C. \& HELPER, D. R. 1978. Effects of potato virus S and two strains of 
potato virus X on yield of Russet Burbank, Kennebec and Katahdin cultivars in Maine. Am. Potato J. 55: 601-609.

— , MERRIAM, D. C. \& HELPER, P. R. 1979. Effect of potato virus S and mild potato virus X on early and late harvest yields of the Kennebec cultivar in Maine. Am. Potato J. 56: 435-439.

MARCO, S. 1981. A comparison of some methods for detecting potato leaf roll virus in potato tubers in Israel. Potato Res. 24: 11-19.

MATTHEWS, R. E. F. 1949. Studies on potato virus X. I. Types of change in potato virus X infectios. II. Criteria of relationships between strains. Ann. Appl. Biol. 36: 448-474.

MUNRO, J. 1955. The reactions of certain Solanaceous species to strains of potato virus Y. Can. J. Bot. 33: 355-361.

MURAYAMA, D. \& KOJIMA, M. 1974. Antigenicity of potato leafroll virus. Proc. Japan Acad. 50: 322-327.

- , KOJIMA, M. \& TAMADA, T. 1973. Purification and serology of two aphid-borne circulative viruses. 2nd Intern. Gongr. Pl. Path., Univ. Minn., Minneapolis. Abstr. Pap. 0092.

MURPHY, P. A. \& McKAY, R. 1929. The insect vectors of the leaf-roll disease of the potato. R. Dublin Soc. Sci. Proc. 19: 341-353.

- \& McKAY, R. 1932. A comparison of some European and American virus diseases of the potato. R. Dublin Soc. Sci. Proc. 20: 347-358.

NATTI, J. J., KIRKPATRICK, H. C. R. \& ROSS, A. F. 1953. Host range of potato leafroll virus. Am. Potato J. 30: 55-64.

NIENHAUS, F. \& STILLE, B. 1965. Übertragung des Kartoffel-X-Virus durch Zoosporen von Synchytrium endobioticum. Phytopath. Z. 54: 334-337.

NOORDAM, D. 1973. Identification of plant viruses, methods \& experiments. 205 p. Pudoc, Wageningen.

O'BRIEN, M. J. \& RICH, A. E. 1976. Potato Diseases. Agric. Handb. No 474, U.S.A. Dep. Agric./ Agric. Res Service. Wash. D. C. 79 p.

PETERS, D. 1967. The purification of potato leafroll virus from its vector Myzus persicae. Virology 31: 46-54.

- 1970. Potato leafroll virus. C.M.I./A.A.B. Descr. Pl. Viruses No 36.

POHJANHEIMO, O. 1961. Piilevinä esiintyvistä virustaudeista perunalajikkeissa. Maatal. ja Koetoim. 15: 242-249.

- 1962. Jaakko-perunalajike virustautien esiintymisen ja leviämisen ilmaisijana. Maatal. ja Koetoim. 16: $153-158$.

POHJAKALLIO, O., KARHUVAARA, L. \& ANTILA, S. 1961. The effect of potato rugose on the yield of some potato varieties. Maatal.tiet. Aikak. 33: 89-100.

PROLL, E., AHRENS, E. \& RICHTER, J. 1978. Ein Beitrag von Isolaten des Kartoffel-Virus M. Arch. Phytopath. Pfl.schutz 14: 209-217.

— , LEISER, R-M., OSTERMANN, W-D. \& SPAAR, D. 1981. Einige physiko-chemische Eingenschaften des Kartoffelvirus M. Potato Res. 24: 1-10.

— \& RICHTER, J. 1979. Reinigung und einige Eigenschaften der Kartoffelviren M und S. Arch. Phytopath. Pfl.schutz 15: 233-245.

PURCIFULL, D. E. \& BATCHELOR, D. L. 1977. Immunodiffusion tests with sodium dodecyl sulfate (SDS)-treated plant viruses and plant viral inclusions. Fla. Agric. Exp. Sta. Bull. No 788.

- \& GOODING, G. V. 1970. Immunodiffusion tests for potato virus $\mathrm{Y}$ and tobacco etch viruses. Phytopath. 60: 1036-1039.

- \& SHEPHERD, R. J. 1964. Preparation of protein fragments of several rod-shaped plant viruses and their use in agar-gel diffusion tests. Phytopath. 54: 1102-1108.

QUANJER, H. M. 1913. Die Negrose des Phloems der Kartoffelpflanze, die Ursache der Blattrollkrankheit. Meded. Landbouwhogesch. Wageningen 6: 41-80.

- 1943. Bijdrage tot de kennis van de in Nederland voor-komende ziekten van tabak en van de tabakstult op kleigrond. Tijdschr. Pl.ziekten 49: 37-51.

QUERFURTH, G. \& PAUL, H. L. 1979. Protein A-coated latex-linked antisera (PALLAS): new reagents for a sensitive test permitting the use of antisera unsuitable for the latex test. Phytopath. Z. 94: 282-285.

REESTMAN, A. J. 1970. Importance of the degree of virus infection for the production of ware potatoes. Potato Res. 13: 248-268. 
REGENMORTEL, M. H. V. van 1966. Plant virus serology. Adv. Virus Res. 12: 207-271.

— \& BURCKARD, J. 1980. Detection of a wide spectrum of tobacco mosaic virus strains by indirect enzyme-linked immunosorbent assays (ELISA). Virology 106: 327-334.

RICHARDSON, D. E. 1958. Some observations on the tobacco veinal necrosis strain of potato virus Y. Pl. Path. 7: 133-135.

RICHTER, J., AUGUSTIN, W. \& KLEINHEMPEL, H. 1977. Nachweis des Kartoffel S-Virus mit Hilfe des ELISA-Testes. Arch. Phytopath. Pfl.schutz 13: 289-292.

- , HAACK, I. \& EISENBRANDT, K. 1979. Routinemässige Serodiagnose der Kartoffelviren X, S, M und Y mit dem Radialimmundiffusionstest. Arch. Phytopath. Pfl.schuzt 15: 81-88.

— , LEISER, R.-M., PROLL, E. \& DÖRING, U. 1979. Versuche zur Differenzierung von Stämmen der Kartoffelviren X, S, M und Y an Hand ihrer Immunogenität. Arch. Phytopath. Pfl.schutz 15: 13-20.

ROBERT, Y. 1971. Epidémilogie de l'Enroulement de la Pomme de terre: capacité vectrice de stades et de formes des pucerons Aulacorthum solani Kltb, Macrosiphum euphorbiae Thomas et Myzus persicae Sulz. Potato Res. 14: 130-139.

- \& MAURY, Y. 1970. Capacités vectrices comparées de plusieurs souches de Myzus persicae Sulz., Aulacorthum solani Kltb. et Macrosiphum euphorbiae Thomas dans l'étude de la transmission de l'enroulement de la Pomme de terre. Potato Res. 13: 199-209.

ROBERTS, I. M., TAMADA, T. \& HARRISON, B. D. 1979. Relationship of potato leafroll to luteoviruses: evidence from electron microscope serological tests. J. Gen. Virol. 47: 209-213.

- \& HARRISON, B. D. 1979. Detection of potato leafroll and potato mop-top viruses by immunosorbent electron microscopy. Ann. Appl. Biol. 93: 289-297.

ROSS, H. 1968. Lycopersicum chilense Dun., eine Testpflanze für die beiden Kartoffelviren M und S. Eur. Potato J. 11: 281-286.

ROZENDAAL, A. 1952. Nieuwe virusproblemen bij de aardapple. Meded. Nederl. Alg. Keurd. Landbzaken Aardappelpootg. 8: 94-98.

- \& SLOGTEREN, D. H. M. van 1958. A potato virus identified with potato virus $\mathrm{M}$ and its relationship with potato virus S. Proc. 3rd Conf. Potato Virus Dis., Lisse-Wageningen. p. 20-36.

ROWHANI, A. \& STACE-SMITH, R. 1979. Purification and characterization of potato leafroll virus. Virology 98: 45-54.

SAITO, Y. \& IWATA, Y. 1964. Haemagglutination test of titration plant viruses. Virology 22: 426-428.

SALAMAN, R. N. 1938. The potato virus "X". Its strains and reactions. Philos. Trans. B. 229: 137-217.

SARKAR, S. 1975. A rapid electron microscopic diagnosis of potato leafroll virus. Potato Res. 18: 227-236.

SCHMELZER, K. 1957. Untersuchungen über den Wirtspflanzenkreis des Tabakmauche-Virus. Phytopath. Z. 30: 281-314.

- 1967. Wirte des Kartoffel-Y- und des Tabakätzmosaik-Virus ausserhalb der Solanaceen. Phytopath. Z. 60: 301-315.

SCHULTZ, E. S. \& FOLSOM, D. 1923. Transmission, variation and control of certain degeneration disases of potatoes. J. Agric. Res. (US) 25: 43-117.

SCOTT, H. A., BOZICEVICH, J. \& VINCENT, M. M. 1963. Bentonite flocculation: a rapid sensitive serological test for the detection of plant virus antigens. Phytopath. 53: 889.

SEPPÄNEN, E. 1963. Huomiota perunan virustauteihin. Koetoim. ja Käyt. 20: 22.

- 1972. Perunan virustautien esiintyminen Suomessa 1964-1966. Ann. Agric. Fenn. 11: 407-416.

- 1974. Ajankohtaista perunan siemenkysymyksestä. Koetoim. ja Käyt. 31: 32.

— \& HYTÖNEN, T. 1977. Siemenperunan tuonti kasvukaudeksi 1975. Kasvitautien tutkimuslaitoksen tiedote No 29. Maatalouden tutkimuskeskus Vantaa. 11 p.

SHEPARD, J. F. 1970a. The potential significance of potato haemagglutins (Lectins) in serodiagnosis. Phytopath. 60: 1623-1625.

- 1970b. A radial-immunodiffusion test for the simultanous diagnosis of potato viruses $\mathrm{S}$ and $\mathrm{X}$. Phytopath. 60: 1669-1671.

- 1972. Gel-diffusion methods for the serological detection of potato viruses X, S and M. Mont. Agric. Exp. Sta. Bull. 622. 72 p.

- , JUTILA, J. W., CATLIN, J. E. \& NEWMAN, F. S. 1971. Immunodiffusion assay for potato virus $\mathrm{M}$ infection. Phytopath. 61: 873-874. 
- \& SECOR, G. A. 1969. Detection of potato virus $\mathrm{X}$ in infected plant tissue by radial and doublediffusion tests in agar. Phytopath. 59: 1838-1844.

- , SECOR, G. A. \& PURCIFULL, D. E. 1974. Immunochemical crossreactivity between the dissociated capsid proteins of PVY group plant viruses. Virology 58: 464-475.

SHEPHERD, R. J. \& POUND, G. S. 1960. Purification of turnip mosaic virus. Phytopath. 50: 797-803.

SINGH, R. P. \& McDONALD, J. G. 1981. Purification of potato virus A and its detection in potato by enzyme-linked immunosorbent assay (ELISA). Am. Potato J. 58: 181-190.

SLOGTEREN, D. H. M. van 1955. Serological micro-reactions with plant viruses under paraffin oil. Proc. 2nd Conf. Potato Virus Dis., Lisse-Wageningen. p. 51-54.

- \& SLOGTEREN, D. H. M. van 1957. Serological identification of plant viruses and serological diagnosis of virus diseases of plants. Ann. Rev. Microbiol. 11: 149-164.

SMITH, K. M. 1931. On the composite nature of certain potato virus diseases of the mosaic group as revealed by the use of plant indicators, and selective methods of transmission. R. Soc. Lond. Proc. Ser. B. 109: 215-267.

- 1937. A textbook of plant virus diseases. 615 p. J. \& A. Churchill Ltd, London.

- 1957. A textbook of plant viruses. 2nd ed. 652 p. Boston.

- \& DENNIS, R. W. G. 1940. Some notes on a suspected variant of Solanum virus 2. (potato virus Y). Ann. Appl. Biol. 27: 65-70.

SOINI, E. \& HEMMILÄ, I. 1979. Fluoroimmunoassay: Present status and key problems. Clin. Chem. 25: $353-361$.

SOL, H. H. \& SEINHORST, J. W. 1961. The transmission of rattle virus by Trichodorus pachydermus. Tijdschr. Pl.ziekten 67: 307-309.

SPRAU, F. 1957. Untersuchungen über die Ausbreitung der Blattrollvirus in der Kartoffelpflanze mit Hilfe eines Färbetestes. Proc. 3rd Conf. Potato Virus Dis., Lisse-Wageningen. p. 71-79.

STACE-SMITH, R. \& TREMAINE, J. H. 1970. Purification and composition of potato virus Y. Phytopath. 60: $1785-1789$.

STASZEWICZ, M. 1977. Treatments that improve serological detection of potato viruses X, S, M and Y. Potato Res. 20: 89-93.

- \& SWINIARSKI, E. 1975. Influence of some chemical compounds on serological detection of potato viruses X, S, M and Y. Potato Res. 18: 148.

SYNAK, Z. 1975. Wplyw temperatury i czasu ogrwewania bulw ziemniaka na stopien wykrywalnosci wirusow X, S, M w czesciach przystolonowych. [Effect of temperature and warming up time of potato tubers on the detection of viruses X, S, M in near-stolon parts of tubers.] Rocz. Nauk Polniczych 101: 33-46. (Ref. Rev. Pl. Path. 56: 817).

TAKANAMI, Y. \& KUBO, S. 1979. Enzyme-assisted purification of two phloem limited viruses: tobacco necrotic dwarf and potato leafroll. J. Gen. Virol. 44: 153-159.

TALLEY, J., WARREN, F. H. J. B., TORRANCE, L. \& JONES, R. A. C. 1980. A simple kit for detection of plant viruses by the latex serological test. Pl. Path. 29: 77-79.

TAMADA, T. \& HARRISON, B. D. 1980. Application of enzyme-linked immunosorbent assay to the detection of potato leafroll virus in potato tubers. Ann. Appl. Biol. 96: 67-78.

TAPIO, E. 1972a. Virus-free clones on the potato varieties Pito and Tammiston Aikainen. Ann. Agric. Fenn. 11: 115-118.

-1972 b. The appearence of soil-borne viruses in Finnish plant nurseries. J. Sci. Agric. Soc. Finl. 44: 83-91.

TAYLOR, C. E. \& CADMAN, C. H. 1969. Nematode vectors. Viruses, vectors and vegetation. 666 p. Interscience, New York.

THORNBERRY, H. H. 1966. Plant pests of importance to North American agriculture. Index of plant virus diseases. Agric. Handb. U.S.D.A. 307. 446 p.

TOMLISON, J. A. \& WALKEY, D. G. A. 1967. Effects of ultrasonic treatment on turnip mosaic virus and potato virus X. Virology 32: 267-278.

TORRANCE, L. 1980a. Use of protein A to improve sensitisation of latex particles with antibodies to plant viruses. Ann. Appl. Biol. 96: 45-50.

- 1980b. Use of bovine Clq to detect plant viruses in an enzyme-linked immunosorbent-type assay. J. Gen. Virol. 51: 229-232.

- \& JONES, R. A. C. 1981. Recent developments in serological methods suited for use in routine testing for plant viruses. Pl. Path. 30: 1-24. 
- \& JONES, R. A. C. 1982. Increased sensitivity of detection of plant viruses obtained by using a fluorogenic substrate in enzyme-linked immunosorbent assay. Ann. Appl. Biol. 101: 501-509.

TROFIMETS, L. N., EGOROVA, L. I. \& ZHURALEVA, V. A. 1967. Novoe v diagnostike virusa Y Kartofelya. [New diagnosis of Potato virus Y]. Dok. Vsesoj. Akad. Sel'skoh. Nauk. 1967 (7): 26-27. (Ref. Rev. Appl. Mycol. 47: 407).

TUTHILL, G. S. \& DECKER, Ph. 1941. Losses in the yield caused by leafroll of potatoes. Am. Potato J. 18: $136-139$.

VARMA, J. P., CHAUBEY, I. P., UPRETI, G. C. \& NAGAICH, B. B. 1970. Three distinctive strains of potato virus X. Phytopath. Z. 67: 361-366.

VOLLER, A., BIDWELL, D. E. \& BARLETT, A. 1976. Enzyme immunoassays in dianostic medicine. Bull. WHO 53: 55-65.

- , BIDWELL, D. E., HULDT, G. \& ENGVALL, E. 1974. A microplate method of enzyme linked immunosorbent assay and its application to malaria. Bull. WHO 51: 209-211.

VULIČ, M. \& ARENZ, B. 1963. Die Nachweisbarkeit des Y-Virus in den verschiedenen Pflanzenteilen sekundär inifizierten Kartoffelpflanzen (Methodischer Vergleich von Serologie und A6-Test). Bayer. Landw. J.buch 40: 151-159.

— \& HUNNIUS, W. 1967. Die Reaktionen verschiedener Pflanzenarten auf Blattinfektionen mit Sund M-Virus der Kartoffel. Phytopath. Z. 59: 225-248.

WALTERS, H. J. 1952. Some relationships of three plant viruses to the differential grasshopper, Melanoplus differentialis (THOS.). Phytopath. 42: 355-362.

WEBB, R. E., LARSON, R. H. \& WALKER, J. C. 1952. Relationships of potato leaf roll virus strains. Wis. Agric. Exp. Sta. Res. Bull. 178: 1-40.

WEEMEN, B. K. van \& SCHURS, A. H. W. M. 1972. Immunoassay using hapten-enzyme conjugates. FEBS Letters 15: 77-81.

WEIDEMANN, H. L. von 1981. Über die Intensität der Symptomausbildung bei Kartoffelsorten nach Infektion mit Kartoffelvirus-Y-isolaten. Nachr.bl. Deut. Pfl.schutzd. 33: 177-180.

— \& KOENIG, R. 1979. Untersuchungen über neue Isolate des Kartoffel-Y-Virus. Gesunde Pfl. 31: 293-296.

WETTER, C. 1960. Partielle Reinigung einiger gestreckter Pflanzenviren und ihre Verwendung als Antigene bei der Immunisierung mittels Freundschem Adjuvans. Arch. Mikrobiol. 37: 278-292.

- 1971. Potato virus S. C.M.I./A.A.B. Descr. Pl. Viruses No 60.

- 1972. Potato virus M. C.M.I./A.A.B. Descr. Pl. Viruses No 87.

— \& BRANDES, J. 1956. Untersuchungen über das Kartoffel-S-Virus. Phytopath. Z. 26: 81-92.

— \& VÖLK, J. 1960. Versuche zur Übertragung der Kartoffel-Viren M und S durch Myzus persicae Sulz. Eur. Potato J. 3: 158-163.

WRIGHT, N. S. \& MacCARTHY, H. R. 1963. Expression and detection of leaf roll virus strains in potato. Am. Potato J. 40: 154-162.

YLLÖ, L. 1966. Siemenperunan terveyden merkitys. Koetoim. ja Käyt. 23: 7.

- 1975. Siemenperunan terveyden vaikutus satoon. Koetoim. ja Käyt. 32: 37.

ZAAG, D. E. van der 1977. Betekenis van infectie van poters met virus op de opbrengst bij aardappelen. (With a summary: Significance of infection of seed tubers with virus for yield of potatoes). Landbouwk. Tijdschr. 154-157.

ZAMBONI, S. S., McCRUM, R. C. \& MANZER, F. E. 1977. A comparison of the callose test to other methods for detection of potato leafroll virus infection. Am. Potato J. 54: 475-476. 


\title{
Suomessa esiintyvät perunavirukset ja niiden määrittäminen
}

\author{
Aarne Kurppa \\ Helsingin yliopiston kasvipatologian laitos
}

Tämän tutkimuksen tarkoituksena oli selvittää, mitä perunan tautiviruksia esiintyy maassamme, sekä erityisesti soveltaa tai kehittää menetelmiä niiden luotettavaksi määrittämiseksi. Viruksia eristettiin vuosina 1975-1982 kasvinjalostuslaitoksillamme ja siemenperunaviljelyssämme tuotetusta perunasta, maahan tuodusta siemenperunasta sekä eri puolilta maatamme viljelyksiltä tavatusta viroottisesta perunasta.

Serologisissa määrityksissä tarvitut virusantiseerumit valmistettiin virusrotututkimusten perusteella valituille isolaateille. Vertailuaineistona käytettiin myös ulkomaisia antiseerumeita sekä ELISA-menetelmässä myös valmisreagensseja.

Tutkimuksessa todettiin seuraavat 7 perunan virusta: perunan X-virus (PVX), perunan S-virus (PVS), perunan M-virus (PVM), perunan Y-virus (PVY), perunan A-virus (PVA), perunan kierrelehtisyysvirus (PLRV) sekä tupakan rattle virus (TRV).

Perunan X-viruksella todettiin kaksi päärotua, normaalirotu ja rengaslaikkurotu. Myös Y-viruksen päärotuja esiintyi kaksi, $\mathrm{Y}^{\circ}-\mathrm{ja}^{\mathrm{n}}{ }^{\mathrm{n}}$-rodut. Maan eteläosissa tavattiin molempia rotuja. Pohjanmaan siementuotantoalueella esiintyi lähinnä vain $\mathrm{Y}^{\mathrm{n}}$-rotua. Molemmissa roduissa todettiin lisäksi isolaattieroja. Muiden virusten biologiset ominaisuudet vaihtelivat vähemmän, eikä niiden isolaatteja luokiteltu eri rotuihin kuuluviksi.

Kaikki virukset ja virusisolaatit voitiin osoittaa ja osin myös tunnistaa testikasvioireiden perusteella. Joidenkin virusten ja virusisolaattien oireet testikasveissa poikkesivat olennaisesti julkaistuista.

Perunan X-, S-, M- ja Y-virukset olivat yleisiä luokitellussa siemenperunassa 1970-luvun puolivälissä, mutta erityisesti X-, S- ja M-virusten esiintyminen ja merkitys on vähentynyt sitä mukaa, kun tervettä perusaineistoa on saatu siemenperunan alkutuotantoon.

Taudinaiheuttajina Y-virus ja kierrelehtisyysvirus todettiin erittäin haitallisiksi kaikissa koelajikkeissa. Y-viruksen $\mathrm{Y}^{\circ}$-rotu esiintyi tappavana Ostara- ja Hankkijan Timo -lajikkeissa ja esti näissä sadonmuodostuksen lähes täysin. Rotu aiheutti useimmissa lajikkeissa nekroosioireita. $\mathrm{Y}^{\mathrm{n}}$-rotu aiheutti eri asteisia kurttu- ja mosaiikkioireita lajikkeesta rïppuen, mutta nekroosia ei esiintynyt. Perunan kierrelehtisyysvirus aiheutti primäärioireina latvaosista alkavaa lehtien kiertymistä, sekundäärioireet ilmestyivät ensimmäiseksi vanhoihin alalehtiin. Kierreoireiden lisäksi taudinkuvaan kuului antosyaanimuodostus useimmissa lajikkeissa. Sekundäärisen kierreviroosin todettiin alentavan yksilösatoa Siikli-lajikkeella 77 \%.

Myös M- ja A-virukset aiheuttivat eräissä lajikkeissa voimakkaan taudin. M-viruksen aiheuttamiin oireisiin kuului selvä kitukasvuisuus, pensastuminen sekä lehtien kiertyminen lusikkamaisiksi. Yksilösatoa virus saattoi alentaa noin $50 \%$. A-virus aiheutti kurttuisuutta, kloroosia sekä mosaiikkioireita. Muiden virusten aiheuttamat oireet olivat lieviä.

Kaikki kirvalevintäiset virukset levisivät infektiolähteistä herkästi, herkimmin leviävä oli Y-virus. S-virusisolaattien välillä esiintyi huomattavia levintäeroja. X-viruksen rengaslaikkurotu levisi kasvustossa normaalirotua herkemmin, vaikka sekin osoitettiin pelkästään mehulevintäiseksi. Perunalajikkeiden infektoitumisherkkyydessä todettiin huomattavia eroja. Useat lajikkeet olivat yhdenmukaisesti alttiita tai kestäviä S- ja M-viruksille.

Kaikki tutkitut virukset voitiin puhdistaa kasvimateriaalista käyttämällä julkaistuja menetelmiä tai niistä parannettuja muunnoksia. Suurimmat puhdistetut virussaaliit olivat: PVX 640 mg, PVS 31 mg, PVM 48 mg, PVY 26 mg, PVA 12 mg, TRV 85 mg ja PLRV $1.1 \mathrm{mg} /$ $\mathrm{kg}$ tuoreita tai pakastettuja lehtiä. X-, S-, M- ja Y-virusten isolaateille valmistettujen antiseerumien tiitterit olivat mikropresipitaatiomenetelmän avulla määritettynä $1 / 1024-1 / 8192$. Ulkomaiset antiseerumit reagoivat tutkittuihin antigeeneihin heikommin kuin itse valmistetut seerumit. Geelidiffuusiomenetelmiin soveltuvien, pilkotuilla X-, S- ja M-virusproteiineilla 
tuotettujen antiseerumien tiitterit olivat $1 / 128,1 / 32$ ja $1 / 64$ kaksoisdiffuusiomenetelmällä määritettynä.

Pienin kaksoisdiffuusiomenetelmän avulla määritetty virusproteiinikonsentraatio (PVX) oli $10 \mu \mathrm{g} / \mathrm{ml}$, yksivaihemenetelmällä vastaavasti $1 \mu \mathrm{g} / \mathrm{ml}$. Perunan lehtimehusta määritetyt laimennokset olivat $1 / 128$ ja $1 / 1024$. ELISA-menetelmän avulla määritetty alhaisin viruskonsentraatio (PVX) oli $0.1 \mathrm{ng} / \mathrm{ml}$. Perunan lehtimehusta PVX voitiin määrittää $10^{-6}-10^{-7}$ -laimennoksista, mikä vastaa viruksen laimennosrajaa infektiokokeissa. ELISA-testissä saatiin X- ja M-viroottisista kasvinäytteistä parhaimmillaan yli 100-kertainen, S-viroottisesta 94kertainen ja Y-viroottisesta 46-kertainen absorbanssiarvo vastaavaan terveeseen näytteeseen verrattaessa, kun mittauksen 0 -tasona käytettiin tuoreen substraatin antamaa absorbanssiarvoa.

Y-viruksen $\mathrm{Y}^{\circ}$ - ja $\mathrm{Y}^{\mathrm{n}}$-rotujen serologinen eroavuus osoittautui ELISA-testissä merkittäväksi, heterologisessa reaktiossa mitattu absorbanssiarvo vastasi kymmenkertaisesti laimennetusta homologisesta näytteestä saatua arvoa. Muiden virusten isolaattien väliset serologiset erot olivat määritysluotettavuuden kannalta merkityksettömän vähäisiä.

Agglutinaatio- ja A6-irtolehtimenetelmämäärityksissä todettiin runsaasti virheitä, joiden syynä oli menetelmien vähäinen herkkyys tai epäspesifisyys. Agglutinaatiotestin herkkyys ei riittänyt Y-viruksen määrittämiseen perunan lehtimehusta. A6-irtolehti reagoi Y-virusta muistuttavin oirein $\mathrm{X}$-viruksen rengaslaikkurotuun.

Kaksoisdiffuusiomenetelmä ei ollut riittävän herkkä perunavirusten rutiinimääritykseen, mutta yksivaihemenetelmän avulla saatiin sekundääri-infektoituneiden perunoiden lehtimehusta X-, S- ja M-viruksista luotettavat määritystulokset. Menetelmä ei kuitenkaan soveltunut rutiinikäyttöön.

ELISA-menetelmän avulla X-, S-, M- ja Y-virukset voitiin määrittää täysin luotettavasti perunan lehtimehusta ja lähes yhtä luotettavasti myös idätetystä mukulasta. Tulosten vastaavuus oli: PVX $100 \%$, PVM $97 \%$, PVS $92 \%$ ja PVY $90 \%$. Myös A-virus ja kierrelehtisyysvirus voitiin määrittää luotettavasti idätetystä mukulasta.

Primääri-infektoituneen itämättömän mukulan viruskonsentraatio saattaa olla nïn alhainen, ettei siitä saada luotettavaa määritystulosta. Mukulan vähäinen idättäminen kohottaa viruskonsentraatiota, jolloin virukset voidaan määrittää ELISA-testin avulla rïttävän luotettavasti idullisesta mukulan silmupalasta. 